\title{
Perceptual and Ergonomics Factors in Web Design as A Condition for Better Presentation of Companies
}

\author{
Filip Trajkovski
}

Faculty of Mechanical Engineering, Industrial Design, Ss. "Cyril and Methodius University" of Skopje, Skopje, Republic of Macedonia

Citation: Trajkovski F. [Perceptual and Ergonomics Factors in Web Design as A Condition for Better 10; $10038.1 \mathrm{MSc}$ [Macedonian] http://dx.doi.org/10.3889/seejad.2018.10038 Keywords: Perception; Ergonomics; Web design; Website; Web page; Technology transfer center; Promotion

Correspondence: Filip Trajkovski. Faculty of Mechanical Engineering, Industrial Design, Ss. "Cyril and Methodius University" of Skopje, Skopje, Republic of Macedonia. Email: fic_sk@t-home.mk

Received: 05-May-2018; Revised: 06-Jul-2018; Accepted: 07-Jul-2018; Published: 08-Jul-2018

Copyright: ๑ 2018 Filip Trajkovski. This is an openCoess article distributed under the terms of the Creative Commons Attribution License, which permits unrestricted use, distribution, and reproduction in any mediun
provided the original author and source are credited. Competing Interests: The author has declared that no competing interests exist

\section{Abstract}

The corporate identity represents a complete visual solution of the company by which it presents itself on the market and in the public in general. A big part of one company's success is the branding quality, marketing and visual presentation. With the emergence of the Internet, in the last decades, the design and development of a website became an inevitable part of the company's presentation. The main goal of this master work is to give contribution in the process of improvement of the corporate identity of the Center for Research, Development and Continuous Learning CIRKO DOOEL Skopje, with an emphasis on the presentation on the Internet. The leading idea for this master work is the creation of a modern and recognizable website for the company CIRKO DOOEL Skopje, rich with contents that will provide a quality presentation of all the sectors and activities which this company covers, and with that will improve its availability, visibility and rating on the market. The first impression that a user gets accessing a certain website is of a crucial significance. Because of that, during the creation of this master work particular attention is given to the research and analysis of the ergonomics and perceptual factors in web design, in order to correctly apply them in the specific tasks. Additionally, for the needs of this master work, researches are conducted to comprehend the requirements and needs of the users - to get a clear picture how to improve the user experience during the process of browsing the websites that are of interest and which is the most appropriate method that should be used to create a new more effective promotion. The basic objective in the promotion is familiarization of the users with the real capabilities of the Center for Research, Development and Continuous Learning. It's expected that the overall results of this master work will give contribution in the process of improvement of the corporate identity of CIRKO DOOEL Skopje, which will improve the public visibility, as well as the company's success in the business world. 


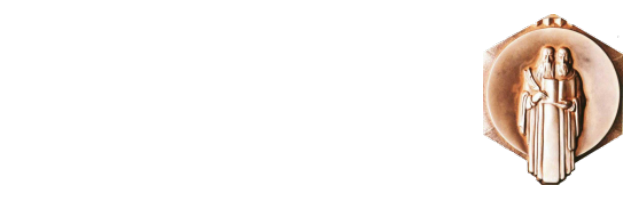

УНИВЕРЗИТЕТ „СВ. КИРИЛ И МЕТОДИЈ“ - СКОПЈЕ

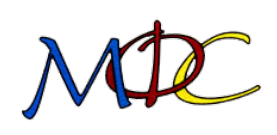

МАШИНСКИ ФАКУЛТЕТ - СКОПЈЕ

ПОСТДИПЛОМСКИ СТУДИИ ПО ИНДУСТРИСКИ ДИЗАЈН И МАРКЕТИНГ

ФИЛИП ТРАЈКОВСКИ

Перцептивните и ергономските фактори во веб дизајнот како услов за подобро претставување на компаниите

МАГИСТЕРСКА РАБОТА

CКОПJЕ, 2015 

Ментор:

Членови на комисијата:

Машински Факултет - Скопје

Проф. д-р Милан Ќосевски

Машински Факултет - Скопје

Дата на промоција:

Проф. д-р Татјана Кандикјан

Проф. д-р Софија Сидоренко

Машински Факултет - Скопје (ментор)

\section{Дата на одбрана:}


ФИЛИП ТРАЈКОВСКИ, дипл. инЖ. по индустриски дизајн

\author{
Перцептивните и ергономските фактори во веб дизајнот како услов за подобро \\ претставување на компаниите
}

\title{
АПСТРАКТ:
}

Корпоративниот идентитет претставува комплетно визуелно решение на компанијата со кое таа се претставува на пазарот и воопшто во јавноста. Голема заслуга за успехот на една компанија е нејзиното квалитетно брендирање, маркетиншко и визуелно претставување. Последниве децении, со појавата на Интернетот, неизоставен дел од претставувањето на компаниите е изработката на веб локации. Главна цел на оваа магистерска работа е да се даде придонес во унапредувањето на корпоративниот идентитет на Центарот за истражувања, развој и континуирано образование ЦИРКО ДООЕЛ Скопје, со нагласок на презентирањето преку Интернет. Водечка идеја за оваа магистерска работа е да се направи модерна и препознатлива веб локација за компанијата цИРКО ДООЕЛ Скопје, богата со содржини што ќе обезбеди квалитетна презентација на сите сектори и дејности кои ги покрива оваа компанија, а со тоа да се подобри нејзината достапност, видливост и рејтинг на пазарот. Од исклучителна важност е првиот впечаток кој се добива кога ќе се пристапи на одредена веб локација. Затоа, при изработката на оваа магистерска работа особено внимание е посветено на проучување на ергономските и перцептивните фактори во веб дизајнот, со цел правилно да се применат во конкретните задачи. Дополнително, за потребите на магистерската работа, спроведени се истражувања за да се осознаат барањата и потребите на корисниците - за да се добие појасна претстава како да се подобри корисничкото искуство при прегледувањето на веб локациите кои се од интерес и кој е најсоодветниот метод кој треба да се примени за да се создаде нова поефективна промоција. При промовирањето основна цел е запознавање на корисниците со вистинските можности на Центарот за истражувања, развој и континуирано образование. Се очекува целокупните резултати од оваа магистерска тема да дадат придонес во унапредувањето на корпоративниот идентитет на ЦИРКО ДООЕЛ Скопје, со што ќе се подобри нејзината видливост во јавноста и во деловниот свет во областа која ја покрива, а со тоа и успешноста во работата на компанијата.

клУчни ЗБОРОВИ: перцепција, ергономија, веб дизајн, веб локација, веб страница, центар за трансфер на технологија, промоција 
Perceptual and ergonomics factors in web design as a condition for better presentation of companies

\section{ABSTRACT:}

The corporate identity represents a complete visual solution of the company by which it presents itself on the market and in the public in general. A big part of one company's success is the branding quality, marketing and visual presentation. With the emergence of the Internet, in the last decades, the design and development of a website became an inevitable part of the company's presentation. The main goal of this master's work is to give contribution in the process of improvement of the corporate identity of the Center for Research, Development and Continuous Learning CIRKO DOOEL Skopje, with an emphasis on the presentation on the Internet. The leading idea for this master's work is the creation of a modern and recognizable website for the company CIRKO DOOEL Skopje, rich with contents that will provide a quality presentation of all the sectors and activities which this company covers, and with that improve its availability, visibility and rating on the market. The first impression that a user gets when he/she accesses a certain website is of crucial significance. Because of that, during the creation of this master work particular attention is given to the research and analysis of the ergonomics and perceptual factors in web design, in order to correctly apply them in the specific tasks. Additionally, for the needs of this master work, researches are conducted to comprehend the requirements and needs of the users - to get a clear picture how to improve the user experience during the process of browsing the websites that are of interest and which is the most appropriate method that should be used to create a new more effective promotion. The basic objective in the promotion is familiarization of the users with the real capabilities of the Center for Research, Development and Continuous Learning. It's expected that the overall results of this master work will give contribution in the process of improvement of the corporate identity of CIRKO DOOEL Skopje, which will improve the public visibility, as well as the company's success in the business world.

KEY WORDS: perception, ergonomics, web design, website, web page, technology transfer center, promotion 


\section{СОДРЖИНА}

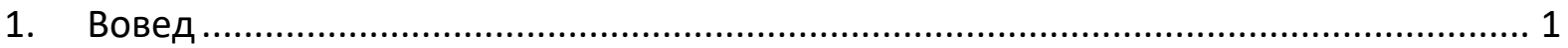

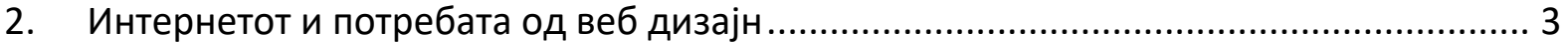

2.1. Постапки при креирање веб локација .......................................................... 5

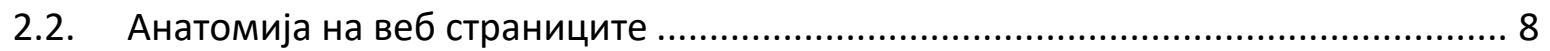

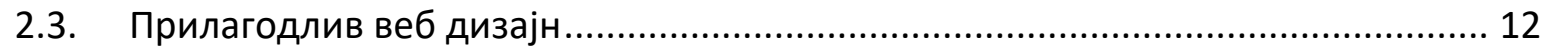

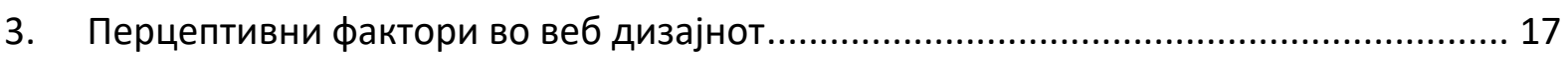

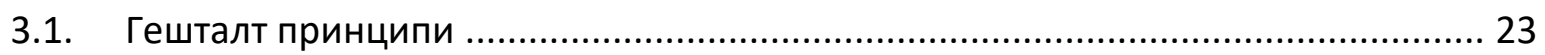

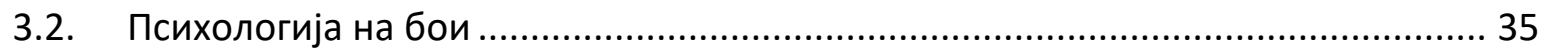

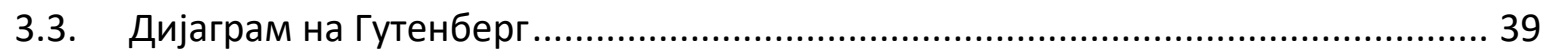

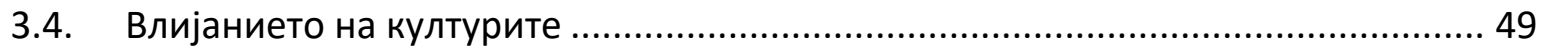

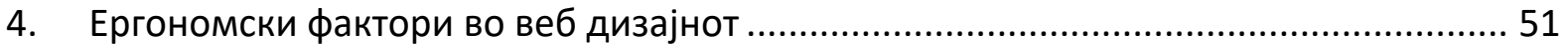

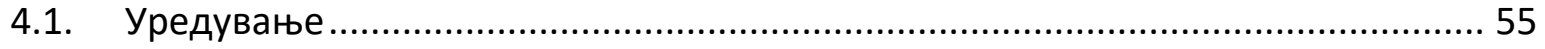

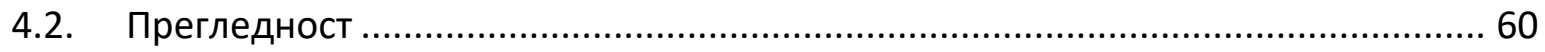

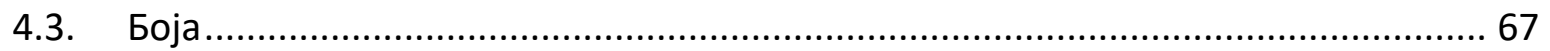

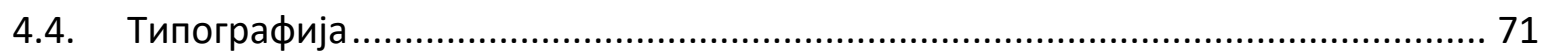

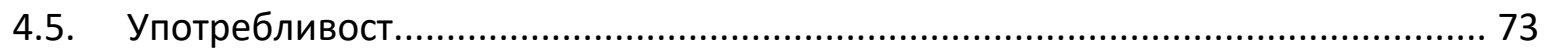

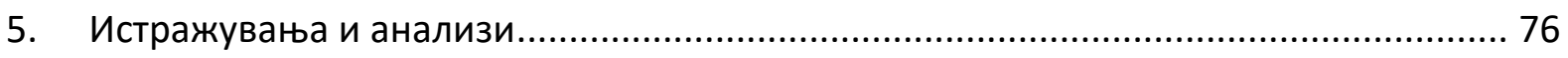

5.1. Анализа на статистички податоци од одбрани организации ширум светот.... 77

5.2. Анализа на статистички податоци од Државниот завод за статистика на РМ.. 82

5.3. Истражување на мислењето на корисниците ................................................ 87

5.4. Анализа на актуелните трендови во веб дизајнот ......................................... 97

5.5. Анализа на конкурентски веб локации ...................................................... 107

6. Дефинирање на конкретна задача - дизајн на веб локација и промотивен материјал за компанијата ЦИРКО ДООЕЛ Скопје ...................................................... 114 
6.1. Хронологија на развојот на корпоративниот идентитет на ЦИРКО ДООЕЛ Скопје

6.2. Структура на веб локацијата за компанијата цИРКО ДООЕЛ Скопје.....

6.3. Дефинирање на потребите и барањата кои се очекува да ги исполни веб локацијата на ЦИРКО ДООЕЛ Скопје..... 134

6.4. Предлог концепти за веб локацијата за компанијата ЦИРКО ДООЕЛ Скопје. 136

7. Презентација на конечниот дизајн на веб локацијата и промотивниот материјал за ЦИРКО ДООЕЛ Скопје 140

7.1. Избран концепт за веб локацијата за компанијата ЦИРКО дООЕЛ Скопје ..... 140

7.2. Предлог концепти за промотивниот материјал за компанијата ЦИРКО ДООЕЛ Скопје 147

8. Заклучок . 155

9. Користена литература 156 


\section{1. Вовед}

Корпоративниот идентитет претставува комплетно визуелно решение на компанијата со кое таа се претставува на пазарот и воопшто во јавноста. Основна карактеристика на корпоративниот идентитет е единствен стил кој се препознава во секој негов елемент. Еден од главните елементи на визуелниот идентитет е логото кое станува заштитен знак, симбол на компанијата и се појавува во сите видови графичка презентација, почнувајќи од меморандуми, фактури, визит карти, памфлети, летоци, каталози, на самите производи, на опаковките на производите, па дури и во дизајнот на веб страниците на компанијата.

Визуелниот идентитет е основно средство за распознавање на сите визуелни физички карактеристики на еден производ, услуга, идеја или компанија со кои тие се разликуваат од останатите и кои им овозможуваат на компаниите да ја стекнат, унапредат или задржат предноста пред конкуренцијата. Визуелноста не е маска која се става за да бидат задоволени очекувањата на општеството, туку претставува целовитост на комплетната компанија која се забележува на сите нивоа.

Токму затоа, голема заслуга за успехот на една компанија е нејзиното квалитетно брендирање, маркетиншко и визуелно претставување. Последниве децении, со појавата на Интернетот, неизоставен дел од претставувањето на компаниите е изработката на веб локации. Брзиот пренос на информации е од исклучително значење во деловната комуникација и токму од него зависи успехот на многу деловни активности. Наоѓањето соодветно, брзо и ефикасно средство за пренос на информациите отсекогаш претставувало една од поважните цели на човековите научни и технолошки истражувања. Со развивањето на информатичката технологија и појавата на Интернетот тој стана средство за комуникација без кое модерното општество не може да се замисли. Споредено со печатените медиуми, Интернетот овозможува децентрализација на содржините. Имено, пристап до Интернет може да се оствари скоро секаде и тоа на најразлични начини, вклучувајќи ги и преносливите уреди како што се: таблет компјутерите, мобилните телефони, мултимедијалните уреди, играчките конзоли итн. Ова значи дека им е овозможено на поединци, деловни 
корисници и организации да испратат информации на поголема група луѓе, со далеку помали трошоци и практично без изгубено време за доставување.

Главна цел на оваа магистерска работа е да се даде придонес во унапредувањето на корпоративниот идентитет на Центарот за истражувања, развој и континуирано образование ЦИРКО ДООЕЛ Скопје, со нагласок на презентирањето преку Интернет. Идејата за оваа тема е иницирана од раководниот кадар на Центарот кој бележи постојан развој во повеќе насоки и со голем број услужни дејности.

Центарот за истражувања, развој и континуирано образование ЦИРКО ДООЕЛ Скопје работи во рамките на Универзитетот “Св. Кирил и Методиј”. Од неговото формирање до денес ЦИРКО има реализирано бројни проекти на полето на експертизи за мали и средни компании, обуки од типот доживотно учење, обуки за обезбедување пристап до нови технологии, обуки за компаниите заради подобрување на нивните можности, зголемување на продуктивноста и унапредување на производните процеси итн. ЦИРКО е организиран во неколку сектори: сектор за возила, сектор за почисто производство, сектор за индустриски дизајн, сектор за заштита при работа и други. Сите сектори се поддржани од академскиот и истражувачкиот потенцијал на Машинскиот факултет во Скопје, на база на взаемни договори. 


\section{2. Интернетот и потребата од веб дизајн}

Компјутерските визионери кои го создале Интернетот, започнале со развивање на идејата уште во раните 60-ти години на минатиот век. На почетоците Интернетот бил употребуван за академски и владини цели. Својот подем го доживува како алатка за истражување и соработка, дозволувајќи им на научниците отсекаде да споделуваат информации. Во 1993 година се појавил првиот веб прегледник, за во годините кои следеле да биде колонизиран од луѓе со нова т.е. различна позадина. Секако, раниот Интернет нема многу допирни точки со денешниот Интернет. Тогашниот број на Интернет корисници бил мал, но истите имале експертско знаење и го употребувале исклучиво за работни цели. Денес постојат повеќе од 100 милиони веб локации и уште повеќе веб ентузијасти се онлајн.

Често некои луѓе ги користат термините Интернет и веб наизменично. Меѓутоа, технички, концептите се различни. Интернетот е мрежа од поврзани компјутери која го опфаќа целиот свет. Овие компјутери се поврзани заедно за да споделуваат информации, но има повеќе начини како може тоа да се оствари, вклучувајќи е-пошта, размена на инстант пораки, трансфер на датотеки преку протокол за трансфер на датотеки (File Transfer Protocol или FTP), преземање датотеки користејќи програми за поврзување корисник со корисник (peer-to-peer) итн. Вебот (или World Wide Web) е еден од многуте начини за размена на информации на Интернетот. Луѓето до овие информации стигнуваат со употреба на веб прегледници, за да посетат веб локации и да прегледаат веб страници отсекаде на светот.

Вебот ќе постои и без веб прегледниците, но луѓето нема да можат да го погледнат. Работата на веб прегледниците е многу едноставна, всушност се состои главно од две задачи ${ }^{1}$. Најпрво прегледникот побарува веб страници, ова се случува кога корисникот ја внесува веб адресата или притиснува на копче (врска) на некоја веб страница. Потоа прегледникот го испраќа барањето до веб сервер. Сервер е типично многу појак компјутер од еден персонален компјутер заради тоа што е потребно да се справи со повеќекратни прегледнички побарувања одеднаш. Серверот ги обработува овие

\footnotetext{
${ }^{1}$ M. MacDonald, Creating a Website: The Missing Manual, Third Edition, O’Reilly Media, Inc., Sebastopol, CA, USA, 2011 (p.8-9)
} 
барања и ја испраќа назад содржината на бараната веб страница. Кога ќе ја добие таа содржина прегледникот ја спроведува втората задача и ја рендерира веб страницата.

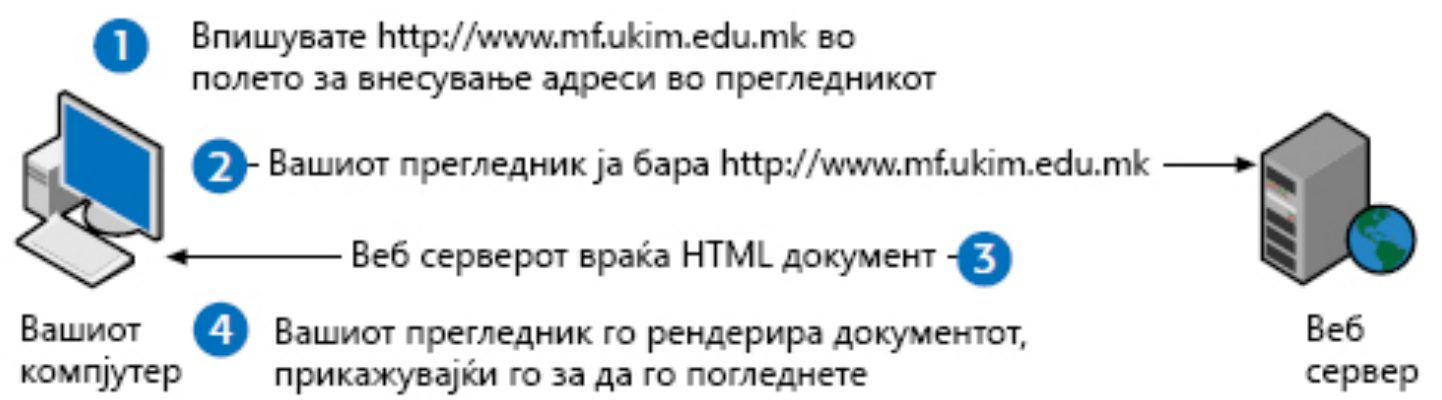

Слика 1 - Шематски приказ на работата на веб прегледниците

Од сето ова може јасно да се заклучи дека вебот не е зачуван на само еден компјутер и ниедна компанија не го поседува. Напротив, иднивидуалните делови (веб страниците) се распространети на милиони компјутери (веб сервери). Само една суптилна илузија ги прави овие локации да изгледаат како дел од една околина. Во реалноста, Интернетот е само сет од стандарди кои овозможуваат независни компјутери да комуницираат меѓу себе. Навигацијата низ оваа заплеткана мрежа на компјутери, за да стигне до бараната веб страница, прегледникот ја остварува со помош на униформен локатор на ресурси (Uniform Resource Locator или URL) - што во суштина е адресата на веб локацијата. 


\section{1. Постапки при креирање веб локација}

Со ширењето на Интернетот и неговата достапност во јавноста, се повеќе се зголемува потребата од веб дизајн. Генерално, дизајнирањето на веб локација е дефинирано ${ }^{2}$ како креирање и организирање веб страници кои заедно сочинуваат една локација на Интернет просторот. Меѓутоа, модерниот веб дизајн е дисциплина која опфаќа вештини од повеќе области. Следствено, за да создаде една обична веб страница, веб дизајнерот треба да поседува барем добри способности за дизајнирање (во смисла на правилна примена на дизајнерските принципи, кај интерфејсот и при уредувањето на содржината на веб страницата) и да ги разбира инструкциите, карактеристиките и атрибутите на HTML (Hypertext Markup Language) и CSS (Cascading Style Sheets) јазиците.

Секој дизајн подразбира решавање одреден проблем, дури и веб дизајнот. Независно од типот на проектот, процесот на дизајнирање скоро секогаш ги содржи во себе следните чекори³: запознавање со проектот, истражување, генерирање концепти, избирање решение и создавање.

Заради тоа што секој проект има свој сет на уникатни проблеми кои треба да се решат, витален дел при секој процес на дизајнирање е истражувањето. Тоа може да се спроведе со помош на повеќе алатки ${ }^{4}$, меѓу кои и:

- Интервју - алатка за спроведување истражување лице в лице при што се поставуваат одредени прашања кои се од интерес за проектот за да се дознае мислењето на лицето кое се интервјуира.

- Фокус групи - алатка за спроведување квалитативно истражување на одредена група луѓе за да се дознае нивниот став во однос на производот, услугата или концептот.

- SWOT (Strengths, Weaknesses, Opportunities and Threats) анализа - алатка за стратешко планирање која се користи за да се оценат предностите и слабостите вклучени во проектот.

\footnotetext{
${ }^{2}$ С. Сидоренко, Дизајн на веб страници, Умножени предавања, Скопје, 2010 (стр.6)

${ }^{3}$ M. Boulton, A Practical Guide to Designing for the Web, Mark Boulton Design Ltd., Penarth, UK, 2009. (p.49)

${ }^{4}$ M. Boulton, A Practical Guide to Designing for the Web, Mark Boulton Design Ltd., Penarth, UK, 2009. (p.46)
} 
- Анкета - алатка за истражување составена од серија прашања со цел собирање информации од одредена група испитаници.

- Пазарна сегментација - групирање на луѓе или организации врз основа на заеднички карактеристики (пр. локација, возраст, пол, социоекономски статус итн.) кои последователно предизвикуваат истите да имаат заеднички потреби од производот или услугата.

Целта при процесот на истражување пред сѐ е да се дојде до сознание за барањата и потребите на клиентот (нарачателот) и на корисниците. Најчесто, најпрвин се интервјуира нарачателот за да се дознае идејата на проектот, целите кои се очекува да ги исполни и групата корисници за која ќе биде наменет. Следно е анкетирањето на корисниците за подобро да се дознаат нивните барања и потреби и како истите се вклопуваат во замислите на нарачателот. На крај се сумираат сите добиени информации и се создава конкретен пристап за решавање на дизајнерскиот проблем.

Откако ќе се изврши истражувањето, следува процесот на планирање и организирање на веб локацијата. Овој процес е пожелно да се изврши на самиот почеток на проектот заради понатамошна заштеда на време. Планирањето подразбира и креирање/собирање на сите потребни содржини (текстови, слики, анимации, видео и звучни записи) за веб локацијата. Притоа, треба да се има предвид содржините да бидат соодветни за корисниците (во однос на нивната експертиза), добро да се вклопуваат во страниците каде треба да бидат сместени и да функционираат правилно на сите уреди, сѐ со цел правилно насочување кон исполнување на потребите и однесувањето на корисниците. Оваа фаза е многу значајна во процесот на креирање на една веб локација. Потоа се организираат информациите и одредува структурата на веб локацијата, за да може да се премине на креирање на веб локацијата.

Следна фаза е генерирање концепти за изгледот на одредени типски страници од веб локацијата. Во оваа фаза се прават повеќе итерации на концептите сѐ додека не се дојде до одреден број прифатливи решенија. Од нив понатаму се одбира еден концепт кој понатаму се усовршува (доколку е потребно) за да се усвои конечниот изглед на сите веб страници на веб локацијата. Откако ќе се комплетира дизајнот, се 
почнува со градење на веб локацијата и се кодираат веб страниците - се додава содржината и интерактивните елементи. Понатаму, страниците се поврзуваат со хиперврски и се проверува нивната функција. Освен тоа се тестира дали веб локацијата се прикажува и функционира правилно на сите предвидени уреди. На крај, за да може изработената веб локација да биде достапна за јавноста, истата треба да биде публикувана т.е. треба да биде поставена на веб сервер.

По сето ова, пожелна е периодична проверка за да се осигури активноста и правилното функционирање на веб локацијата. Најдобрите веб локации постојано се подобруваат, кога не се води грижа за веб локацијата таа полека замира - посетеноста се намалува и страда имиџот на лицето или организацијата која ја поседува. 


\section{2. Анатомија на веб страниците}

Кога ќe се разгледа подобро, веб страницата не е ништо повеќе од текстуална датотека која содржи HTML инструкции и атрибути кои веб прегледникот треба да ги прикаже како информација на екранот. Практично, не е потребна специјализирана програма за создавање на веб страница, туку доволно е само општо познавање на HTML јазикот и програма за уредување текст.

Meѓyтоа, денес постојат повеќе апликативни софтвери кои овозможуваат едноставно интерактивно креирање на веб страници, така што не е потребно ни големо познавање на HTML јазикот, бидејќи самите програми автоматски го генерираат HTML кодот. Предноста од примената на ваквите програми е тоа што креаторите веднаш гледаат како ќе изгледа веб страницата кога ќе биде повикана преку веб прегледникот. Но, некогаш може да се случи овие програми да генерираат повеќе код отколку што е неопходно или пак да генерираат погрешен код кој нема да интерпретира одредена инструкција во прегледникот онака како што предвидувал креаторот.

Секоја веб страница потребно е да ги има следните компоненти5: контејнер, блок за идентификација со лого, блок за навигација, блок со содржина, долен блок и празен простор. Наведените компоненти имаат некои однапред прифатени позиции од корисниците кои се очекува да се почитуваат при уредувањето на целата содржина.

\footnotetext{
${ }^{5}$ J. Beaird, The Principles of Beautiful Web Design, SitePoint Pty. Ltd., Australia, 2007. (p.7-8)
} 

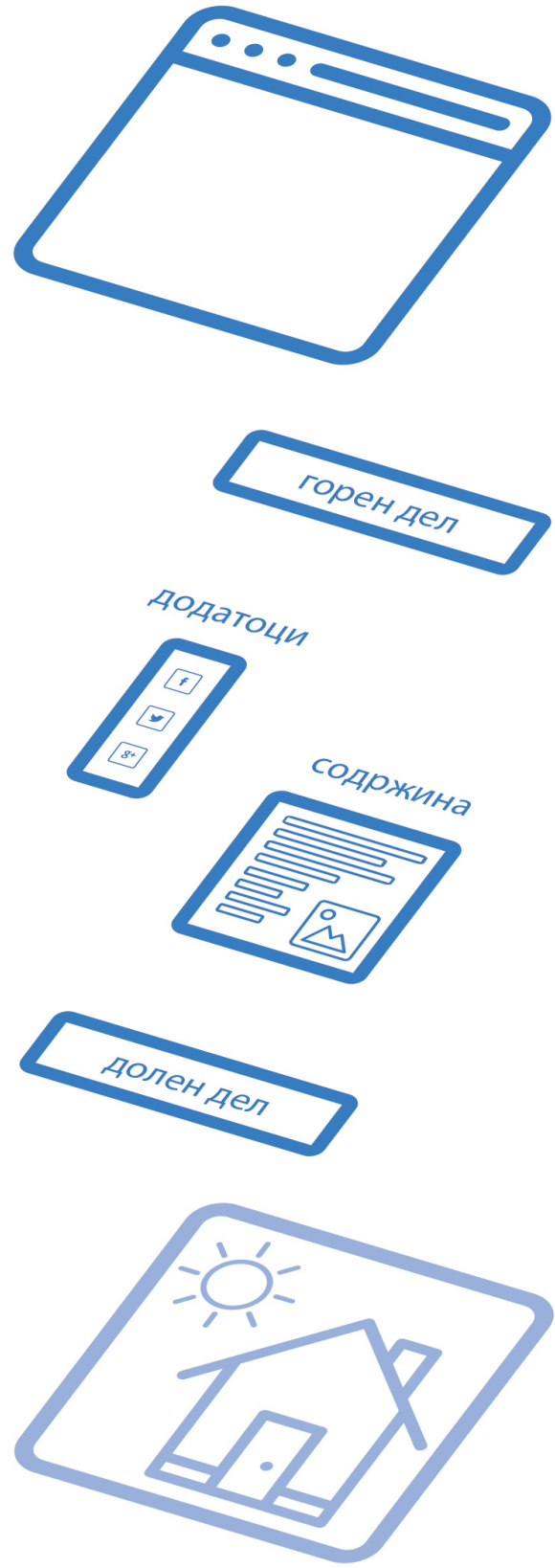

Слика 2 - Шематски приказ на вообичаените компоненти на една веб страница 
Есенцијална компонента на секоја веб страница е некаков вид на контејнер, во кој би била сместена содржината. Тој може да биде во форма на body ознака, div ознака, па дури и застарениот table елемент. Контејнерот може да има фиксна широчина или променлива широчина, во зависност од потребата. Во спротивно, доколку не постои контејнер, содржината на страницата би била расфрлана насекаде без некаков ред.

Блокот за идентификација со лого е најзначајната компонента на веб страницата за секој бренд. Се очекува да биде поставен во најгорниот дел на веб страницата, со тоа што најчесто логото во него е поставено од левата страна или во центарот. Тоа е првото нешто што се забележува на веб страницата и треба соодветно да го претставува идентитетот на компанијата, во смисла на искористените бои и фонт.

Блокот за навигација има претрпено доста промени со текот на годините. Највпечатлива промена е неговото позиционирање. На почетоците се поставувал од левата страна и се простирал вертикално, за со тек на време да се премине кон поставување хоризонтално веднаш под блокот за идентификација, а денес му е додадена и дополнителна функционалност на активирање т.е. комплетно прикажување од одредена скриена позиција со притискање на копче кое најчесто е поставено во линија со блокот за идентификација на лева или десна страна (зависно од дизајнот). Доброто движење низ веб локацијата директно зависи од успешното позиционирање и функционирање на навигацијата во сите прегледници. Затоа кај навигацијата не треба да се оставаат случајности.

Во блокот со содржина, како што кажува и самиот назив се сместува целата содржина која треба да се прикаже на дадената страница. Меѓутоа, кога се зборува за блокот со содржина, нешто на коешто најмногу треба да се внимава е преклопот. Преклопот го опфаќа делот кој е видлив за корисникот кога првично се прикажува страницата. Изразот е преземен од концептот на превиткан весник, каде што сите значајни наслови и важни вести се содржани во горната половина, сѐ со цел полесно да бидат забележани и кога не е отворен весникот. Кај веб страниците, во овој дел влегуваат сите претходно наведени компоненти, а неговата големина вообичаено е околу 600px (иако кај екрани со поголеми димензии соодветно се зголемува). Затоа треба да се внимава колку простор е преостанат за блокот со содржина и каква содржина ќе се смести токму во овој видлив дел. Доколку посетителите на страницата 
не ги најдат бараните информации во овој простор извесно е дека ќе ја напуштат веб локацијата целосно.

На крај на веб страницата се простира долниот блок, чија локација се подразбира од називот. Во овој блок се очекува да бидат дадени брзи врски до одредени страници кои се од значење за посетителите, а кои се дел од веб локацијата, како и кратки контакт информации. Целта на ова е да се намали потребата од движењето по страницата за да се стигне повторно до блокот за навигација, односно доколку е потребно да се стапи во контакт со компанијата едноставно и брзо без да има потреба да се пристапува до страницата наменета за контакт.

Кога ќе се спомене празен простор како компонента од една веб страница, често доаѓa до зачудување, но доделувањето доволно празен простор е исто така важно за содржината. Доколку не се остави доволно празен простор на една веб страница, нема да дојде до израз поставената содржина и ќе се добие впечаток на загушеност на содржините. Целосното исполнување на веб страницата со содржина не е толку од корист за компанијата, колку што е поставувањето одредена количина која е потребна посетителот да ја прочита за да одлучи да стапи во контакт со компанијата (доколку е тоа потребно). 


\section{3. Прилагодлив веб дизајн}

Интернетот се менува постојано и многу побрзо отколку што може да се замисли. На почетокот тој не се користел за рекреативни активности и за негова употреба се користеле единствено компјутери. Денес ситуацијата е многу поразлична, пристап до Интернет се остварува од многу различни уреди и тоа: таблет компјутери, мобилни телефони, телевизори, домашни кина, играчки конзоли итн. и тоа за најразлични намени. Следствено, присуството на Интернет просторот е од големо значење, но сега правилното прикажување на веб локацијата на различните типови уреди е од огромно значење.

Имено, едно истражување ${ }^{6}$ спроведено од компанијата Nielsen покажало дека 77\% од сите пребарувања од мобилни уреди се случиле од домот или работното место на испитаникот. Што значи дека дури и во услови кога десктоп или лаптоп компјутери им биле достапни на испитаниците, најголемиот дел од нив сметале дека е попригодно нивното пребарување да го извршат од некој мобилен уред.

Во минатото, едно решение кое многу компании го применувале било дизајнирањето различни верзии на истата веб локација за различни типови корисници. Меѓутоа, тоа довело до неколку клучни проблеми:

- Било потребно да се плати за повеќе веб дизајни

- Било потребно да се направат одделни оптимизации за пребарувачи (Search Engine Optimization или SEO)

- Било потребно да се водат одделни Интернет маркетинг кампањи

На крајот се завршувало со трошење на многу повеќе време и средства отколку што навистина било потребно. Заради ова, гледано од бизнис перспектива, не е многу разумно ниту пак исплатливо да се дизајнираат повеќе верзии на истата веб локација (освен доколку не е потребен комплетно различен изглед на секоја од верзиите).

\footnotetext{
${ }^{6} \mathrm{http} / / /$ searchengineland.com/study-55-percent-of-mobile-search-driven-conversions-happen-in-one-houror-less-151432

${ }^{7}$ T. Southers, White Paper: Responsive Website Design, i5ww LLC, Dallas, TX, USA, 2013.
} 
Модерното решение на гореспоменатиот проблем е прилагодливиот веб дизајн. Можеби звучи комплексно, но всушност е многу едноставен по природа. Ова решение овозможува веб локацијата да биде дизајнирана онака како би се прикажувала соодветно на сите позначајни типови на уреди или пак на специфични уреди кои се од интерес и истата би била релативно едноставна за употреба на секој од нив. Наместо повеќе веб дизајни, повеќе Интернет маркетинг кампањи и залудно потрошено време и финансии, има еден дизајн кој треба да се следи т.е. управува и одржува.

Во ваков случај, доколку некоја од големите компании кои произведуваат ИТ уреди се одлучи да произведе некој нов иновативен производ или некои постоечки напредни производи станат подостапни за широките народни маси, веб локацијата ќе биде целосно подготвена да ги опслужи на правилен начин. Конечно, за да се отстранат сите сомнежи дека ова е вистинското решение, треба да се напомене дека е препорачано 8 од Google и згора на тоа како пребарувач им дава подобри рангирања на веб локациите кои користат прилагодлив веб дизајн отколку на оние кои не го користат ова решение.

Во суштина прилагодливиот веб дизајн се заснова ${ }^{9}$ на една функција испитување на можностите на уредот (Media Queries). Конкретно, со примена на „@media“ правилото се дефинира на одредена ширина на „screen“ типот на медиум да се менува главниот CSS код (т.е. стил) со посакуваниот.

Генерално, има два пристапи ${ }^{10}$ на кодирање во ваквиот дизајн. Според првиот, се започнува со дефинирање на стиловите за персоналните компјутери, па се дефинираат односно постапно се деградираат стиловите надолу сѐ до верзијата за мобилните уреди.

\footnotetext{
${ }^{8} \mathrm{http}: / /$ www.business2community.com/seo/google-recommends-responsive-web-design-01159920

${ }^{9} \mathrm{http}: / /$ webdesign.about.com/od/layout/a/responsive-design.htm

${ }^{10} \mathrm{https}: / /$ codemyviews.com/blog/mobilefirst
} 


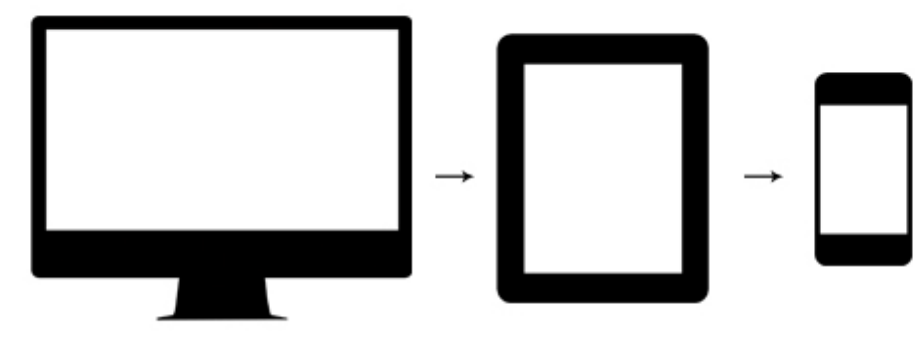

Слика 3 - Шематски приказ на „Desktop Down“ пристапот

Додека во вториот пристап се започнува со дефинирање на стиловите за мобилната верзија, па се надградуваат сѐ до верзијата за персонални компјутери.

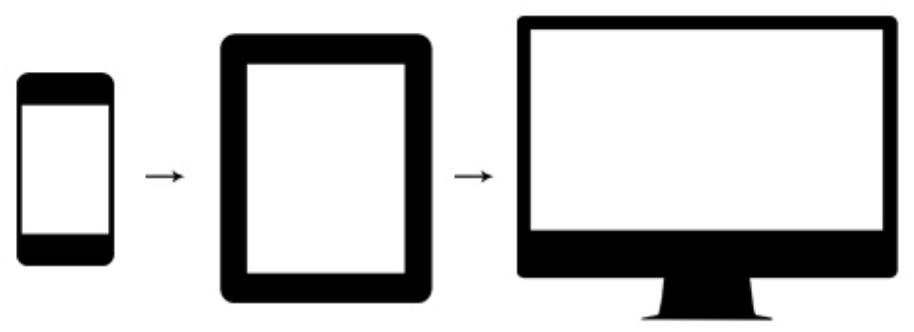

Слика 4 - Шематски приказ на „Mobile First“ пристапот

Најпочитуван пристап од заедницата на веб развивачи е токму вториот пристап, кој е попознат како Mobile First, бидејќи само неопходно потребните елементи се вчитуваат при пристапување од мобилните уреди. Имено, за да се заштеди на количината на преземени податоци (пр. да нема потреба од Wi-Fi пристап) и оптоварувањето на хардверските ресурси, често не се активираат одредени елементи (пр. слики, видеа итн.) кај мобилните верзии на страниците. Како резултат на сето ова 
се зголемува брзината на вчитување на самата страница и добивање повратна информација, што директно влијае и на подобрување на корисничкото искуство. Истото не може да се постигне доколку се кодира најпрво за персоналните компјутери т.е. co Desktop Down пристапот. Причината е многу едноставна. Иако несаканите елементи се сокриени истите не се и деактивирани, па при вчитувањето на страницата тие се процесираат исто како да се вчитува целосната верзија (при што се остварува и поголем Интернет сообраќај), за дури потоа да се оневозможи нивната видливост. Друг аспект на кој треба да се оддаде внимание при имплементирањето на веб локација со прилагодлив веб дизајн е поддршката од постарите веб прегледници (пр. Internet Explorer 8), кои во суштина не го препознаваат „@media“ правилото. Тука исто така доаѓ до израз она што е прво во кодот т.е. применетиот пристап на кодирање во прилагодливиот веб дизајн - Mobile First или Desktop Down, бидејќи сѐ што е вон опфатот на „@media“ правилото ќе биде процесирано. Меѓутоа, бројот на Интернет корисници кои прегледуваат веб локации со постари верзии на прегледници од ден на ден е се помал, што значи дека Mobile First станува се пооправдан за примена. Од друга страна, постои и придобивка од Mobile First пристапот во однос на печатењето на веб страниците. Токму заради она што е прво во кодот, страниците се печатат без слики што во повеќето случаи и не е на одмет, бидејќи поважна е содржината отколку сликите (и се остварува заштеда на тонер).

Најзначајни придобивки ${ }^{11}$ од употребата на прилагодлив веб дизајн се:

- Поедноставена одржливост - поседувањето различни верзии на истата веб локација за различни типови корисници подразбира и одделно одржување на истите, со новиот пристап обновувањето на содржината е полесно и координирањето на Интернет маркетингот е поедноставно.

- Подобрено корисничко искуство - дизајнирањето една веб локација која опслужува повеќе групи на корисници нема да доведе до нивно разочарување, што е случај кај веб локации кои се дизајнираат исклучиво за десктоп или лаптоп компјутери.

- Зголемена посетеност - ова е директно поврзано со претходното тврдење, колку позадоволни корисници толку поголема посетеност, но исто така и

\footnotetext{
${ }^{11}$ T. Southers, White Paper: Responsive Website Design, i5ww LLC, Dallas, TX, USA, 2013.
} 
колку повисоко е рангирана веб локацијата при пребарување, толку покредибилна се перципира од страна на корисниците.

- Олеснето следење на аналитиките - однесувањето на корисниците е полесно да се следи на една отколку на повеќе верзии на одредена веб локација.

- Поедноставен Интернет маркетинг - многу полесно е да се привлечат врски до веб локација со еден назив отколку до веб локација со повеќе (за секоја верзија посебен).

- Заштедување финансии - колку помалку верзии на една веб локација е потребно да се одржуваат, толку повеќе финансии се заштедуваат.

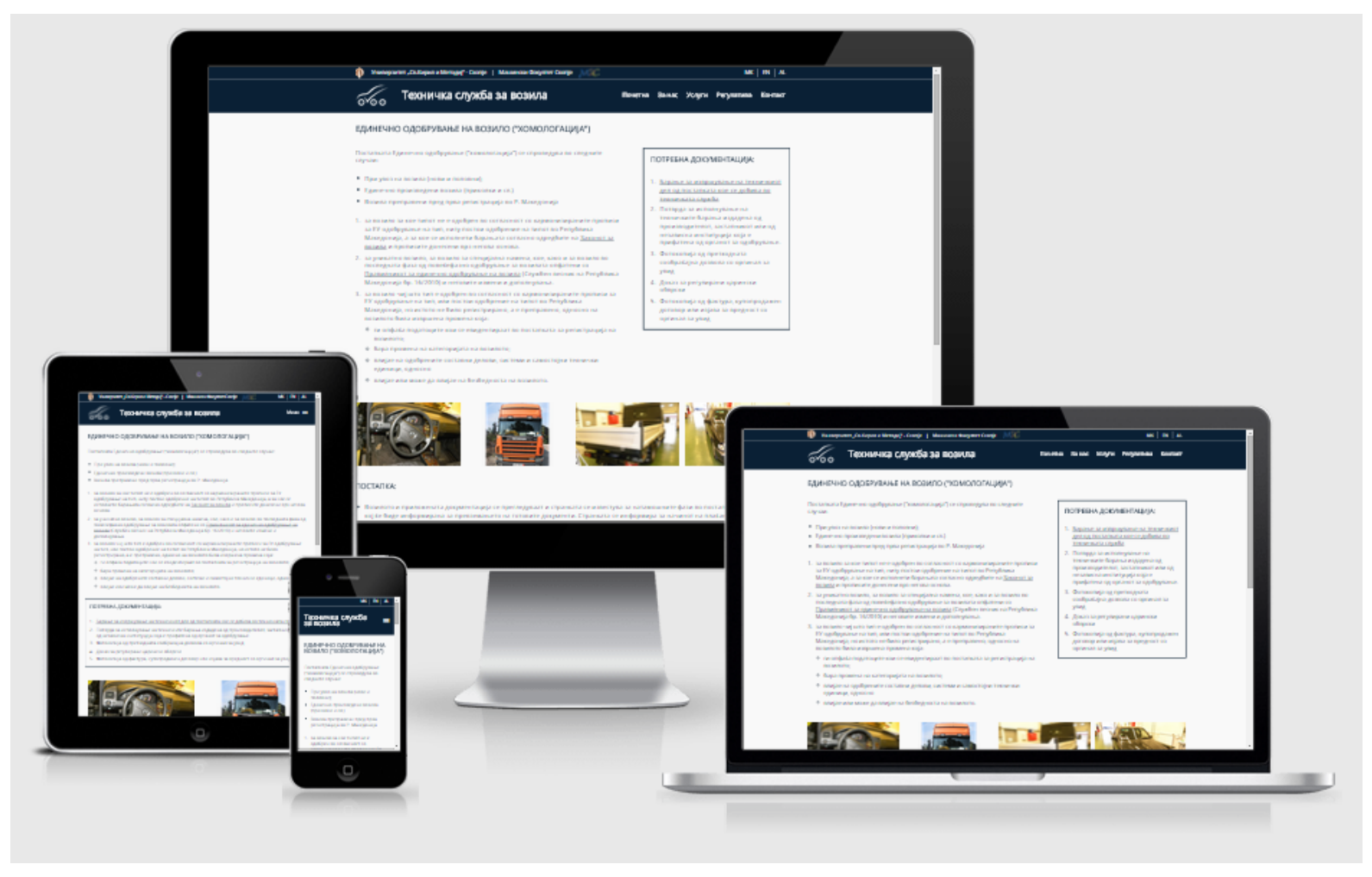

Слика 5 - Пример за веб страница со прилагодлив веб дизајн 


\section{3. Перцептивни фактори во веб дизајнот}

Сите правила во дизајнот се базирани на човечката психологија - како луѓето перципираат, учат, размислуваат, запомнуваат и претвораат интеракции во акции. Многу автори на насоки за дизајнирање имале барем некаква позадина во психологија која може да се примени во дизајнот на компјутерските системи.

Следењето на насоките за дизајнирање кориснички интерфејси не е баш едноставен процес, бидејќи правилата во дизајнот често опишуваат цели наместо акции. Исто така, тие се генерализирани со намера, за да можат да бидат широко применети. Ова истовремено значи дека нивното точно значење и нивната примена во специфична ситуација во дизајнот е отворена за интерпретација. За да се задоволат сите дизајнерски цели за еден компјутерски производ или услуга вообичаено потребно е да се направат одредени исклучоци и да се создаде одреден баланс.

Човечката перцепција за околината во голем дел се сведува на следното: „Го перципираме она што очекуваме да го перципираме“. Очекувањата, односно перцепциите, се основаат на три фактори ${ }^{12}$ :

- Минатото: нашето искуство

- Сегашноста: моменталниот контекст

- Иднината: нашите цели
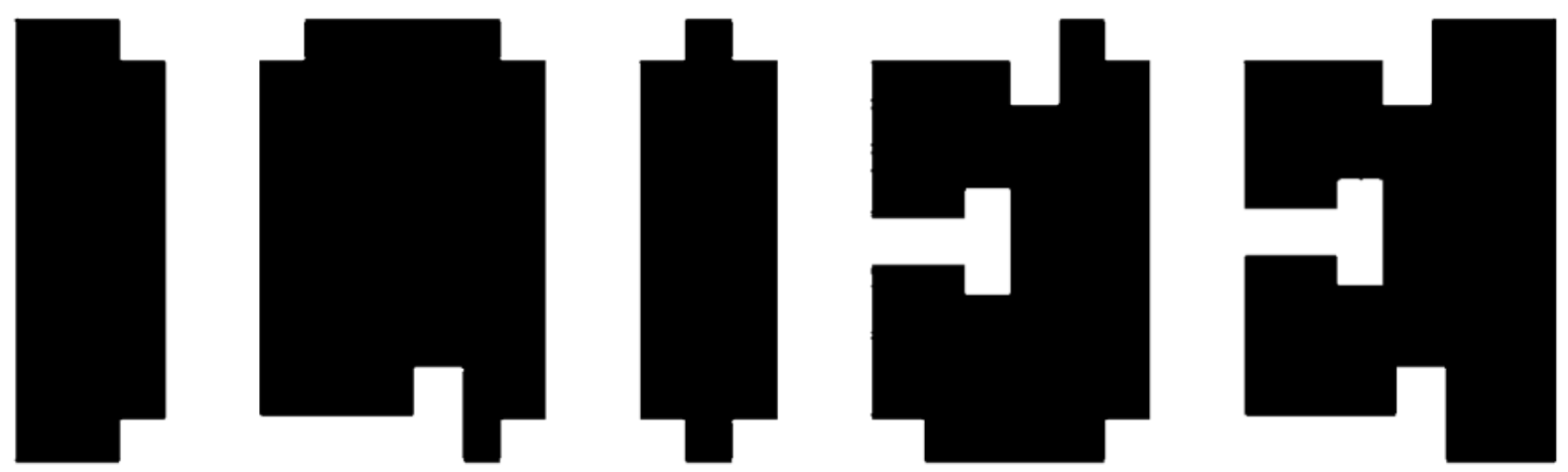

Слика 6 - Илустрација за докажување на влијанието на искуството врз перцепцијата

\footnotetext{
12 J. Johnson, Designing with the mind in mind, Morgan Kaufmann Publishers, Burlington, MA, USA, 2010. (p.1)
} 
Кога перцептивниот систем бил навикнат често да гледа облици на објекти, набљудувачот на сликата ќе гледа облици на објекти, додека белиот простор едвај ќе биде забележан. Во друг случај, кога перцептивниот систем бил навикнат да гледа текст, набљудувачот на сликата ќе гледа букви, а црниот простор едвај ќе биде забележан.

Кога станува збор за компјутерски корисници, тие често притискаат на копчиња или врски без да погледнат со внимание на нив. Нивната перцепција на екранот е основана повеќе на нивното минато искуство, што ги наведува да очекуваат нешто што во суштина не е така. Ова на некој начин ги ограничува дизајнерите на кориснички интерфејси кои очекуваат корисниците да ги гледаат со внимание екраните. На следната слика е даден пример за претходно споменатото.
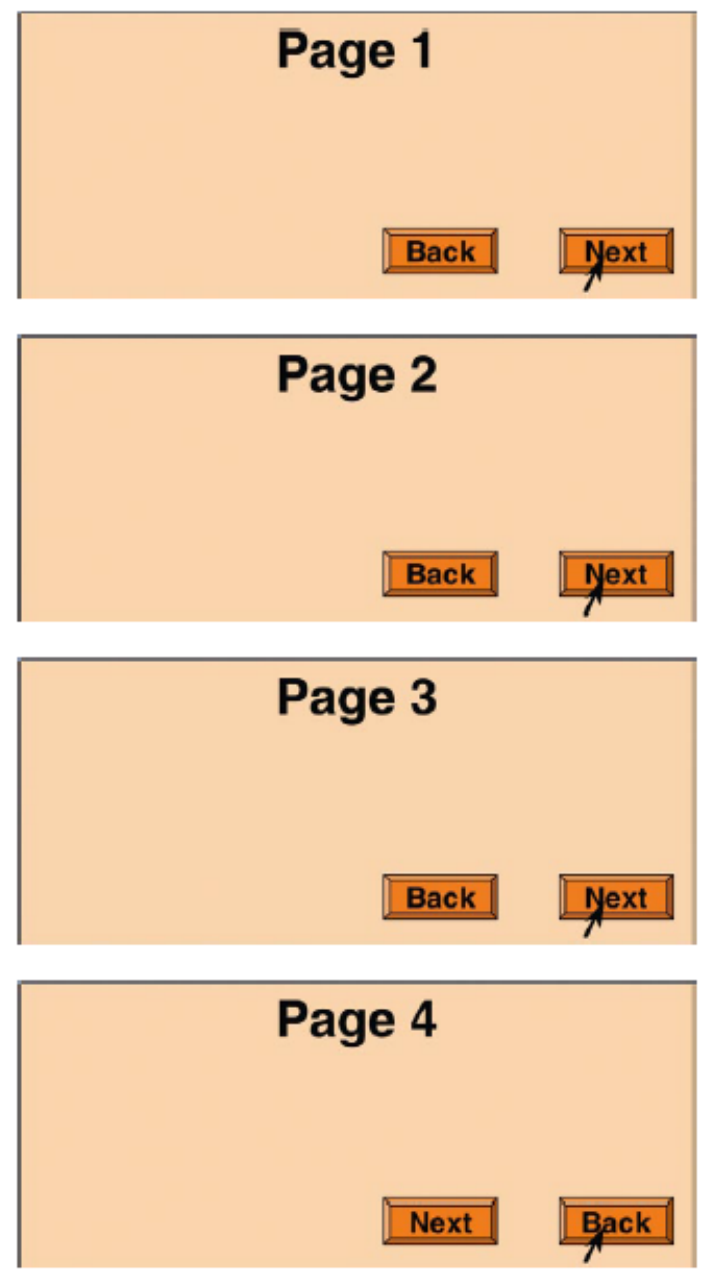

Слика 7 - Илустрација за докажување на влијанието на минатото искуството врз перцепцијата 
Со навикнувањето на позицијата на копчињата, корисниците често на последниот екран не забележуваат дека нивната позиција е променета. Нашата перцепција исто така е под влијание и на нашите цели и идни планови. Конкретно, нашите цели ги филтрираат нашите перцепции - потсвесно, нешта кои не се поврзани со нашите цели имаат тенденција да не бидат забележани. Токму заради овие причини, се создадени неколку насоки ${ }^{13}$ во дизајнот на кориснички интерфејси:

- Избегнувајте двосмисленост - избегнувајте двосмислени екрани со информации и тестирајте го дизајнот за да се осигурите дека сите корисници го интерпретираат екранот на ист начин. Онаму каде не може да се избегне двосмисленост, или потпрете се на веќе воспоставени стандарди или подгответе ги посетителите да ја разрешат двосмисленоста на одреден предвиден начин.

- Бидете конзистентни - поставете информации и контроли на конзистентни локации. Контролите и екраните со податоци кои ја служат истата функција на различни страници треба да бидат поставени на истата позиција на секоја страница на која се појавуваат. Треба да ја имаат истата боја, истиот фонт на текст, исто сенчење итн. Оваа конзистентност им овозможува на корисниците да ги забележат и препознаат брзо.

- Разберете ги целите - корисниците доаѓаат на веб локацијата со одредени цели кои сакаат да ги постигнат. Дизајнерите треба да ги разберат тие цели, да сфатат дека целите на корисниците може да варираат и дека нивните цели цврсто влијаат на тоа што тие перципираат и треба да осигурат дека во секоја точка во интеракцијата информацијата која им е потребна на посетителите е достапна, истакната и јасно да покажува кон одредена корисничка цел за корисниците да ја забележат и да ја употребат информацијата.

Исто како што системот за вид има предности и недостатоци, така и човечката меморија има предности и недостатоци. Следствено, може да се дизајнираат интерактивни системи кои ја поддржуваат и зголемуваат меморијата, наместо да ја

\footnotetext{
${ }_{13}$ J. Johnson, Designing with the mind in mind, Morgan Kaufmann Publishers, Burlington, MA, USA, 2010. (p.89)
} 
оптоваруваат и збунуваат. Психолозите одамна извршиле поделба ${ }^{14}$ на човековата меморија на краткотрајна и долготрајна меморија. Краткотрајната меморија опфаќа ситуации во кои информацијата е зачувана за многу краток временски интервал, кој може да опфати период од дел од секунда до неколку секунди или во исклучителни случаи најмногу една минута. Долготрајната меморија од друга страна опфаќа ситуации во кои информацијата е зачувана подолги временски периоди и истата може да се запамети од неколку минути, часови, денови, години, па дури и доживотно во некои случаи.

Капацитетот и непостојаноста на краткотрајната меморија имаат многу импликации ${ }^{15}$ врз дизајнот на интерактивни компјутерски системи. Основната импликација е тоа што корисничките интерфејси треба да се дизајнирани онака како би им помогнале на корисниците да ги запаметат есенцијалните информации од еден момент до друг. Не треба да се обврзуваат корисниците да ја запаметуваат состојбата на системот или што направиле, бидејќи нивното внимание е фокусирано на нивната примарна цел и процесот кон нејзино постигнување. Типичен пример за ова е процесот на пребарување. Кога луѓето ја користат функцијата за пребарување на компјутерите за да пронајдат одредена информација, тие ги внесуваат термините за пребарување, го започнуваат пребарувањето и потоа ги прегледуваат резултатите. Во моментот кога се прикажуваат резултатите вниманието на корисникот се насочува од внесените термини за пребарување кон резултатите. Меѓутоа, заради ограниченоста на краткотрајната меморија најчесто луѓето забораваат кои термини за пребарување ги внеле претходно и не можат да извршат добра оценка на добиените резултати. Заради ова при дизајнирањето на модулот за пребарување потребно е да се овозможи прикажување на внесените термини во полето за внесување текст и откако ќе се изврши пребарувањето.

Клучното нешто кое карактеристиките на долготрајната меморија го имплицираат ${ }^{16}$ е дека на луѓето им се потребни алатки за истата да ја зголемат. Во најмала рака

\footnotetext{
${ }^{14} \mathrm{~J}$. Johnson, Designing with the mind in mind, Morgan Kaufmann Publishers, Burlington, MA, USA, 2010. (p.79)

${ }^{15}$ J. Johnson, Designing with the mind in mind, Morgan Kaufmann Publishers, Burlington, MA, USA, 2010. (p.86)

${ }^{16}$ J. Johnson, Designing with the mind in mind, Morgan Kaufmann Publishers, Burlington, MA, USA, 2010. (p.92)
} 
дизајнерите треба да избегнуваат да развиваат системи кои ја оптоваруваат долготрајната меморија. Докажувањето на автентичноста е една функционална област во која многу софтверски системи поставуваат оптоварувачки барања на корисничката долготрајна меморија. Еден пример за ова е бројот за лична идентификација (PIN) кој се употребува во многу веб апликации, кој би требало да е лесен за помнење од страна на корисникот, но некогаш ограничувањата кои ги поставуваат развивачите го прават процесот на долготрајно помнење потежок. Често пати се сугерира овој број корисниците да го запишат на хартија и да го чуваат. Настрана што тоа само по себе претставува ризик за безбедноста, туку и создава дополнителна обврска за паметење кај корисникот во однос на местото каде се чува запишаното.

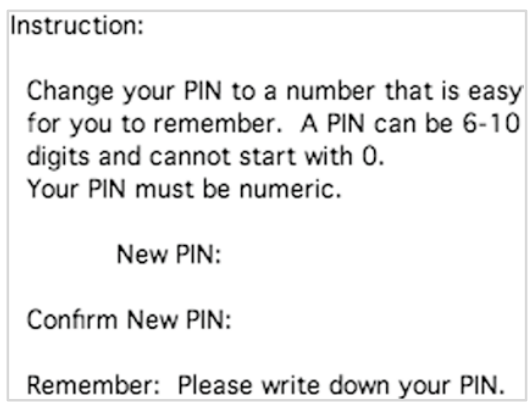

Слика 8 - Пример за формулар за лична идентификација

Луѓето знаат дека нивното внимание е ограничено и се однесуваат соодветно. Кога тие се во некаква интеракција со околината, вклучувајќи ги и компјутерските системи, некои аспекти од нивното однесување следат одредени предвидливи патеки ${ }^{17}$. Додека се обидуваат да спроведат одредена цел, луѓето превземаат познати чекори секогаш кога е тоа можно наместо да истражат нови, особено кога постои одредено временско ограничување за извршување на целта. Ова се случува бидејќи следењето добро познати патеки може да биде извршено доста автоматски и не ја оптоварува краткотрајната меморија и вниманието на корисникот. Последица на сето ова е тоа што откако ќе научат еден начин како да извршат одредена задача користејќ некој софтвер луѓето често продолжуваат да ја извршуваат на тој начин и никогаш не

\footnotetext{
17 J. Johnson, Designing with the mind in mind, Morgan Kaufmann Publishers, Burlington, MA, USA, 2010. (p.97)
} 
откриваат некој нов поефикасен начин. Дури и да пронајдат или да им е укажано дека постои подобар начин, повторно може да се придржуваат кон стариот начин бидејќи им е познат, комфорен и највеќе од сѐ не создава потреба од многу размислување. Избегнувањето на зголемена потреба за размислување при употребата на компјутери е важна, бидејќи луѓето се подготвени да прават повеќе за да размислуваат помалку. Затоа интерактивните системи треба да бидат дизајнирани така да со промисленото поставување на содржините/информациите би ги навеле корисниците кон нивните цели. За да се постигне ова, дизајнерите треба да ги разберат целите за кои е поголема веројатноста дека корисниците ќе ги имаат при секоја задача, да понудат и јасно да ги истакнат можностите за нивно постигнување при секоја ситуација за одлука. 


\section{1. Гешталт принципи}

На почетокот на дваесеттиот век, група германски психолози се обиделе да објаснат како човечката визуелна перцепција функционира. Тие набљудувале и забележале многу важни визуелни феномени. Еден од нивните основни пронајдоци бил дека човечкиот вид е сеопфатен - Нашиот систем за вид автоматски наметнува структура при визуелен внос и е предодреден да перципира облици, фигури и објекти во целост, наместо неповрзани рабови, линии и области. Германскиот збор за „облик“ или „фигура“ е „гешталт“ (гер. gestalt), па овие теории станале познати како Гешталт принципи ${ }^{18}$ на визуелна перцепција. Денес, тие наоѓаат доста корисна примена и како насоки за графички дизајн и дизајн на кориснички интерфејси. Најзначајни Гешталт принципи се: блискост, сличност, континуитет, затвореност, симетрија, облик/позадина и (заедничка судбина) поврзаност.

Гешталт принципот на блискост е изразен преку релативното растојание помеѓу објектите на еден екран кое влијае на нашата перцепција во однос на тоа дали и како објектите ќе бидат организирани во подгрупи. Објектите кои се блиску еден до друг (релативно во однос на други објекти) наликуваат како да се групирани, додека оние кои се подалеку не наликуваат така. Овој принцип има очигледна релевантност кога станува збор за распоредот на контроли/копчиња или формулари при дизајнот на софтвер, веб дизајнот, па дури и дизајнот на електрични производи. Дизајнерите често одвојуваат групи на копчиња и податоци кои се прикажуваат на екранот со нивно затворање во кутии или со поставување на линија за раздвојување помеѓу групите.

\footnotetext{
18 J. Johnson, Designing with the mind in mind, Morgan Kaufmann Publishers, Burlington, MA, USA, 2010. (p.11-24)
} 


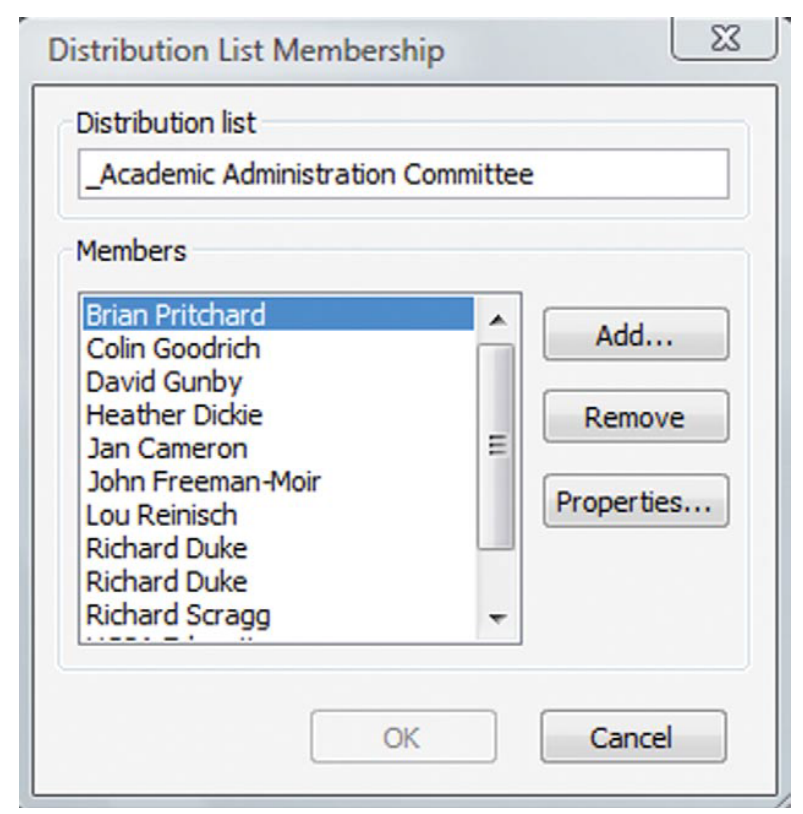

Слика 9 - Пример за кориснички интерфејс каде е применет Гешталт принципот на блискост

Meѓyтоа, според принципот на блискост, елементите на екранот можат визуелно да се групираат едноставно со нивно поставување поблиску еден до друг во однос на други елементи, без да се користат разни графички разграничувања. Повеќе експерти од областа на графичкиот дизајн го препорачуваат овој пристап за да се намали визуелното натрупување и големината на кодот во корисничкиот интерфејс.

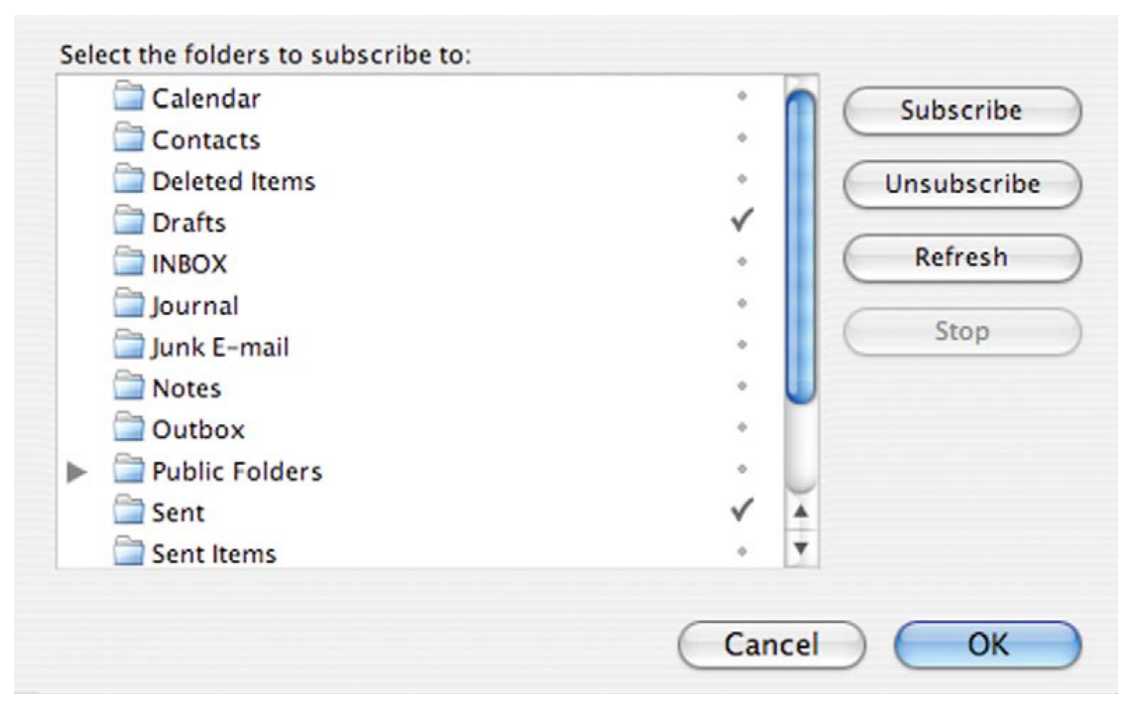

Слика 10 - Пример за кориснички интерфејс каде е применет Гешталт принципот на блискост 
Спротивно на ова, доколку копчињата се лошо распоредени (пр. доколку поврзани контроли се многу оддалечени едни од други) корисниците ќе имаат проблеми при нивното перципирање како поврзани, последователно правејќи го софтверот тежок за учење и помнење.

Во Гешталт принципот на сличност е изразен уште еден фактор кој влијае на човечката перцепција во однос на групирањето на елементите на екранот. Имено, објектите кои изгледаат слично наликуваат како да се групирани.

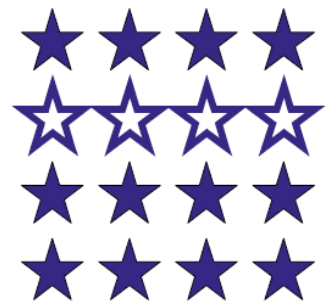

Слика 11 - Илустрација на Гешталт принципот на сличност

Во дизајнот на дијалог прозорецот за поставките на страниците кај апликации во Мас оперативниот систем се искористени принципите на сличност и блискост за да се спроведе групирање. Трите слични и блиско поставени икони за ориентација јасно се наменети да изгледаат групирани. Од друга страна, трите менија не се поставени блиску, но изгледаат доволно слично така што наликуваат како да се поврзани, а тоа веројатно не била целта на дизајнерот.

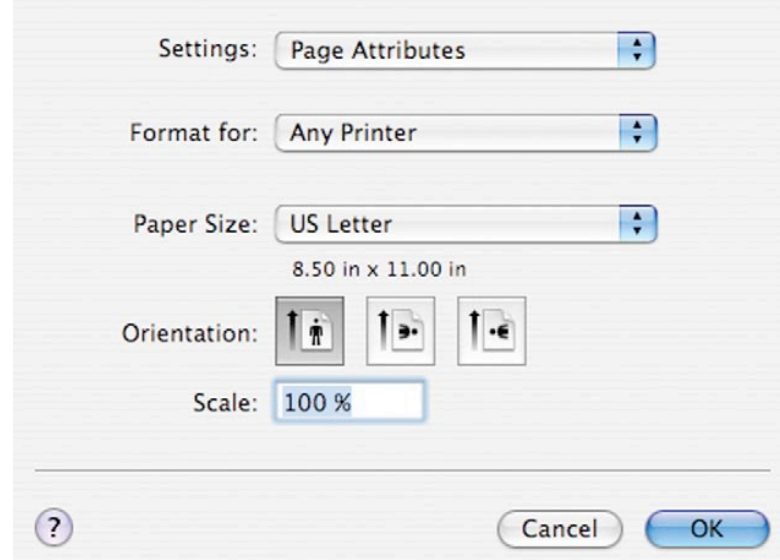

Слика 12 - Пример за кориснички интерфејс каде се применети Гешталт принципите на блискост и сличност 
Слично на ова, полињата за внесување текст во формуларот на една веб локација се организирани во неколку групи. Но, групирањето е извршено со визуелно разграничување помеѓу полињата со помош на менија. Единствен недостаток во овој дизајн е поставеноста на ознаките за полињата. Тие се премногу оддалечени од нив за да изгледаат како да се поврзани со соодветното поле.

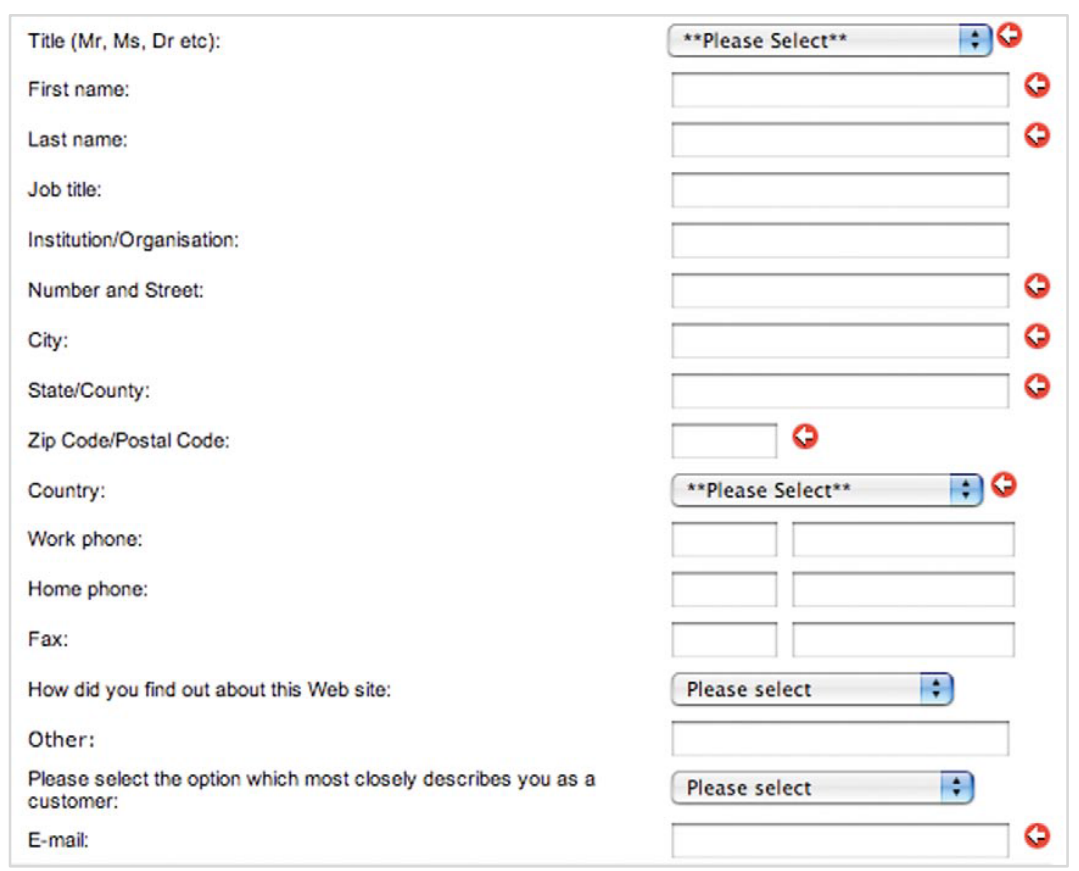

Слика 13 - Пример за формулар каде е применет Гешталт принципот на сличност

Дополнително на двата претходно споменати Гешталт принципи кои се однесуваат на нашата тенденција да ги организираме објектите во групи, неколку Гешталт принципи ја објаснуваат тенденцијата на нашиот систем за вид да ја разрешува двосмисленоста или да ги пополнува податоците кои недостасуваат на таков начин како би се перципирале цели објекти. Првиот таков принцип е принципот на континуитет, кој искажува дека нашата визуелна перцепција е ограничена да перципира континуирани форми отколку неповрзани сегменти. Добро познат пример за примената на континуитетот во графичкиот дизајн е логото на компанијата IBM. Тоа се состои од неповрзани сини парчиња, а воопшто не изгледа двосмислено туку едноставно се гледа како три задебели букви. 


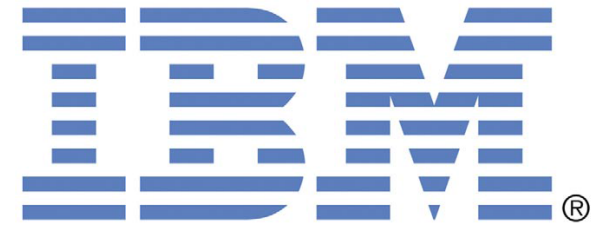

Слика 14 - Пример за лого каде е применет Гешталт принципот на континуитет

Лизгачките контроли се пример на принципот на континуитет во дизајнот на кориснички интерфејси. Имено, лизгачот го перципираме како еден опсег во кој има покажувач, а не како два посебни опсега одвоени токму од покажувачот. Дури и при прикажување на различни бои на лизгачот на секоја страна од покажувачот не создава целосна поделба во нашата перцепција за лизгачот како еден континуиран елемент.

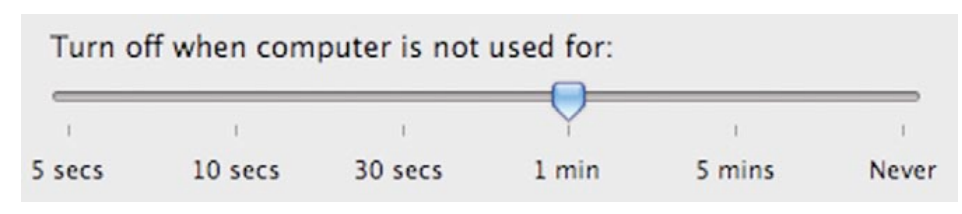

Слика 15 - Пример за кориснички интерфејс каде е применет Гешталт принципот на континуитет

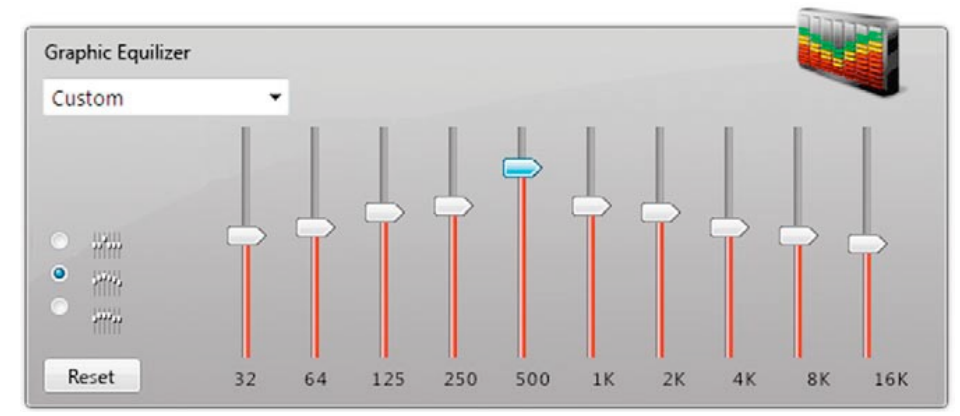

Слика 16 - Пример за кориснички интерфејс каде е применет Гешталт принципот на континуитет

Гешталт принципот на затвореност е поврзан со принципот на континуитет. Овој принцип искажува дека нашиот систем за вид автоматски се обидува да затвори отворени фигури за истите да бидат перципирани како цели објекти отколку како одвоени делови. 


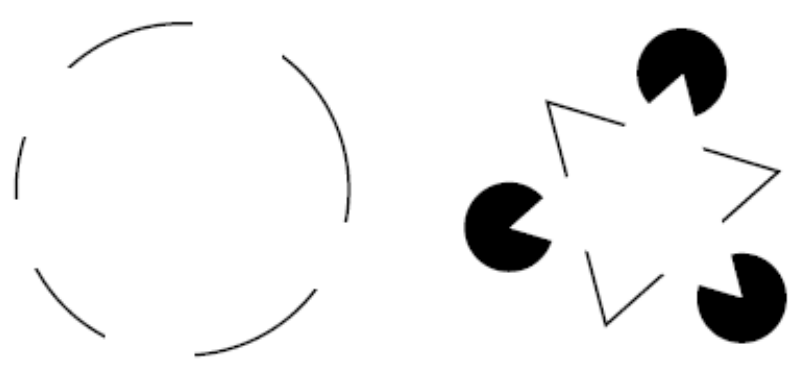

Слика 17 - Илустрации на Гешталт принципот на затвореност

Принципот на затвореност често се применува во дизајнот на графичките кориснички интерфејси. На пример, кај икони кои во себе содржат повеќе објекти поставени на куп. Доволно е да се прикаже еден објект и краевите на другите поставени позади него за да се натераат корисниците да го перципираат купот објекти како целина.

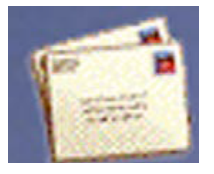

Слика 18 - Пример за икона каде е применет Гешталт принципот на затвореност

Гешталт принципот на симетрија искажува дека имаме тенденција да анализираме сложени сцени на начин кој би ја намалил сложеноста. Податоците во нашето визуелно поле вообичаено можат да се интерпретираат на повеќе начини, но нашиот вид автоматски ги организира и интерпретира податоците за да се поедноставни и симетрични. 


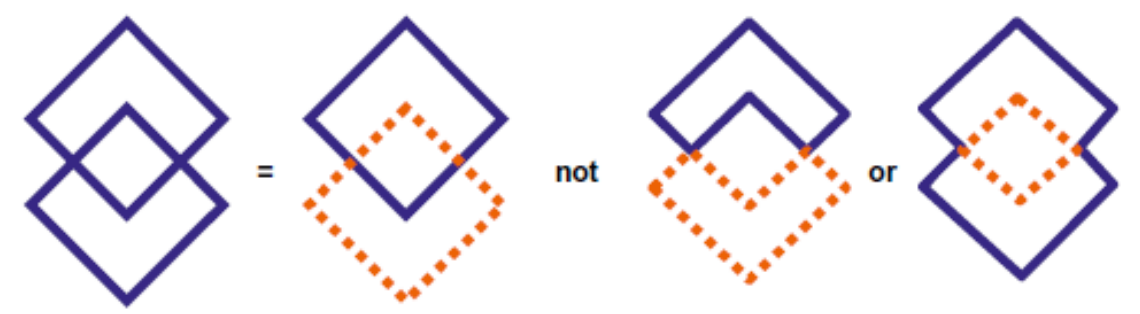

Слика 19 - Илустрација на Гешталт принципот на симетрија

Во печатените медиуми или на компјутерските екрани, ослонувањето на нашиот систем за вид на принципот на симетрија може да се искористи за да се претстават тродимензионални објекти на дводимензионален медиум.

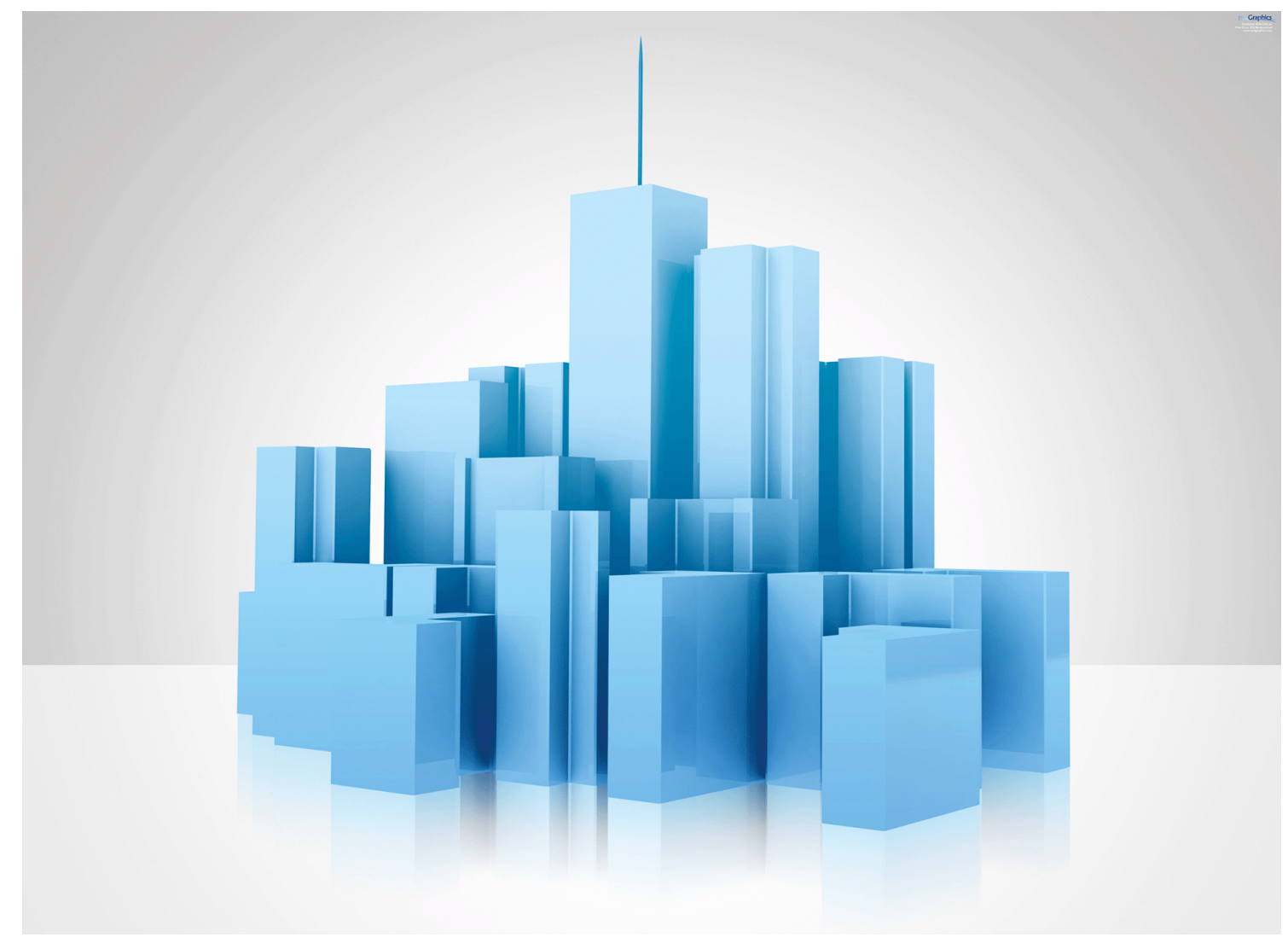

Слика 20 - Пример за графички дизајн каде е применет Гешталт принципот на симетрија 
Следниот Гешталт принцип кој опишува како нашиот систем за вид ги структурира податоците кои ги добива е наречен облик/позадина. Овој принцип искажува дека нашиот ум го издвојува визуелното поле во облик (преден план) и позадина (заден план). Предниот план е содржан од оние елементи на сцената кои се објекти на нашето примарно внимание, додека позадина претставува сѐ останато. Во дизајнот на кориснички интерфејси и веб дизајнот, принципот на облик/позадина често се користи за да се остави некаков впечаток преку позадината зад главната содржина која се прикажува. Во ваков случај позадината вообичаено содржи одредена информација, на пример одредена локација, лого на некој бренд и слично, сѐ со цел да се потпомогне процесот на перцепција на главната содржина.

\section{Ande Documenting the HIV/AIDS Crisis in Sub-Saharan Africa Photos Photographs by Karen Ande 1 EVENTS TAKB ACTION

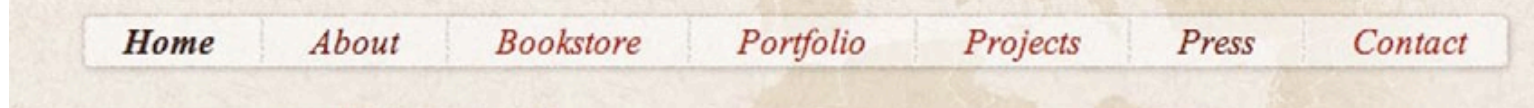

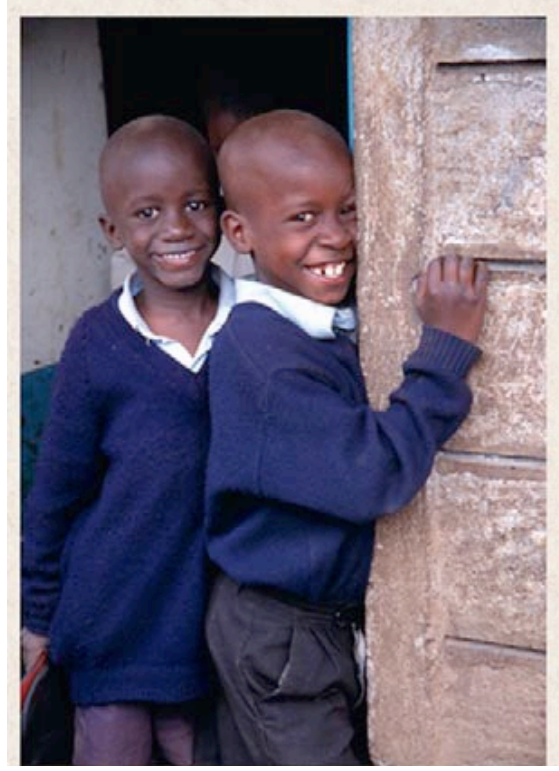

"These are the faces of children and their families living in a world of AIDS. Their spirit, their determination, and their resilience inspire all of us to join their fight. We are one world, and these children are our children, their destiny is our destiny. Each of us can make a difference." - Archbishop Desmond Tutu

\section{Abundance and Chickens July 4 th, 2008}

Journalist Ruthann Richter and I met Joseph and William one morning in their two-room home in Naivasha, Kenya. Their rented house for which they paid \$15/month was simple, unpainted wood. The floor was dirt and the furnishings included chairs, a bed separated from the rest of the house by a torn sheet, a kerosene burner and shelves that contained pots, plastic utensils and a flowered teakettle.

\section{Слика 21 - Пример за веб страница каде е применет Гешталт принципот облик/позадина}




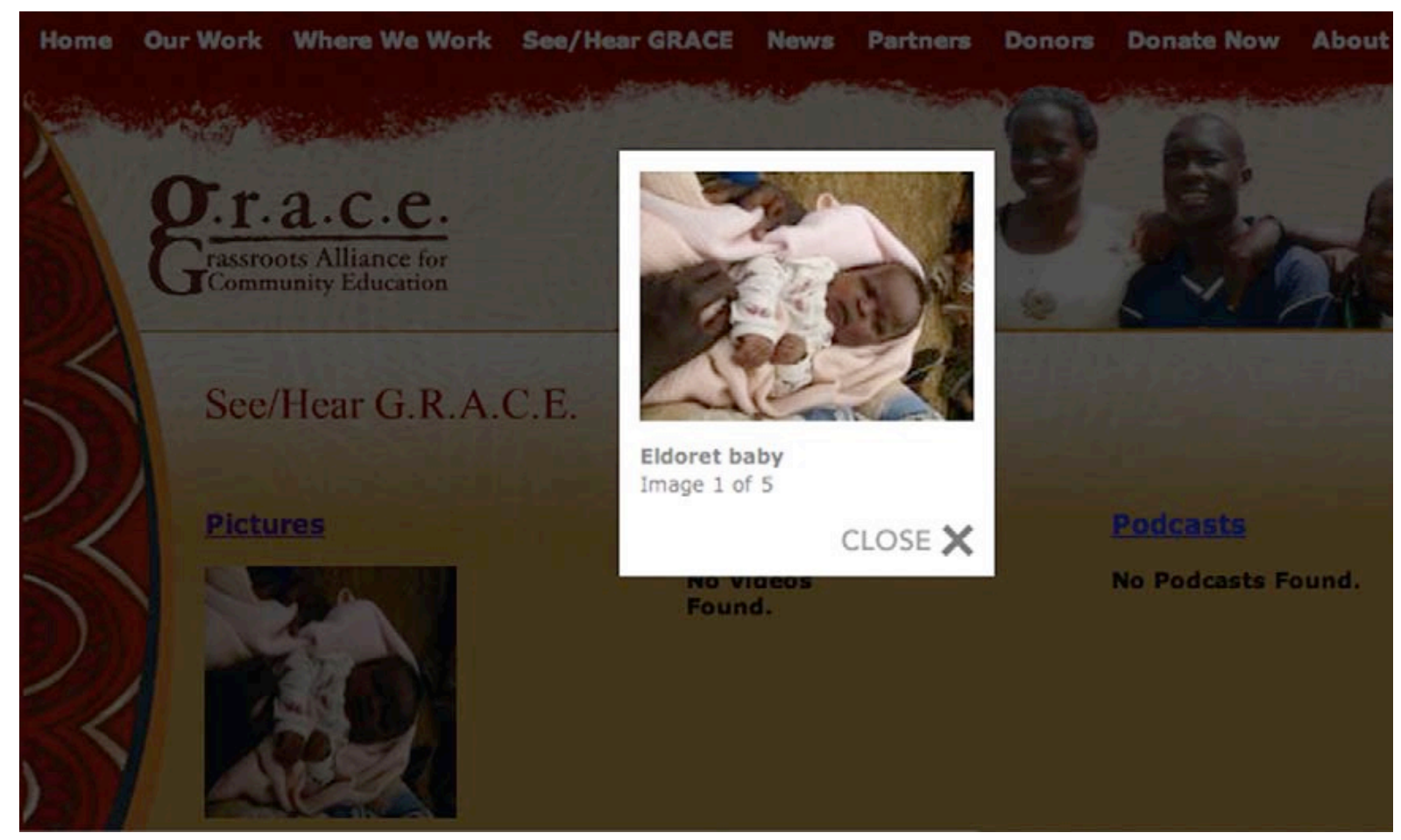

Слика 22 - Пример за веб страница каде е применет Гешталт принципот облик/позадина

Но, овој принцип често се користи и за да се истакне одредена информација врз останатата содржина. Така, содржината која претходно била во преден план т.е. во фокусот на вниманието на корисникот привремено преминува во заден план, за новата информација да биде претставена во преден план одреден краток период. Овој пристап вообичаено е подобар отколку привремено да се замени старата информација со нова информација, бидејќи овозможува контекст кој помага да се задржат корисниците ориентирани во однос на нивното место во интеракцијата. 
Претходните шест Гешталт принципи се однесуваа на перцепцијата на статички фигури и објекти. Последниот Гешталт принцип, принципот на поврзаност, се однесува на подвижни објекти. Овој принцип е поврзан со принципот на блискост и сличност, исто како и во тие случаи и во овој се разгледува перципирањето на објектите како групи или поврзани објекти. Принципот на (заедничка судбина) поврзаност искажува дека објектите кои се движат заедно се перципираат како групирани или поврзани.

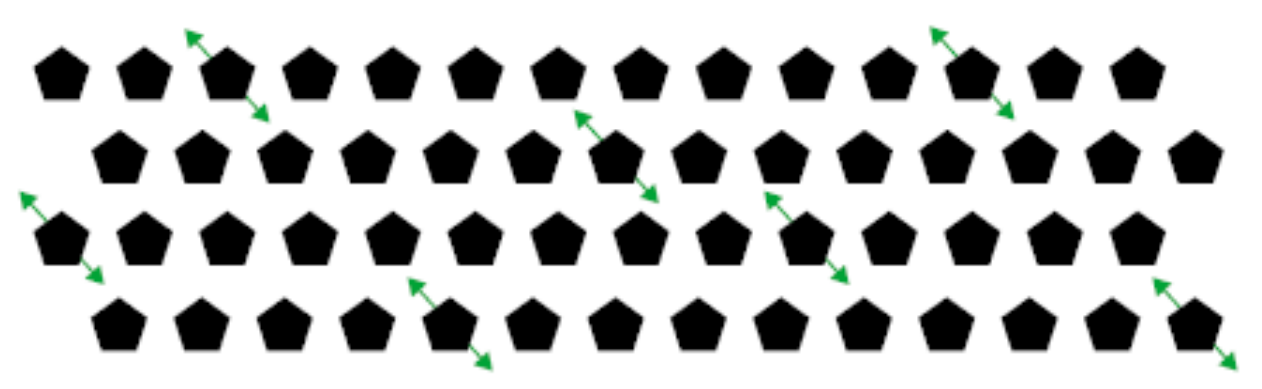

Слика 23 - Илустрација на Гешталт принципот поврзаност

Се разбира, во пракса, Гешталт принципите се применуваат заедно, а не посебно (изолирано). На пример, типичната работна околина на Мас оперативниот систем вообичаено опфаќа шест од седумте принципи опишани погоре (исклучувајќи го принципот на (заедничка судбина) поврзаност): блискост, сличност, континуитет, затвореност, симетрија и облик/позадина. 


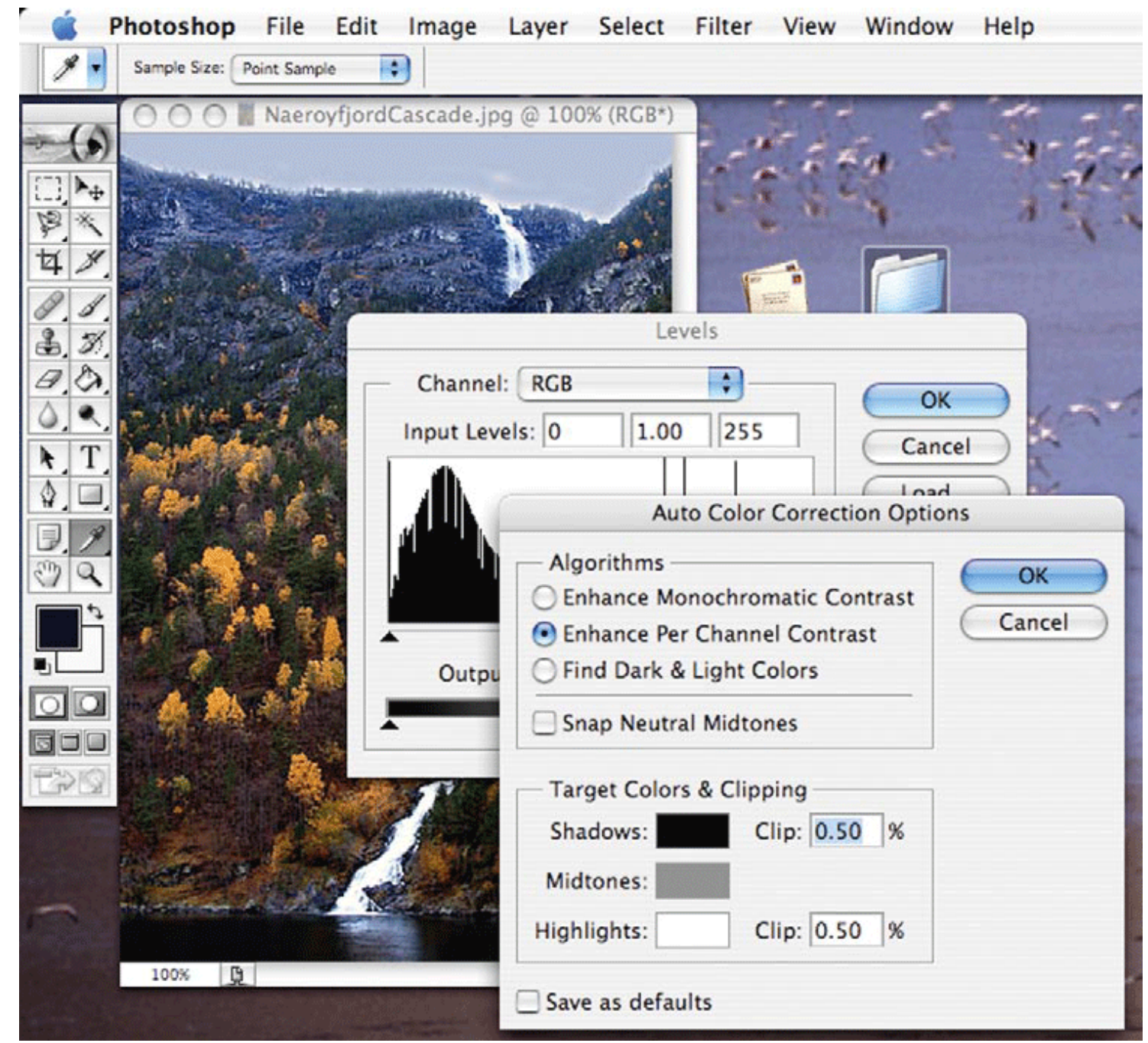

Слика 24 - Пример за работна околина каде се применети повеќе Гешталт принципи заедно

Што се однесува до примената на принципот на (заедничка судбина) поврзаност, тој вообичаено се искористува во комбинација со принципот на сличност кај работните околини кога корисникот избира неколку датотеки или папки и ги влече како група на некоја нова локација. 


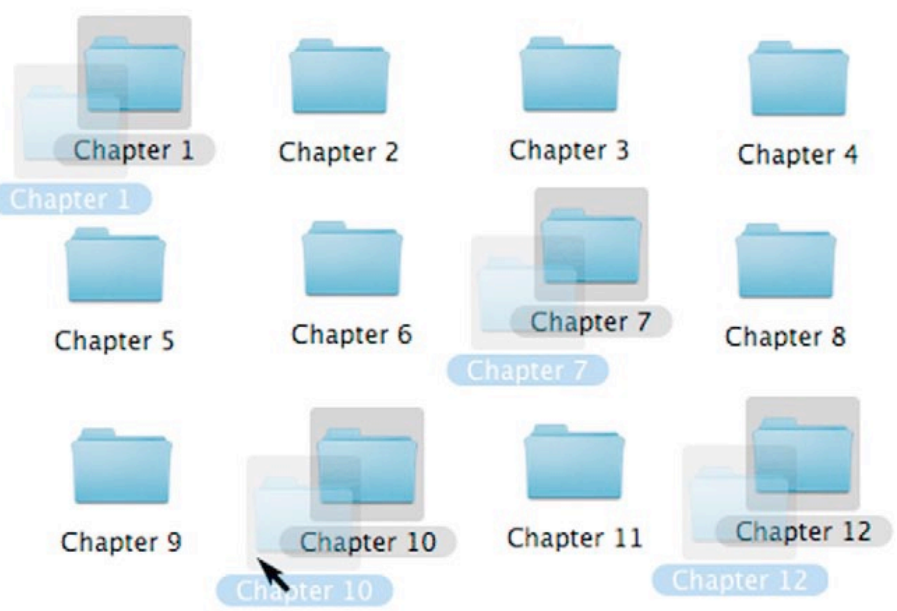

Слика 25 - Пример за работна околина каде е применет Гешталт принципот поврзаност

Во секој случај, треба да се напомене дека при употребата на сите овие Гешталт принципи одеднаш може да се создаде ненамерна визуелна поврзаност во одреден дизајн. Откако ќе се дизајнира екранот, препорачана практика е да се погледне со секој Гешталт принцип в предвид за да се установи дали дизајнот предлага било каква поврзаност помеѓу елементи која не е предвидена. 


\section{2. Психологија на бои}

Бојата е првото нешто што се забележува и често е последното нешто што се заборава, затоа изборот на истата е доста важен процес. Психологијата на боите сама по себе не е егзактна наука, поедини психолози имаат сопствени толкувања, а дополнително на тоа значењето на боите примарно се разликува во културите. Следствено нема точни или погрешни бои. Сепак, постојат некои општо прифатени ставови, односно психолошки асоцијации, кои луѓето од западните култури ги имаат прифатено. Бидејќи низ годините се покажало дека луѓето повеќе реагираат на невербални укажувања отколку на вербални, правилно избраните бои може да предизвикаат подобра реакција од други кај целната група корисници.

Имено, боите имаат значително влијание врз перцепцијата за компанијата и самиот избор на клиентот. Но, при изборот на боја за одредена целна група корисници треба да се има предвид дека постојат и некои преференции ${ }^{19}$ во зависност од: полот, годините, едукацијата, општеството (културата и верувањата), човечката психа (асоцијациите од минатото и животните искуства) итн. Процесот на избор на боја, базиран на симболизам, може да се применува на секакви дизајнерски проекти: дизајн на предмети, облека, мебел, лого дизајн, веб дизајн, дизајн на печатени публикации итн. Во веб дизајнот психолошкиот аспект кој го предизвикуваат боите е многу важен. Секој нарачател на веб локација сака со избраните бои да привлече внимание и да предизвика желба кај посетителите за купување на нивните производи или за користење на нивните услуги. Меѓутоа, за изборот да биде навистина успешен треба да се имаат на ум сите аспекти на боите, а не само посакуваните дизајн цели.

Дизајнерите треба да имаат предвид дека нивниот дизајн може да не биде сфатен како што го замислиле. Луѓето имаат различни искуства на веб страниците зависно од боите. Топлите бои често визуелно доминираат и предизвикуваат јаки емоции, па дури и физички реакции (пр. покачен крвен притисок и сл.) кај луѓето. Овие реакции можат да се смират со умерена и промислена примена на ладни или неутрални бои.

\footnotetext{
${ }^{19} \mathrm{H}$. Lim, The Effect of Color in Web Page Design, University of Texas, Austin, TX, USA.
} 
Жолтата боја ја користат забавните и пријателски настроени брендови. Истото важи и за компаниите кои сакаат да испратат порака на радост и оптимизам. Меѓутоа, во некои култури жолтата боја ја означува кукавичноста, во Јапонија пак означува храброст, во Индија е боја на трговците, а во Египет пак е боја на жалост. Поради јаката видливост, општо прифатена е нејзината примена кај знаци кои треба да укажат на одредена претпазливост. Ова е случај и во веб дизајнот, често жолтата боја се користи за известувања, елементи или страници каде се укажува на одредена ситуација каде е потребно да се обрне внимание.

Најжешката од топлите бои е црвената боја. Таа пред сѐ симболизира моќ и страст. Докажано е дека може да предизвика физички манифестации кај човекот, како што се забрзана респирација, покачен крвен притисок и слично. Меѓутоа, опфаќа голем опсег на конфликтни емоции, почнувајќи од љубов па сѐ до насилство и војна. Па така, појавата на црвенило на образите може да биде предизвикана од силни чувства на љубов или пак на лутина. Во некои источни земји невестите носат црвена боја, во Кина означува радост и просперитет, додека во Јужна Африка таа е боја на жалост и тага. Најчесто оваа интензивна боја се користи за привлекување внимание и преземање одредена акција, бидејќи асоцира на опасност. Во контролирани дози има многу подобар ефект заради нејзиниот интензитет. Токму затоа, највообичаено во веб дизајнот се користи кај формуларите за да се означат погрешно внесените информации.

Кога е потребно да се симболизира здравје, младост, свежина, обнова, животна околина и екологија се употребува зелената боја, бидејќи ја има во изобилие во природата. Гледано од друга страна, пак, оваа боја може да се поврзе и со парите и зависта. Меѓутоа, во веб дизајнот вообичаено се користи за да се означат потврдни пораки од најразличен тип, а најчесто за добро внесени податоци во формулари.

Смирените и логични компании ја користат сината боја. Оваа боја најчесто се поврзува со умот и затоа клиентите ја поврзуваат со интелигенција и комуникација. Но, со избирање на погрешната нијанса на сина боја може да се долови непосакуван впечаток на далечност и недостижност за клиентите. За разлика од црвената боја која предизвикува силни емоции, оваа боја делува смирувачки кога се гледа и помага за заспивање. Но токму заради тоа со преголема примена може да се предизвикаат 
тажни емоции и да делува депресивно. Сината боја, исто така, симболизира единство и интегритет. Скоро за сите е допадлива и не случајно е тоа што главните социјални медиуми како што ce: Facebook, Twitter и LinkedIn ја користат оваа боја како примарна во нивните брендови. Таа може да биде лесна и пријателска или силна и посветена. Сината боја изразува важност и доверба без да предизвика вознемирување, така што темно сината боја вообичаено се применува на униформи како што се полициските или авијациските. При изборот на оваа боја за примена во веб дизајнот, генерално, не може да се погреши заради нејзината допадливост и сериозноста која истовремено ја прикажува.

Компаниите кај кои е присутна виолетовата боја сакаат да се препознаени како луксузни, квалитетни и несекојдневни. Оваа боја во многу култури, традиционално, се поврзува со кралство. Виолетови свечени облеки носеле луѓе со кралски или висок благороднички статус. Затоа таа асоцира на отменост, достоинство, мистичност и спиритуализам. Употребата на виолетовата и розовата боја во веб дизајнот е најчеста кај веб локации кај кои целната група корисници претежно се од женскиот пол.

Кога компаниите сакаат нивните брендови да бидат препознаени како ексклузивни и елегантни користат црна боја. Слично на виолетовата и оваа боја се перципира како луксузна, а кога се применува правилно испраќа моќна порака на софистицираност и сериозност. Често се употребува за означување мистериозност или негативност во некои случаи, а во суштина е доста конзервативна и конвенционална боја. Кај повеќето западни култури оваа боја симболизира тага, но многу млади луѓе ја доживуваат како бунтовна боја. Кај облеката предизвикува визуелен ефект на виткост, а кога се применува во простор, оваа боја како и другите темни бои, создава впечаток дека просторијата е помала. Но, добра е како позадина на цртеж, слика или пак фотографија, бидејќи ги истакнува елементите во преден план. Добро се комбинира со скоро сите бои и креира ефект дека другите бои се посветли, но во комбинација со темни нијанси делува многу безлично. Кога е целта да се презентира нешто како гламурозно се користи комбинација на црна и златна боја. Златната боја секогаш се поврзува со богатство, екстраваганција, дури и просперитет. Примената на црната боја во веб дизајнот е најразлична, меѓутоа најчесто на најмногу веб локации се сретнува како позадина при прегледување на слики. Ова е со цел да се даде на знаење на 
корисникот дека не посетува друга посебна веб страница, туку користи дополнителна функционалност на постојната.

Сивата е доста урамнотежена, неутрална боја, која ретко предизвикува емоции. Во зависност од нијансата, може да предизвика различни ефекти. Потемните нијанси имаат слични ефекти како црната боја, а светлите како белата боја. Често пати сивата боја асоцира на формалност. Во веб дизајнот оваа боја наоѓа огромна примена како позадина на веб страниците. Неутралноста на оваа боја дозволува посетителите подолго време да ја прегледуваат веб страницата без да имаат потешкотии, што може да биде случај доколку како позадина се искористи бела боја.

Белата боја асоцира на добрина и искреност. Меѓутоа, најпрепознаена е како боја која симболизира чистота заради нејзината примена во болниците и кај униформите на докторите и медицинските сестри. Во западните култури се поврзува и со невестинска облека, но на истокот го има комплетно спротивното значење и е боја на жалост. Во некои случаи, кога е потребно да се прикажат останатите бои како позначајни и поголеми, белата позадина е решение. Иако може да се комбинира со сите бои, оваа боја може да предизвика главоболки, бидејќи во суштина е потполна светлина. Дополнително, премногу бело осветлување може да делува и заслепувачки на човековото око. Заради овие причини таа се употребува контролирано во веб дизајнот и претежно се користат многу светли нијанси на сива боја како нејзина замена.

Стабилноста, доверливоста и сигурноста се поврзуваат со кафената боја. Овие асоцијации можат да се каже дека потекнуваат од присуството на оваа боја во природата, кај почвата и дрвјата. Иако, првата асоцијација кога ќе се погледне оваа боја скоро секогаш е чоколадото. Во суштина е неутрална боја, меѓутоа луѓето некогаш ја поистоветуваат со топла. Кафената боја се применува за поттикнување чувство на топлина, припадност и чесност. Светлите нијанси на кафена можат да послужат како одлична позадина која дозволува останатите применети бои да наликуваат посветло и побогато, додека темните тонови можат да се користат како замена за црната боја. Можеби за некои луѓе делува досадно, но заради нејзината можност лесно да се комбинира со неутралните бои таа наоѓ примена во одредени елементи и детали во веб дизајнот. 


\section{3. Дијаграм на Гутенберг}

Дијаграмот на Гутенберг ${ }^{20}$ ја опишува генералната шема која ја следат очите кога гледаат во еднакво дистрибуирана хомогена информација односно содржина на некаков екран. Овој дијаграм исто така е познат и како Z шема на процесирање. Тој го дели екранот на четири квадранти:

- Примарно видно поле во горниот лев агол

- Неискористено поле каде човекот има јак фокус во горниот десен агол

- Неискористено поле каде човекот има слаб фокус во долниот лев агол

- Крајно поле во долниот десен агол

Западните читатели, природно, започнуваат со примарното видно поле и се движат надолу по екранот т.е. веб страницата со серии на замавнувања кон крајното поле. Секое замавнување започнува од оската на ориентација, која вообичаено е хоризонтална линија креирана од редови текст, некои подредени елементи (на пример слики итн.) или експлицитни сегменти и продолжува во правец од лево кон десно. Неискористените полиња лежат надвор од оваа патека и добиваат минимално внимание (од каде и потекнува нивниот назив), освен ако не се визуелно потенцирани. Тенденцијата да се следи оваа патека метафорички е припишана на гравитацијата на читањето - од лево кон десно и од горе кон доле, која природно е стекната со текот на времето.

\footnotetext{
${ }^{20}$ https://medium.com/user-experience-3/the-gutenberg-diagram-in-web-design-e5347c172627
} 


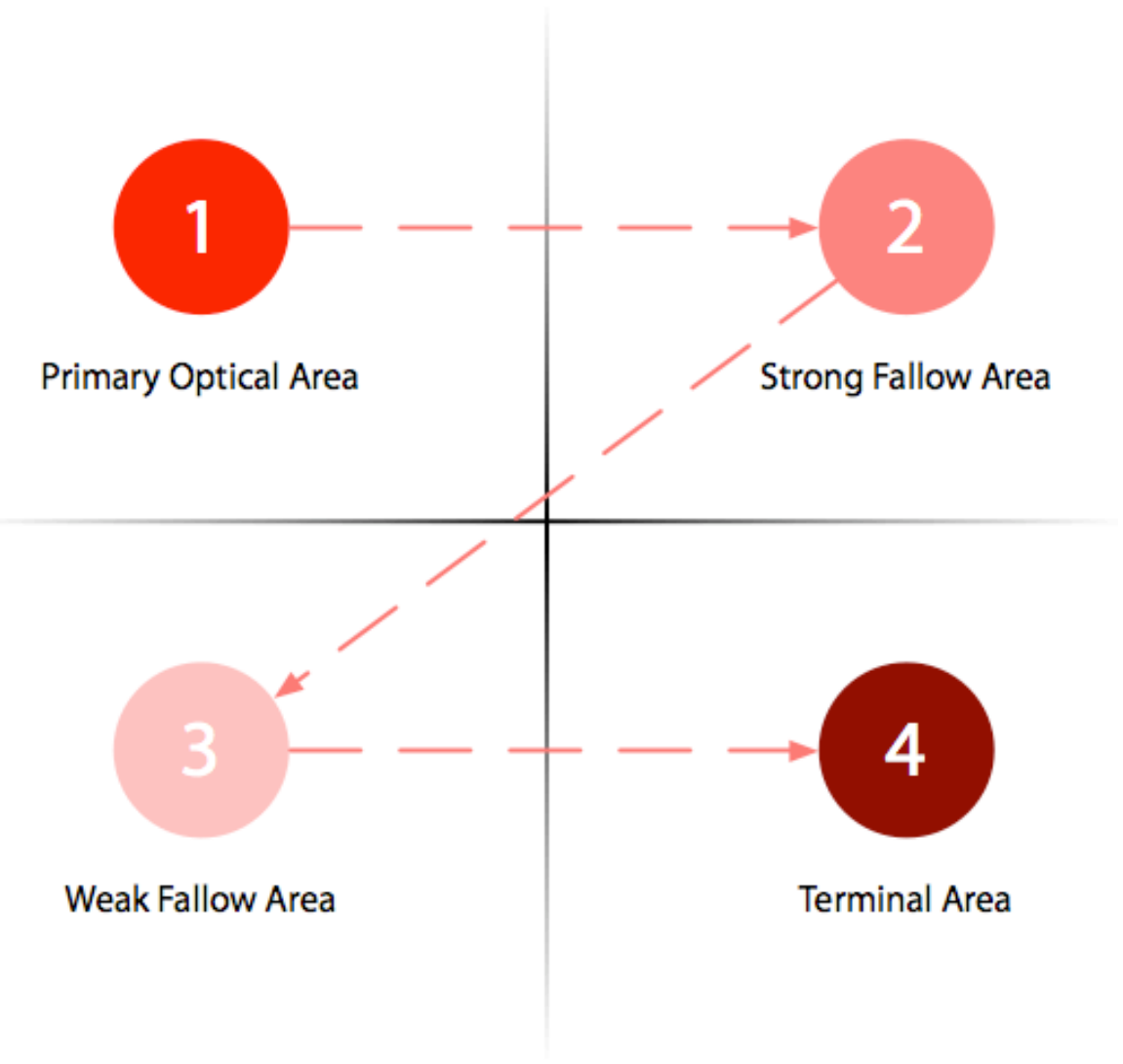

Слика 26 - Дијаграм на Гутенберг

Дизајните кои го следат принципот на овој дијаграм, кои се во хармонија со гравитацијата на читањето и кои ги враќаат читателите во логична оска на ориентација го подобруваат ритамот на читање и разбирањето на содржината. Затоа, распоредот на содржините треба да биде соодветен во зависност од нивната важност. Оние кои се од особен интерес треба да се постават во делот каде човекот најдобро ќе ги забележи. Често во примарното видно поле се поставуваат логото и називот на компанијата, а во крајното поле информациите за контакт.

Meŕyтоа, дијаграмот на Гутенберг повеќе го опишува предвидливото движењето на очите во одредени случаи - кога станува збор за долги текстови и еднакво распространети и хомогени содржини на екраните. Во сите останати случаи, рамнотежата на дизајнот и целокупната композиција го диктираат движењето на очите и можат поинаку да го насочат. 
Генерално, корисниците набрзина ги прегледуваат веб страниците и имаат време да прочитаат само четвртина од текстот кој е прикажан на страниците кои ги посетуваат. Според едно истражување ${ }^{21}$ корисниците често ги напуштаат веб страниците за 10-20 секунди. Па така, доколку текстот не е многу јасен и концизен, малку од она што е прикажано на веб страницата ќе допре до посетителите. Но, заради тоа што корисниците се човечки суштества, нивните однесувања многу варираат и поради тоа не можат целосно да се забележат со единствен број. Следствено, во зависност од интересот кој го предизвикуваат поединечните страници (со нивната содржина) кај корисниците, нивниот престој на дадената страница може да биде и подолг. Бидејќи постојат многу веб локации и сите навистина многу се разликуваат во нивниот квалитет, поретко треба да се очекува дека корисниците ќе се задржат подолго само на една веб локација. Но, кога ќе проценат дека станува збор за вредна веб локација, тие можат многу лесно да станат нејзини лојални посетители.

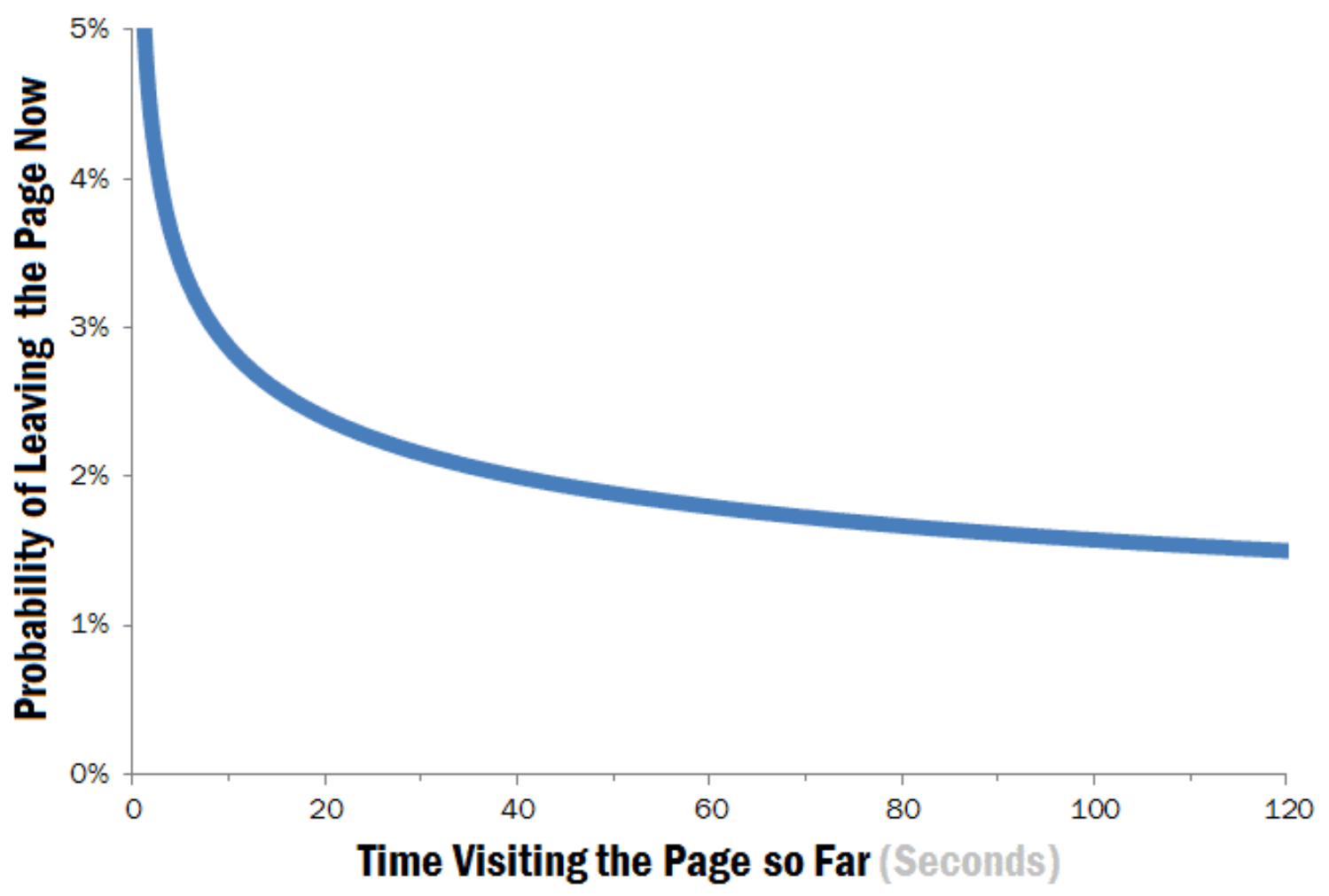

Графикон 1 - Резултат од истражувањето на престојот на корисниците на веб страниците

\footnotetext{
${ }^{21}$ http://www.nngroup.com/articles/how-long-do-users-stay-on-web-pages/
} 
Јасно е од графиконот дека првите 10 секунди од посетата на веб страницата се критични за одлуката на посетителите да останат или заминат од истата. Веројатноста за заминување е многу висока за време на овие први неколку секунди, затоа што корисниците се доста скептични поради тоа што до тогаш претрпеле/прегледале повеќе последователни лошо дизајнирани веб страници (па се водат од нивното минато искуство и прават делумно неосновани претпоставки). Луѓето знаат дека повеќето веб страници се бескорисни и се однесуваат соодветно за да избегнат понатамошно губење на своето време на лоши веб страници. Дури и по првите 10 секунди, откако корисниците ќе ја разгледаат веб страницата, тие сеуште се подложни на заминување во последователните 20 секунди од нивната посета. Само откако посетителите ќе отседат на страницата околу 30 секунди може да се забележи стабилизирање на заминувањето. Луѓето и понатаму продолжуваат да заминуваат секоја секунда, но со многу помала стапка во однос на претходно. Од сето ова може да се заклучи дека доколку се натераат посетителите да останат на веб страницата половина минута, постои добра шанса да останат уште подолго - често две минути или повеќе.

Перципирањето структура во нашата околина ни помага да создадеме за брзо време смисла за објектите и настаните. Кога корисниците прегледуваат одредена веб локација не ги набљудуваат екраните внимателно и не го читаат секој збор. Напротив тие брзо прегледуваат барајќи ја потребната информација. Кога информациите се презентираат на краток, структуриран начин полесно е корисниците да прегледаат и разберат.

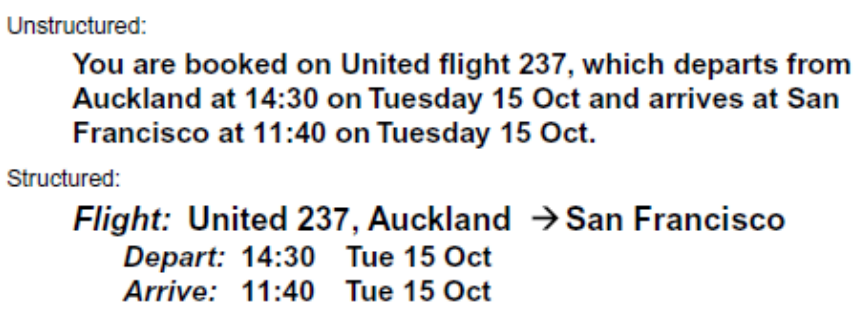

Flight: United 237, Auckland $\rightarrow$ San Francisco

Depart: 14:30 Tue 15 Oct

Arrive: 11:40 Tue 15 Oct

Слика 27 - Пример за неструктуриран и структуриран текст 
На претходната сликата е даден пример преку две прикажувања на една иста информација, за резервација на авионски билет. Првото прикажување е преку неструктуриран прозаичен текст, додека второто прикажување е преку структуриран текст во кратка форма. Структурираното прикажување на резервацијата може да биде прегледано и разбрано за далеку пократко време отколку прозаичното прикажување.

Една од најважните цели 22 во структурирањето на прикажувањето на информациите е овозможувањето визуелна хиерархија, односно уредување на информациите кое:

- Ги дели информациите во засебни области и ги дели поголемите области на дополнителни подобласти

- Ги означува сите области и подобласти видно и на начин кој јасно ја идентификува содржината

- Ги претставува областите и подобластите со видлива хиерархија, со позначајно прикажување на областите на повисоките нивоа отколку оние на пониските нивоа

Визуелната хиерархија им овозможува на корисниците, кога прегледуваат информации, инстантно да го издвојат она што е релевантно за нивните цели од она што е ирелевантно и да го фокусираат нивното внимание на потребните информации. Тие го пронаоѓаат она што им е потребно побрзо, бидејќи прескокнуваат сѐ останато. Сето ова може да се забележи во примерот даден на следната слика.

\footnotetext{
22 J. Johnson, Designing with the mind in mind, Morgan Kaufmann Publishers, Burlington, MA, USA, 2010. (p.30)
} 
Create a Clear Visual Hierarchy

Organize and prioritize the contents of a page by using size, prominence, and content relationships. Let's look at these relationships more closely. The more important a headline is, the larger its font size should be. Big bold headlines help to grab the user's attention as they scan the Web page. The more important the headline or content, the higher up the page it should be placed. The most important or popular content should always be positioned prominently near the top of the page, so users can view it without having to scroll too far. Group similar content types by displaying the content in a similar visual style, or in a clearly defined area.

\section{Create a Clear Visual Hierarchy}

Organize and prioritize the contents of a page by using size, prominence, and content relationships.

Let's look at these relationships more closely:

- Size. The more important a headline is, the larger its font size should be. Big bold headlines help to grab the user's attention as they scan the Web page.

- Prominence. The more important the headline or content, the higher up the page it should be placed. The most important or popular content should always be positioned prominently near the top of the page, so users can view it without having to scroll too far.

- Content Relationships. Group similar content types by displaying the content in a similar visual style, or in a clearly defined area.

\section{Слика 28 - Пример за текст без и текст со визуелна хиерархија}

Визуелната хиерархија е исто така од голема важност и кај интерактивните контролни панели и формулари. Тоа може да се увиди доколку се споредат дијалог прозорците на двата музички софтвера кои се дадени на сликите во продолжение. Дијалог прозорецот на софтверот Band-in-a-Box има слаба визуелна хиерархија, правејќи го пронаоѓањето одредени поставки потешко за корисниците. Спротивно на тоа, контролниот панел на софтверот GarageBand има добра визуелна хиерархија, така што корисниците брзо и едноставно можат да ги најдат поставките кои им се потребни.

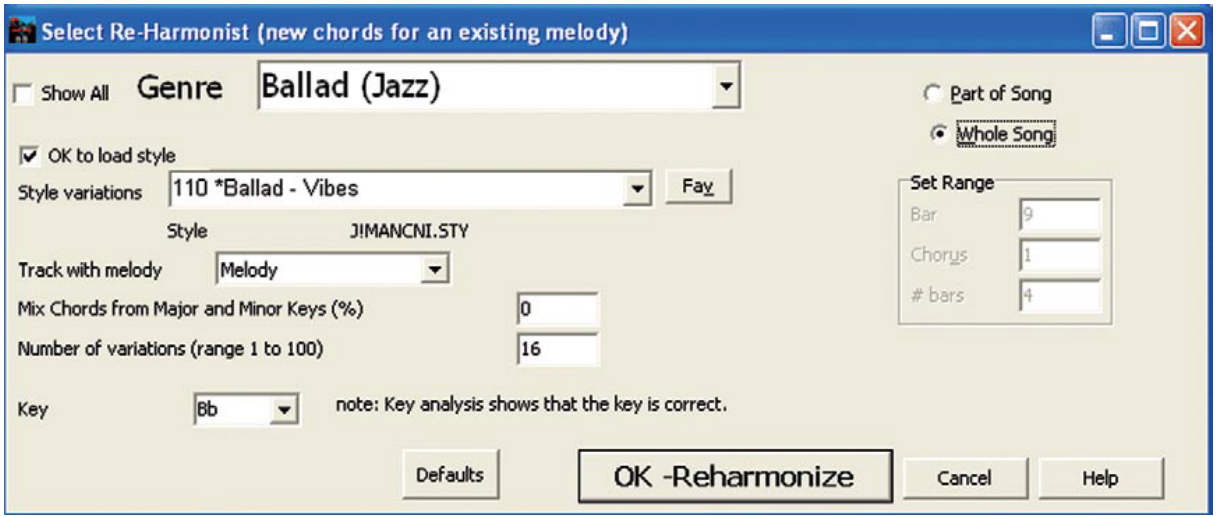

Слика 29 - Пример за кориснички интерфејс со слаба визуелна хиерархија 


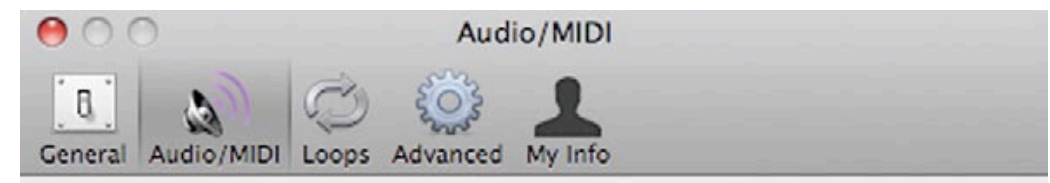

Audio Output: System Setting

Audio Input: System Setting

Optimize for: $\bigcirc$ Maximum number of simultaneous tracks Large buffer size.

$\odot$ Minimum delay when playing instruments live Small buffer size.

MIDI Status: 0 MIDI Input(s) detected

Keyboard Sensitivity:

Less Neutral More
Drag the slider to adjust the velocity
level of notes you play.

Слика 30 - Пример за кориснички интерфејс со добра визуелна хиерархија

Дополнително на дизајнерските грешки кои можат да го отежнат читањето, многу софтверски кориснички интерфејси прикажуваат повеќе текст од она што е неопходно, создавајќи им потреба на корисниците да читаат повеќе од потребното. 


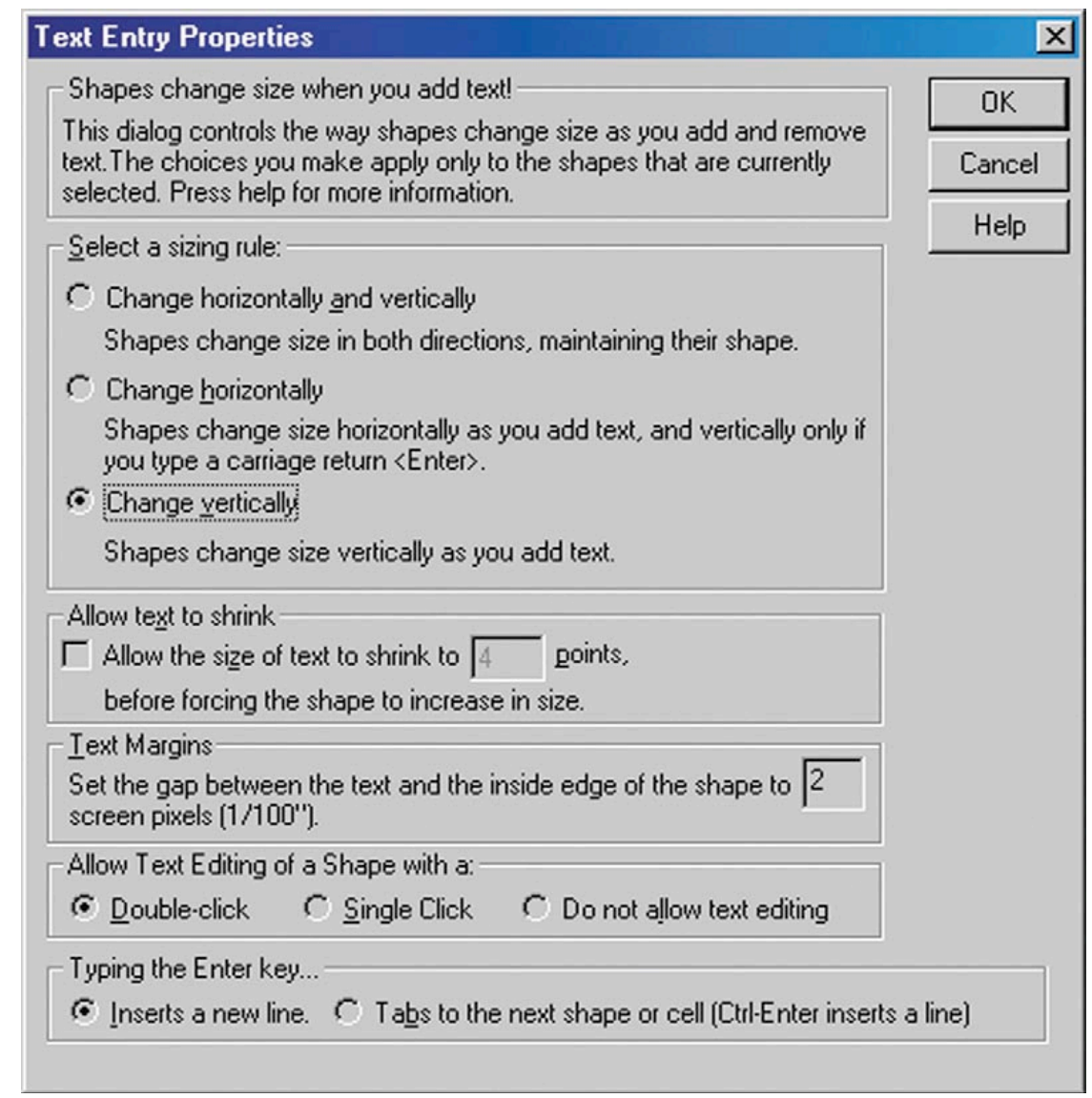

\section{Слика 31 - Пример за кориснички интерфејс со премногу текст}

Најчесто и нема потреба да се пишува долг текст за да им се објасни на корисниците сѐ јасно и детално. Може да се објасни сѐ и да се постигне истиот ефект со краток концизен текст. Непромисленото пишување или прикажување на текст може кај корисниците да ја редуцира брзината на читање како и разбирањето на содржината општо. Еден од честите начини како софтверите и веб страниците го нарушуваат целиот процес на читање е употребата на непознат вокабулар за целната група корисници. Затоа, дизајнерите би требало да го тестираат дизајнот на целната група корисници за да бидат сигурни дека корисниците можат да го прочитаат целиот неопходен текст брзо и без потешкотии. Некои тестирања можат да се спроведат во раните фази на дизајнот, користејќи некаков вид на прототипи, но во секој случај треба да се тестира и во крајните фази. За среќа во веб дизајнот промените кои треба да се направат во последен момент пред да се објави веб локацијата, а кои се однесуваат на големината на фонтот и форматот на текстот, вообичаено се доста едноставни. 
Исто така, при брзо читање нашите очи се навикнати да се вратат на истата хоризонтална позиција и да се поместат за еден ред вертикално надолу. Во случај кога текстот е центриран или подреден од десната страна, секоја линија започнува од различна хоризонтална точка. Со тоа автоматското движење на очите ги враќа нашите очи во погрешната позиција, па заради тоа треба свесно да го насочуваме нашиот поглед на конкретниот почеток на секој ред. Со самото ова ние сме исфрлени од автоматизмот при читањето и значајно сме успорени во целиот процес.

\section{Exclusive Buyer Agency Offer}

(No Cost) Service to Home Buyers!

Dan and Lida want to work for you if:

Would you like to avoid sellers agents who are pushing, selling, and trying to make sales quotas?

Do you want your agent to be on your side and not the sellers side?

Do you expect your agent to be responsible and professional....?

If you don't like to have your time wasted, Dan and Lida want to work for you....

If you understand that everything we say and do, is to save you time, money, and keep you out of trouble.... and if you understand that some agents income and allegiances are in direct competition with your best interests....

-and if you understand that we take risks, give you $24 / 7$ access, and put aside other paying business for you...

-and if you understand that we have a vested interest in helping you learn to make all the right choices...

- then, call us now, because Dan and Lida want to work for you!!

\section{Слика 32 - Пример за чентриран текст}

Очигледно е дека целта на секој дизајнер треба да биде насочена кон потпомагање на процесот на читање. Дизајнот треба, пред сѐ, брзо и ефикасно да комуницира за каква веб локација станува збор и да демонстрира како може да му биде од корист на корисникот. Затоа дизајнерите треба да се придржуваат до следните насоки²3:

- Создадете содржина која е впечатлива, јасна и описна, концентрирана на придобивките наспроти карактеристиките.

- При описот на производи/услуги дадете краток преглед на производот/услугата и дозволете му на корисникот да добие повеќе детали доколку посака.

\footnotetext{
${ }^{23}$ J. Johnson, Designing with the mind in mind, Morgan Kaufmann Publishers, Burlington, MA, USA, 2010. (p.50)
} 
- При давањето инструкции користете најмала можна количина текст кој ќе ги спроведе корисниците до нивните цели.

- Уредете го текстот за да создадете визуелна хиерархија за да се потпомогне едноставното прегледување преку: употреба на наслови, листи, табели и визуелно изразени зборови

- Користете ограничен и високо конзистентен вокабулар, кој понекогаш се нарекува и чист јазик или поедноставен јазик, наместо стручни термини или пак жаргон. Користејќи (едноставен) разбирлив јазик се намалува когнитивниот замор, правејќи ја целата содржина поверодостојна и поубедлива.

- Демонстрирајте ја (точноста на информациите кои се презентирани, како и кредибилноста на компанијата) довербата во компанијата и експертизата на вработените, професионализмот или воопшто дека веб локацијата е водена од реални луѓе т.е. дека навистина постои компанијата. За таа цел потребни се сведоштва на клиенти, листи на клиенти или соработници (и нивни логоа), сертификати за безбедност (особено кај веб локациите кај кои може да се изврши плаќање преку Интернет), разни акредитации, можноста за разговор во живо со некој од вработените, бројачи на споделувања на социјалните мрежи, поставување контакт информации (адреса, телефонски број и сл.). 


\section{4. Влијанието на културите}

Денес, веб локациите можат да бидат посетени од луѓе од многу различни земји. Земајќи предвид дека луѓе од различни култури може да имаат различни стратегии на употреба на дадена веб локација, една ефективна веб локација побарува воочување на разликите и дизајнирање за да ги опслужи потребите на луѓето со различни културни позадини. Веб локацијата игра улога на интерфејс, овозможувајќи им на луѓето да бидат во интеракција со Интернетот. Следствено, добрите интерфејс дизајни можат да го зголемат капацитетот на корисникот за обработка на информациите дадени на веб локацијата. Истражувања 24 на културни разлики од различни перспективи, вклучувајќи лингвистика, културни шаблони, модели на култури и когнитивни стилови, допринеле кон крос-културниот веб дизајн. Конечно, веб дизајнот треба да го опслужи типичниот режим на перцепција, размислување, помнење и решавање проблеми на една индивидуа за да се истакне употребливоста.

Nisbett и Norenzayan во нивниот труд „Culture and Cognition“ предложиле когнитивните процеси да се разликуваат според холистички и аналитички перспективи. Западните народи користат аналитички когнитивен стил кој подразбира издвојување на објектот од неговиот контекст (негово категоризирање) и фокусирање на категориите (преку кои се објаснува и предвидува однесувањето на објектот). Од друга страна, источните народи користат холистички когнитивен стил кој има тенденција да гледа на полето (контекстот) како целина и да се фокусира на врските помеѓу објектите и полето. Така, доколку се претпостави дека гледањето веб страници е слично како гледањето слики, источните и западните народи ќе имаат различни шеми и перцепции додека прегледуваат веб страници. Холистички настроените луѓе имаат тенденција да ја согледаат сцената глобално или со други зборови да ги согледаат контекстот и полето како целина. Тие исто така имаат тенденција да се фокусираат на врските помеѓу објектите и полето, што значи дека тие се повеќе зависни од полето. Од друга страна, аналитички настроените луѓе имаат тенденција да го согледаат објектот

\footnotetext{
${ }^{24}$ Y. Dong, K. Lee, A Cross-Cultural Comparative Study of Users' Perceptions of a Webpage, International Journal of Design, Vol.2, No.2, 2008.
} 
одвоено од сцената и имаат тенденција да поделуваат објекти во категории. Аналитички настроените луѓе се понезависни од полето.

Наодите од ова истражување укажуваат дека холистички настроените луѓе и аналитичките луѓе имаат уникатни начини на согледување на веб страниците. Веб дизајнерите треба да се свесни за когнитивните разлики кои постојат помеѓу холистички настроените луѓе $и$ аналитички настроените луѓе $и$ дизајнот на веб страниците треба да биде спроведен соодветно според когнитивниот стил на корисниците за да се подобри перцепцијата и употребата на веб страницата. Бидејќи холистички настроените луѓе имаат тенденција да ја прегледуваат цела страница и нелинеарни шеми на прегледување, содржината може да биде поставена послободно на страницата (споредено со тоа кога се дизајнира за аналитички настроените луѓе). Кога се дизајнира веб страница за овие луѓе, хармонијата помеѓу предниот план и позадината како и врските помеѓу сите области со содржина треба да се земат предвид. Аналитички настроените луѓе имаат тенденција да читаат секвенцијално помеѓу области и да читаат од центарот кон периферијата на страницата, распоредот на сите области со содржина треба да биде внимателно обмислен. Насловите на категориите и елементите на навигацијата треба да бидат именувани што е можно појасно, бидејќи аналитички настроените луѓе имаат тенденција да обратат повеќе внимание на овие елементи и да го добијат целокупниот впечаток за веб локацијата токму од нив. Кога се дизајнираат веб страници за аналитички настроени луѓе треба да се насочат напорите кон дизајнирање на секоја област со содржина засебно и треба да бидат нагласени независните области со содржина. 


\section{4. Ергономски фактори во веб дизајнот}

Интернационалната асоцијација за ергономија (International Ergonomics Association - IEA) ја дефинира ${ }^{25}$ ергономијата како научна дисциплина која се занимава со осознавање на интеракциите помеѓу луѓето и другите елементи на еден систем и професија која ги применува теоријата, принципите, податоците и методите во дизајнот со цел да ја оптимизира човековата благосостојба и целокупната работа на системот. Фокусот на ергономијата е врз примената на знаењето за човечките можности, ограничувања, шеми на однесување и други карактеристики во дизајнот на системите човек-машина. По дефиниција, системот човек-машина претставува систем кој вклучува интеракција помеѓу луѓе и одредени компоненти на системот како што се хардверот, софтверот, задачите, околините и работните структури. Овој систем може да биде едноставен, како на пример рачен алат или може да биде сложен, како на пример компјутерски екран или авијатички систем. Во било кој случај, главната цел²6 на ергономијата е да ги зголеми човечката и системската ефикасност, здравјето, безбедноста, комфорот и квалитетот на живот.

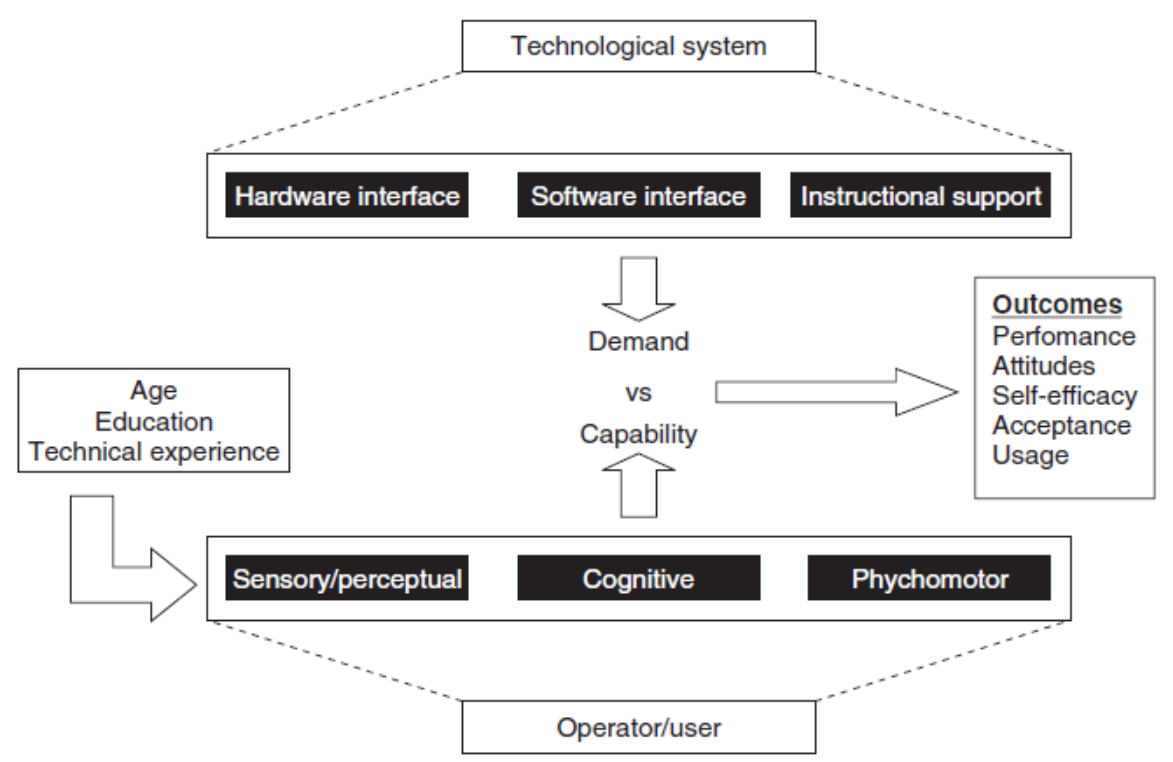

Слика 33 - Шематски приказ на системот човек-машина

${ }^{25}$ IEA, IEA Triennial Report 2000-2003, IEA Press, Santa Monica, CA, USA, 2003.

${ }^{26}$ C. D. Wickens, J. Lee, Y. D. Liu, S. Gordon-Becker, Introduction to Human Factors Engineering, Second Edition, Prentice-Hall, Upper Saddle River, NJ, 2004. 
Дизајнот на интерфејси подразбира ${ }^{27}$ спецификација на природата на интеракцијата човек-машина, односно начинот како човекот е поврзан со машината. Тој опфаќа дизајн на физичките и на когнитивните компоненти на интерфејсот, вклучувајќи дизајн и распоред на контроли и екрани и содржина и прикажување на информации. Физичките компоненти ги опфаќаат факторите како што се: тип на контрола или уред за внес, големина и облик на контролите, позиција на контролите и визуелни и аудиторни спецификации (пр. големина на карактери, контраст на карактери, означување, стапка на сигнализирање, фреквенција на сигнал итн.). Когнитивните компоненти се однесуваат на аспектите на обработка на информациите на интерфејсот (пр. содржината на информациите, распоредот на информациите и сл.). Како што стануваат машините поинтелигентни, сѐ повеќе фокусот на дизајнот на интерфејси се насочува кон когнитивните аспекти на интерфејсот: одредување на оптималното ниво на поддршка од машината, идентификација на типот на информации кои им се потребни на корисниците, одредување како информациите треба да бидат прикажани и идентификација на методологиите за анализа на домените на работа и когнитивните активности. Основната цел е развивање на интерфејси кои најдобро ја поддржуваат човечката изведба на задачите. При примената на сето ова треба да се има предвид природата на задачата, околината и популацијата на корисниците.

Скоро сите Интернет корисници сретнале примери на добар и лош дизајн на веб локации при нивната интеракција со мрежата. Лошиот веб дизајн често доведува до фрустрација на корисниците, бидејќи тие не можат лесно да пристапат до информациите кои ги бараат, а тоа последователно може да доведе до нивно напуштање на веб локацијата. Напуштањето на веб локацијата од страна на корисниците е непосакувано скоро во секој случај, бидејќи ја побива намената на распространувањето на информациите или овозможувањето услуги на Интернет. Организациите кои се успешни во развивањето на добра веб локација и во нејзиното одржување имаат предност пред конкуренцијата. Земајќ го предвид фактот дека од ден на ден сѐ повеќе организации/компании/субјекти се присутни со свои веб локации

\footnotetext{
${ }^{27}$ G. Salvendy, Handbook of Human Factors and Ergonomics, Fourth Edition, John Wiley \& Sons, Inc., Hoboken, NJ, USA, 2012. (p.53)
} 
на Интернет, од исклучително значење е одржувањето и постојаното обновување на информациите на веб локацијата, по нејзиното објавување.

Интернетот, како медиум, овозможува размена на информации и услуги на глобално ниво. Заради потенцијалното влијание кое може да го има врз успехот на една организација или компанија, важно е да се има ефективен дизајн кој ги промовира целите на веб локацијата. Следствено, пред самиот почеток на дизајнот на една веб локација, треба јасно да се дефинира нејзината цел. Со тоа може правилно да се насочи и потпомогне процесот ${ }^{28}$ на одредување кои содржини да се постават на веб локацијата. Но, важно е да се направи разлика помеѓу содржина и естетика. Дизајнот на содржината се фокусира примарно на супстанцата т.е. на информацијата која се содржи на веб локацијата, додека дизајнот на естетиката се фокусира примарно на создавањето на веб локација која е визуелно пријатна за корисниците. Веб локација со добар дизајн може да биде информативна како и убава и креативна на изглед. Меѓутоа, заради тоа што целта на многу веб локации е да овозможат некаков тип на услуга, вообичаено поважно е да се насочи дизајнот повеќе кон содржината отколку естетиката.

Постојат неколку главни компоненти ${ }^{29}$ на една веб локација: нејзината содржина, архитектурата и организацијата, презентацијата на содржината и логиката на програмирањето која се користи за да се интегрира содржината и нејзината презентација во структурата на веб локацијата. При едно истражување ${ }^{30}$ спроведено врз 11 експерти за веб дизајн, кое имало за цел да ги одреди практиките кои ги употребуваат веб дизајнерите при нивните проекти, утврдени се следниве области:

- Информациски дизајн - вклучува идентификација и групирање на содржина за да можат индивидуалните компоненти да бидат интегрирани и организирани во кохерентна целина.

\footnotetext{
${ }^{28}$ H. Liao, Y. Guo, A. Savoy, G. Salvendy, Content Preparation Guidelines for the Web and Information Appliances: Cross-Cultural Comparisons, CRC Press, Boca Raton, FL, 2010.

${ }^{29}$ G. Salvendy, Handbook of Human Factors and Ergonomics, Fourth Edition, John Wiley \& Sons, Inc., Hoboken, NJ, USA, 2012. (p.1324)

${ }^{30}$ M. W. Newman, J. A. Landay, Sitemaps, Storyboards, and Specifications: A Sketch of Web Site Design Practice, Proceedings of the Symposium on Designing Interactive Systems 2000, Association for Computing Machinery
} 
- Навигациски дизајн - вклучува методи за корисниците да се движат низ или да пристапат до различни делови на веб локацијата

- Графички дизајн - вклучува решенија како да се презентираат визуелно индивидуалните делови на информацијата или содржината на корисниците

- Информациска архитектура - вклучува начини како да се комбинираат информациите и компонентите на навигацијата за целата веб локација да функционира како обединет ентитет

- Дизајн на кориснички интерфејс - се однесува на дизајнирањето и оценувањето на употребливоста на веб локацијата, вклучувајќи ги нејзините информациски и навигациски компоненти

Бидејќn веб локацијата е составена од повеќе индивидуални компоненти, дизајнерите треба да ја искористат првично поставената цел на веб локацијата за да одредат кои компоненти се покритични од останатите. Откако дизајнерите ќе ја идентификуваат и одберат содржината која треба да биде поставена, треба да ја структурираат и организираат на начин кој ќе овозможи ефективно презентирање и пронаоѓање на информациите. Важно е дизајнерите да планираат внимателно како да ја структурираат и организираат содржината за да биде спроведена преку веб локацијата до корисниците, затоа што лошиот дизајн на информациската архитектура води до лоша употребливост, правејќи ја веб локацијата потешка за употреба и понепријатна за корисниците. 


\section{1. Уредување}

Студијата ${ }^{31}$ на Jakob Nielsen во однос на тоа колку од посетителите се движат надолу по веб страницата открила дека само $23 \%$ од посетителите се движат при нивната прва посета на дадената веб локација. Тоа значи дека $77 \%$ од посетителите не се движат, тие само ја гледаат содржината над преклопот. Уште позначајно е тоа што процентот на корисници кои се движат надолу по веб страницата се намалува со секоја последователна посета, така што само $16 \%$ се движат при нивната втора посета. Овие податоци посочуваат колку е важно да се постават клучните информации и содржини на видна позиција, особено на почетните страници. Меѓутоа, ова не значи дека треба комплетно да се исполни целиот простор над преклопот, само дека треба најумешно да се искористи за да се спроведат неопходните информации. Преполнувањето со содржини ќе ги направи самите содржини недоволно пристапни кога корисниците се соочени со премногу информации не знаат од каде да започнат. Како и да е со промената на трендовите, однесувањето на корисниците е поподложно на менување. Така, со појавата на веб локации кои се поставени само на една многу долга веб страница, забележана е промена кај корисниците и се повеќе од нив имаат желба (во такви случаи) да ја прегледаат дури и целата страница до долу.

Ефективното прикажување на информациите е критично затоа што му овозможува на корисникот да ја извлече релевантната информација која му е потребна за да ја постигне посакуваната цел. Некои дизајнери го занемаруваат фактот дека иако на нив им е интуитивна организацијата и презентацијата, истото не е случај и кај корисниците. Корисниците по природа се мрзеливи кога станува збор за пребарување одредена информација на било која веб локација. Тие имаат одредени очекувања за тоа каде треба да биде лоцирана дадената информација, главно заради нивното минато искуство со други веб локации. Некој корисник може дури и да се фрустрира кога бараната информација не е лесно пристапна или не се наоѓa каде што тој смета дека треба да биде. Но, доколку се адресираат потребите на корисниците преку соодветна организација и уредување, нивното искуство ќе биде едноставно и задоволително.

\footnotetext{
${ }^{31}$ H. Loranger, J. Nielsen, Prioritizing Web Usability, New Riders Press, Berkeley, CA, 2006.
} 
Документирањето ${ }^{32}$ на движењето на очите од страна на Nielsen и Pernice открило дека информацијата често се чита во „F-обликувана“ форма. Ова однесување ја демонстрирало корисничката тенденција да прочита единствено една линија текст која била лоцирана на врвот на страницата. По таа линија, корисниците само би го прегледале на брзина преостанатиот текст се додека не дојдат до следниот наслов/поднаслов. Преку оваа и други студии, веб дизајнерите и создавачите на самата содржина почнале да се фокусираат повеќе на наслови кои го привлекуваат вниманието и поднаслови во поголемите објави за да можат посилно да го задржат вниманието на читателот. Успешно онлајн искуство се содржи од исполнување на конкретна корисничка информативна потреба брзо и без напрегање.

Мора да се истакне дека веб локација без квалитетна содржина никогаш нема да биде ни квалитетна веб локација. Иако стилизираните дизајни може да делуваат естетски пријатно, тие со тоа може да го одвлекуваат вниманието на корисникот или да ги затскриваат релевантните карактеристики или информациите презентирани на страницата. Корисниците бараат квалитетна информација над сѐ. Уште повеќе, бараат лесно достапна информација. Врвни графички и видео елементи може да го привлечат вниманието на просечниот корисник, но веб локација која нема корисна содржина нема да го задржи неговото внимание многу долго. Меѓутоа, дури и ако се постави содржина која ги исполнува сите потреби на корисникот, распонот ${ }^{33}$ на вниманието на просечниот корисник сепак е ограничен до 15 секунди. Целта во ваков случај за веб дизајнерот е да осигури дека визуелните елементи на веб локацијата функционираат правилно како водилка за погледот на корисникот. Претпоставувајќи дека информацијата напишана или создадена за една веб локација е со висок квалитет, таа веб локација мора да поседува одредени квалитети кои осигуруваат позитивно искуство за корисникот. Најпрво, изборот на бои мора да биде пријатен и да не го одвлекува вниманието на корисникот. Второ, изборот на типографија мора да биде читлив и да го отсликува квалитетот на содржината која се презентира. Последно, уредувањето на веб локацијата мора да биде однапред смислено и да служи како начин за фокусирање на вниманието на корисникот кон онаа информација што

\footnotetext{
32 J. Nielsen, K. Pernice, Eyetracking web usability, New Riders Press, Berkeley, CA, 2010.

${ }^{33}$ S. Weinschenk, 100 Things Every Designer Needs to Know About People, New Riders Press, Berkeley, CA, 2011.
} 
посакува да ја пронајде. Кога ќе се применат правилно овие три области од интерес можат да помогнат да се создаде високо квалитетна веб локација.

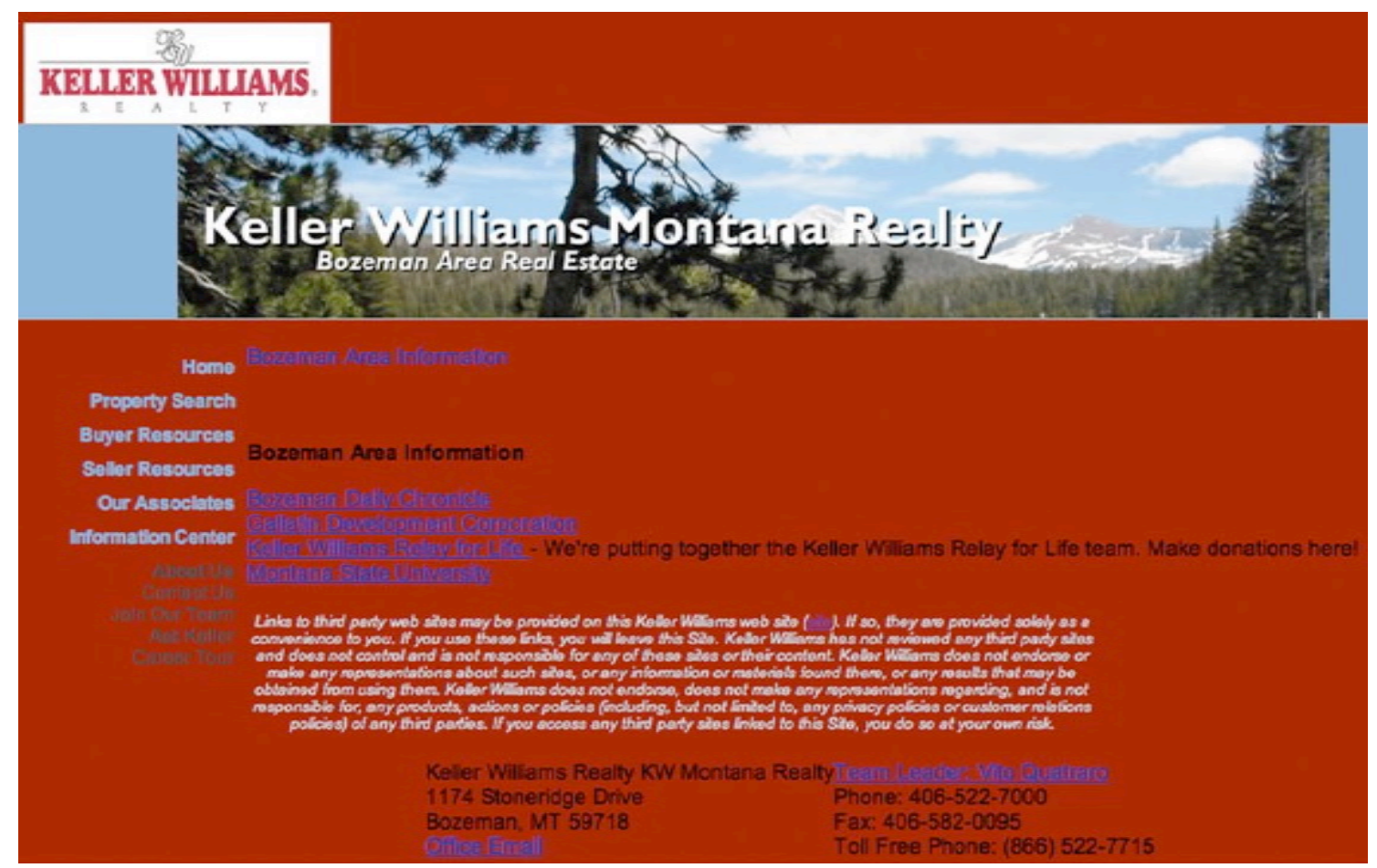

Слика 34 - Пример за веб страница со лош дизајн

Искусните информациски архитекти, уредници на содржини и графички дизајнери можат да бидат многу корисни во процесот на презентирањето на текстот, во однос на едноставно прегледување и читање. Успешното структурирање и организирање на компонентите на веб локацијата последователно води кон поефикасна навигација и пребарување на информациите. 


\section{Word Help Home}

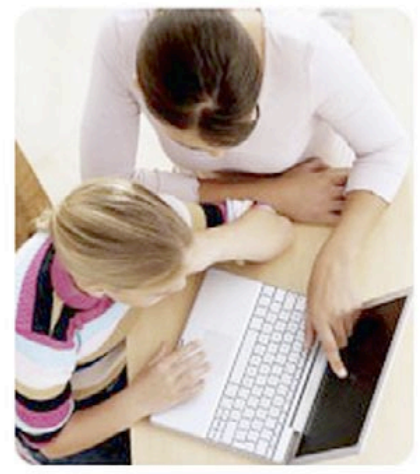

\section{Popular topics}

What's new in Office

Learning roadmap for Word

Change page margins

Set the default font for new documents

Recover text from a damaged document

\section{Ask someone}

Post a question or search for an answer in the user community $G$

Contact Microsoft $\rightarrow$

Слика 35 - Пример за веб апликација со добар дизајн

Исто така, треба да се има предвид дека истата веб локација може да се прикажува малку поразлично кога се пристапува од различен прегледник. Дополнително, со зголемената употреба на паметните мобилни телефони пропорционално се зголемува и пристапувањето до веб локациите од такви и слични уреди, што не било случај порано. Следствено, бидејќи корисниците не се веќе ограничени да пристапуваат на Интернет само од десктоп или лаптоп компјутерите, кога се дизајнира веб локацијата треба да се размислува за нејзино соодветно форматирање/прикажување и на останатите уреди.

Откако структурата на веб локацијата ќе биде утврдена, дизајнерите мора да се фокусираат на системот за навигација кој им овозможува на корисниците да пристапат до содржината од различни области на веб локацијата. Притоа, најмногу внимание треба да се посвети на интуитивноста при употребата на веб локацијата во целост за да се избегне ситуација во која корисникот би се загубил на веб локацијата. Доколку се најде во таква ситуација корисникот има две можности: да започне од почеток или да ја напушти веб локацијата. Контролите на главната навигација мора да се очигледни и со постојана локација на страниците. Не треба да постои страница која нема врски кон претходната (хиерархиски гледано) и би требало да се означуваат посетените врски. 
Потребата од јасна навигација, логична структура и хиерархија која е едноставна за следење може да се искаже преку правилото ${ }^{34}$ на три притискања. Според ова правило корисниците престануваат да ја користат веб локацијата доколку не можат да ја пронајдат или доколку не можат да пристапат до потребната информација или функција во три притискања. Кај некои сложени веб локации можеби ќе има отстапка од овој број на притискања, но во таков случај корисникот мора да знае во секој момент каде се наоѓa на веб локацијата и да има можност од било кое место да се врати назад или доколку може да оди понатаму. Дури и десет притискања може да се во ред доколку корисниците можат да имаат целосно разбирање како функционира системот.

Веб локација која содржи успешно применети принципи на избор на боја, типографија и уредување, преку својата визуелна презентација ќе осигури позитивно интерактивно искуство на корисниците и ќе помогне за зголемување на угледот на дадената веб локација. Затоа се препорачува:

- поставување на важните или критичните информации над преклопот т.е. во просторот кој е видлив за корисникот и без да се движи надолу по страницата

- анализирање и имплементирање на потребите и навиките на корисниците кога започнува нов проект или ревидира некој застарен

- промислено поставување на содржините и употреба графички елементи

- прикажување на содржините на начин кој е поддржан од мнозинството прегледници или овозможување поддршка за застарените верзии на прегледниците кои се сеуште во употреба

- овозможување интуитивна и лесна навигација низ веб локацијата

\footnotetext{
${ }^{34}$ Psychology of web design, Smashing Media GmbH, Freiburg, Germany, 2012. (p.73)
} 


\section{2. Прегледност}

Визуелната бучава во и околу текстот може да го наруши препознавањето на карактерите како и целите зборови. Кај софтверите и веб страниците, визуелната бучава често е резултат на погрешните одлуки на дизајнерите кои поставуваат текст врз позадина со одредена шара (дури и да не е доволно изразена) или прикажуваат текст во одредена боја која дава слаб контраст со позадината.

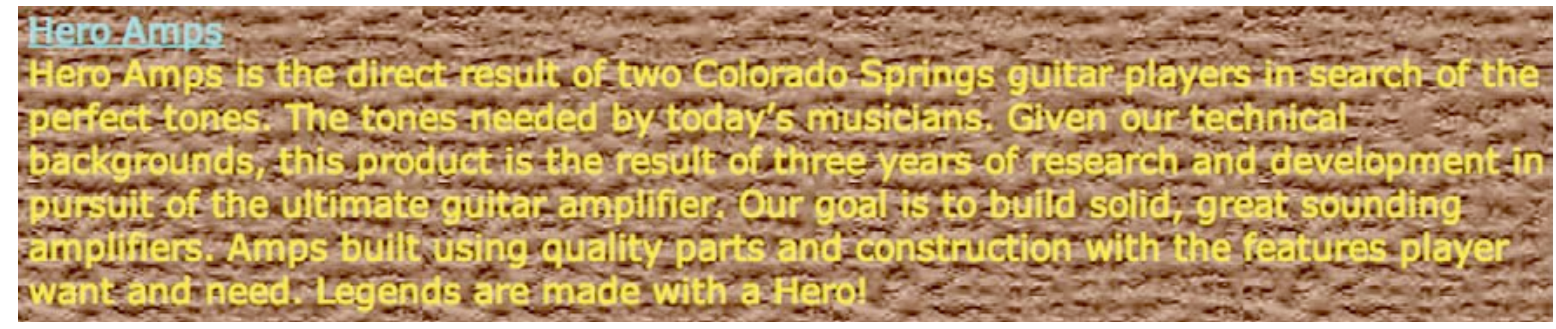

Слика 36 - Пример за визуелна бучава предизвикана од текстура на позадина и боја на текст

Исклучок се ситуациите кога дизајнерите со намера го прават текстот потежок за читање. Највообичаен пример е безбедносната мерка наречена САРTCHA (Completely Automated Public Turing test to tell Computers and Humans Apart) која се превзема на веб страниците за да се идентификува корисникот дека е вистинско човечко суштество, а не Интернет робот.

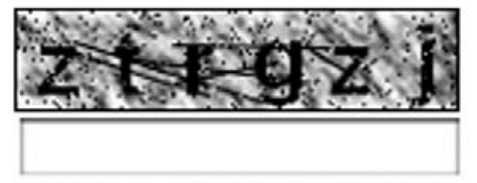

Type the characters you see in the picture above.

Слика 37 - Безбедносна мерка САРТСНА

Визуелната бучава може да се создаде и од самиот текст. Доколку последователните реченици содржат многу повторување, читателите добиваат лоша 
повратна информација за тоа во која линија се фокусирани и дополнително тешко е да се извлечат важните информации.

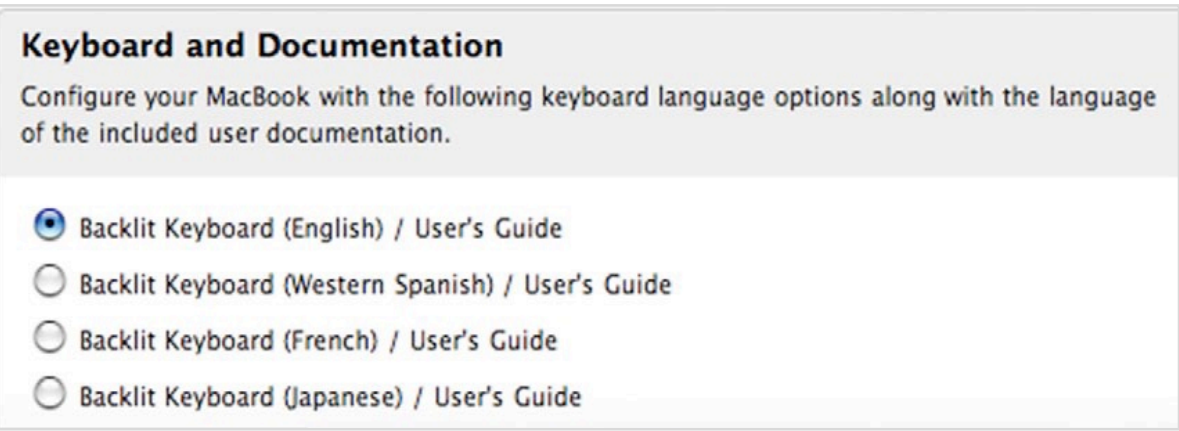

Слика 38 - Пример за визуелна бучава предизвикана од повторување текст

Оставањето празен простор на веб страниците е исто важно, како и исполнувањето на просторот со информации. Празниот простор и дава можност на содржината на веб страницата да „дише“. Тој помага и при создавањето визуелна хиерархија и при групирањето на разни елементи на веб страницата. Но, празниот простор ја прави и целокупната содржина почитлива, а со тоа се подобрува и разбирањето на истата. При едно истражување ${ }^{35}$ се пронашло дека добрата употреба на празниот простор помеѓу параграфите и на левата и десната маргина ја зголемува разбирливоста за скоро $20 \%$. Корисниците сметаат дека е поедноставно да се фокусираат и процесираат нескромно одделени содржини.

Слабата острина на нашиот периферен вид објаснува зошто корисниците на софтвер или веб локации не ги забележуваат пораките за грешка кои се појавуваат. Кога некој притиска на копче или на врска, тогаш сѐ што е надвор од областа на притискањето (вклучувајќи 1-2 cm околу областа, под претпоставка дека екранот се гледа од нормално растојание), претставува периферен вид каде резолуцијата е слаба. Доколку по притискањето се појави порака за грешка во периферијата, не треба да зачудува фактот дека постои можност корисникот да не ја забележи.

\footnotetext{
${ }^{35}$ Psychology of web design, Smashing Media GmbH, Freiburg, Germany, 2012. (p.64)
} 


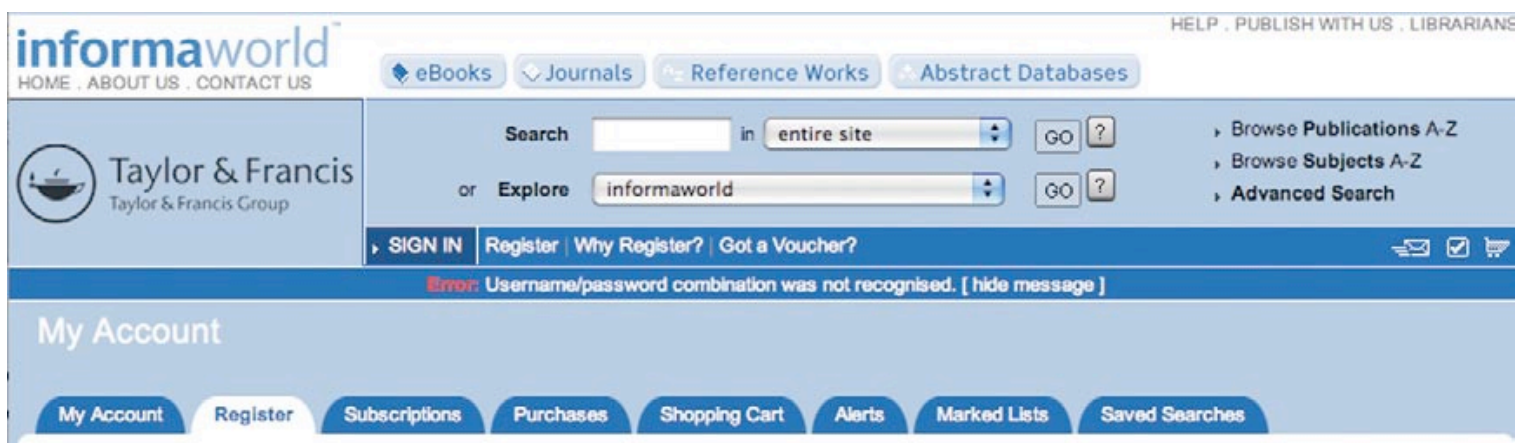

Register

(2) Help

Personal Registration

Creating a personal account will allow you to create marked lists, request email alerts, set up personal subscription access and buy personal subscriptions online.

Institutional Registration

Register your institution to purchase an online subscription for your organisation.

Note that accounts already exist for subscriptions purchased off-line. Ploase contact us for more information.

Already registered? - Please sign in to access an existing account.

Sign in

Username:

Password:

case

sonsitive

Sign In ?

[ forgotten password?] [ Athens users click here to sign in ]?

Слика 39 - Пример за приказ на грешка поставена надвор од фокусот на погледот на корисникот

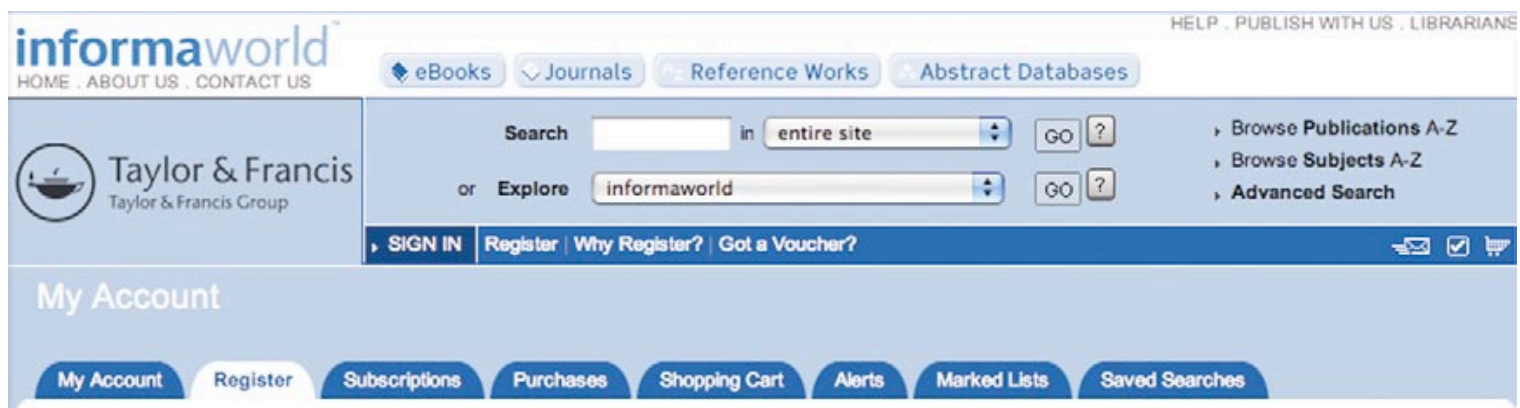

Register

(2) Help

Personal Rogistration

Creating a personal account will allow you to create marked lists, request email alerts, set up personal subscription access and buy personal subscriptions online. Institutional Registration

Register your institution to purchase an online subscription for your organisation.

Note that accounts alroady exist for subscriptions purchased off-ine. Ploase contect us for more information.

Already registered? - Please sign in to access an existing account.

Sign in

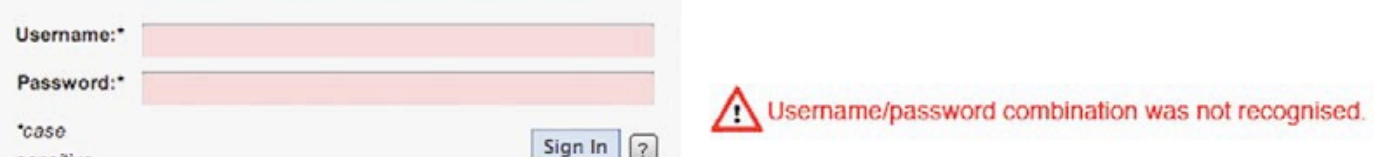

$\begin{array}{lll}\text { coso } & \text { Sign In ? }\end{array}$

Usemame/password combination was not recognised

[ forgotten password?] [ Athens users click here to sign in ]?

Слика 40 - Пример за приказ на грешка во фокусот на погледот на корисникот 
Како пример може да се разгледа низата настани кои се случуваат при најавување на некоја веб локација, но од гледна точка на корисникот. Кога корисникот ги внесува своите информации за најава во полињата „корисничко име“ и „лозинка“ и притиска на копчето „внеси“ погледот му е фокусиран во околината на копчето. Па така, при погрешно внесени информации повторно се појавува истата страница, но со празни полиња и порака за грешка. Во таков случај, доколку пораката за грешка не е позиционирана во околината на копчето „внеси“, постои огромна веројатност корисникот и воопшто да не ја забележи пораката за грешка. Првото нешто што се јавува кај корисникот е сомнежот дека можеби не го притиснал вистинското копче и повторно ги внесува истите информации и повторно го добива истиот приказ на екранот. По ова настанува збунетост кај корисникот која преоѓа во нетрпение, за тоа да поттикне прегледување на целата страница и конечно корисникот да ја забележи лошо поставената порака за грешка. Но, освен на поставеноста, треба да се внимава и на обоеноста на пораката за грешка за да не се случи да се постави во слично обоена околина (околу текст, слики или други елементи).

\section{RETURNING CUSTOMER LOGIN \\ Login ID not found. \\ Login ID: \\ Password:

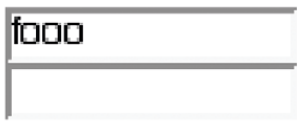 \\ T Remember my Login ID for faster logins. \\ LOGIN}

Слика 41 - Пример за кориснички интерфејс со лошо поставена порака за грешка

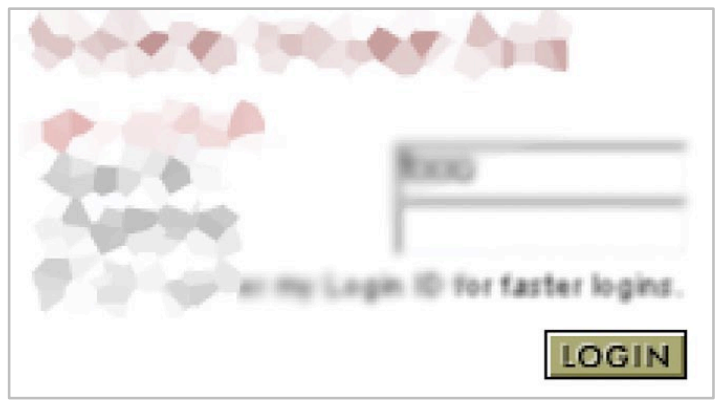

Слика 42 - Илустрација на фокусот на погледот на корисникот 
Постојат неколку вообичаени и добро познати методи ${ }^{36}$ за да се осигури дека пораката за грешка ќе биде видена:

- Поставете ја онаму каде што се фокусирани корисниците со погледот. Луѓето се фокусираат на предвидливи области кога се во интеракција со графички кориснички интерфејси. Во западните општества луѓето имаат тенденција да прегледуваат формулари и контролни панели надолжно од горниот лев агол до долниот десен агол. Додека го придвижуваат покажувачот, луѓето вообичаено гледаат или во неговата моментална позиција или онаму каде го ќе го поместат. Кога луѓе притискаат некое копче или некоја врска, тие може да се претпостави дека ќе гледаат директно таму, барем неколку моменти потоа. Дизајнерите може да ја искористат оваа предвидливост да ги позиционираат пораките за грешка во околината каде се очекува корисниците да гледаат.

- Обележете ја грешката. На некој начин обележете ја видливо пораката за грешка за да посочите јасно дека нешто не е во ред. Често пати ова може да биде извршено со едноставно поставување на пораката за грешка во близина на она на коешто се однесува, се разбира доколку тоа не е многу далеку од местото каде корисниците се очекува да гледаат.

- Користете симбол за грешка. Направете ги грешките или пораките за грешка повидливи со нивно обележување со помош на симбол за грешка, како на пример: $\mathbf{X}, \AA$

- Резервирајте ја црвената боја за грешки. Според конвенција, кај интерактивните компјутерски системи црвената боја се користи во конотација на алармирање, опасност, проблем, грешка и сл. Користејќи ја црвената боја за било која друга информација на компјутерски екран се потпомага недоразбирањето. Исклучоци од оваа насока може да се разгледуваат само во случаи кога субјектот има веќе воспоставен идентитет во кој е употребена црвената боја и во тие случаи може да се употреби друга боја за пораката за грешка и да се дополни со симбол.

\footnotetext{
${ }^{36}$ J. Johnson, Designing with the mind in mind, Morgan Kaufmann Publishers, Burlington, MA, USA, 2010. (p.72)
} 
Добра примена на претходно споменатите насоки може да се забележи во следниот пример - формулар за основање профил за е-пошта на компанијата AOL. Полињата за внесување податоци каде има грешка се обележани со црвени симболи за грешка. Пораките за грешка се прикажани во црвена боја и се во близина на грешката. Дополнително, најголемиот број пораки за грешка се појавуваат веднаш штом се внесе некој податок со одредена грешка, додека корисникот е сеуште фокусиран на тој дел од формуларот, наместо тоа да биде сторено откога корисникот ќе го поднесе формуларот.

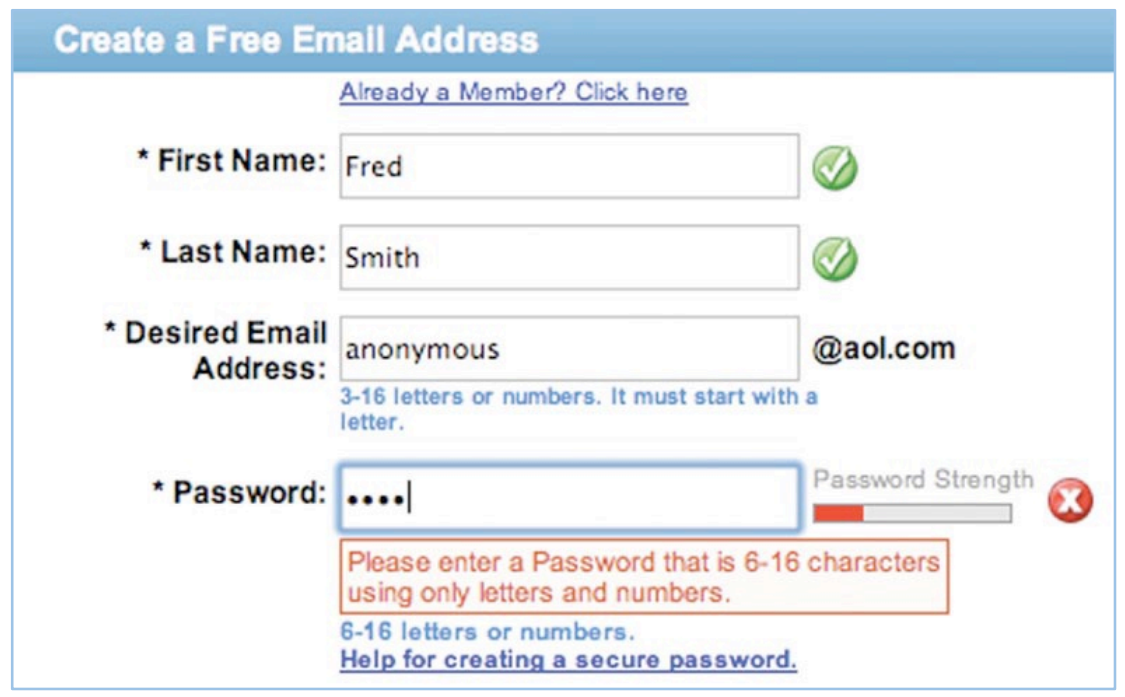

Слика 43 - Пример за формулар со добро поставени повратни информации

Доколку вообичаените, конвенционални методи наменети корисниците да ги забележат пораките за грешка не се доволни, постојат три повлијателни методи ${ }^{37}$ кои им се на располагање на дизајнерите на интерфејси. Меѓутоа, иако овие методи се доста ефективни, имаат и значајни негативни ефекти така што треба да се користат повремено и со доста внимание.

Првиот метод е прикажување на порака за грешка во дијалог прозорец, на овој начин се прекинува дејството на корисникот и се изнудува непосредно посветување внимание. Ова е во ред доколку пораката за грешка сигнализира критична состојба, но

\footnotetext{
37 J. Johnson, Designing with the mind in mind, Morgan Kaufmann Publishers, Burlington, MA, USA, 2010. (p.74-76)
} 
може да ги изнервира корисниците доколку се работи за одредена незначајна порака (пр. потврдување на извршувањето на одредена акција која е побарана од самиот корисник). Кога станува збор за веб локации, некогаш подобро е да се избегнуваат дијалог прозорци затоа што некои корисници во поставките на своите прегледници оневозможуваат прикажување на дијалог прозорци. Па така, доколку прикажувањето на пораките за грешка на одредена веб локација зависи само од дијалог прозорци, некои нејзини корисници може воопшто да не ги видат.

Вториот метод е употреба на звук при прикажувањето на пораката за грешка, бидејќn со тоа се поттикнува корисникот да го прегледа екранот за да ја пронајде грешката. Овој метод е особено корисен кога пораката за грешка се прикажува некаде каде не гледа корисникот во дадениот момент. Кај овој метод недостатокот е тоа што корисникот на компјутерот може комплетно да го исклучи звукот или да го намали доволно за да не може да го слушне. Затоа сигнализирањето грешки исклучиво со помош на звуци може да биде решение во одредени контролирани услови.

Третиот метод е поврзан со периферниот вид. Имено, периферниот вид можеби во одредени ситуации не ограничува, но одлично забележува движење, а тоа последователно предизвикува насочување на погледот кон движењето и фокусирање во таа област. Дизајнерите на кориснички интерфејси можат да го искористат ова кај пораките за грешки со тоа што ќе ги придвижат за кратко или ќе ги обележат со одредено осветлување на полето каде се наоѓаат. Меѓутоа, движењето или означувањето треба да биде кратко, не само затоа што не е потребно многу за човековиот систем за вид, туку и заради тоа што некои корисници се навикнати да ги игнорираат постојаните движења заради рекламите кои се поставуваат на веб страниците. 


\section{3. Бoja}

Бојата зазема централно место во нашите животи. Луѓето гледаат и реагираат на различни бои и нијанси илјадници пати во текот на денот. Тие се и зависни од боите за да испратат одредена порака за повеќе различни работи. Исто како што мислиме дека е важно одбирањето на соодветна боја и дизајн на облека за одреден настан од значење, така и во веб дизајнот е важно одбирањето на соодветни шеми на бои за да се пренесе посакуваната порака и да се претстави вистински имиџот на компанијата.

Веб страницата е една од најефективните алатки за да се комуницира со многу од луѓето низ целиот свет. Но, една веб страница не испраќа само одредена содржина, туку и слики, импресии и емоции низ виртуелен простор. Интерпретацијата на текстот и реакцијата на пораката е под големо влијание од контекстот како сѐ е презентирано. Еден од најважните елементи на тој контекст е бојата. Бојата има и емотивни и психолошки влијанија. Бојата може да го привлече нашето внимание и да не натера да реагираме на одреден начин врз основа на нашите лични искуства и убедувања. За да се испрати ефективно одредена порака на Интернет правилниот избор на шема на бои е од големо значење. Кога се посакува да се испрати силна порака до корисниците, би се избрала топла шема на бои, а пак кога се посакува да се утеши или смири публиката би се искористила ладна шема на бои. Аналогните и монохроматските бои оддаваат чувство на хармонија, додека комплементарните бои овозможуваат висок контраст. Во секој случај, употребата на бои мора да се прошири надвор од опсегот на единствено преден план и позадина. Дизајнерот треба да има добро познавање на боите и не треба да ја жртвува читливоста на една веб страница.

Дизајнерите треба секогаш да имаат предвид дека немаат целосна контрола околу тоа какво ќе биде гледачкото искуство на корисниците. Различни прегледници може да ги рендерираат боите различно, заради ова кога се работи со бои треба да се употребуваат „browser-safe“. Но и во таков случај не е до крај гарантирано прикажувањето на ист начин помеѓу различни оперативни системи или различни монитори, затоа потребно е опширно испитување. Боите кои наликуваат како јасни за разликување во развивачката установа на екраните на компјутерите на развивачкиот 
тим и во услови на нормална осветленост на канцеларијата, може да не бидат лесни за разликување во некои околини каде се користи софтверот.

Човековата перцепција за бои има и предности и ограничувања. Многу од тие предности и ограничувања ${ }^{38}$ се релевантни за дизајнот на кориснички интерфејси, како на пример:

- Нашиот вид е оптимизиран да забележува контрасти, а не (апсолутно) ниво на осветленост

- Нашата можност да разликуваме бои зависи од тоа како боите се прикажани

- Некои луѓе не можат да распознаваат бои

- Екранот на корисникот и условите на гледање може да влијаат врз перцепцијата на бои

Одредени комбинации на бои како на пример црвена боја на текст на сина позадина можат да создадат ефект ${ }^{39}$ познат како chromostereopsis. Овој ефект предизвикува замор на очите на корисникот, бидејќи една од боите се перципира во преден план додека останатите изгледаат како да се загасени. Црвената и сината боја го предизвикуваат најјакиот случај на chromostereopsis, но други комбинации на бои како на пример црвена и зелена или пак зелена и црна може да предизвикаат слични резултати.

Кај интерактивни софтверски системи кои зависат од бојата за да се пренесе одредена информација, следете ги следниве насоки ${ }^{40}$ за да осигурите дека корисниците на софтверот ја добиваат вистинската информација:

- Направете разлика помеѓу боите преку интензитетот на бојата и осветленоста, како и преку брановата должина. Бидете сигурни дека контрастот помеѓу боите е јак, но не доближувајте премногу спротивставени бои. Еден од начините како може да се тестира дали боите се доволно различни една од друга е да се видат во монохроматска верзија преку

\footnotetext{
38 J. Johnson, Designing with the mind in mind, Morgan Kaufmann Publishers, Burlington, MA, USA, 2010. (p.53)

${ }^{39}$ S. Weinschenk, 100 Things Every Designer Needs to Know About People, New Riders Press, Berkeley, CA, USA, 2011.

40 J. Johnson, Designing with the mind in mind, Morgan Kaufmann Publishers, Burlington, MA, USA, 2010. (p.61-62)
} 
нијанси на сиво. Ако не можете да ги разликувате боите кога се прикажани сиви, тие не се доволно различни.

- Користете карактеристични бои. Боите кои луѓето можат најлесно да ги разликуваат се оние кои предизвикуваат јак сигнал (позитивен или негативен) на еден од трите канали (црвена-зелена, жолта-сина и црнабела) за перцепција на боја, а неутрален на останатите два канала. Тие бои се: црвената, зелената, жолтата, сината, црната и белата. Сите други бои предизвикуваат сигнали на повеќе канали за боја и заради тоа нашиот систем за вид не може да ги разликува нив од другите бои толку брзо и толку лесно како што може да ги разликува како шесте претходно наведени бои.
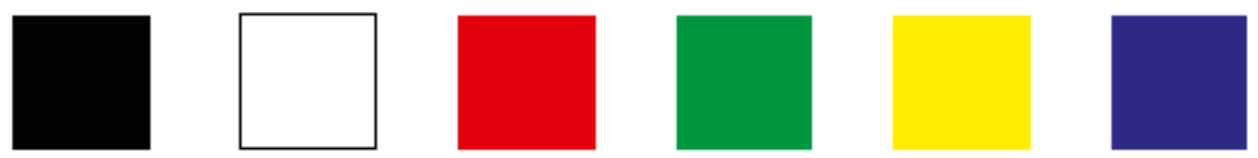

Слика 44 - Карактеристични бои

- Избегнувајте парови бои кои луѓето кои не распознаваат бои нема да може да ги разликуваат. Такви парови вклучуваат: темно црвена наспроти црна, темно црвена наспроти темно зелена, сина наспроти виолетова, светло сина наспроти бела. Не користете темно црвени, темно сини или темно виолетови нијанси наспроти било кои темни бои. Наместо тоа користете темно црвени, темно сини или темно виолетови нијанси наспроти светло жолти или светло зелени нијанси на бои.

- Користете боја дури и излишно со употреба на некои други елементи. Не се ослонувајте само на бојата. Доколку користите боја за да обележите нешто, обележете го и на друг начин исто така. На пример софтверот iPhoto на компанијата Apple користи боја и симбол за да се создаде разлика помеѓу автоматски генерираните фото албуми и корисничките фото албуми. 


\section{Слика 45 - Употреба на боја за разликување на икони од ист тип}

- Одвојте ги премногу спротивставените бои. Поставувањето на премногу спротивставени бои една до друга или една врз друга предизвикува вознемирувачка треперлива сензација и треба да се избегнува.

\section{THIS!}

Слика 46 - Пример за употреба на спротивставени бои 


\section{4. Типографија}

Изборот и големината на фонтот кој ќе се користи за да се прикажат информациите може да му обезбеди на корисникот перцепција ${ }^{41}$ за значењето на дадената веб локација дури и пред да почне со читање. Класични серифни фонтови како Times New Roman или Garamond им обезбедуваат на читателите да читаат без замор. Помодерните сансерифни фонтови како Helvetica или Arial се исто така комфорни, но му овозможуваат помодерно чувство на текстот. Пораката која ја пренесува веб локацијата може да се наруши, кога веб дизајнерот почнува неумешно да експериментира со фонтови. Курзивни фонтови не служат добро кај главен текст, бидејќn линиите на секоја буква често се фини и тешки за читање кога се премали. Иако се лесни за читање, разиграните фонтови како Comic Sans треба да се внесуваат исклучиво на лични веб локации или веб локации со намена соодветна на нивниот изглед, бидејќи овие фонтови не се почитуваат во бизнис и професионалната дизајнерска заедница. Големината на фонтот кој се користи на одредена веб локација исто така игра значајна улога во читливоста и перцепцијата на презентираната содржина. Текст кој е премногу мал може да биде тежок за читање и текст кој е премногу голем може да го одвлекува вниманието на корисникот и да одземе вреден простор на дадената веб страница. Идеалната големина на фонт варира помеѓу специфичниот фонт кој бил одбран и наменетата цел на текстот кој се прикажува. Имено, главен текст со Times New Roman може да изгледа најдобро со големина помеѓy 10 и 12, додека наслов со задебелена Helvetica може да има посилен впечаток со големина од 12 или 14. Треба да се истакне дека ширината на карактерите и растојанието помеѓу нив се разликува помеѓу фонтовите и тоа исто така треба да се има предвид кога се одлучува кој фонт да се вметне во веб локацијата.

Читањето може да биде нарушено (дури и во случаи кога се употребува познат вокабулар) од фонтови кои се тешки за читање. Исто така и употребата на одредени карактеристики на фонтот (пр. текст испишан само со големи букви) може да го отежни читањето.

\footnotetext{
${ }^{41}$ S. Weinschenk, 100 Things Every Designer Needs to Know About People, New Riders Press, Berkeley, CA, USA, 2011.
} 


\section{ABRAMAR}

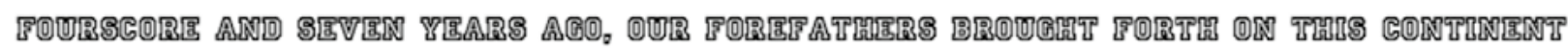

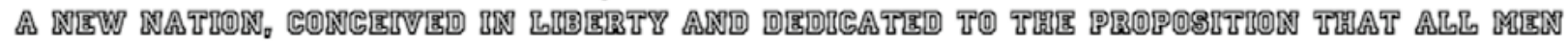

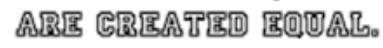

NOW WE ABE ENDGA

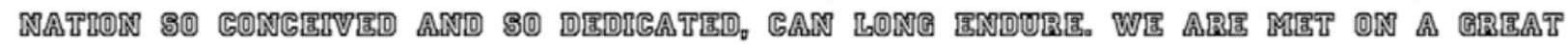

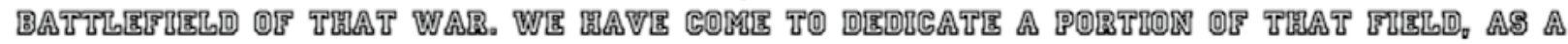

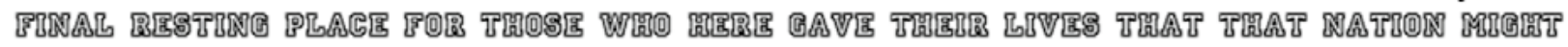

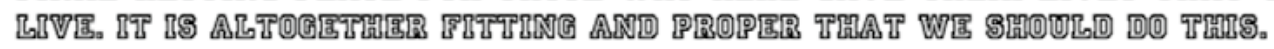

BDיף,

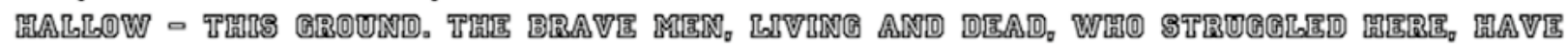

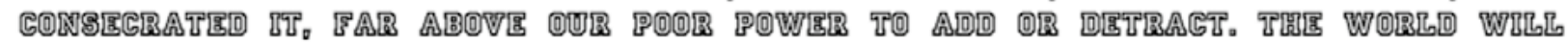

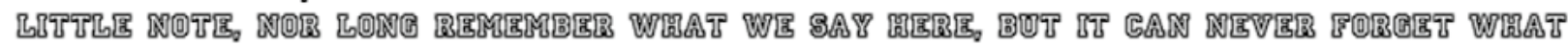
पᄑI

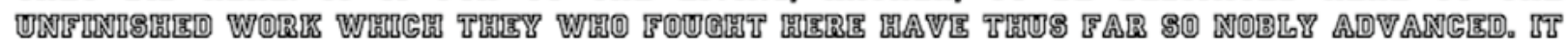

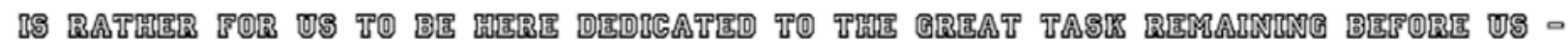
TIA FEOM TIE

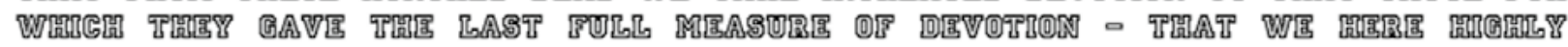

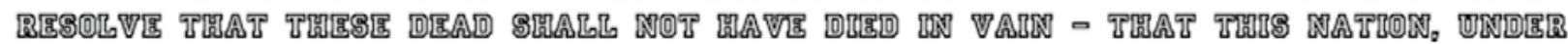

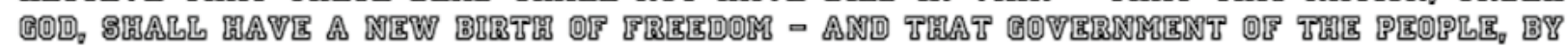

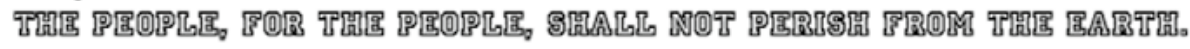

\section{Слика 47 - Пример за текст со лоши карактеристики на фонт}

Од едно истражување ${ }^{42}$ спроведено од Smashing Magazine, кое имало за цел да ги открие најдобрите практики кои се однесуваат на карактеристиките на типографијата на веб страниците, добиени се следните резултати:

- Висината на линијата (изразена во пиксели) $\div$ основната големина на фонт (изразена во пиксели) $=1,48$

- Должината на линијата (изразена во пиксели) $\div$ висината на линијата (изразена во пиксели) $=27,8$

- Просторот помеѓу параграфите (изразен во пиксели) $\div$ висината на линијата (изразена во пиксели) $=0,754$

- Оптималниот број на карактери по линија е 55 до 75

\footnotetext{
${ }^{42} \mathrm{http} / / /$ www.smashingmagazine.com/2009/08/20/typographic-design-survey-best-practices-from-the-bestblogs/
} 


\section{5. Употребливост}

Екранот на мобилните уреди, без разлика дали станува збор за мобилен телефон или таблет, ги прикажува веб локациите различно од екранот на десктоп или лаптоп компјутерите. Исто така и навигацијата низ локацијата се извршува со прсти (исклучок во овој случај се екраните на компјутерите кои се осетливи на допир) што е драстично различно искуство во споредба со прецизната навигација со компјутерско глувче. Сето ова укажува дека веб локацијата треба да биде дизајнирана онака како би овозможила пријатно корисничко искуство за сите луѓе кои ја посетуваат - десктоп, лаптоп, таблет или корисници на мобилни телефони.

Луѓето кои користат кориснички интерфејси основани на допир се во интеракција со системот преку нивните прсти. Затоа контролите на корисничките интерфејси мора да бидат доволно големи за да ги опфатат акциите на врвовите на прстите, без да ги фрустрираат корисниците со погрешни и несакани акции.

Во насоките ${ }^{43}$ за кориснички интерфејси за првите верзии на iPhone, компанијата Apple препорачувала минимум големина на елементите кои треба да се притиснат од 44px висина и 44px ширина. Меѓутоа, заради тоа што физичката големина на пикселите може да варира во зависност од густината на екранот, овие спецификации одговарале за уредите со резолуција од 320x480px и 3.5in екран со густина од 164pрі. Со појавата на iPhone 4 и на ретина екранот, 3.5in екран имал густина од 326ррі (следствено и поголема резолуција - 640x960px). За да ги усогласи спецификациите, компанијата ги обновила спецификациите и ги променила единиците мерки од пиксели во точки.

Во упатството 44 за кориснички интерфејси и интеракции за Windows Phone, компанијата Microsoft предлага големина на површина за допир од 9mm/34px или минимална големина од $7 \mathrm{~mm} / 26 \mathrm{px}$ со минимално растојание помеѓу елементи од $2 \mathrm{~mm} / 8 \mathrm{px}$ и визуелната големина на контролно копче да биде 60-100\% од големината на површината за допир. Но, од компанијата дозволуваат големината на површината за допир да биде поголема од 9mm доколку:

\footnotetext{
${ }^{43} \mathrm{http}: / /$ www.lukew.com/ff/entry.asp?1085

${ }^{44} \mathrm{http}: / /$ www.lukew.com/ff/entry.asp?1085
} 
- елементот многу често се користи (притиска)

- резултатот од погрешно притискање е сериозно непосакуван или навистина фрустрира

- елементот е лоциран кон работ на екранот или е тежок за погодување

- кога елементот е дел од секвенцијална задача (пр. употреба на броеви за бирање)

Pесурсите $^{45}$ за развивачите на Nokia предлагаат дека допирливите елементи на интерфејсот не треба да се помали од најмалата просечна големина на подлогата на прстот. Односно, не помала од $1 \mathrm{~cm}$ во дијаметар или $1 \times 1 \mathrm{~cm}$ квадрат. Минималните големини за елементи кои треба да се користат со прсти се:

- $7 x 7 \mathrm{~mm}$ co $1 \mathrm{~mm}$ јаз за употреба со показалец

- 8 x8mm co $2 \mathrm{~mm}$ јаз за употреба со палец

- Компоненти од листа треба да имаат минимум 2mm проред

Но, ширината на прстот ја ограничува густината на елементи на екранот. Доколку елементите се поставени премногу блиску едни до други, корисникот нема да може да одбере ниеден.

\footnotetext{
${ }^{45}$ http://www.lukew.com/ff/entry.asp?1085
} 

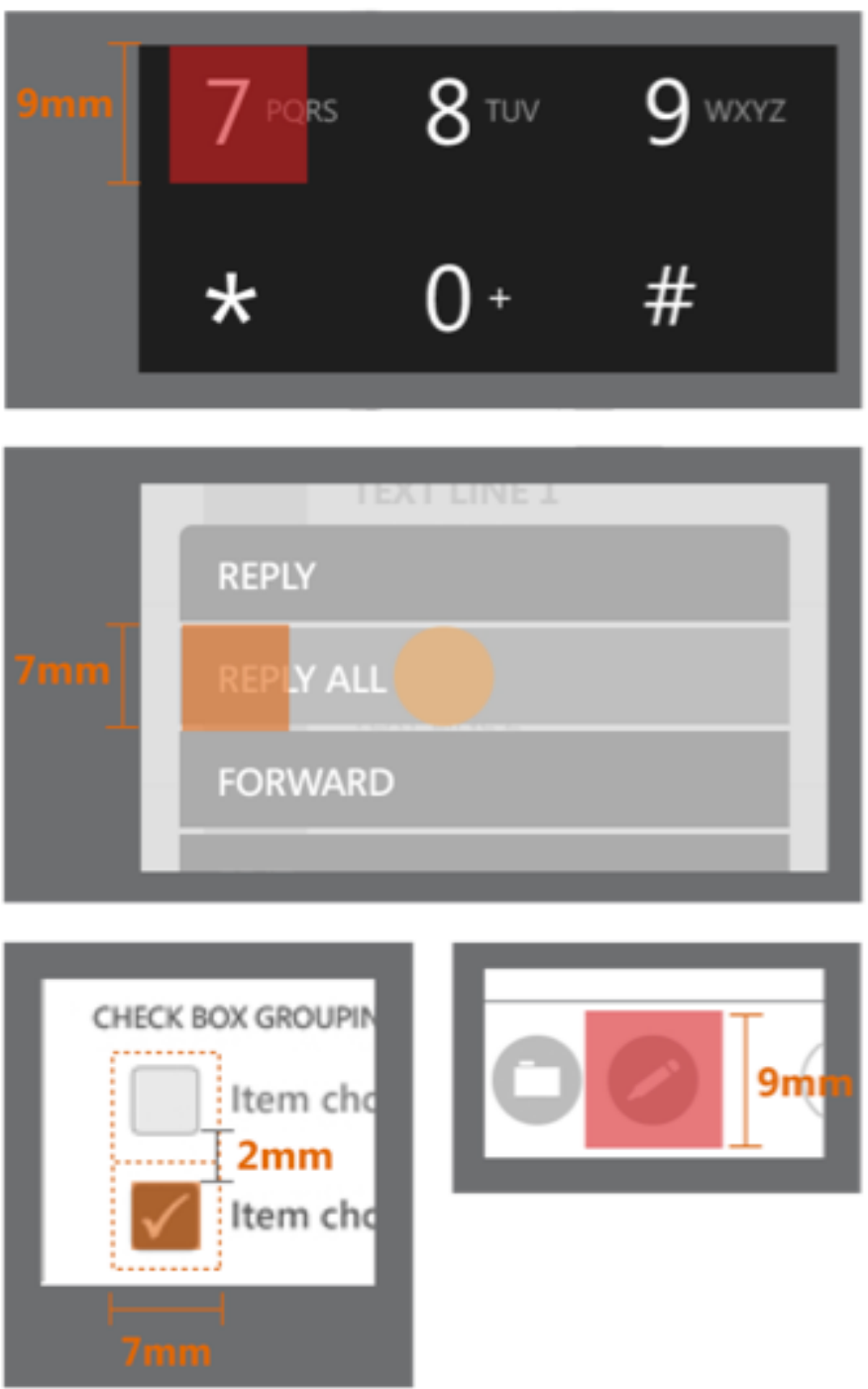

Слика 48 - Илустрација на димензионирање на копчиња за интеракција со допир 


\section{5. Истражувања и анализи}

Интернетот ја дава можноста на веб локацијата да биде пристапено од секаде и во секое време и преку најразлични уреди. Како резултат на ова, во почетните фази или истражувачките фази на веб дизајнот, потребно е да се осознаат моменталните статистички податоци за употребата на Интернетот и да се добијат информации за целната група корисници.

За таа цел во продолжение најпрво ќе бидат анализирани статистички податоци превземени од истражувања спроведени од одбрани организации ширум светот и од Државниот завод за статистика на Република Македонија.

Потоа, ќе бидат изнесени заклучоците од спроведените истражувања на корисниците. Овие истражувањата главно се извршени преку анкетирање, со помош на онлајн платформата Kwiksurveys. На овој начин преку повеќе затворени прашања се добиени информации за корисниците и нивните преференции. Дополнително, предноста од употребата на овој пристап е добивањето информации за пократок временски рок од поголем број на испитаници, а заради дигиталните записи и типот на прашањата добиените резултати побрзо се процесираат.

Понатаму ќе бидат анализирани актуелните светски трендови во веб дизајнот, за да се одреди кој е моментално најпопуларен стил и дали истиот може да се вклопи (или како би требало да се прилагоди) во темата на задачата.

На крај ќе бидат анализирани неколку можни конкурентски веб локации. За да се согледаат предностите и недостатоците во нивниот дизајн. Од сето ова се очекува да се добие одговор на некои клучни прашања, за конечно да се одреди текот на извршувањето на задачата и вистинските аспекти од интерес. 


\section{1. Анализа на статистички податоци од одбрани организации ширум светот}

Светските статистики ${ }^{46}$ покажуваат дека во последниот квартал на минатата година најмногу Интернет корисници имало во Азија (45,6\%). Следни по бројност се европјаните со 18,9\% од вкупниот број Интернет корисници. Додека Латинска Америка, Северна Америка, па дури и Африка меѓу себе имаат многу мали разлики по бројноста и може да се каже дека го делат третото место со околу $10 \%$. Помалку Интернет корисници има на Средниот Исток (3,7\%), а најмалку во Океанија/Австралија односно 0,9\% од вкупниот број Интернет корисници.

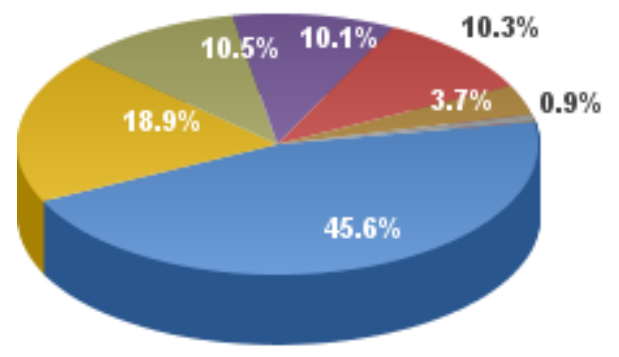

Asia $45.6 \%$

Europe $18.9 \%$

Lat Am / Carib. 10.5\%

North America 10.1\%

Africa $10.3 \%$

Middle East $3.7 \%$

Oceania / Australia $\mathbf{0 . 9} \%$

Графикон 2 - Приказ на статистички податоци за Интернет корисници од Internet World Stats

\footnotetext{
${ }^{46}$ http://www.internetworldstats.com/stats.htm
} 


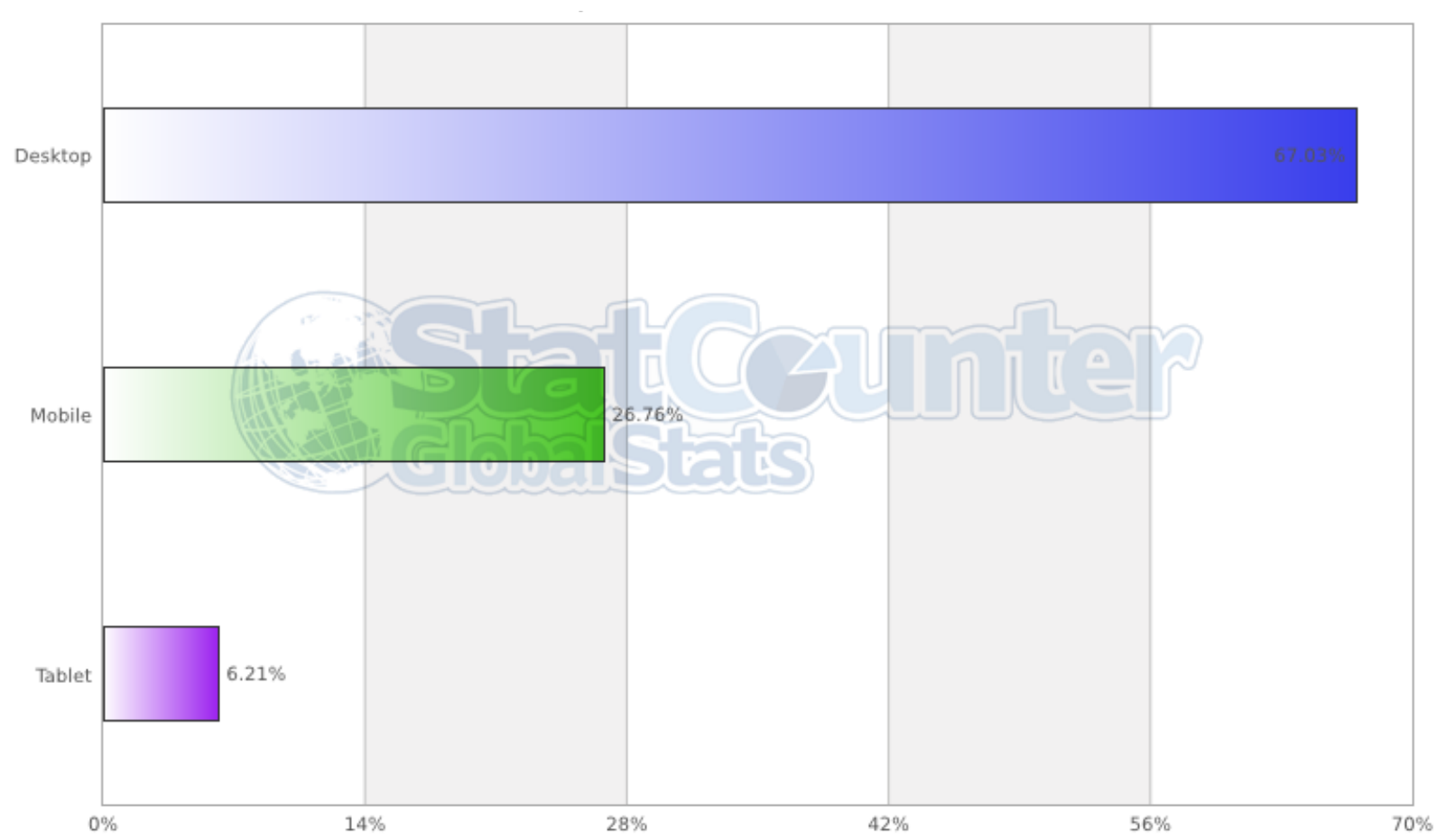

Графикон 3 - Приказ на статистички податочи за употреба на платформи за пристап до Интернет од Global Stats

Кога станува збор за платформите кои се користат за пристап до Интернет, најмногу ${ }^{47}$ од Интернет корисниците во светот ја употребуваат десктоп платформата, односно 67,03\% од вкупниот број Интернет корисници. 26,76\% пристапуваат со своите мобилни телефони на Интернет, а најмалку $(6,21 \%)$ пристапуваат од таблети. Иако во моментов можеби не заземаат голем дел мобилните платформи, може слободно да се каже дека нивната употреба во последно време е во постојан пораст, така што разумен и мудар чекор при создавањето веб локација е примената на прилагодлив дизајн за да може да се опслужат сите уреди истовремено, а и новите уреди (со различни резолуции на екрани) кои допрва ќе се појават на пазарот.

\footnotetext{
${ }^{47}$ http://gs.statcounter.com/
} 


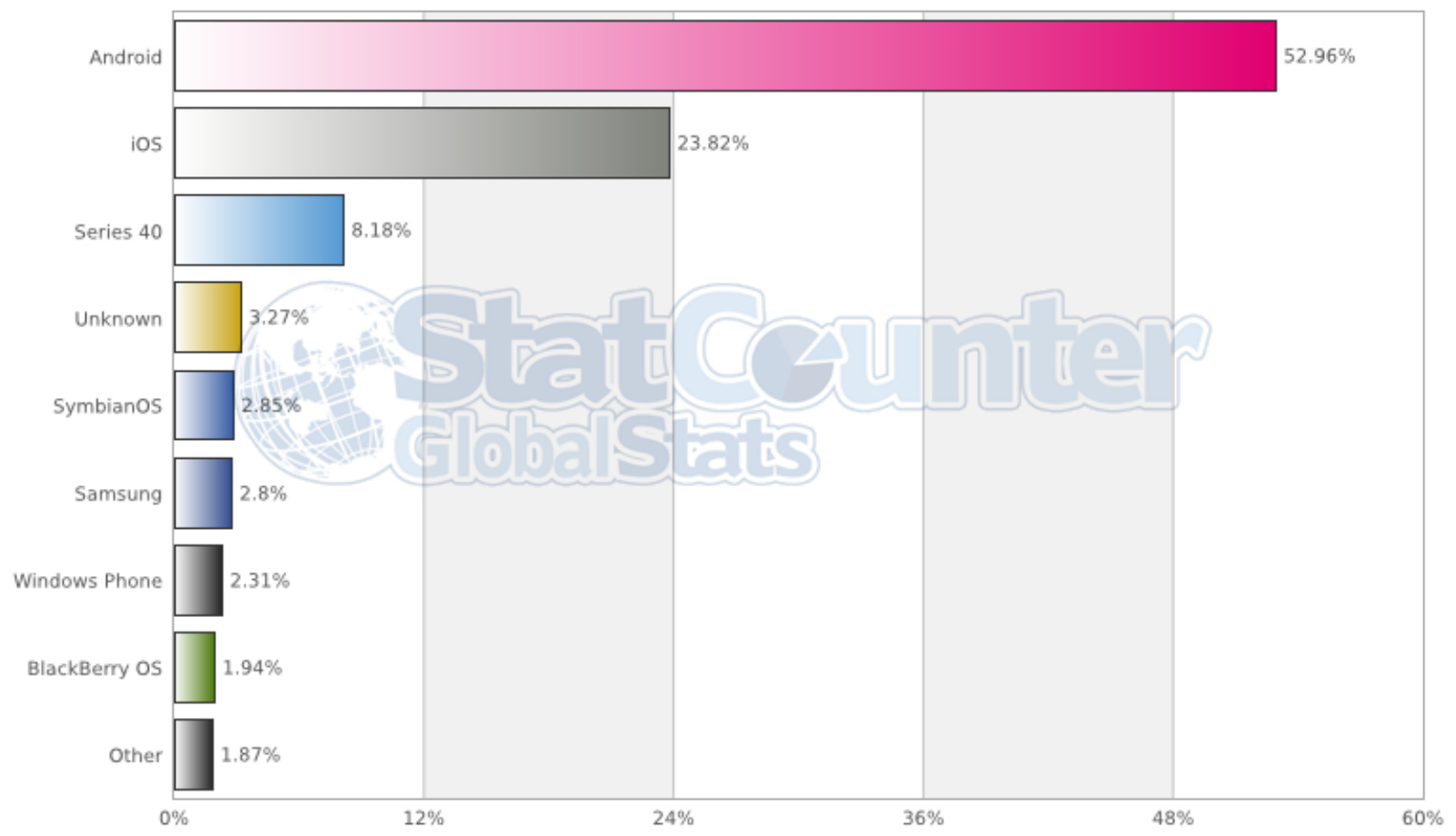

Графикон 4 - Приказ на статистички податоци за употреба на оперативни системи кај мобилни телефони од Global Stats

Бидејќи секогаш постои и можноста за развивање на посебна апликација за мобилните уреди (покрај развивањето на веб локација соодветна само за персоналните компјутери) треба да се разгледа кој оперативен систем се употребува најмногу. Доминантен оперативен систем кај мобилните телефони е Android оперативниот систем на компанијата Google, следен од iOS оперативниот систем за Apple уредите, а останатите оперативни системи заземаат значајно помал дел. 


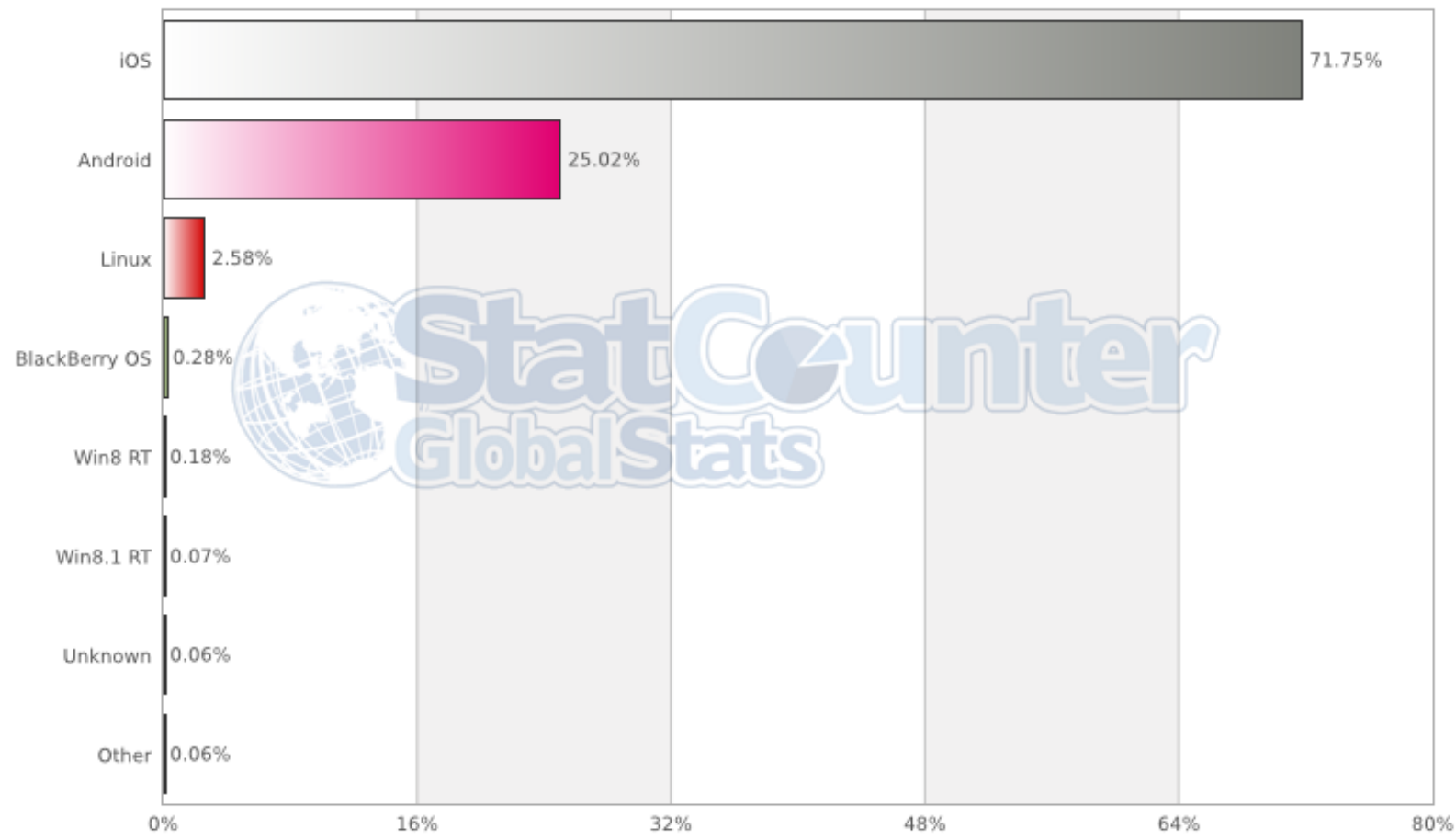

\section{Графикон 5 - Приказ на статистички податоци за употреба на оперативни системи кај таблети} od Global Stats

Ситуацијата кај табелетите е спротивна. Убедливо водство има IOS оперативниот систем, многу помал удел има оперативниот систем Android, а останатите се скоро и незначајни. Ова укажува дека би требало да се развиваат повеќе апликации, бидејќи различни оперативни системи се употребуваат, но покрај тоа може да биде потребно и да се развиваат и одделни апликации за мобилните и таблетите заради различната резолуција на уредите, различниот интерфејс, различното корисничко искуство. Според тоа, доколку не се искористува некоја специфична карактеристика на оперативните системи, изработката на мобилна апликација наместо веб локација со прилагодлив дизајн не е баш исплатлив чекор. 


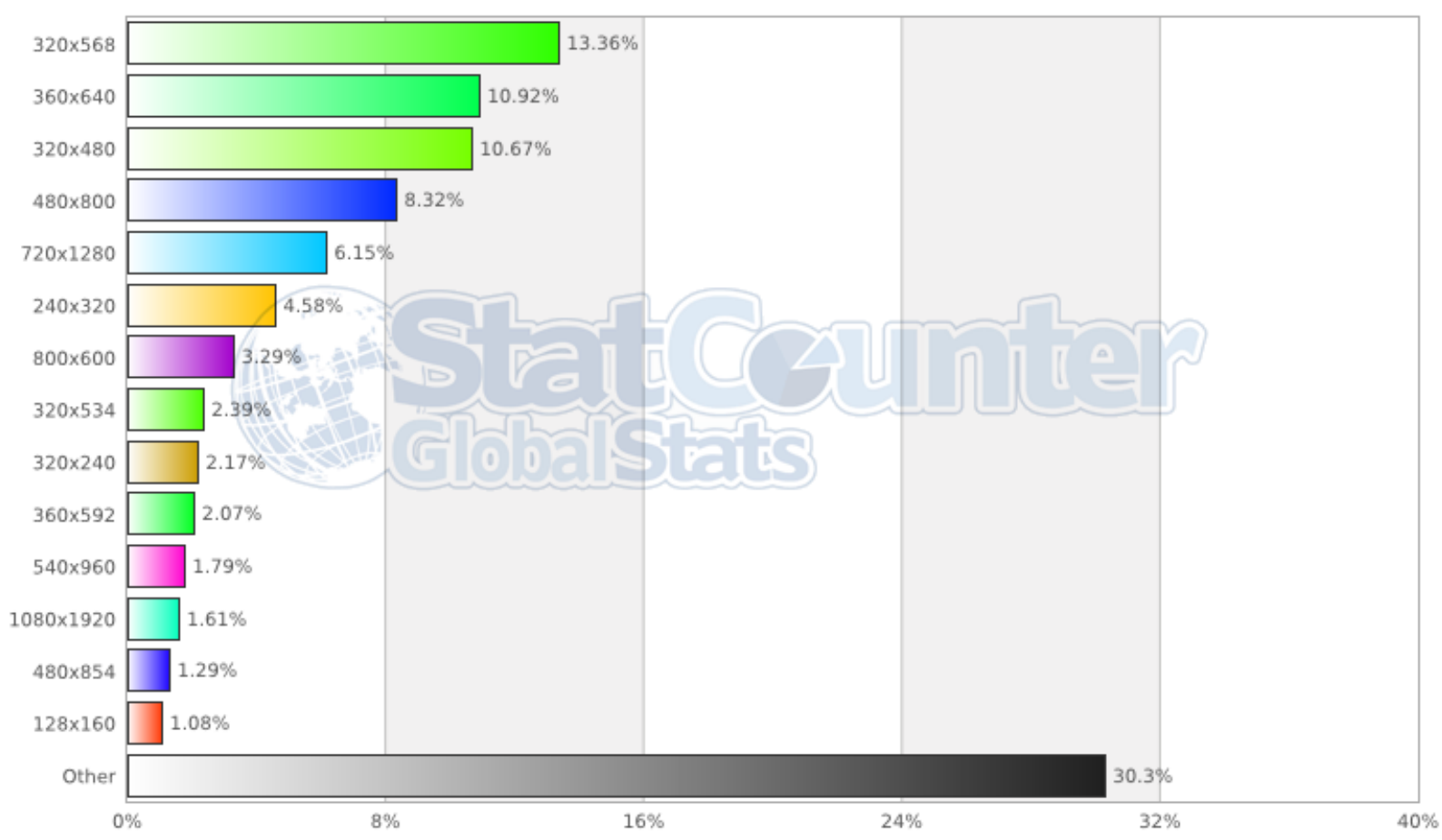

Графикон 6 - Приказ на статистички податоци за употреба на резолуции од Global Stats

Дополнително, со појавата на екрани со различна густина на пиксели на екраните и следствено со многуте различни резолуции само кај мобилните телефони, употребата на прилагодлив дизајн е дефинитивно оправдана. Од прикажаниот график може да се забележи дека преовладуваат уредите со мали екрани и релативно блиски мали резолуции. Следствено, доколку кај тие резолуции нема проблеми при интеракцијата (пр. копчињата и врските се доволно големи и соодветно оддалечени едни од други) кај останатите уреди бидејќи има повеќе простор нема да има никакви недостатоци. 


\section{2. Анализа на статистички податоци од Државниот завод за статистика на РМ}

Заради тоа што се очекува примарната група корисници на веб локацијата да биде од Република Македонија, од големо значење се и податоците од Државниот завод за статистика. Конкретно, податоците за користењето на информатичко - комуникациски технологии во домаќинствата и кај поединците, но и во деловните субјекти.

Според податоците ${ }^{48}$ на Државниот завод за статистика, во првото тримесечје од 2014 година, 68.3\% од домаќинствата имале пристап на интернет од дома. Тоа е за 3.3\% повеќе во споредба со истиот период од 2013 година. Речиси сите (99.1\%) домаќинства со Интернет пристап, имале широкопојасно (фиксно или мобилно) поврзување на интернет.

Во првото тримесечје од 2014 година, од вкупното население на возраст од 15 до 74 години, компјутер користеле 67.6\%, а Интернет користеле 68.1\%. Интернет најмногу користеле учениците и студентите, односно $96.3 \%$.

\section{Графикон 7}

Корисници (15-74) на компјутер и интернет во последните 3 месеци, според ра6отниот статус (\%)

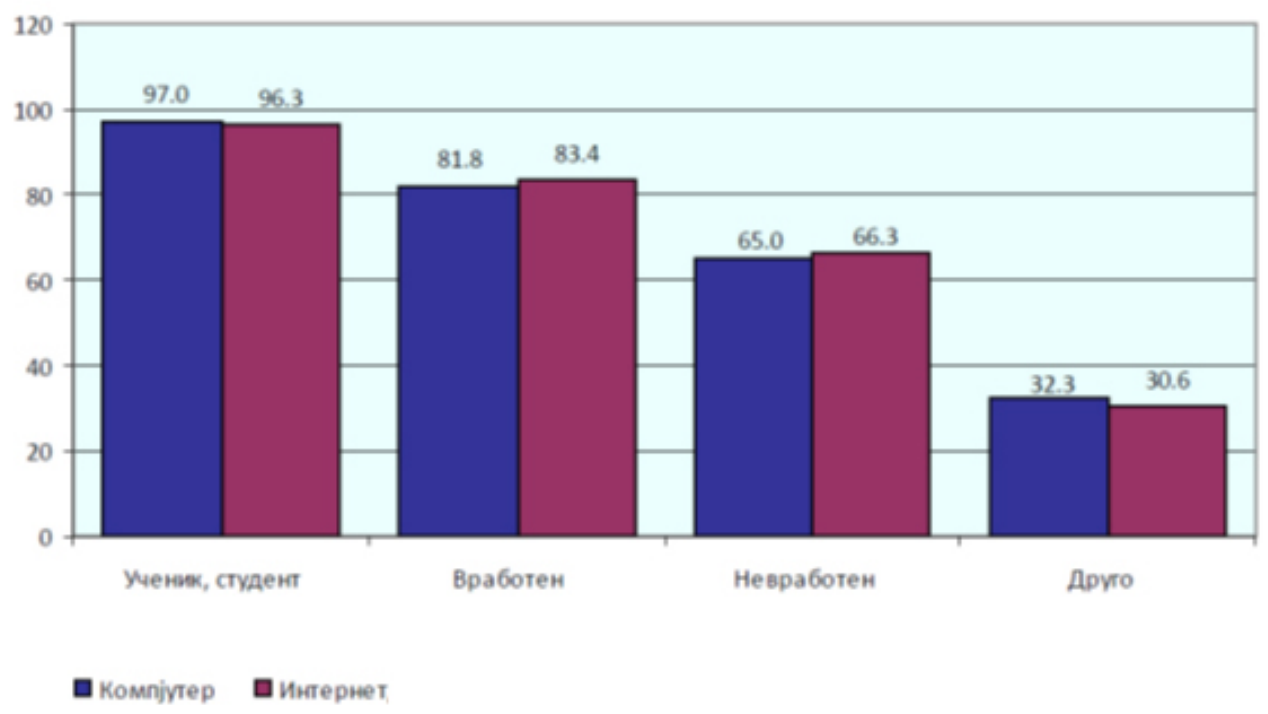

${ }^{48}$ http://www.stat.gov.mk/OblastOpsto.aspx?id=27 
Користење на информатички и комуникациски технологии во домаќинствата според типот на населеното место (во \%)

\begin{tabular}{|c|c|c|c|}
\hline & \multirow{2}{*}{ Вкупно } & \multicolumn{2}{|c|}{$\begin{array}{l}\text { Тип на населено } \\
\text { место }\end{array}$} \\
\hline & & Градско & Останато \\
\hline Домаќинства, вкупно & 100,0 & 100,0 & 100,0 \\
\hline \multicolumn{4}{|l|}{ Пристап на интернет во домот: } \\
\hline Има пристап на интернет & 68,3 & 70,0 & 65,7 \\
\hline Нема пристап на интернет & 31,4 & 29,6 & 34,2 \\
\hline Не знае дали има пристап на интернет & 0,3 & 0,4 & 0,1 \\
\hline \multicolumn{4}{|l|}{ Уреди за пристап на интернет во домот: } \\
\hline Десктоп компјутер & 54,2 & 53,3 & 55,7 \\
\hline Пренослив компјутер & 27,8 & 34,0 & 18,2 \\
\hline Друг мобилен уред (мобилен тел. или паметен тел., медија плеер и др.) & 18,9 & 19,8 & 17,5 \\
\hline Телевизор поврзан на интернет (смарт ТВ) & 2,6 & 2,9 & 2,1 \\
\hline Конзола за игри & 0,7 & 0,9 & 0,3 \\
\hline \multicolumn{4}{|l|}{ Тип на интернет-поврзаност во домот: } \\
\hline Широкопојасно поврзување (фиксно или мобилно) & 67,7 & 69,7 & 64,7 \\
\hline $\begin{array}{l}\text { Фиксно широкопјасно поврзување (пр., xDSL, ADSL, кабелско, оптичко влакно, } \\
\text { сателит, јавен WiFi) }\end{array}$ & 66,6 & 68,8 & 63,1 \\
\hline $\begin{array}{l}\text { Мобилно широкопојасно поврзување, преку мобилна телефонска мрежа, } \\
\text { најмалку } 3 G \text { (пр., UMTS) }\end{array}$ & 9,0 & 8,9 & 9,2 \\
\hline $\begin{array}{l}\text { Мобилно теснопојасно поврзување, помалку од } 3 \mathrm{G} \text { (пр. 2G+/GPRS) употребувајќи } \\
\text { мобилен тел./паметен телфон или модем во лаптоп }\end{array}$ & 5,2 & 4,1 & 6,8 \\
\hline \multicolumn{4}{|l|}{ Причини за немање поврзување на интернет во домот } \\
\hline Домаќинства кои немаат пристап на интернет & 100,0 & 100,0 & 100,0 \\
\hline Има пристап на друго место & 4,8 & 5,5 & 3,9 \\
\hline Нема потреба & 59,7 & 64,6 & 53,1 \\
\hline Цената на опремата е многу висока & 27,5 & 20,5 & 36,8 \\
\hline Цената на пристапот на интернет е многу висока & 24,1 & 16,0 & 35,1 \\
\hline Недостиг на искуство или умешност & 50,5 & 50,4 & 50,7 \\
\hline Загриженост за приватноста или безбедноста & 0,7 & 0,3 & 1,3 \\
\hline Нема широкопојасен интернет во областа & 0,2 & 0,3 & - \\
\hline Друго & 6,4 & 7,2 & 5,3 \\
\hline
\end{tabular}

табела 2

Користење на интернет во последните 3 месеци, по пол и по возраст (во \%) 


\begin{tabular}{|c|c|c|c|c|c|c|}
\hline & \multirow{2}{*}{ Вкупно } & \multicolumn{2}{|c|}{ Пол } & \multicolumn{3}{|c|}{ Возрасни групи } \\
\hline & & Машки & Женски & $15-24$ & $25-54$ & $55-74$ \\
\hline $\begin{array}{l}\text { Корисници на интернет во последните } 3 \text { месеци }{ }^{1)} \\
\text { Честота на користење на интернет во последните } 3 \text { месеци }\end{array}$ & 100,0 & 100,0 & 100,0 & 100,0 & 100,0 & 100,0 \\
\hline Секој ден & 78,1 & 79,5 & 76,5 & 95,1 & 74,7 & 58,7 \\
\hline Најмалку еднаш неделно & 16,9 & 15,8 & 18,1 & 4,9 & 19,0 & 31,9 \\
\hline Помалку од еднаш неделно & 5,1 & 4,7 & 5,4 & - & 6,3 & 9,4 \\
\hline $\begin{array}{l}\text { Активности на интернет во последните } 3 \text { месеци } \\
\text { Праќање или примање електронска пошта }\end{array}$ & 66,1 & 68,9 & 63,0 & 85,1 & 60,6 & 55,0 \\
\hline Телефонирање преку интернет/видео повици преку вебкам & 67,8 & 62,4 & 73,9 & 79,9 & 62,0 & 75,0 \\
\hline Учество во социјални мрежи & 79,8 & 78,9 & 80,8 & 94,4 & 79,2 & 49,8 \\
\hline Читање/симнување он-лајн новини/весници/списанија & 67,3 & 72,1 & 62,1 & 74,5 & 63,6 & 73,2 \\
\hline Наоѓање информации за производи/услуги & 61,4 & 63,9 & 58,7 & 76,2 & 57,8 & 49,0 \\
\hline Слушање веб-радио или гледање веб-телевизија & 44,0 & 47,1 & 40,6 & 70,4 & 36,8 & 26,4 \\
\hline Играње/симнување игри, слики, филмови или музика & 43,4 & 50,7 & 35,3 & 73,4 & 37,1 & 11,4 \\
\hline Играње мрежни игри со други лица & 15,1 & 20,5 & 9,1 & 30,4 & 11,0 & 3,8 \\
\hline $\begin{array}{l}\text { Ставање на лично креирана содржина (текст, слики, видеа, } \\
\text { музика и др.) на веб-страници за да бидат споделени }\end{array}$ & 20,0 & 19,4 & 20,6 & 36,1 & 15,6 & 8,5 \\
\hline Креирање на веб-страници или блогови & 3,6 & 3,9 & 3,2 & 7,7 & 2,4 & 1,1 \\
\hline $\begin{array}{l}\text { Закажување на лекар преку веб-страници (пр., во болница или } \\
\text { здравствен центар) }\end{array}$ & 2,9 & 2,8 & 3,1 & 1,1 & 3,2 & 5,9 \\
\hline Користење на услуги поврзани со патување и сместување & 14,7 & 13,1 & 16,5 & 16,7 & 16,0 & 2,6 \\
\hline Продажба на производи/услуги, на пр.: преку аукции (еВау) & 5,1 & 4,2 & 6,0 & 9,4 & 4,1 & 0,9 \\
\hline Интернет-банкарство & 12,5 & 12,9 & 12,1 & 15,4 & 12,4 & 6,7 \\
\hline $\begin{array}{l}\text { Употребиле облак-услуги (складишно место на интернет) } \\
\text { Употребиле складишно место на интернет за зачувување } \\
\text { или споделување на следното: }\end{array}$ & 17,6 & 17,3 & 17,9 & 28,7 & 15,3 & 6,2 \\
\hline Текст, табела или електронска презентација & 6,6 & 7,5 & 5,6 & 7,1 & 7,1 & 2,6 \\
\hline Фотографии & 15,4 & 15,3 & 15,5 & 26,5 & 12,7 & 5,3 \\
\hline Е-книги или е-магазини & 2,3 & 3,5 & 1,0 & 1,8 & 2,8 & 1,0 \\
\hline Музика & 11,6 & 11,6 & 11,7 & 22,1 & 9,1 & 2,1 \\
\hline Видеа (вкл. филмови, ТВ програми) & 7,6 & 8,2 & 6,9 & 12,4 & 6,5 & 2,7 \\
\hline Друго & 0,9 & 1,1 & 0,8 & 0,6 & 1,1 & 0,5 \\
\hline
\end{tabular}

1) Периодот "последните 3 месеци" е првото тримесечје од годината 
55.2\% од корисниците на интернет во првото тримесечје од 2014 година употребиле мобилен телефон или паметен телефон за пристап на Интернет надвор од дома или работа.

Табела 3

Мобилна употреба на интернет во последните 3 месеци, според полот и возрасните групи (во \%)

\begin{tabular}{|c|c|c|c|c|c|c|}
\hline & \multirow{2}{*}{ Вкупно } & \multicolumn{2}{|c|}{ Пол } & \multicolumn{3}{|c|}{ Возрасни групи } \\
\hline & & Машки & Женски & $\begin{array}{l}15- \\
24\end{array}$ & $\begin{array}{l}25- \\
54\end{array}$ & $\begin{array}{l}55- \\
74\end{array}$ \\
\hline Корисници на интернет во последните 3 месеци ${ }^{1)}$ & 100,0 & 100,0 & 100,0 & 100,0 & 100,0 & 100,0 \\
\hline $\begin{array}{l}\text { Употребиле мобилен телефон или паметен телефон за } \\
\text { пристап до интернет надвор од дома/работа }\end{array}$ & 55,2 & 58,6 & 51,5 & 78,4 & 52,3 & 18,8 \\
\hline - преку мобилна тел.мрежа (пр., GPRS, UMTS) & 39,3 & 42,3 & 36,0 & 58,3 & 36,8 & 10,2 \\
\hline - преку безжична мрежа (пр., јавен WiFi) & 39,6 & 40,9 & 38,2 & 62,3 & 34,8 & 15,8 \\
\hline $\begin{array}{l}\text { Употребиле пренослив компјутер (пр., лаптоп, таблет) за } \\
\text { пристап до интернет надвор од дома/работа }\end{array}$ & 19,2 & 18,5 & 20,1 & 32,6 & 14,8 & 15,0 \\
\hline - преку мобилна тел.мрежа со USB или SIM картичка & 11,5 & 10,8 & 12,4 & 24,3 & 7,0 & 9,4 \\
\hline - преку безжична мрежа (пр., јавен WiFi) & 16,3 & 14,9 & 17,9 & 26,8 & 12,8 & 13,0 \\
\hline $\begin{array}{l}\text { Употребиле други мобилни уреди за пристап до интернет } \\
\text { надвор од дома/работа }\end{array}$ & 0,3 & 0,6 & - & 0,5 & 0,3 & - \\
\hline $\begin{array}{l}\text { Не употребиле мобилен уред за пристап до интернет } \\
\text { надвор од дома/работа }\end{array}$ & 40,5 & 36,9 & 44,6 & 16,1 & 44,4 & 74,2 \\
\hline
\end{tabular}

1) Периодот "последните 3 месеци" е првото тримесечје од годината

Според податоците на Државниот завод за статистика, во јануари 2014 година, широкопојасен пристап на Интернет (преку фиксна или мобилна конекција) имале 93.1\% од деловните субјекти со десет или повеќе вработени. Пристап на Интернет преку мобилна конекција (широкопојасна или друг вид на мобилна конекција) имале 59.3\% од деловните субјекти. 60.7\% од деловните субјекти на своите вработени им обезбедиле преносливи уреди со кои се овозможува мобилна конекција на интернет за деловна употреба, но само 10\% од вработените во деловните субјекти ги користеле овие уреди. 
Информатичко-комуникациски технологии во деловните субјекти според бројот на вработени, 2014

\begin{tabular}{|c|c|c|c|c|}
\hline & \multirow{2}{*}{$\begin{array}{l}\text { Вкупно } \\
(10+)\end{array}$} & \multicolumn{3}{|c|}{$\begin{array}{l}\text { Деловни субјекти според } \\
\text { бројот на вработени }\end{array}$} \\
\hline & & $(10-49)$ & $\begin{array}{l}(50- \\
249)\end{array}$ & $(250+)$ \\
\hline Деловни субјекти, вкупно & 100,0 & 100,0 & 100,0 & 100,0 \\
\hline Деловни субјекти со компјутер & 94,6 & 93,9 & 98,3 & 99,0 \\
\hline Деловни субјекти со пристап на интернет & 93,1 & 92,1 & 98,3 & 99,0 \\
\hline $\begin{array}{l}\text { - преку фиксна широкопојасна конекција (DSL, кабелска, оптичка или др. } \\
\text { технологија) }\end{array}$ & 92,1 & 90,9 & 98,1 & 99,0 \\
\hline $\begin{array}{l}\text { - преку мобилна телефонска мрежа (широкопојасна или друга мобилна } \\
\text { конекција) }\end{array}$ & 59,3 & 57,1 & 68,2 & 80,2 \\
\hline Широкопојасна конекција (фиксна или мобилна) & 93,1 & 92,0 & 98,3 & 99,0 \\
\hline $\begin{array}{l}\text { На вработените им обезбедиле преносливи уреди кои овозможуваат } \\
\text { мобилна конекција на интернет }\end{array}$ & 60,7 & 58,5 & 69,3 & 81,8 \\
\hline Имаат своја веб-страница или почетна страница & 53,2 & 49,8 & 66,2 & 88,5 \\
\hline - веб-страницата обезбедува онлајн нарачување, резервирање & 12,4 & 12,2 & 13,7 & 11,8 \\
\hline
\end{tabular}

\section{Графикон 8}

Вработени кои користеле компјутер и интернет во деловните субјекти според 6ројот на вработени, 2014

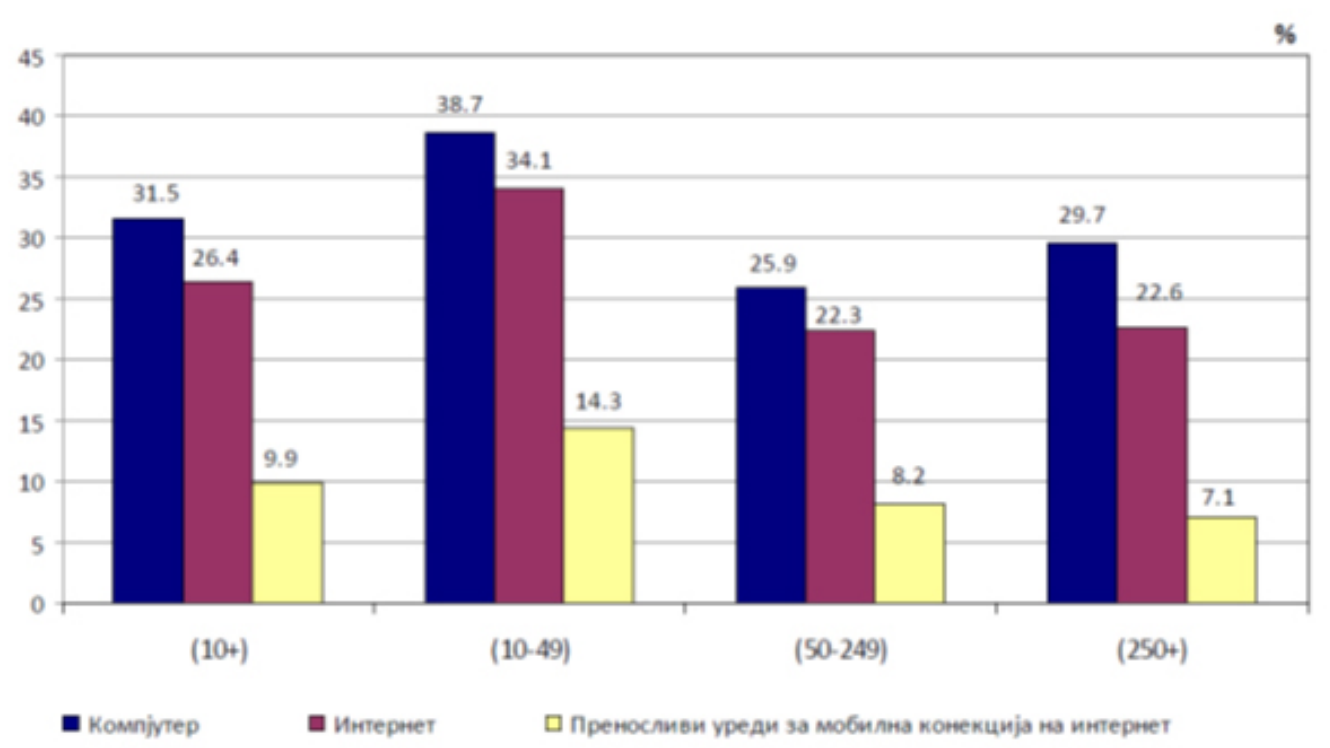




\section{3. Истражување на мислењето на корисниците}

Ниеден успешен проект од областа на веб дизајнот, па и пошироко, не може да се замисли без да се осознае мислењето на можните идни корисници во фазата на истражување. Така, по извршениот преглед на статистичките податоци, следи анализата на резултатите добиени од истражувањето на мислењето на корисниците.

Ова истражување беше спроведено со помош на онлајн платформата за анкетирање Kwiksurveys ${ }^{49}$. Прашалникот беше составен од вкупно 18 затворени прашања, формулирани со цел да се добијат информации за корисниците, нивните преференции и нивните навики. За период од еден месец беа анкетирани вкупно 76 лица.

На почетокот беа поставени неколку прашања за да се добијат некои основни демографски податоци за корисниците, како што се полот, возраста и социјалниот статус. Се трудев да има приближно еднаква полова застапеност, сепак постои разлика од 6 испитаника, така што женскиот пол е поброен (53,95\%) од машкиот (46,05\%). Во однос на возраста, во анкетата беа опфатени испитаници од скоро сите возрасни групи. Најбројни беа испитаниците во возрасната група од 19 до 24 години, кои беа застапени со 31,58\%. Блиску до нив беа испитаниците во возрасната група од 46 до 65 години (22,37\%) и испитаниците во возрасната група од 25 до 35 години (19,74\%), а помалку испитаниците имаше во останатите возрасни групи. Возрасната група над 65 години не беше опфатена и следствено немаше ниту еден испитаник со социјален статус пензионер. Први по застапеност беа вработените со 55,26\%, втори беа студентите/учениците (31,58\%), а најмалку од испитаниците беа со социјален статус невработен (13,16\%).

Веќе од четвртото прашање, „Колку време поминувате на Интернет дневно?“, почнав да ги испитувам навиките на корисниците. Најголемиот дел од испитаниците т.е. 39 од нив одговориле дека поминуваат 2 до 5 часа на Интернет дневно. 30 испитаници поминуваат повеќе од 6 часа на Интернет дневно, а само 7 испитаника одговориле дека поминуваат помалку од 1 час на Интернет дневно.

\footnotetext{
${ }^{49}$ https://kwiksurveys.com/
} 


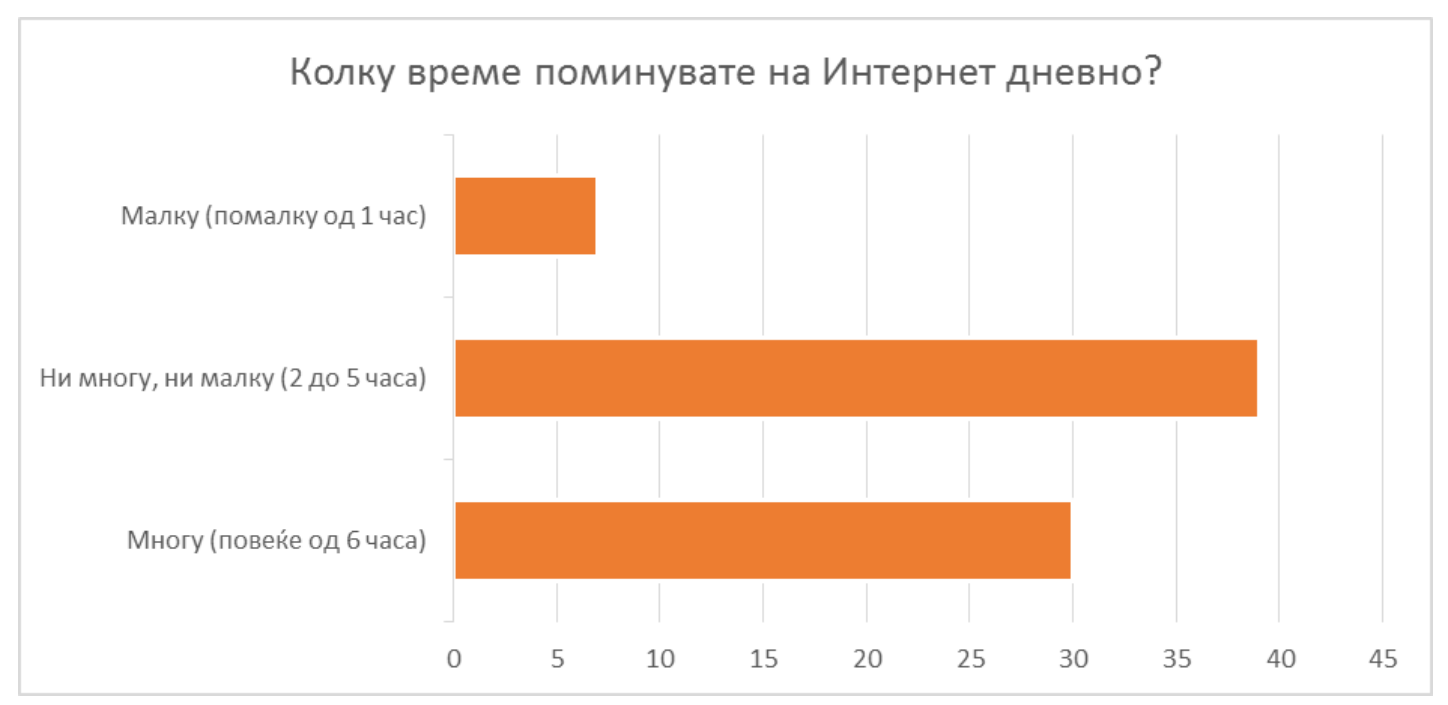

Графикон 9

Со следното прашање, „Дали воопшто пристапувате на Интернет од мобилни уреди?“, се изврши поделба на корисниците. 68 од нив одговорија позитивно, а само 8 се изјаснија дека воопшто не користат мобилни уреди за да пристапат на интернет. Од ова може јасно да се согледа оправданоста за употреба на прилагодлив веб дизајн за да можат да се опслужат повеќе уреди истовремено. Од оние кои одговорија позитивно, беше побарано да одговорат две дополнителни прашања за да се открие каков оперативен систем користи нивниот мобилен уред и кои се нивните преференции во однос на прегледувањето на информациите. Па така, најмногу од испитаниците кои користат мобилни уреди за да пристапат до Интернет, користат уреди кои го имаат оперативниот систем Android на компанијата Google односно 76,47\%. Многу помалку корисници користат мобилни уреди на компанијата Apple кои имаат оперативен систем IOS или 16,18\%, а најмалку користат уреди со оперативен систем Microsoft Windows Phone (4,41\%) или некој друг (2,94\%). Според тоа, доколку во иднина се размислува да се развива некаква апликација, пред сѐ треба да се насочат дизајнерските цели кон Android интерфејс, а програмерските цели кон искористување на придобивките на овој оперативен систем. 
Каков оперативен систем има Вашиот мобилен уред?

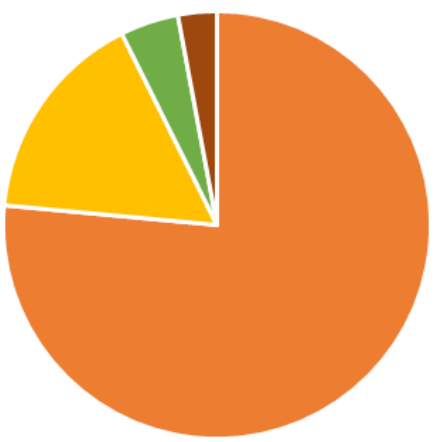

Графикон 10

Постои скоро еднаква поделеност во мислењето на корисниците во однос на тоа на кој начин сакаат да ги прегледуваат информациите поставени на Интернет. 25\% од испитаниците сакаат да ги прегледуваат информациите преку соодветна апликација, а нешто помалку 22,06\% преку прегледник. Како и да е, на најголемиот дел, односно на 52,94\% не им прави разлика начинот. Ова повторно го оправдува пристапот во оваа задача за создавање веб локација со прилагодлив дизајн, наместо на поскапата варијанта на мобилна апликација (заради потребата од повеќе слични апликации за различните оперативни системи и мобилни уреди).

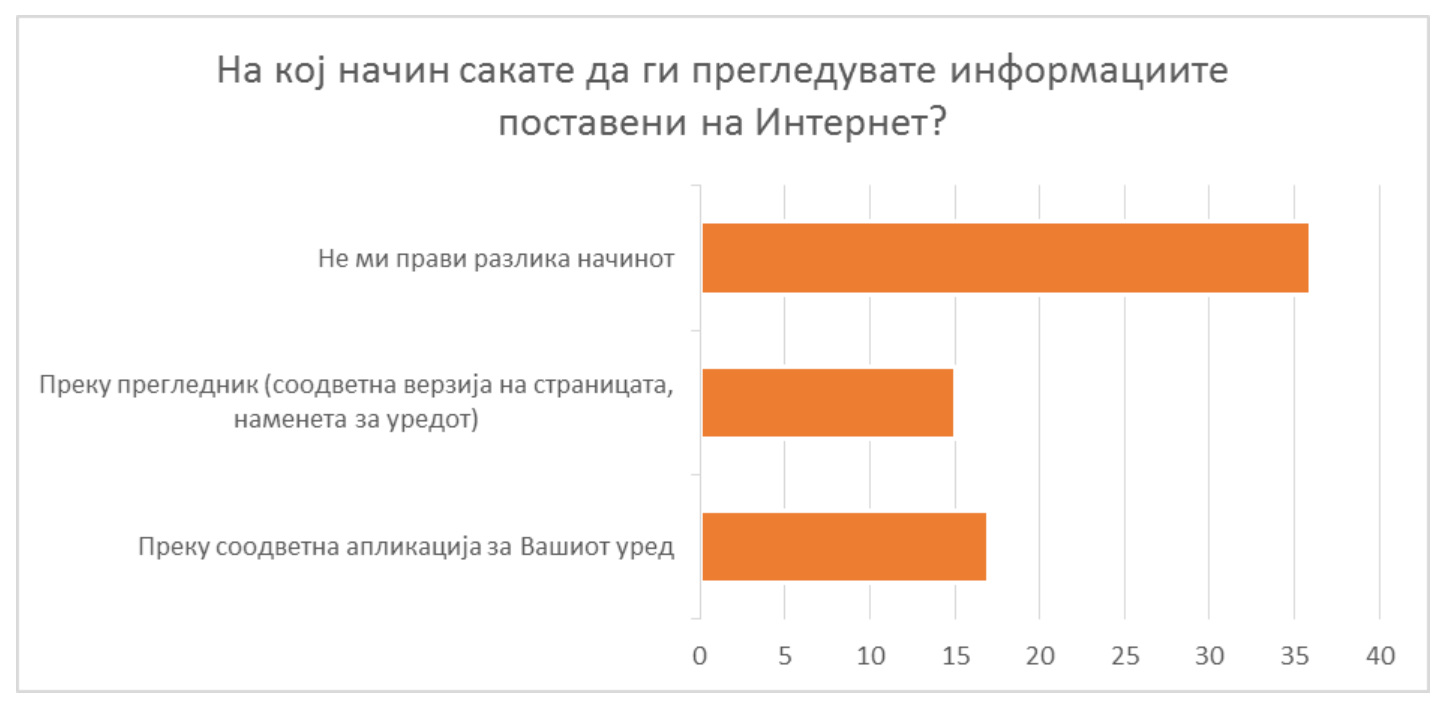

Графикон 11 
Сите испитаници (и оние кои воопшто не користат мобилни уреди) продолжуваа да одговараат на прашањето под реден број 8. На ова прашање испитаниците требаше да одберат од кој од трите понудени уреди (Персонален компјутер, Таблет или Мобилен телефон) најчесто пристапуваат на Интернет. Очекувано, најмногу од испитаниците (47 испитаници) најчесто користат персонален компјутер за да пристапат на Интернет. Меѓутоа, бројот од 25 испитаници кои најчесто пристапуваат на Интернет од мобилен телефон не е за занемарување. Најмалку корисници пристапуваат на Интернет од таблет. Импликациите од ова прашање се врз прилагодувањето на изгледот во однос на резолуцијата на уредите и на кои уреди треба да се посвети повеќе внимание при програмирањето на веб страниците.

Следното прашање беше поставено со цел да се дознае кој прегледник најчесто го користат корисниците, за да може да се искористат некои специфични карактеристики при програмирањето на веб страниците. Од добиените одговори може да се забележи дека најупотребуван е прегледникот Google Chrome co 69,74\%, следен од Mozilla Firefox co 19,74\%, а изненадувачки трет е прегледникот Internet Explorer co 6,58\%. Останатите прегледници добиле по еден одговор.

\section{Кој прегледник најчесто го користите?}

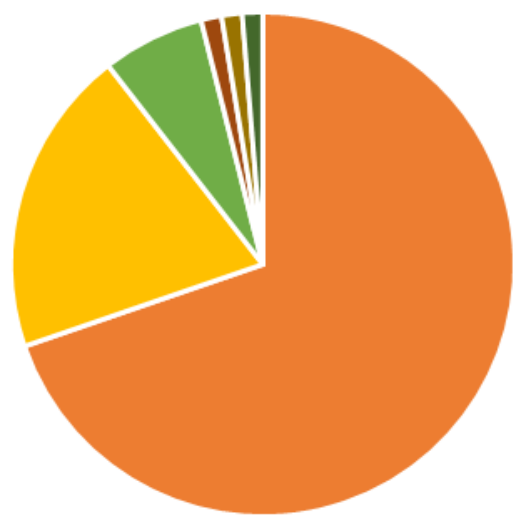

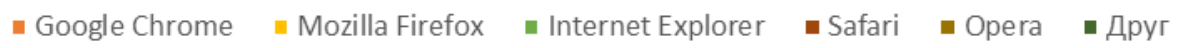


Слични резултати се добија и на следното прашање, од кога испитаниците беше побарано да ги рангираат понудените прегледници според нивните преференции. Повторно убедливо водство има прегледникот Google Chrome co најмногу одговори со оцена 5, на второ место по популарност е прегледникот Mozilla Firefox со најмногу одговори со оцена 4, а сите останати прегледници добиле најмногу одговори со оцена 1.

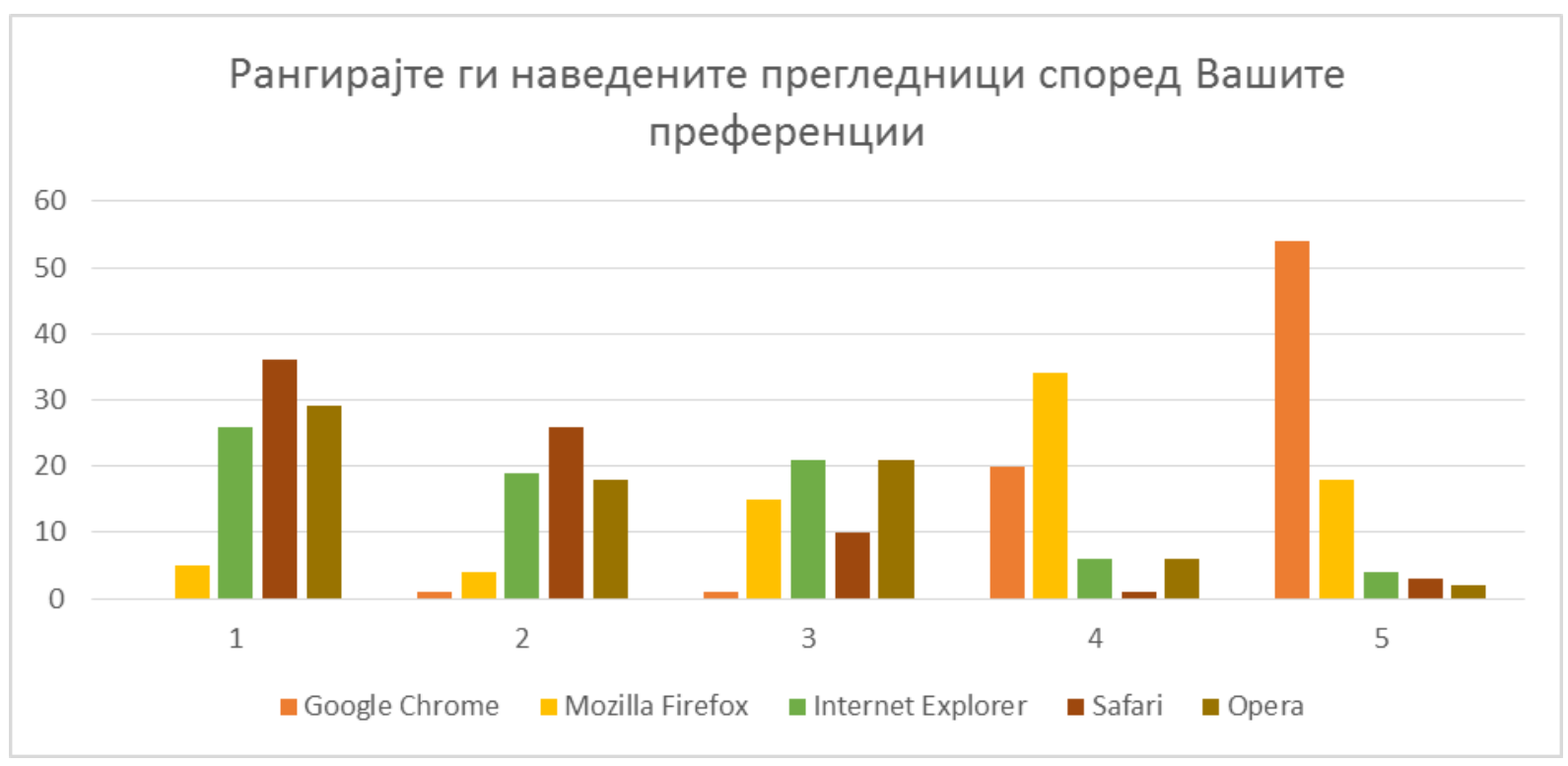

Графикон 13

Со прашањето „Како го поминувате Вашето време на Интернет?“ сакав да ги откријам навиките на корисниците додека се на Интернет. $36,84 \%$ од испитаниците го поминуваат своето време на Интернет прегледувајќи веб страници (за забава или информативни цели), најмалку играјќи игри, а ниеден од испитаниците не го користи своето време на Интернет прегледувајќи интернет продавници (со цел купување/продавање производи). 26,32\% го поминуваат своето време на социјални медиуми (Facebook, Twitter и сл.), помалку го поминуваат своето време на Интернет за деловни цели или комуницирајќи (преку одреден софтвер или Е-пошта), а уште помалку од испитаниците го поминуваат своето време за научно-истражувачки цели. Од ова прашање може да се извлече насока во однос на промовирањето, поконкретно на рекламирањето на веб локацијата која ќе се изработи кај веб страници кои се со 
информативни или забавни содржини (бидејќи тие се и најпосетувани од испитаниците).

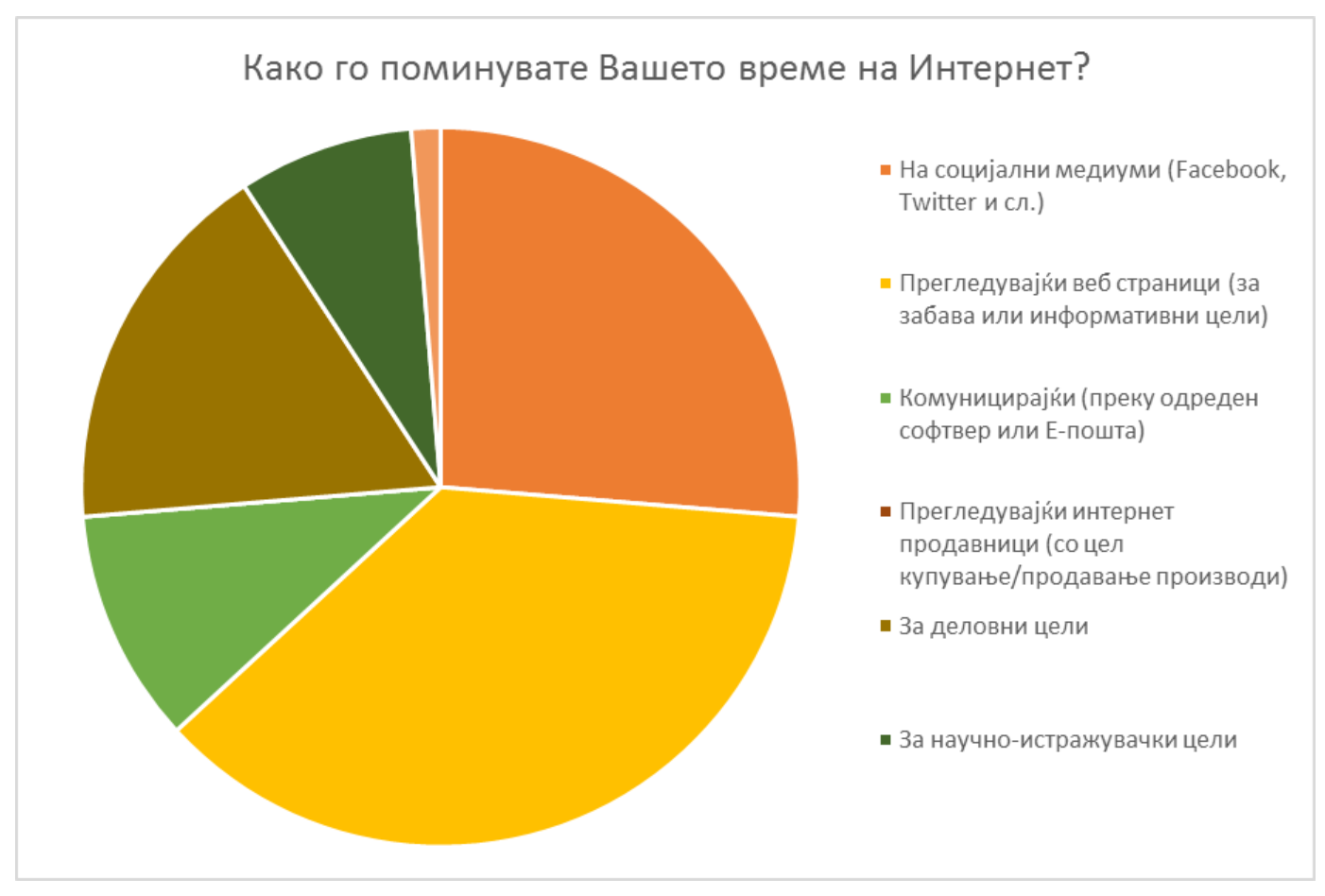

Графикон 14

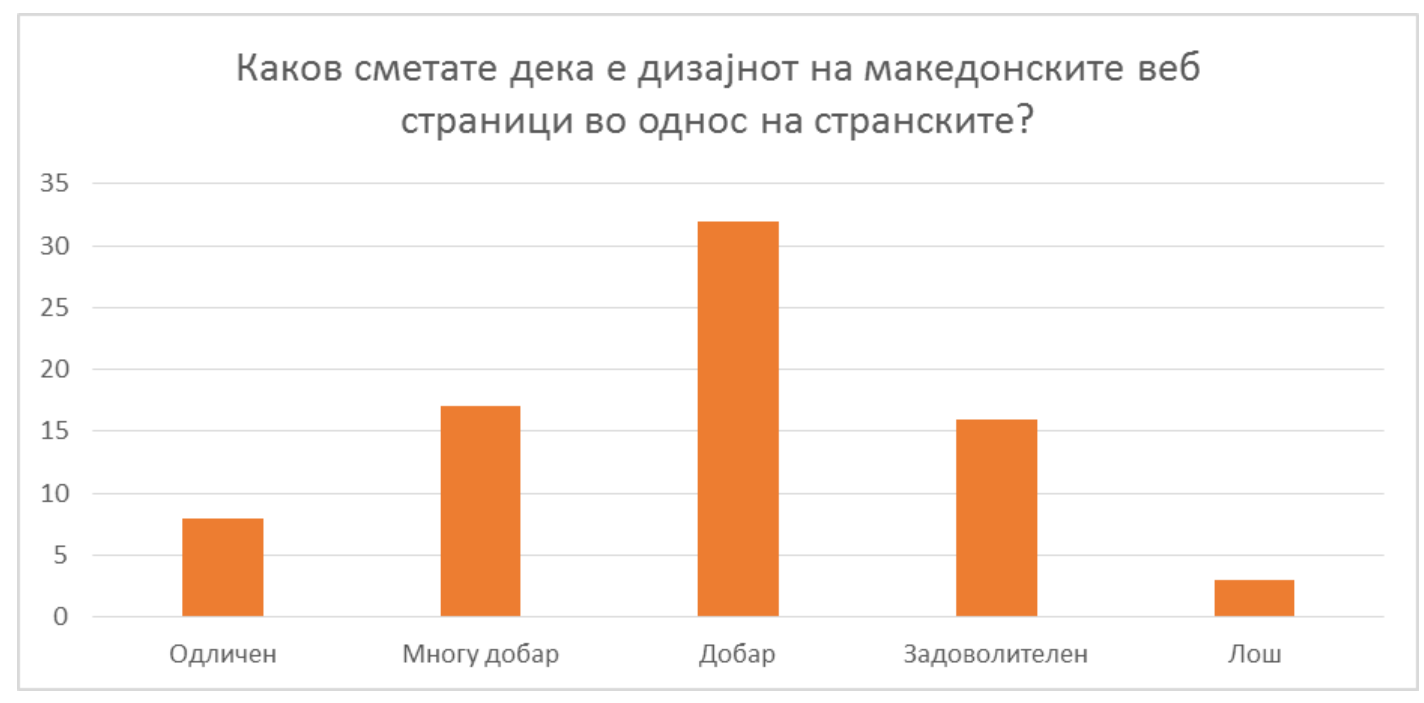

Графикон 15 
На прашањето каков сметаат дека е дизајнот на македонските веб страници во однос на странските, најмногу испитаници (42,11\%) одговориле добар. Скоро поделени биле мислењата на испитаниците дали е многу добар (22,37\%) или задоволителен $(21,05)$, а помалку одговориле дека е одличен $(10,53 \%)$ односно лош (3,95\%). Многумина го прифаќаат сегашниот стил на дизајнирање на веб страниците во Македонија, но тоа не значи дека не може да се направи нешто повеќе и нешто подобро.

Понатаму целта беше да се дознае што им е најважно на испитаниците кај една веб страница. Највеќе испитаници или 46,05\% одговориле дека организираноста на информациите им е најважна кај една веб страница. Блиску до нив се испитаниците кои одговориле дека квалитетот на содржината им е најважен $(39,47 \%)$. Додека на помалку испитаници им е важна можноста соодветно да се прегледува на повеќе уреди (11,84\%), односно дизајнот (2,63\%). На ниеден испитаник можноста да се дебатира на одредена тема (преку коментари) не му е вреднувана како најважна. Следствено, ова укажува на фактот дека највеќе треба да се посвети внимание на организираноста и квалитетот на информациите при изработката на задачата.

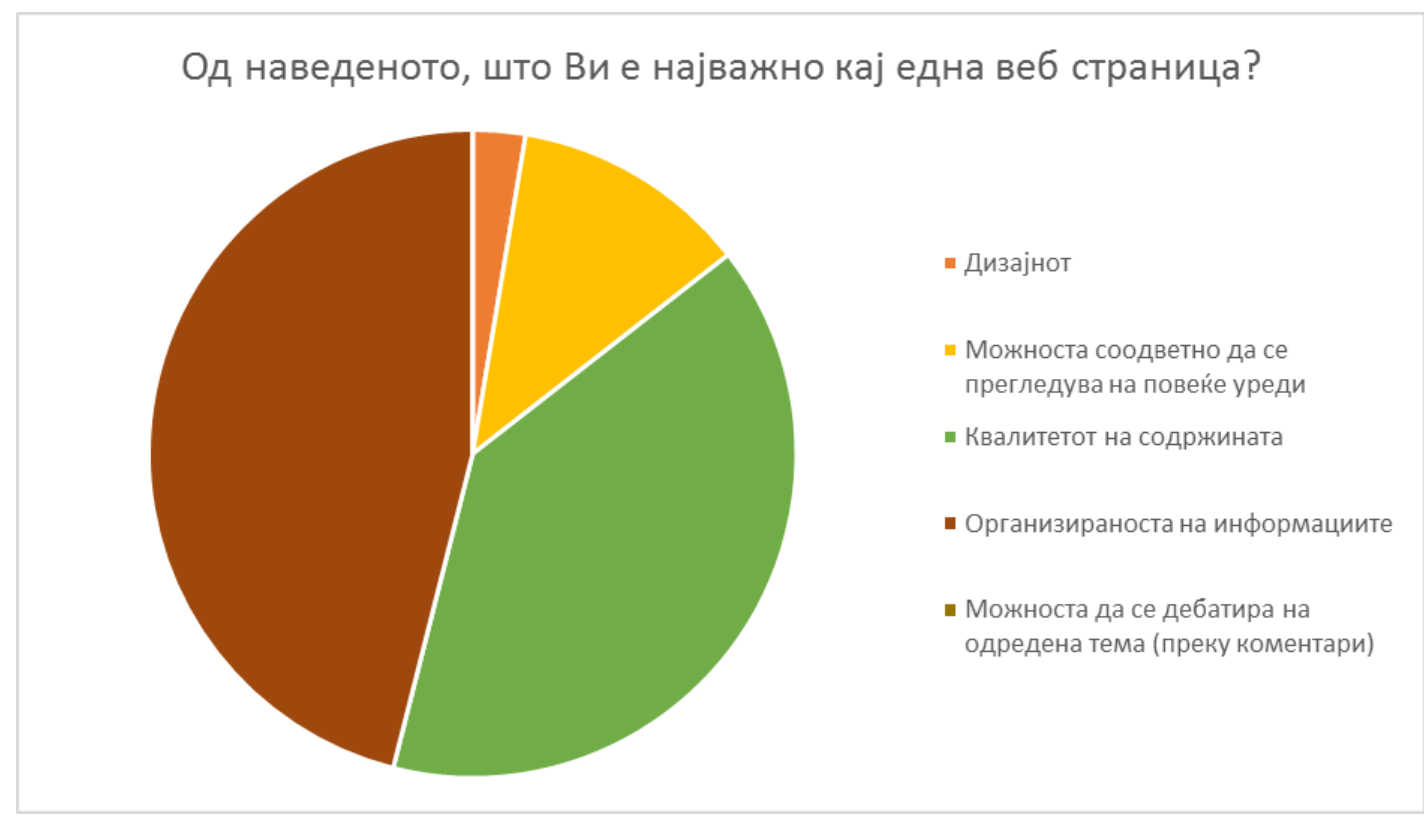

Графикон 16 
Со следното прашање се дозна нешто повеќе околу однесувањето на испитаниците, поконкретно за причините заради што најчесто ги напуштаат веб страниците. Најчеста причина заради која испитаниците ги напуштаат веб страниците е неможноста за пронаоѓање на бараната информација $(57,89 \%)$, а најретки причини за напуштање се лошиот дизајн (3,95\%) и многуте анимирани елементи на страницата (3,95\%). 17,11\% од испитаниците ги напуштаат веб страниците заради премногу простор отстапен за реклами, а уште помалку заради малата брзина на пристапување до страницата (побарување многу хардверски ресурси) или лошото корисничко искуство (несоодветност при прегледување од одреден уред). Од добиените одговори може да се заклучи дека од огромно значење за задржувањето на посетителите на веб страницата е можноста брзо и едноставно да ги најдат бараните информации. Ова директно влијае на организираноста на веб локацијата и на распоредот на содржините на поединечните страници.

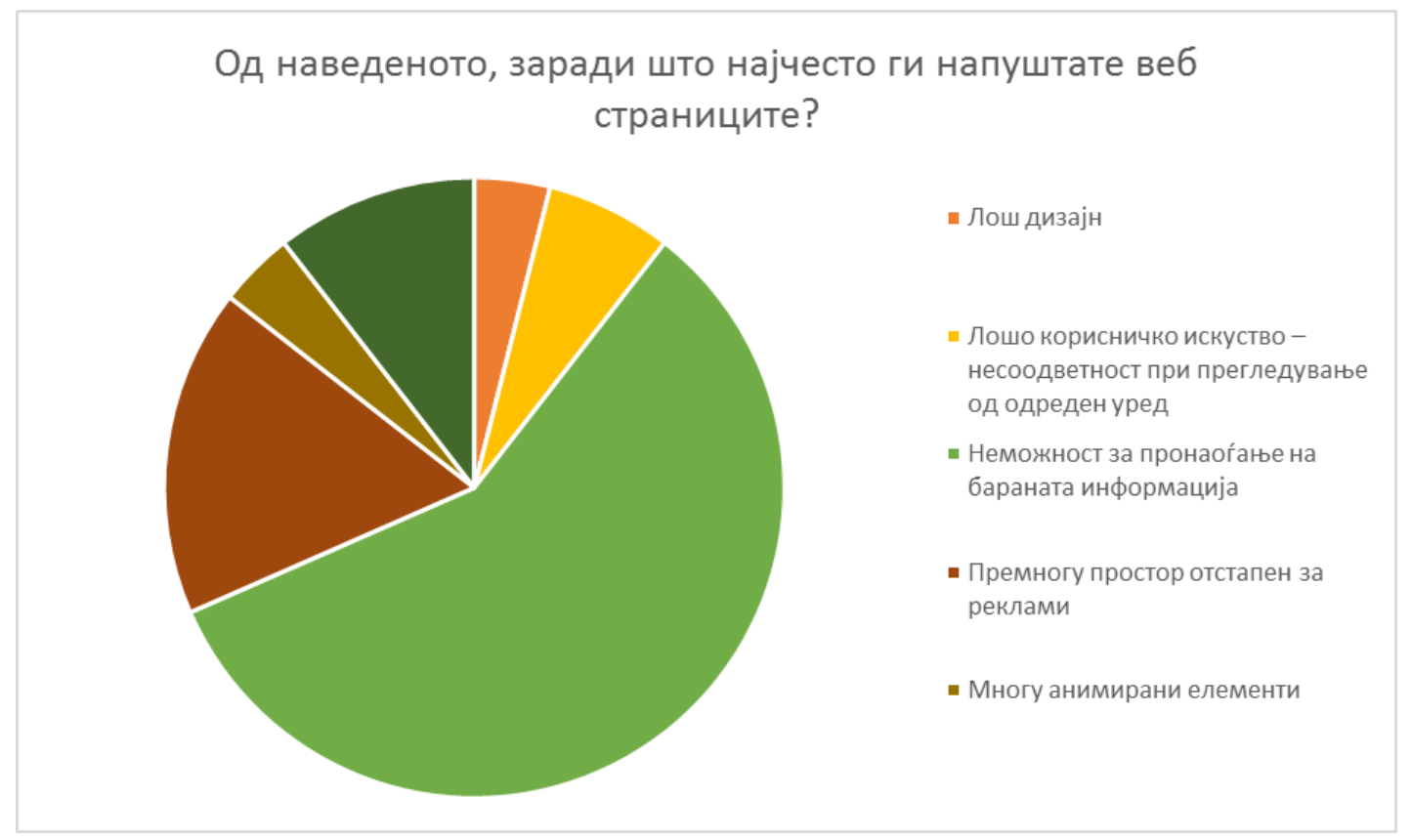

Графикон 17

Целата на последните неколку прашања беше откривање на најдобрата насока за промовирање и подигнување на свесноста за постоење на центар за трансфер на технологии во Македонија. Па така, прашањето под реден број 15, даде одговор за тоа 
каде пребаруваат испитаниците за да стекнат одредена информација доколку им е потребна некаква услуга. Најпопуларен медиум според нив е Интернетот, дури 93,42\% се изјасниле дека пребаруваат информации на Интернет доколку им е потребна некаква услуга. Многу помалку бараат информации во имениците (пр. „Златна книга“, „АБВ“, „Yellow Pages“ и сл.) или во печатените медиуми. Ова значи дека присуството на Интернет е клучно за успехот на една компанија.

При одлучувањето каде да им биде извршена одредена услуга, на највеќе испитаници (64,47\%) пресуден им е квалитетот при извршувањето на услугата. Компетентноста на кадарот кој ја извршува услугата помалку влијае врз одлуката на испитаниците, а најмалку влијаат цената за извршувањето на услугата, мислењето на другите луѓе за извршителот на услугата и стекнатото искуство на извршителот на услугата. Ова укажува дека при составувањето на содржините наменети за веб локацијата која ќе се изработува и за промоцијата, потребно е да се стави акцент на квалитетот при извршувањето на услугата и компетентноста на кадарот кој ја извршува услугата. Тоа може да се постигне на најразлични начини, но сметам дека е најефективно преку разни акредитации, сведоштва на клиенти и приложени материјали од завршени проекти.

При одлучувањето каде да Ви биде извршена одредена услуга, што Ви е пресудно?

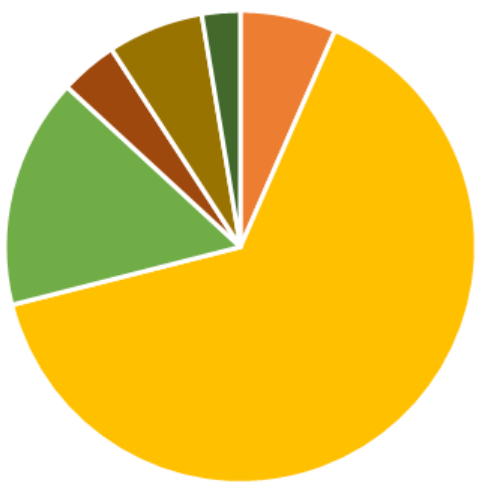

- Цената за извршувањето на услугата

= Квалитетот при извршувањето на услугата

- Компетентноста на кадарот кој ја извршува услугата

- Стекнатото искуство на извршителот на услугата

- Мислењето на другите луѓе за извршителот на услугата

- Друго

Графикон 18 
Освен што е најкористен за стекнување одредени потребни информации, Интернетот остава и најголем впечаток кај испитаниците $(81,58 \%)$ во однос на информирање за постоењето на некој производ или услуга. На второ место е телевизијата (13,16\%), а третото место го делат радиото и печатените медиуми $(2,63 \%)$. Може слободно да се заклучи дека најефективно би било рекламирањето на Интернет страниците (пр. преку веб банери).

Последното прашање беше поставено за да се осознае свесноста на луѓето за постоењето на центар за трансфер на технологии во Македонија. За жал најголемиот дел од испитаниците дури 89,47\% не се запознаени со поимот „центар за трансфер на технологии“. Следствено, исклучително важно е паралелно со промовирањето да се подигне свесноста и да се запознаат луѓето со намената и можностите на конкретниот центар за трансфер на технологии. 


\section{4. Анализа на актуелните трендови во веб дизајнот}

Дизајнот е огледало на културата. Промените во општеството, технологијата и уметноста секогаш се одразуваат врз моменталната состојба на дизајнот. Веб дизајнот е најдинамичниот член во дизајнот. Низ годините можеше да се забележи огромен интерес да се прикажат одредени елементи со доста реалистичен изглед (во однос на формата и материјалот т.н. skeuomorphism), имаше широка употреба на предимензионирана типографија или ракописни фонтови, понатаму веб страниците имаа класичен изглед, па дрвени позадини, беа со енормни наслови или енормни долни блокови итн. Денес дизајнот е различен - корисниците се во центарот на процесот. Адаптацијата на веб страниците на различни големини на екрани прерасна во стандард. Визуелниот аспект на веб дизајнот е наклонет кон едноставност и баланс. Дизајнот е созреан. Конечно, модерните веб страници имаат одлични текстови, слики и видеа. Содржината се издига над распоредот и орнаментите или со други зборови дизајнот го креира контекстот за содржината. Посетителите не ја прегледуваат веб страницата за да се восхитуваат на распоредот и целокупниот дизајн. Посетителите доаѓаат на веб локацијата за да ги постигнат нивните цели. Во најголемиот број случаи содржината е патот кон целта и заради тоа мора да биде јасна. Распоредот и дизајнот на веб страницата привлекува посетители, но тоа функционира само кога постои релевантна, корисна и занимлива содржина.

Прилагодливиот веб дизајн, кој некогаш беше револуционерна идеја, денес е секојдневие. Не станува ни збор за вообичаен тренд, туку тоа е реалноста на дизајнерското изразување. Повеќе не е прашање дали да се примени или не, туку дали може правилно да се имплементира. Живееме во еден вид пост компјутерска ера. Важноста на мобилните уреди и паметните часовници се повеќе расте и мора да се прифати фактот дека веб локациите мора да пружат соодветно искуство за различни димензии на екрани. Во 2013 година ${ }^{50}$ околу 25\% од Интернет сообраќајот се остварил од паметни мобилни телефони и таблети. Повеќе од 25\% од телевизорите продадени во 2012 година биле паметни телевизори со можност за поврзување на Интернет.

\footnotetext{
${ }^{50}$ M. Treder, R. Warych S. Witman, Web Design Book of Trends, UXPin Sp. z o.o, Gdynia, Poland, 2014.
} 
Само прилагодливиот веб дизајн може соодветно и на едноставен начин да ги опслужи сите уреди и нивните корисници.

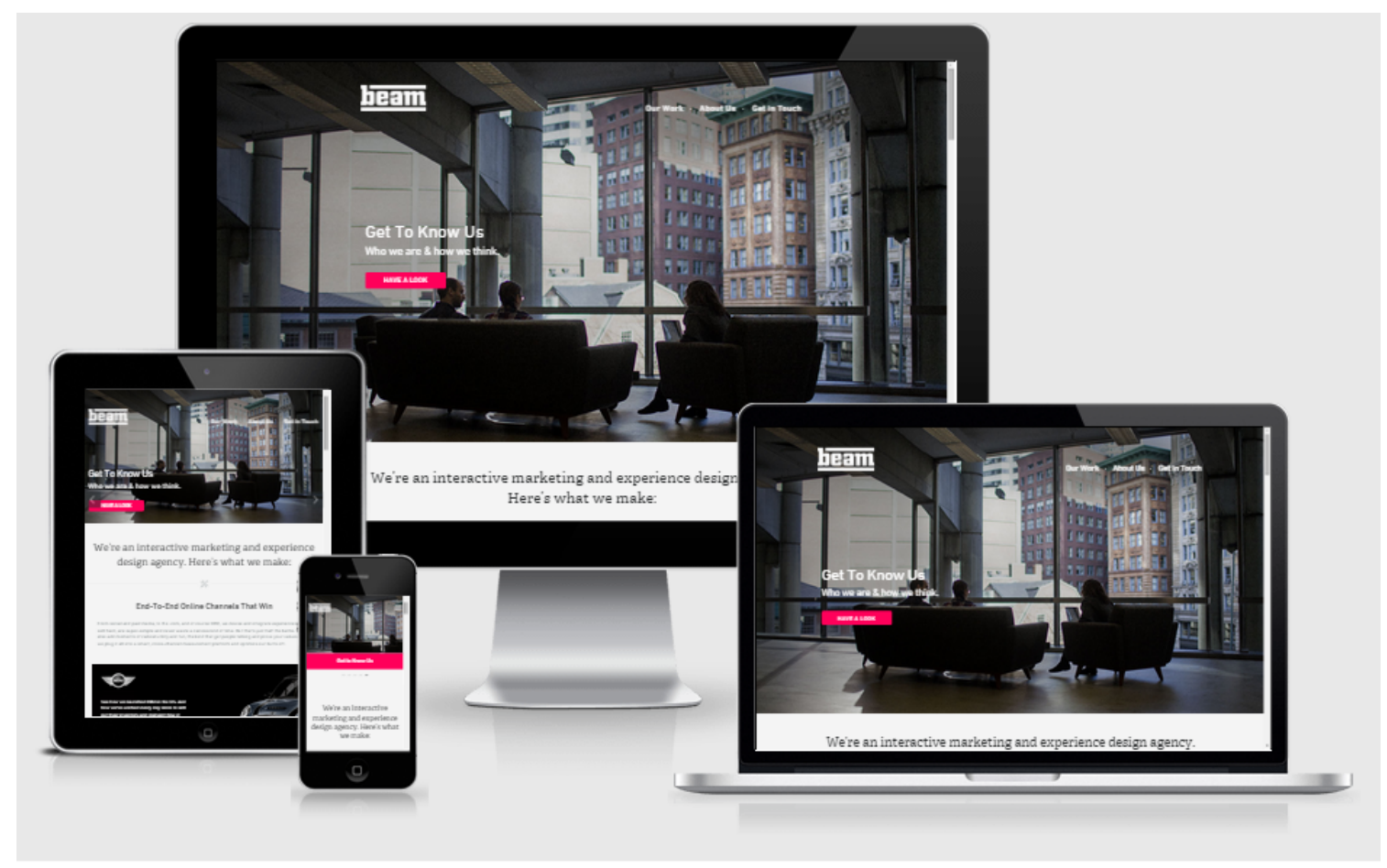

Слика 49 - Пример за прилагодлив веб дизајн

Ефектот на паралакса при движењето по веб страниците присутен е долго време, а влече корени од анимираните филмови и видео игрите. Овој ефект води кон одредена илузија на тродимензионалност во дводимензионалниот простор и создава занимлива околина за презентирање на содржината. Најчесто се употребува во комбинација со позадинска слика со висока резолуција. 


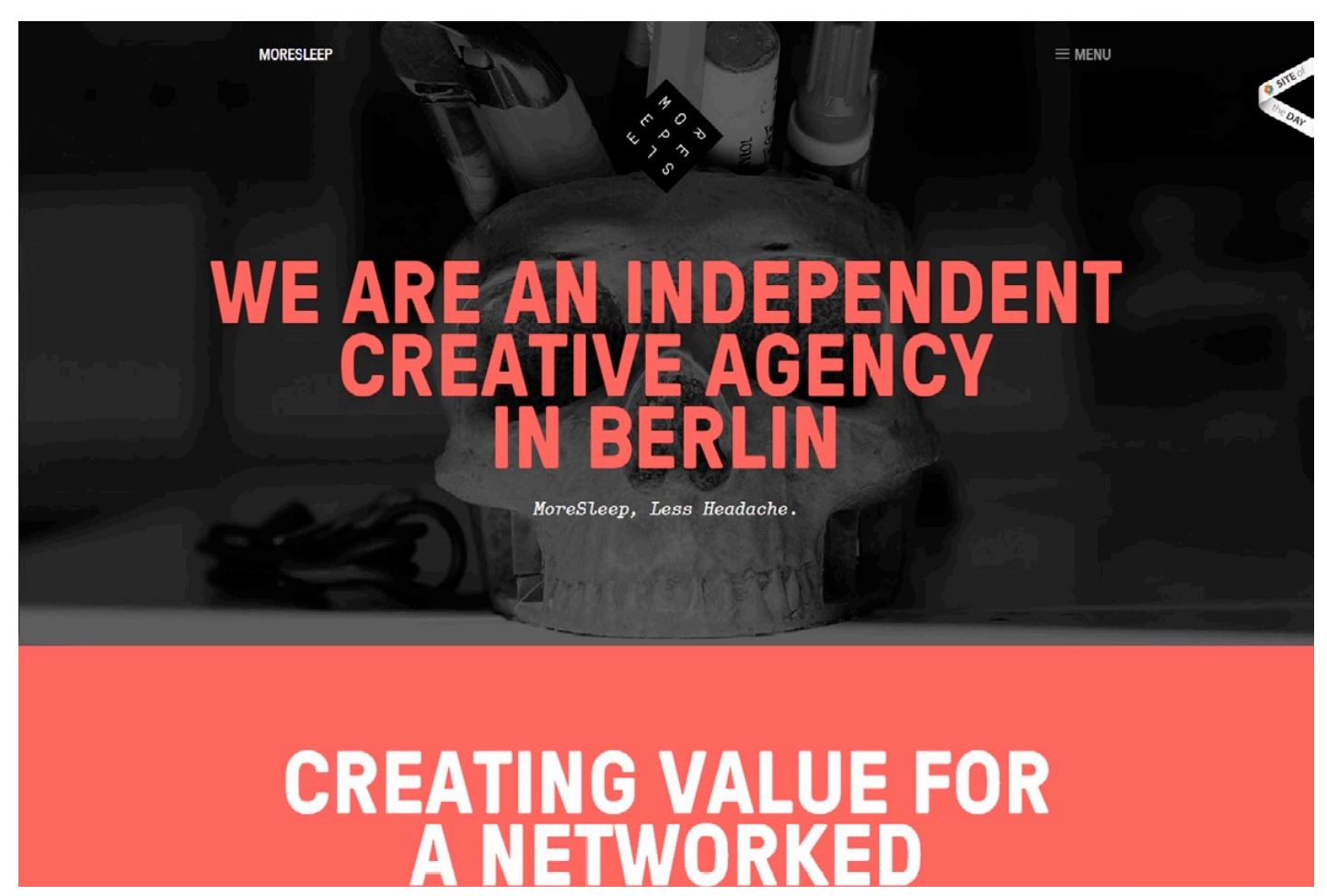

Слика 50 - Пример за ефект на паралакса

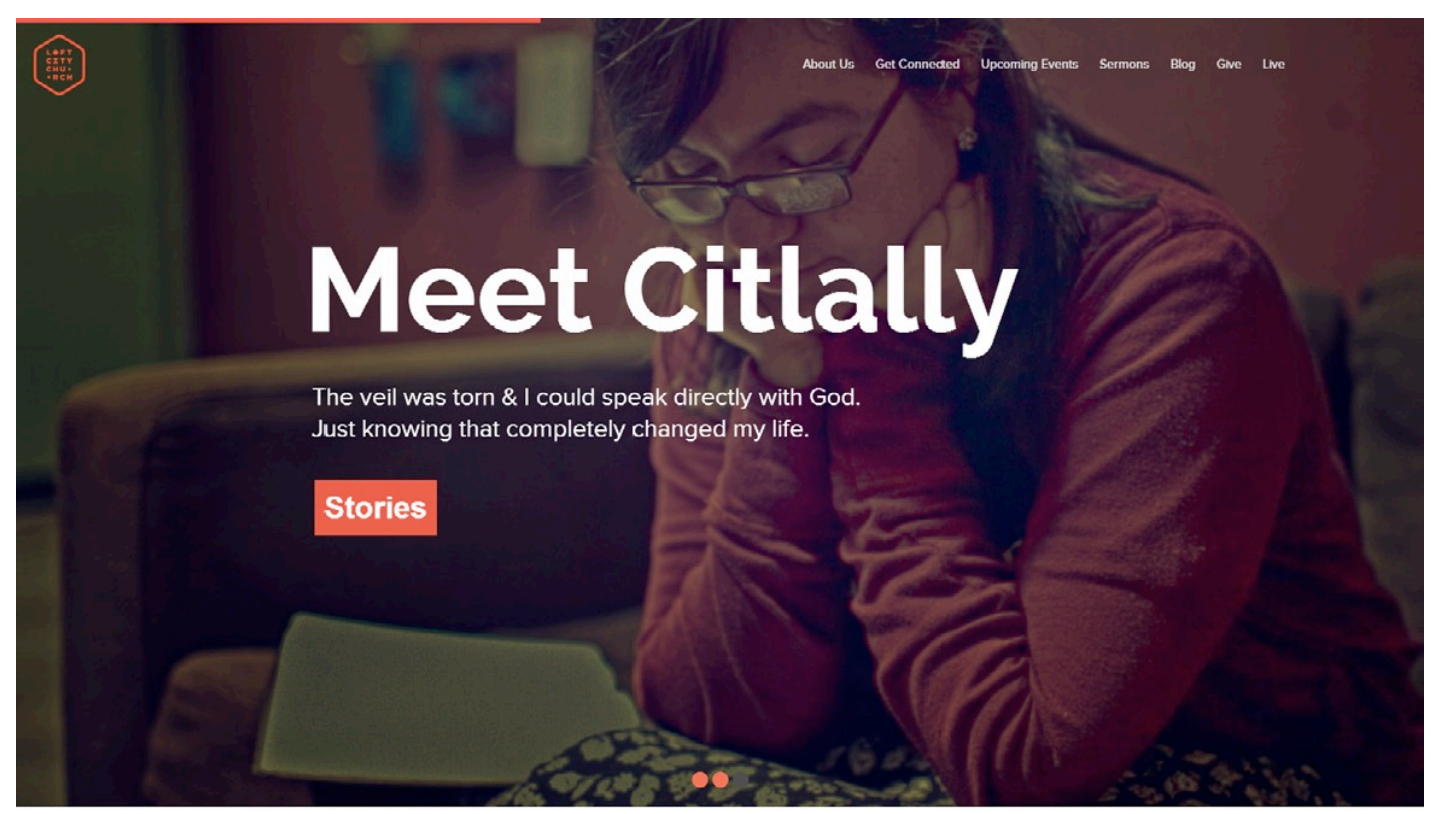

Latest Blogs

Слика 51 - Пример за ефект на паралакса 


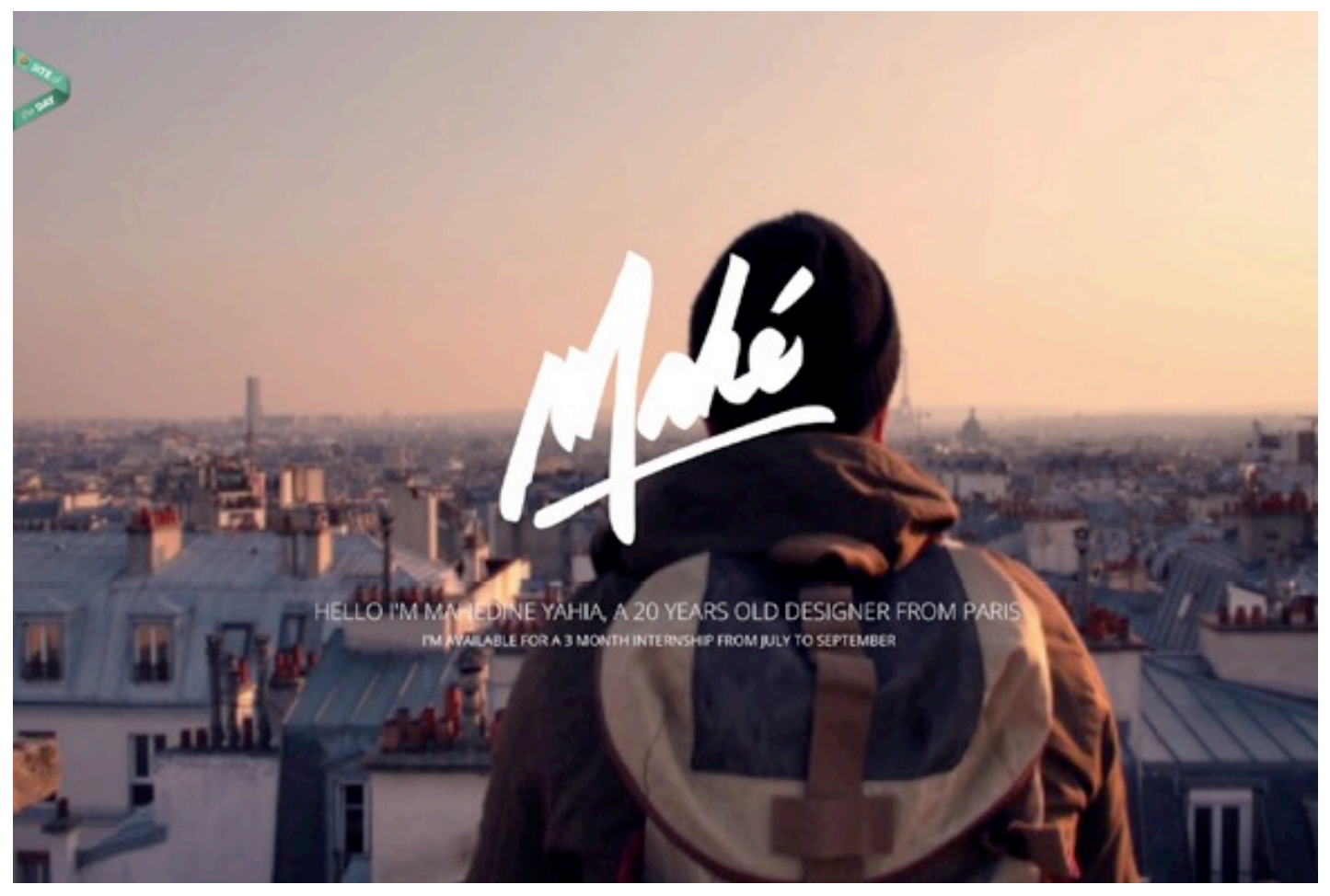

Слика 52 - Пример за ефект на паралакса

Појавата на HTML5 овозможи многу лесно креативно да се употребува мултимедија на веб страниците. Во 2013 година, тоа најде особено популарна примена кај позадината - искористување на видео материјал со висока резолуција како позадина. Видео позадината комплетно го промени визуелниот изглед и додаде динамичност на целото искуство. Меѓутоа, примената на видео позадина е оправдана на одредени веб локации кои се фокусираат да пренесат одредена приказна, а не на деловни веб локации или веб локации за Интернет продажба. Целта на видео позадината е двојна: потпомагање во процесот на привлекување на вниманието на корисникот и создавање незаборавна, емотивна, порака. 


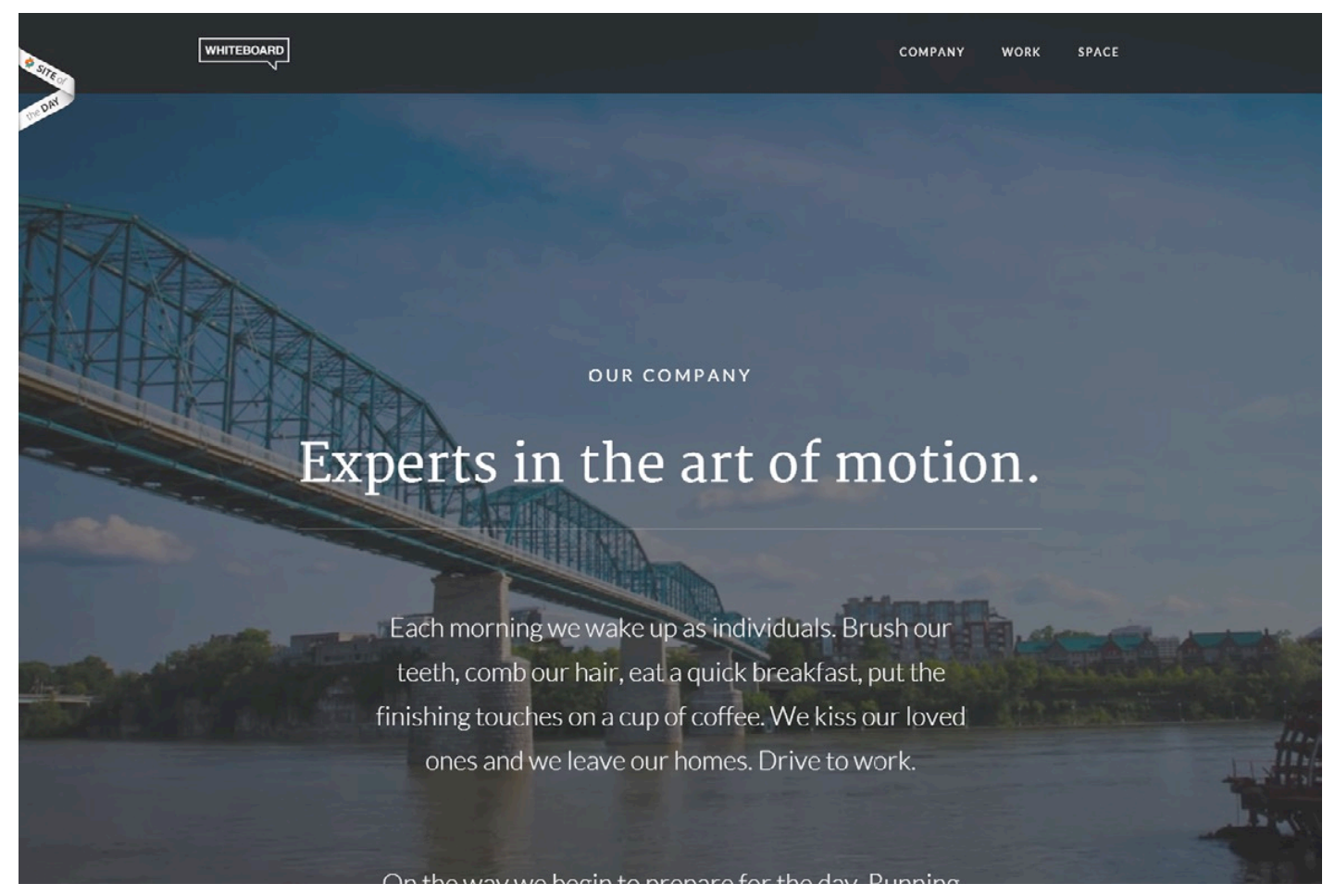

\section{Слика 53 - Пример за видео позадина}

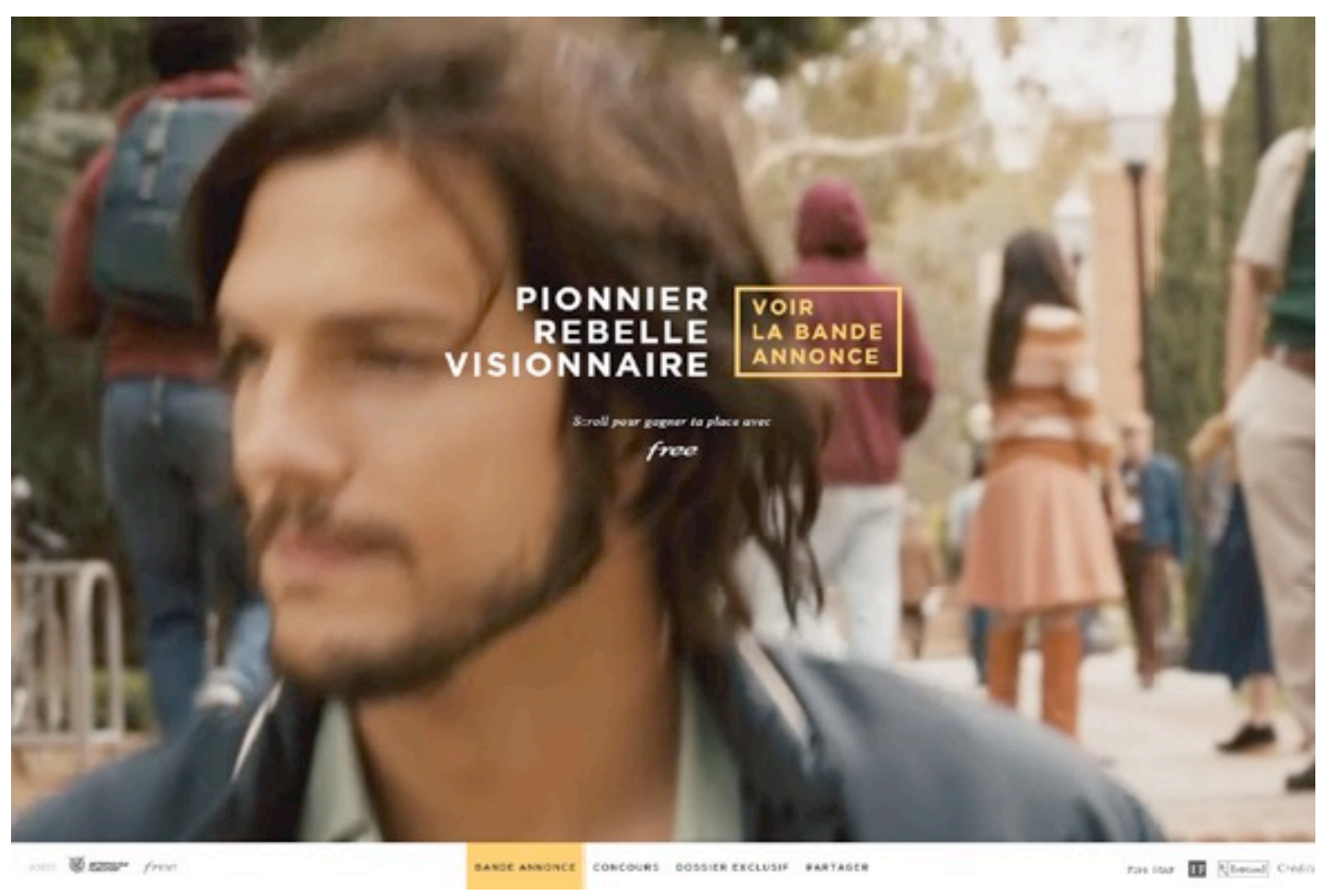

Слика 54 - Пример за видео позадина 


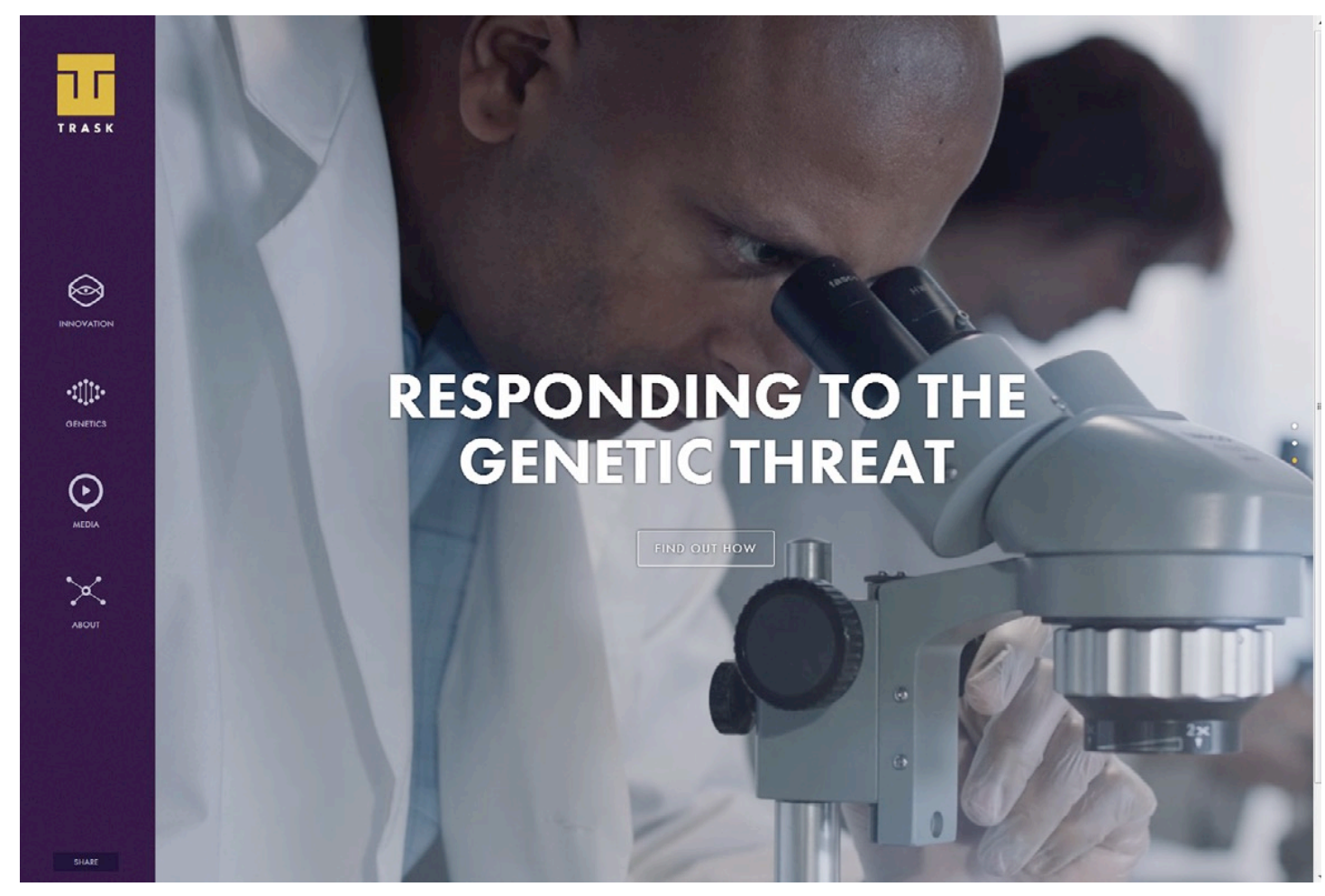

Слика 55 - Пример за видео позадина

Навигацијата како елемент е помеѓу најважните делови на секоја веб локација. Ниедна содржина нема да биде достапна без соодветно дизајнирана навигација. Од минатото научени сме да ја гледаме навигацијата поставена во горниот дел на страницата, лево или десно. Меѓутоа, во последно време дизајнерите започнаа да го менуваат овој концепт и да создаваат доста креативни решенија. Некои од нив се корисни (пр. навигација поставена во долниот дел на страницата), но некои не се толку корисни (пр. употреба на копчиња на тастатурата за да се оствари движењето). Во секој случај, ова е интересен и популарен тренд кој го менува изгледот на Интернетот.

Фиксирањето на позицијата на делот за навигација не е нешто ново, но во комбинација со употребата на една единствена страница за една цела веб локација во последно време стана многу популарен тренд. Ова е доста корисна комбинација кога станува збор за прегледување од мобилни уреди. Освен тоа, дури и со додавањето минимални преодни ефекти на одредени елементи се добива динамичен впечаток. 


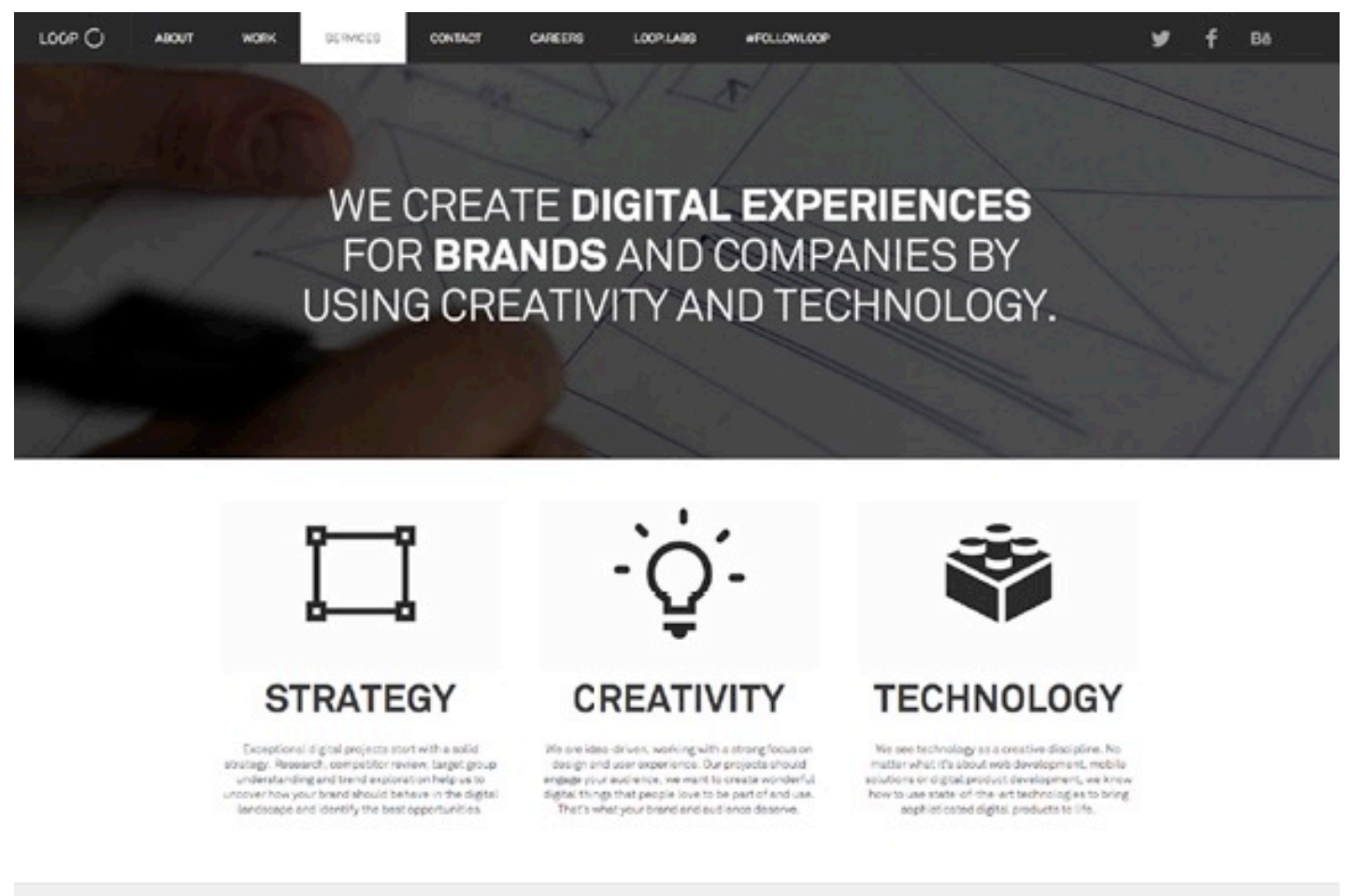

Слика 56 - Пример за фиксирана навигација
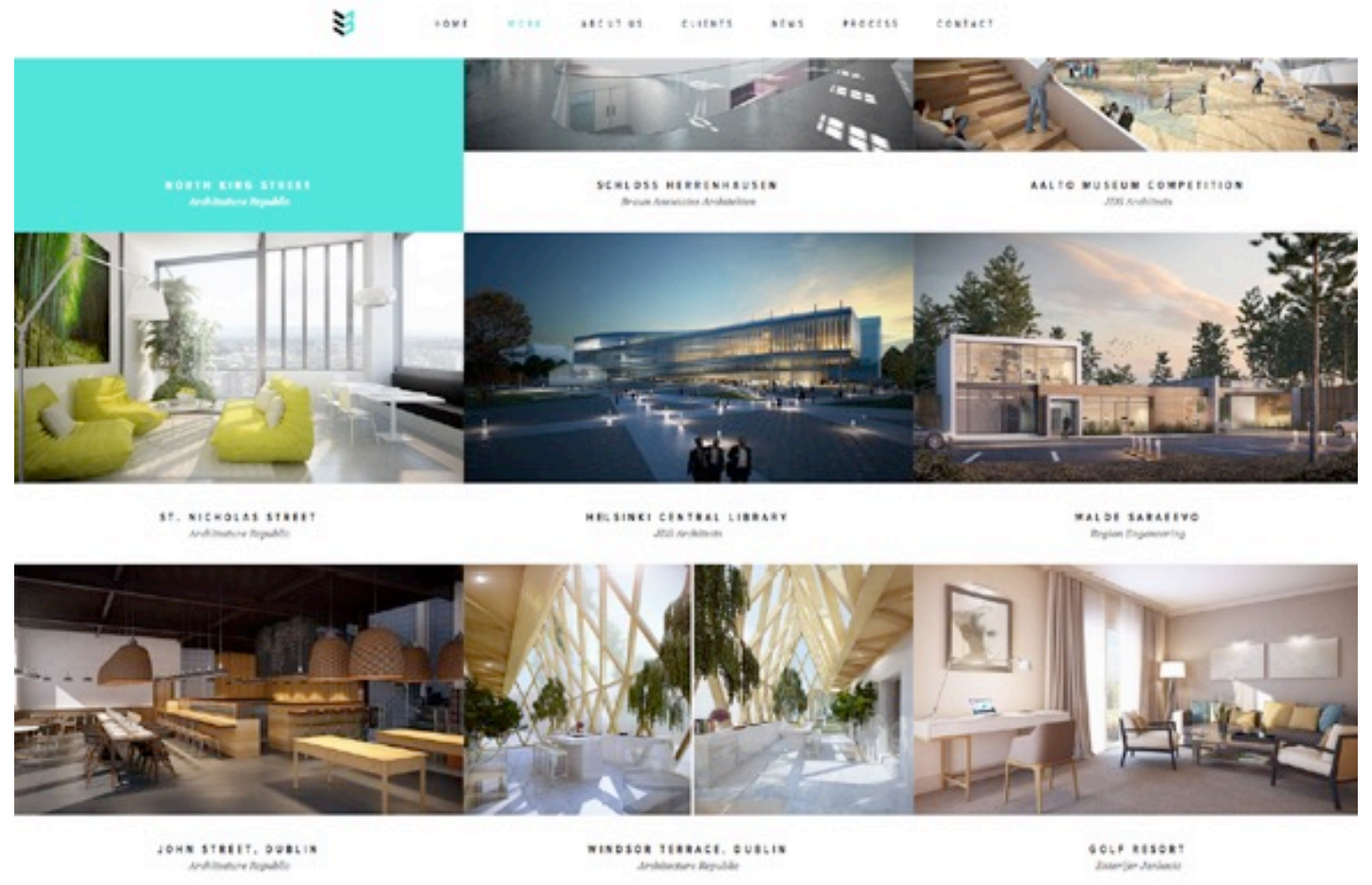

Слика 57- Пример за фиксирана навигација 
Рамниот дизајн е последниот тренд кој го освои дигиталниот свет. Да се каже дека рамниот дизајн е популарен не е ништо посебно. Рамниот дизајн буквално завладеа со дизајнерскиот свет. Овој стил се карактеризира со елиминација на непотребните графички елементи кои немаат никаква значајна вредност или цел во еден кориснички интерфејс. Клучна е едноставноста, декоративните елементи како градиенти, текстури и релјефи се избегнуваат. Стилот користи отворен простор, светли бои, остри рабови и дводимензионални илустрации со силен фокус на употребливоста. Со изоставувањето на сложената графика корисниците може полесно да се концентрираат на содржината. Microsoft најпрво го употреби овој стил во својата верзија на оперативниот систем Windows 8, резултатот беше дизајн кој воедно беше лесен за гледање и едноставен за навигација. Потоа, Google и Apple го адаптираа рамниот дизајн до некој степен и илјадници дизајнери го следеа тој чекор. Извесно е дека рамниот дизајн ќе биде долго време присутен.

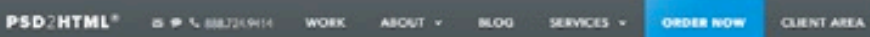

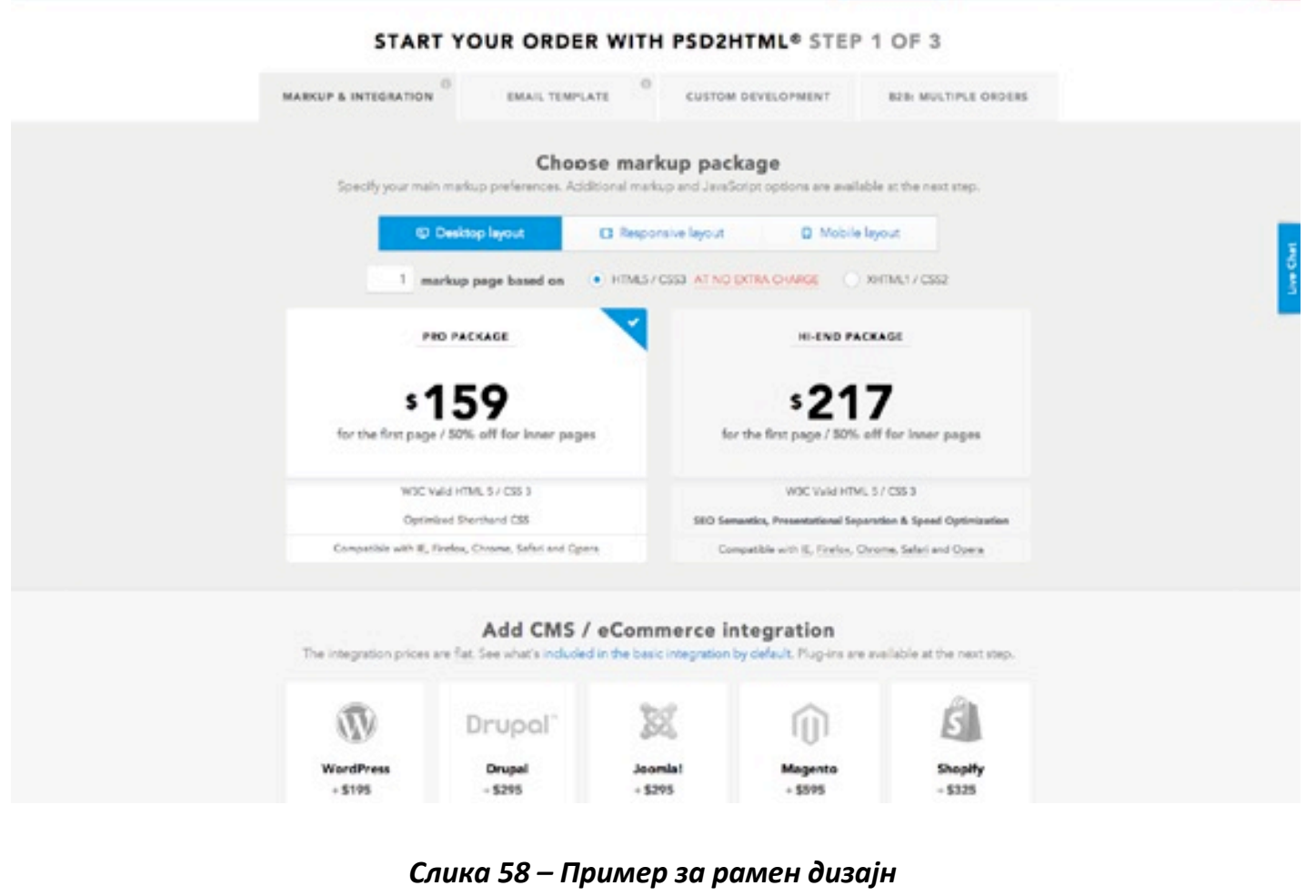




\section{TVLCORPs H으르}

DREAMS. DONE.

\section{Ler's begin $\rightarrow$}

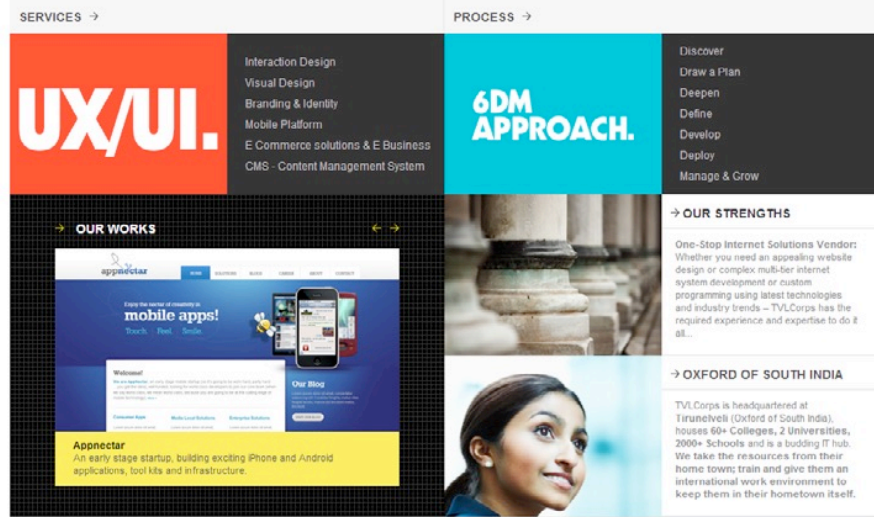

Слика 59 - Пример за рамен дизајн

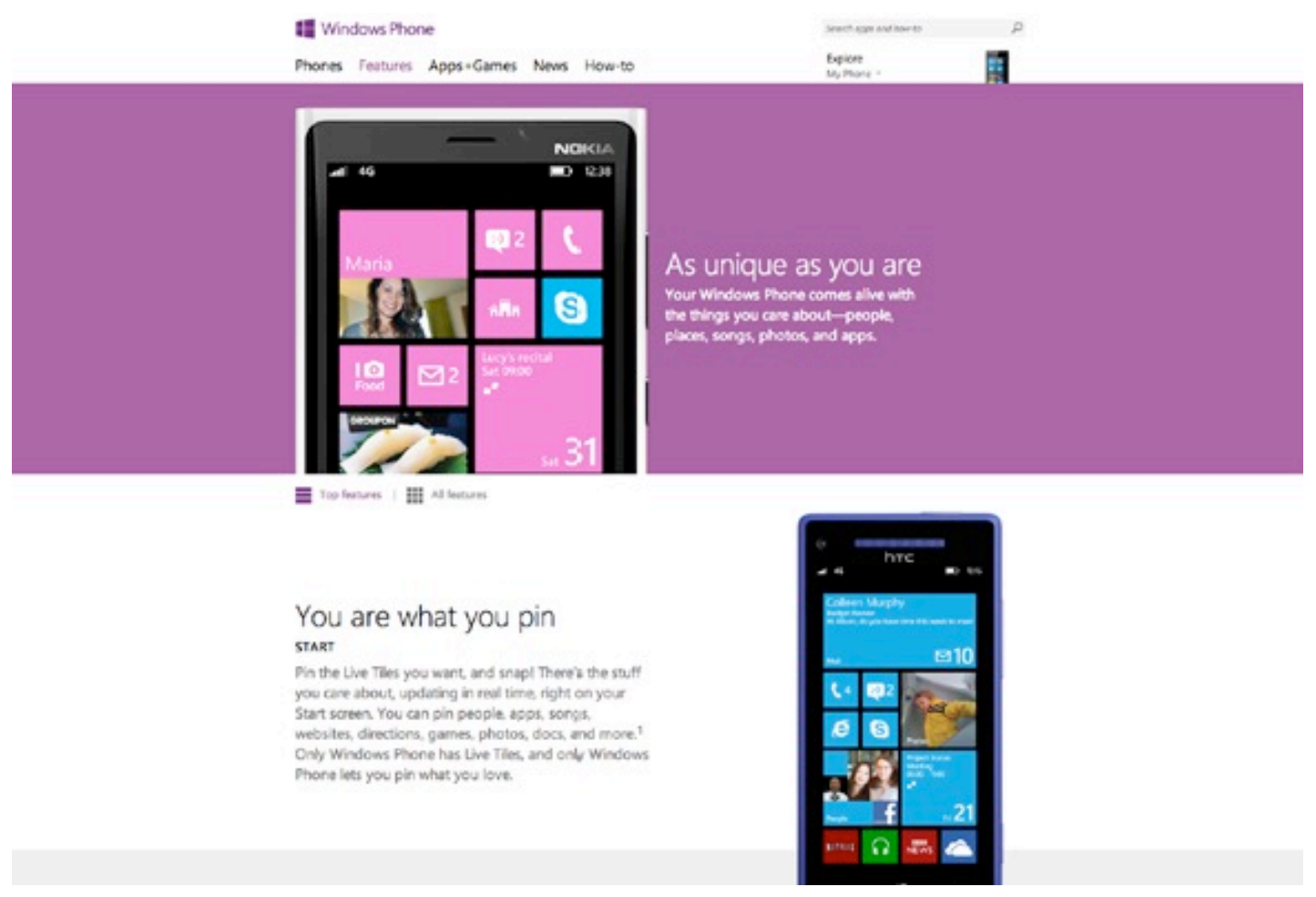

Слика 60- Пример за рамен дизајн 
Прилагодливиот дизајн ќе станува сѐ помоќен, а рамниот дизајн сѐ попопуларен. Значајна предност на рамниот дизајн е начинот како уникатно е адаптибилен од аспект на употребливост. Отфрлајќи ги непотребните стилизирања, времето на вчитување на страниците се многукратно намалено и самиот код на страниците е почист што значи дека веб локациите можат многу лесно да се прилагодат на повеќе платформи.

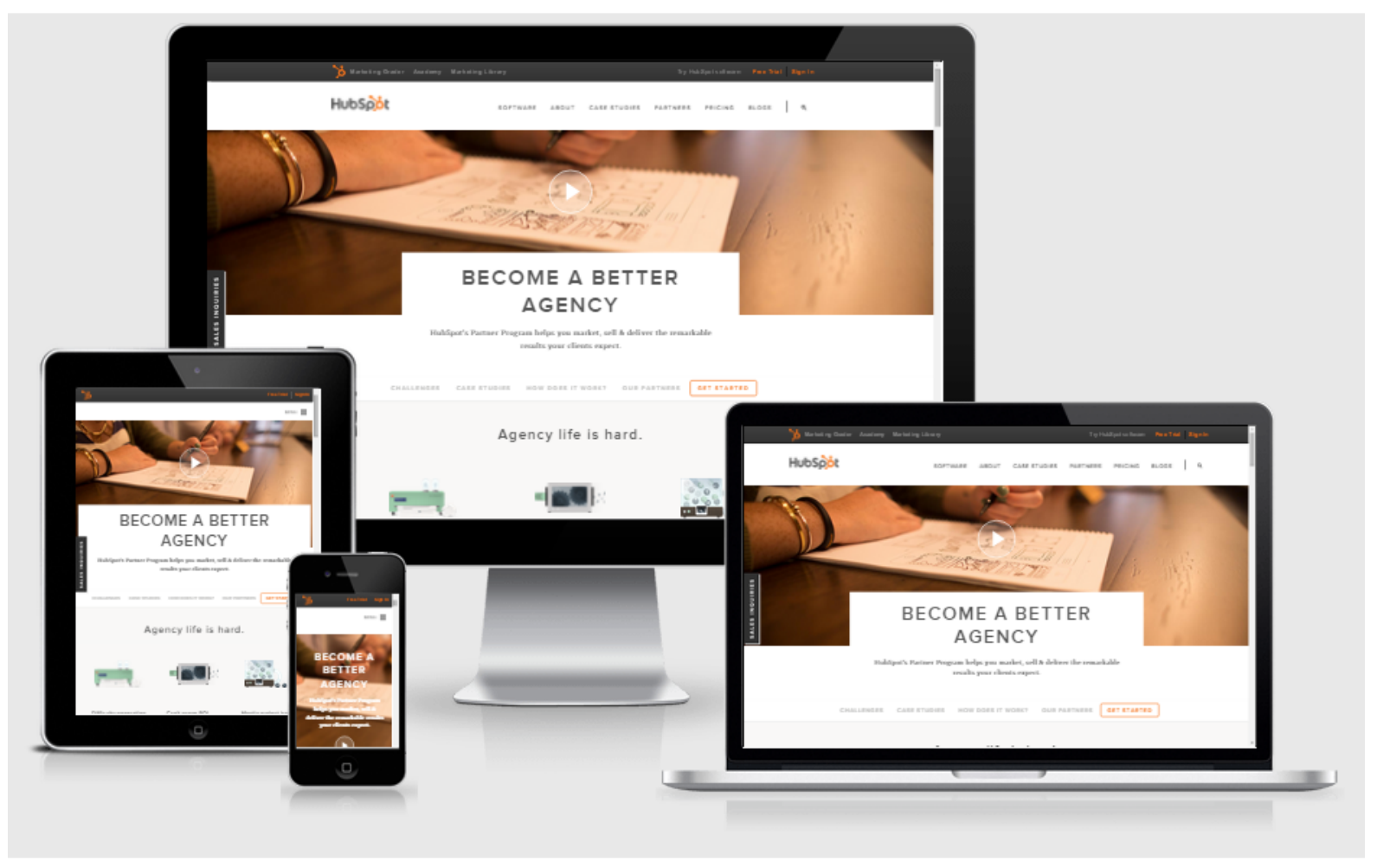

Слика 61 - Пример за прилагодлив веб дизајн 


\section{5. Анализа на конкурентски веб локации}

За да може подобро да се дизајнира една веб локација, освен исполнување на потребите на самите корисници, потребно е да се анализираат и конкурентските веб локации. Односно, како тие одговараат кон потребите на корисниците, да се забележат нивните предности како и нивните слабости. Од тоа истражување добро е да се извлечат позитивните елементи и ефикасно да се разрешат негативните, доколку се размислува на некакво нивно имплементирање во веб локацијата која се дизајнира.

Бидејќи во Република Македонија Центарот за истражувања, развој и континуирано образование нема соодветна конкуренција на Интернет просторот, а самото присуство не подразбира територијални ограничувања, како конкуренција ќе се разгледуваат неколку веб локации на странски центри за трансфер на технологии.

Прв е Центарот за истражување и развој во доживотното образование на Универзитетот Волверхамптон ${ }^{51}$ од Велика Британија (CRADLE - Centre for Research and Development in Lifelong Education - University of Wolverhampton). Важно е на самиот почеток да се спомене дека оваа веб локација е една од ретките која е изработена со прилагодлив веб дизајн и е погодна за прегледување од повеќе различни уреди. Со самото тоа има многу голема предност пред останатите конкуренти. Веднаш при пристапувањето на веб локацијата може да се забележи доста модерен дизајн кој комплетно соодветствува по обоеноста и распоредот на елементите (особено во горниот и долниот дел на страницата) со веб локацијата на самиот универзитет. На овој начин одлично е задржан идентитетот и несомнено е прикажана припадноста кон универзитетот. Самиот избор на бои асоцира на сталоженост и професионалност, како што впрочем и се бара од една веб локација од ваков тип. Во однос на распоредот тој е конзистентен на сите страници од оваа локација, а текстот е лесно впечатлив и разбирлив. Што се однесува до навигацијата, оваа веб локација има фиксна навигација во горниот дел што е совршено кога е потребно да се прегледува од мобилни уреди, бидејќи е намалена потребата од движење по страницата за да се премине на некоја друга. Освен тоа на десктоп верзиите на веб локацијата од левата страна на секоја

\footnotetext{
${ }^{51} \mathrm{http} / / / \mathrm{www} . w \mathrm{lv} . \mathrm{ac} . u k /$ research/research-institutes-and-centres/cradle---centre-for-research-anddevelopment-in-lifelong-education/
} 
страница може јасно да се забележи на кое ниво од веб локацијата се наоѓа корисникот и преку брз пристап да оди понатаму или да се врати назад. Разликата помеѓу верзиите може да се забележи преку компактното мени и помалиот број на колони - кај таблет верзијата има две, а кај мобилната верзија има една наместо четири колони, следствено страниците стануваат подолги на овие уреди.

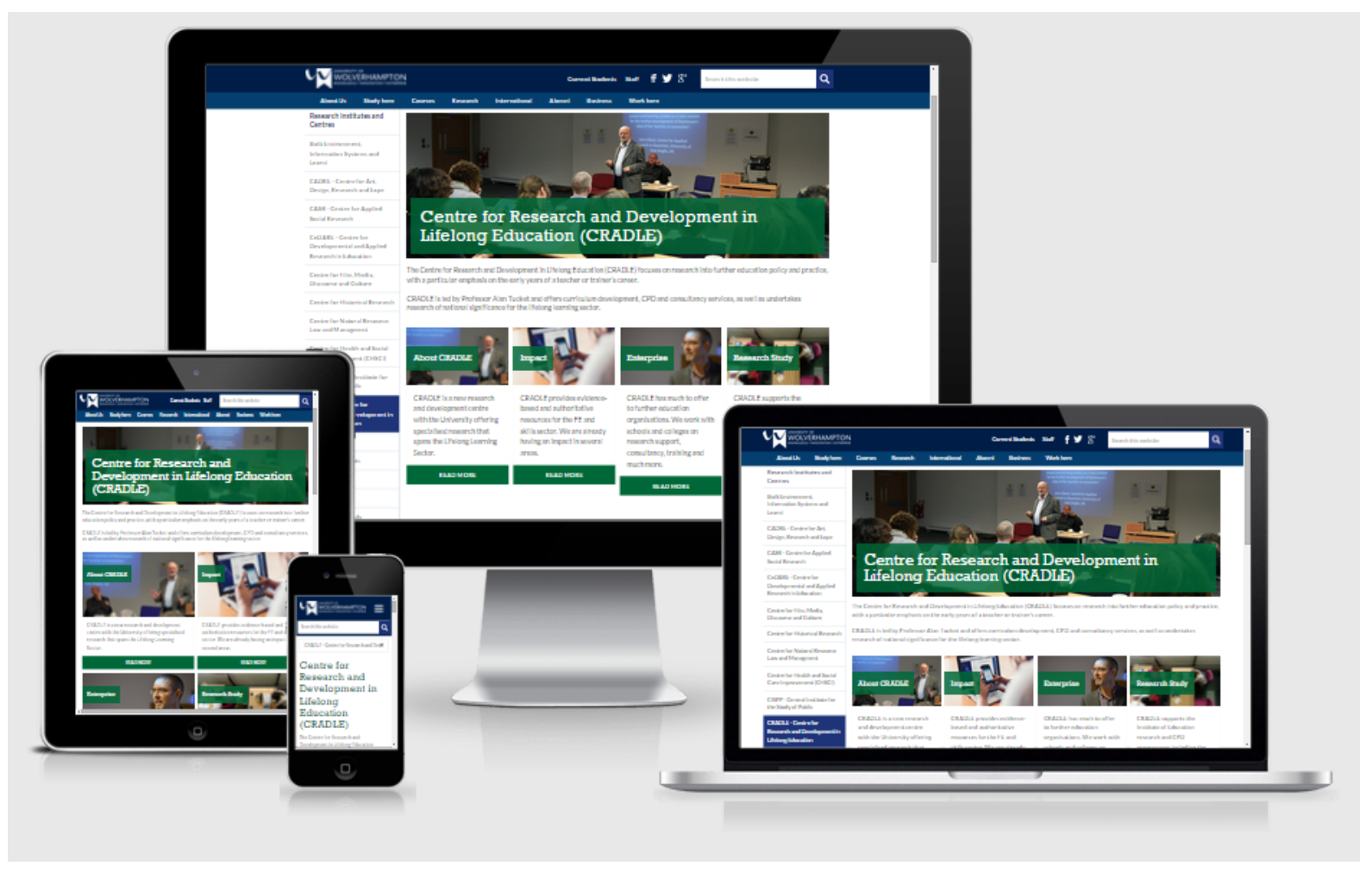

Слика 62 - Веб локација на CRADLE

Следна е веб локацијата на Центарот за трансфер на технологии на Политехничкиот универзитет на Каталуња ${ }^{52}$ (Centre de Transferència de Tecnologia de la Universitat Politècnica de Catalunya). Графички оваа веб локација го привлекува вниманието на посетителот, но освен што не е погодна за прегледување од мобилни уреди, целата веб локација е создадена со застарен начин на кодирање - со помош на табели. Со изборот на бои делува малку поразиграно одошто треба, а во споредба со изгледот на веб локацијата на самиот универзитет на кој што припаѓa не може да се каже дека има некаква поврзаност и веднаш може да се заклучи дека станува збор за нешто засебно

\footnotetext{
52 http://www.ctt.upc.edu/CTT_1_en.html
} 
и покрај сѐ. Кога станува збор за навигацијата, може слободно да се каже дека навигацијата на оваа веб локација не е баш добро осмислена во поставувањето. Најпрво таа е поделена на два дела, главната навигација преку која се пристапува до клучните страници е сместена во горниот дел непосредно до една огромна слика што делува како да е дел од сликата повеќе отколку на навигациски елемент. Споредната навигација од која се стигнува до подстраниците, се наоѓа од левата страна во елемент веднаш под горниот дел. Затоа што оваа навигација не е истакната на некој начин при првото пристапување се добива впечаток дека целата веб локација е создадена од само 5 страници, а не од повеќе како што навистина е. Во однос на содржината можам да кажам дека на целата веб локација истата е уредно прикажана. Меѓутоа, најголем впечаток од целата веб локација ми остави веб страницата за услугите. Имено, бидејќ јака страна на веб локацијата е графиката, дизајнерите имаат создадено одличен графички приказ за корисниците преку кој тие можат непосредно и едноставно да го разберат процесот на извршување на услугите.

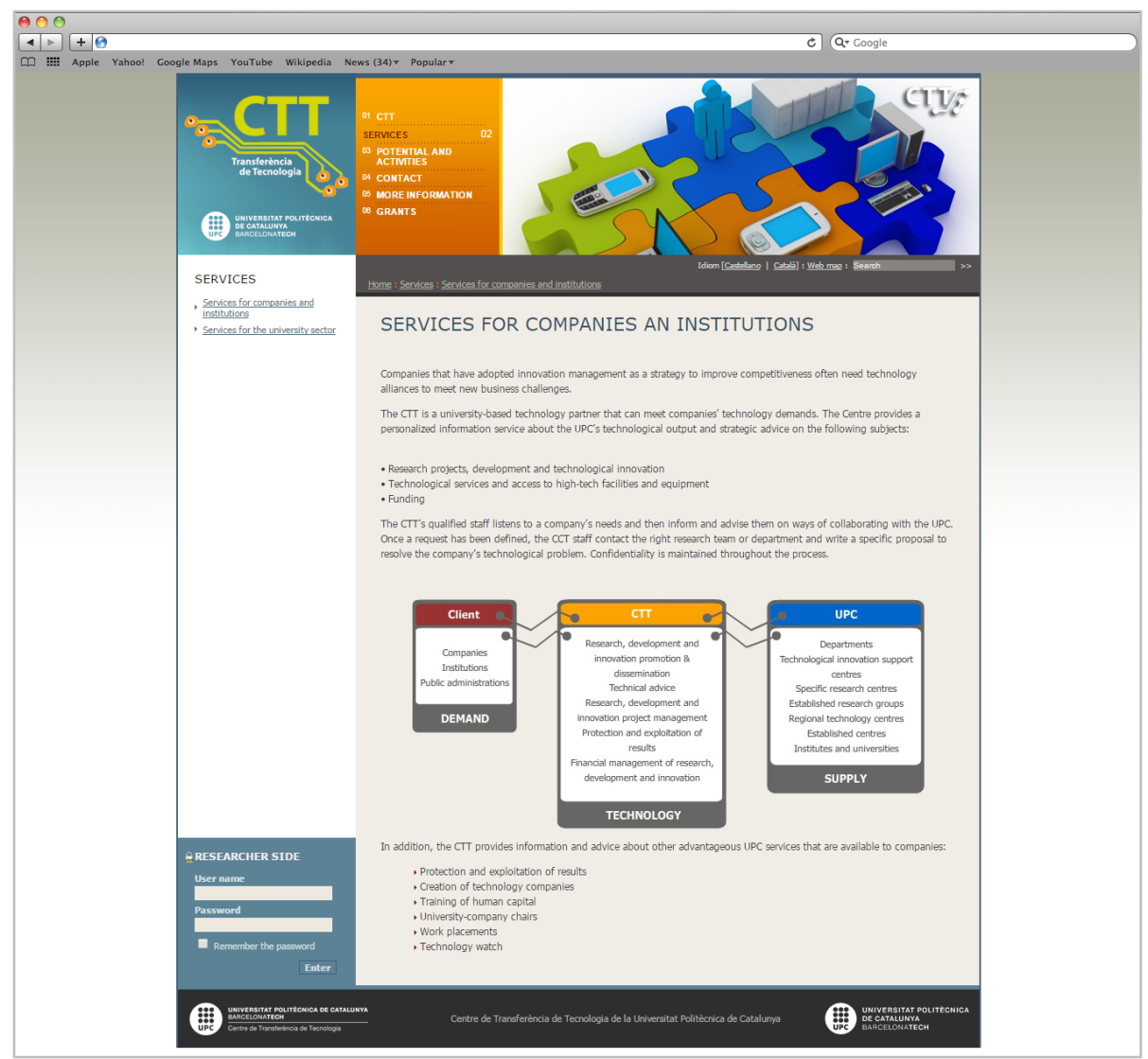

Слика 63 - Веб локација на CTT-UPC 
Останатите веб локации кои ќе бидат разгледувани се од САД. Прва од нив е веб локацијата на Центарот за трансфер на технологии на Масачусетс ${ }^{53}$ (The Massachusetts Technology Transfer Center). Повторно станува збор за една од ретките веб локации која е изработена со прилагодлив веб дизајн. Но, иако е предност прилагодливиот веб дизајн, оваа веб локација е доминирана од текст и малку слики од кои може да се забележи активноста на центарот поставени само на почетната страница. Следствено заради тоа и заради изборот на боите, на изглед оваа веб локација делува доста бледо и сериозно. Според мене клучно нешто што недостасува е токму поткрепувањето на текстот со соодветни слики како би се променила перцепцијата за веб локацијата од сериозна кон попрофесионална во однос на сведоштва за успешното извршување на услугите. Во однос на распоредот на содржините станува збор за една доста прегледна веб локација, со одлична читливост на текстот. Исто така, главната навигација е јасно истакната на сите верзии на локацијата, а споредната навигација која е поставена на некои страници според мене е чудно поставена за западни народи бидејќи е сместена од десната страна и се забележува небаре на крај на прегледувањето. Единствено, нема копче за враќање на почетната страница, па корисникот се очекува самиот (заради минатите искуства) да заклучи дека до нејзе може да се пристапи преку предимензионираното лого поставено во горниот дел над навигацијата.

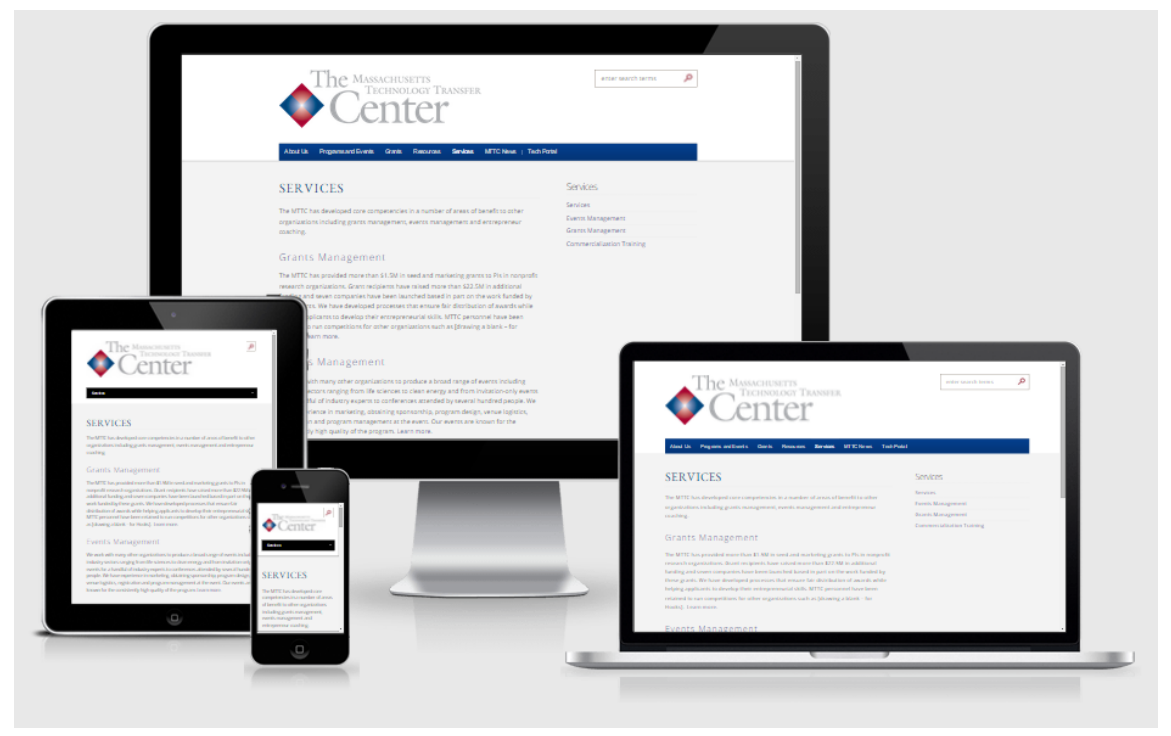

Слика 64 - Веб локација на МтTС

53 http://www.mttc.org/ 
Предпоследната веб страница која е од интерес е веб локацијата на Центарот за трансфер на технологии и создавање претпријатија на Универзитетот Карнеги Мелон (CTTEC - Center for Technology Transfer and Enterprise Creation - Carnegie Mellon University). Станува збор за релативно мала веб локација со чист, едноставен и информативен дизајн. Искористените бои се во комплетен склад со веб локацијата на универзитетот на кој припаѓa. Меѓутоа, оваа веб локација е далеку постаромодна од онаа на универзитетот која е со прилагодлив веб дизајн. Исто така, со намера е поставена во горниот лев агол, како што биле создавани старите веб локации, наместо да биде централно поставена на екранот. Сепак, распоредот на содржините е многу прецизен од кој се добива впечаток на висока професионалност и доследност.

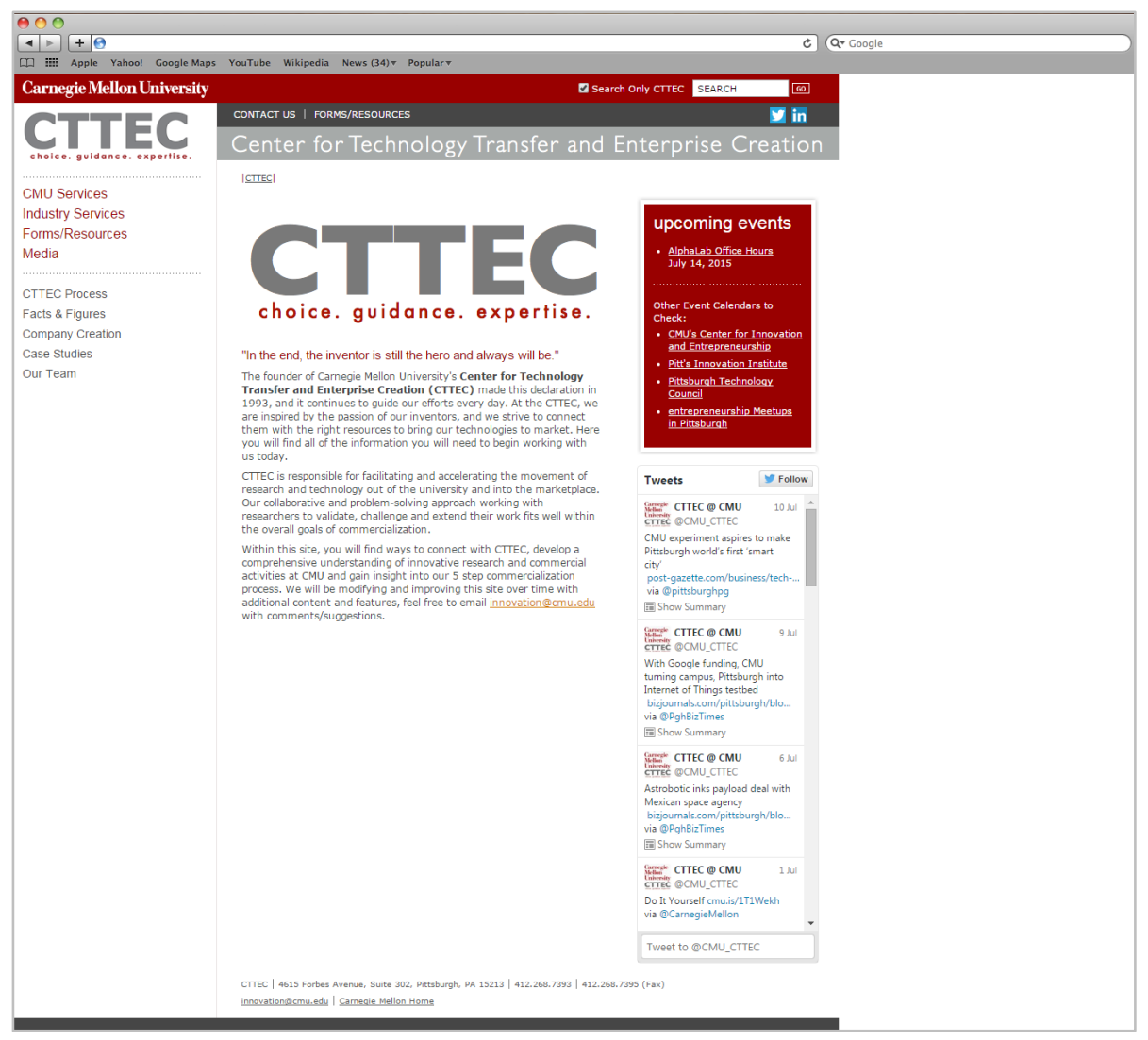

Слика 65 - Веб локација на СТTЕС 
Веб локацијата на State Farm центарот за истражување и развој на Универзитетот на Илинои ${ }^{54}$ (State Farm - Research and Development Center - University of Illinois) е последната веб локација која ќе биде разгледувана. Оваа веб локација не е изработена со прилагодлив веб дизајн, туку има посебна мобилна верзија која наликува повеќе на мобилна апликација за Apple уред. На прв поглед при пристапувањето на почетната страница делува многу сиромашно во однос на содржина. Нема многу големо присуство на бои, но затоа има изобилство мешани фонтови. Од дизајнерски аспект мислам дека оваа веб локација нема многу што да понуди, делува малку модерно, но кога ќе се разгледа подлабоко се добива впечаток како да не се оддало соодветно внимание на одржувањето на локацијата. Повторно далеку нескладна веб локација во споредба со веб локацијата на универзитетот на кој припаѓа, во однос на пристапот при создавањето и изгледот на самата локација.

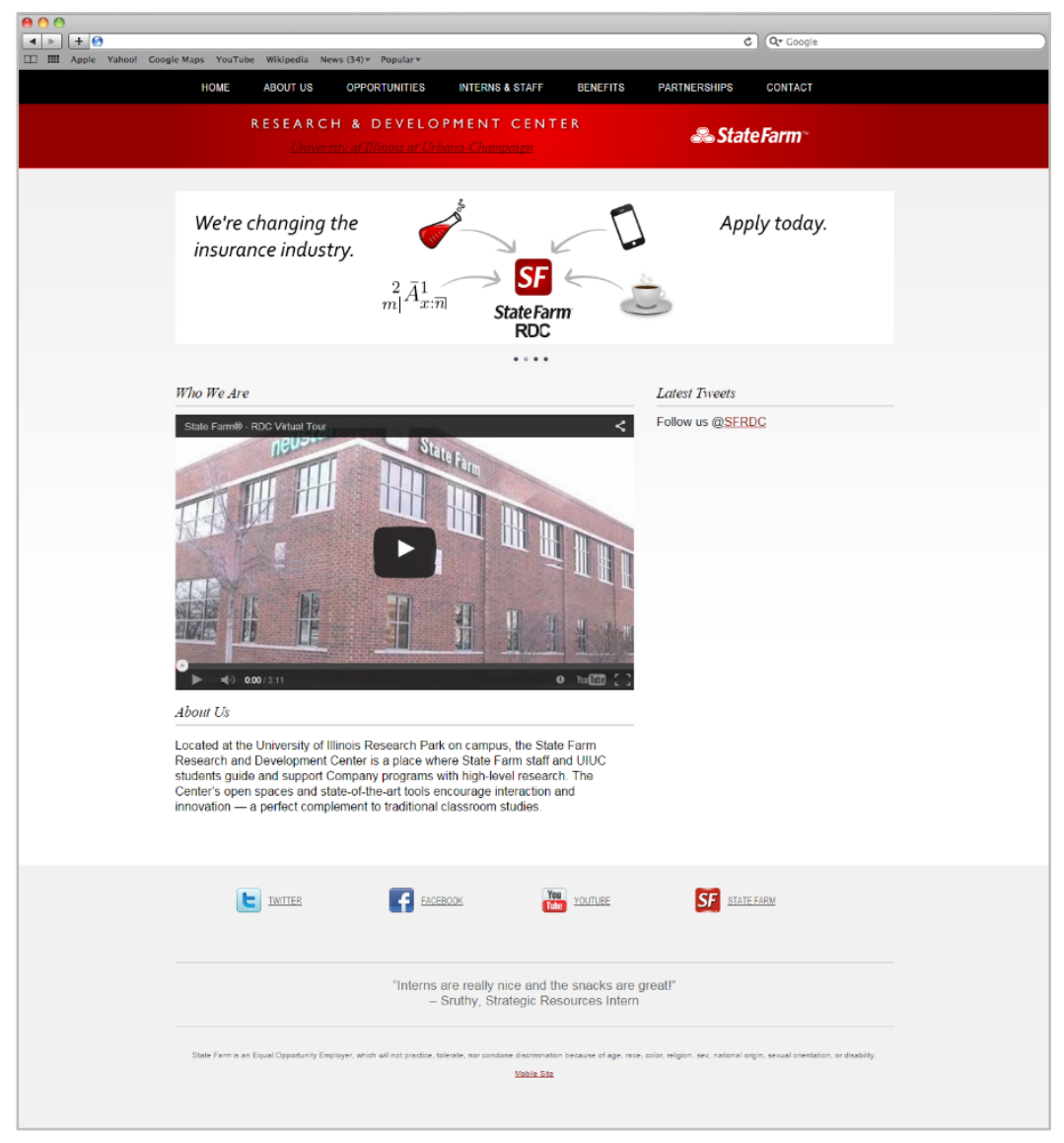

Слика 66 - Веб локација на StateFarm

\footnotetext{
${ }^{54}$ http://www.sfresearchcenter.com/
} 
Иако е во ред да има некаква разлика во однос на истакнувањето на центарот како засебна единка, сепак од сето ова може да се заклучи дека треба да се посветува внимание на одржувањето на веб локацијата и временото обновување на дизајнот за да се биде во тек како со актуелните трендови и можности (во однос на кодирањето), така и со стратегијата на универзитетот. Конечно, позитивните елементи на секоја разгледана веб локација ќе бидат земени предвид, а за негативните ќе се направи обид да се надминат или значително да се подобрат. 


\section{6. Дефинирање на конкретна задача - дизајн на веб локација и промотивен материјал за компанијата ЦИРКО ДООЕЛ Скопје}

Без разлика дали станува збор за физички или виртуелен производ, една дефиниција ${ }^{55}$ за дизајнот вели дека дизајнот е стратешки пристап за постигнување одредено уникатно очекување. Дизајнирањето вклучува решавање на одреден проблем и креативност. Притоа, потребно е да се размислува за естетските, функционалните, економските и социополитичките димензии на самиот производ кој се дизајнира.

Денес постојат илјадници веб локации на Интернет, следствено секоја се натпреварува за да го привлече вниманието на Интернет корисниците. Заради тоа, од исклучителна важност е првиот впечаток кој се добива кога ќе се пристапи на одредена веб локација. Во понатамошниот текст, претходно изложената теорија во оваа магистерска работа ќе биде опишана преку практичен пример - создавање модерна и препознатлива веб локација за компанијата ЦИРКО ДООЕЛ Скопје, богата со содржини што ќе обезбеди квалитетна презентација на сите сектори и дејности кои ги покрива оваа компанија, а со тоа да се подобри нејзината достапност, видливост и рејтинг на пазарот, но, не само во естетска, туку и во функционална смисла, со цел да се подобри корисничкото искуство.

Бидејќи веб локацијата на Центарот за истражувања, развој и континуирано образование на некој начин претставува портал од кој може да се пристапи до веб локациите на одделните негови сектори, целиот проект всушност започна од поодамна со редизајнирање на постоечките и со креирање на нови веб локации на секторите.

${ }^{55}$ Y. D. Kumaragamage, Design Manual, Vol.1, 2011. 


\section{1. Х Хронологија на развојот на веб содржините на ЦИРКО ДООЕЛ}

\subsection{1 Веб локација на секторот за индустриски дизајн}

Прелиминарна верзија на веб локацијата за секторот индустриски дизајн ${ }^{56}$ беше креирана од студент на насоката индустриски дизајн како негова дипломска работа во 2012 година. Но, за нејзино поставување на Интернет просторот беше неопходно потребно да се извршат одредени корекции. Дизајнот во голема мера беше задржан, но најголеми промени претрпе организацијата на содржините на веб локацијата на сервер страната. Откако сите елементи беа уредно сместени во соодветни папки, се продолжи со корекција и обнова на содржината:

- корекција на неправилно поврзаните врски помеѓу страниците

- промена на наслови, поднаслови, менија и сл. од графика во текст заради подобро понатамошно одржување/менување,

- поставување на комплетно ново посоодветно паѓачко мени заради директен пристап кон одделните услуги итн.

- додавање дополнителни графички содржини, како на пример галерија со слики на почетната и страниците на услугите, информациски карусел на почетната страница и слично.

Конечно, беше извршена оптимизација во однос на брзината на вчитување и обработка на страниците, со разделувањето на графиката поставена како позадина. Претходната верзија на веб локацијата, освен тоа што имаше посебна датотека со однапред зададени димензии на позадината, имаше и посебни датотеки за секоја страница, а на некои страници се повторуваа позадините. Со поделбата на графиката се овозможи независно зголемување на страниците без потреба од измена на датотеката со графиката на позадината, намалување на бројот на датотеки со позадини и општо намалување на големината на самата веб локација, што последователно подразбира олеснета понатамошна промена и подобрена одржливост на страниците.

\footnotetext{
${ }^{56}$ www.idealab.mf.edu.mk
} 


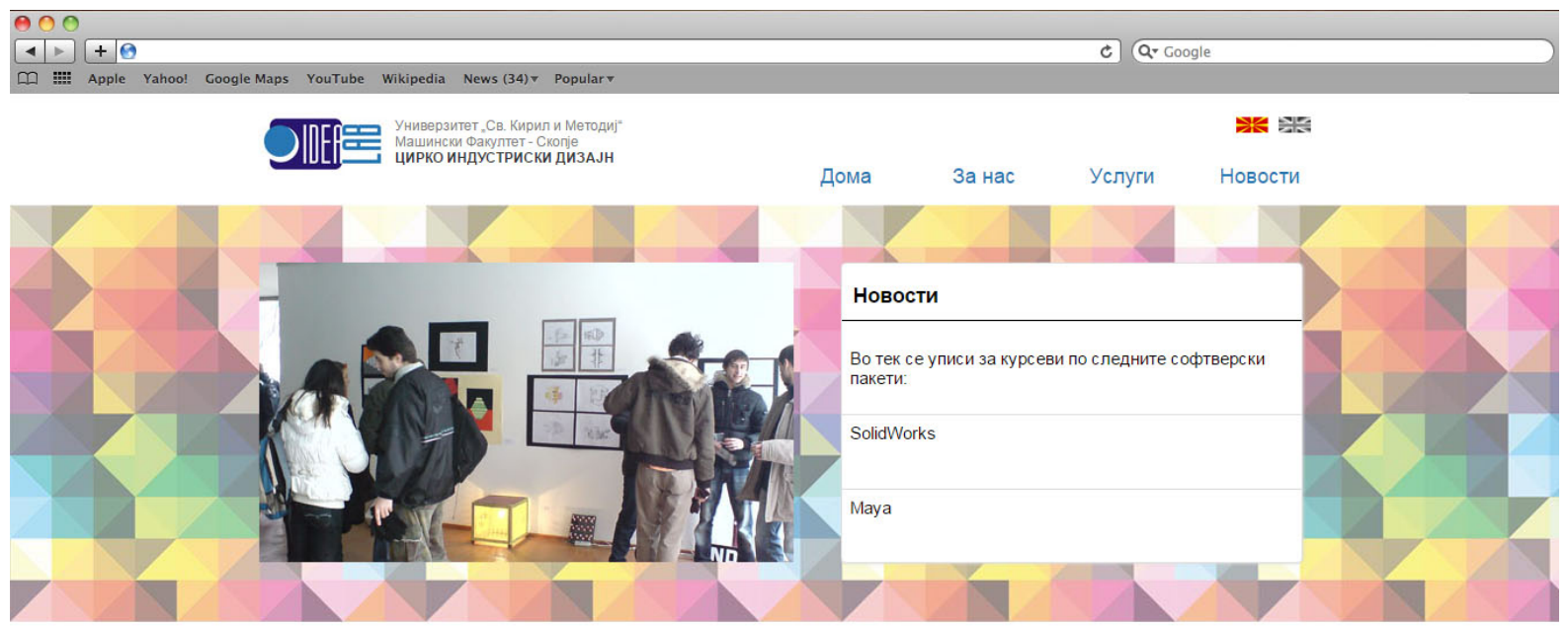

ЦИРКО - ИНДустРИСКИ ДИЗА.Н е услужна единица во рамките на Машинскиот факултет во Скопје. Со високостручен кадар, работилници, опрема

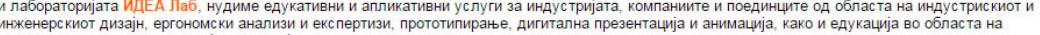
современи инженерски и дизајнерски софтвери.

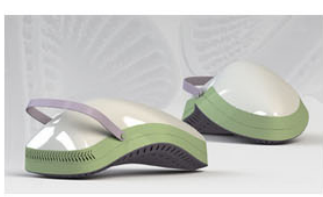

Индустриски дизајн

Нудиме услуги од областа на индустрискиот дизајн како, естетско обликување на производи, развој на концепти и сценарија ентериери производи по мерка на човекот, инспирирани
од природата, кои се грижат за природата. од природата, кои се грижат ја прирората.

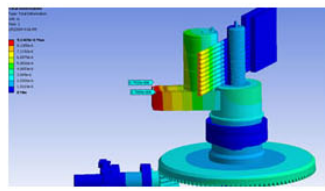

Инженерски дизајн Ако ви е потребна соработка во решавањето да ви помогнеме со обуки и експертиза сврзани за различни видови на инженетс анализи на дизајнерсиите

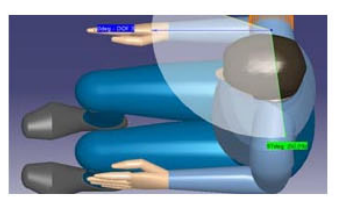

Ергономија

Услуги од областа на ергономијата и антропометријата во дизајнот на производи и ентериери: експертизи во дизајн на

аспект ни комфор, ефикасност, виртуелно тестирањ тестирање на комффо

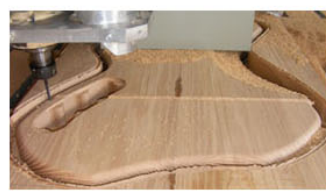

Прототипирање Ако имате потреба да ги преточите вашите дизајнерски идеи во физички модел, ви креирањето на прототипови, со цел да ви

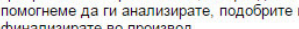

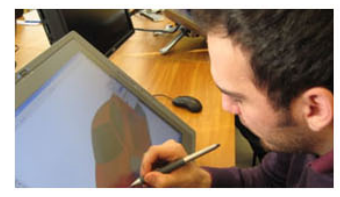

Едукација

Преку курсеви и школи ви нудиме рашите теоретскии, практични и компуутерс онципирањето на нови производи. па се да изработката на техничката документација

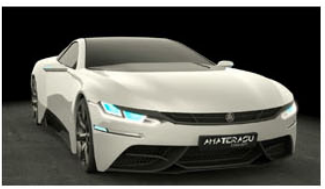

Дигитална презентација Визуелизација на производи и простори како слуга за архитекти, дизајнери, инженери сделирање и анимација со примена на современите софтверски алатки MAYA и 3D

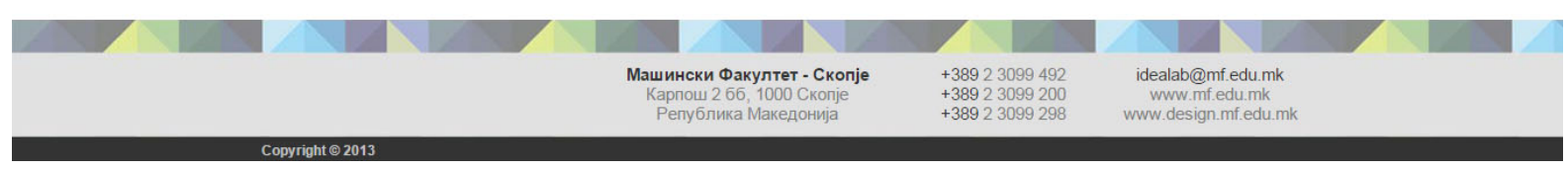

Слика 67 - Почетна веб страница на ЦИРКО-ИНД (челосен приказ) 


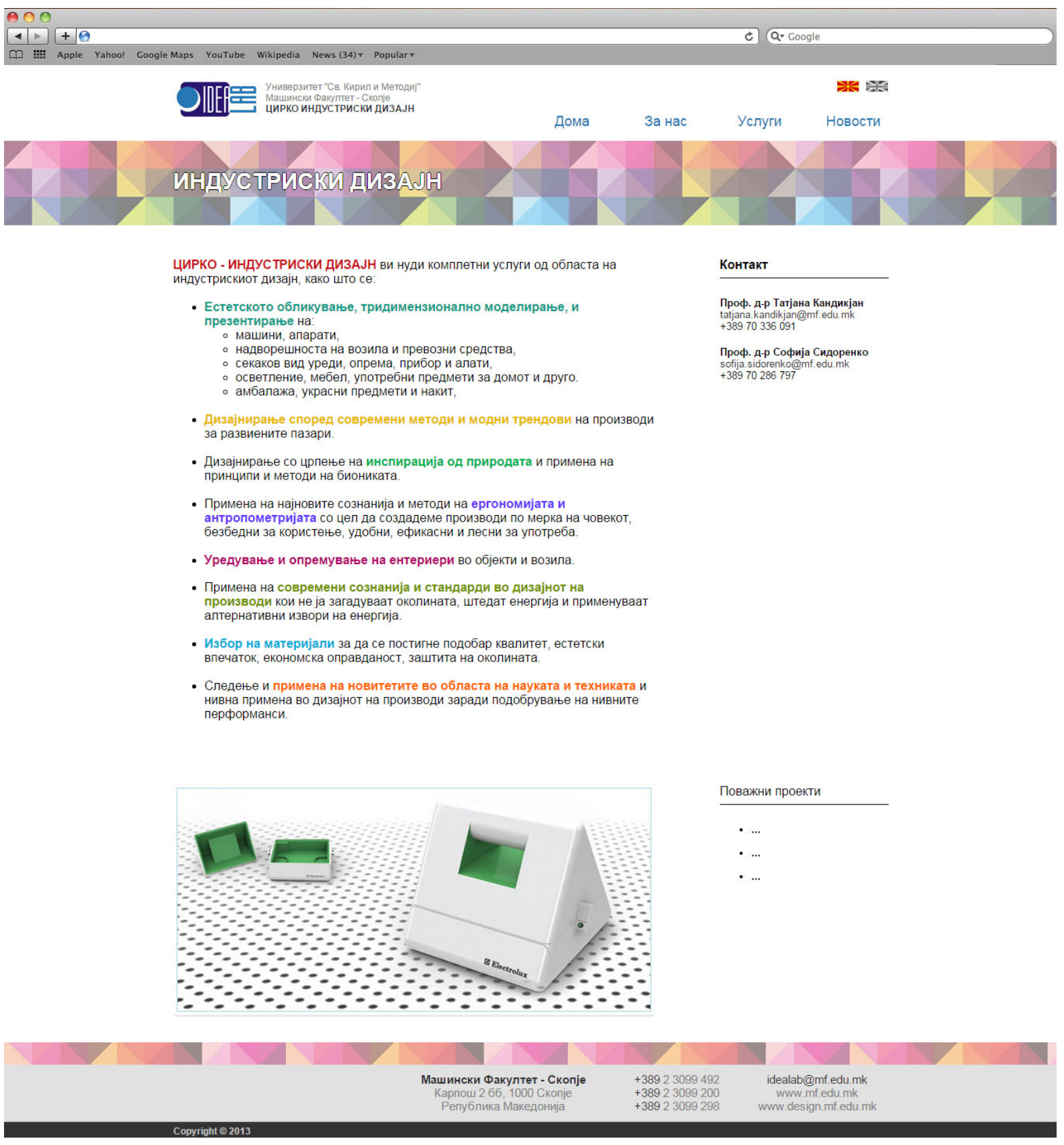

Слика 68 - Типска веб страница (,Индустриски дизајн“) на ЦИРКО-ИнД (целосен приказ) 


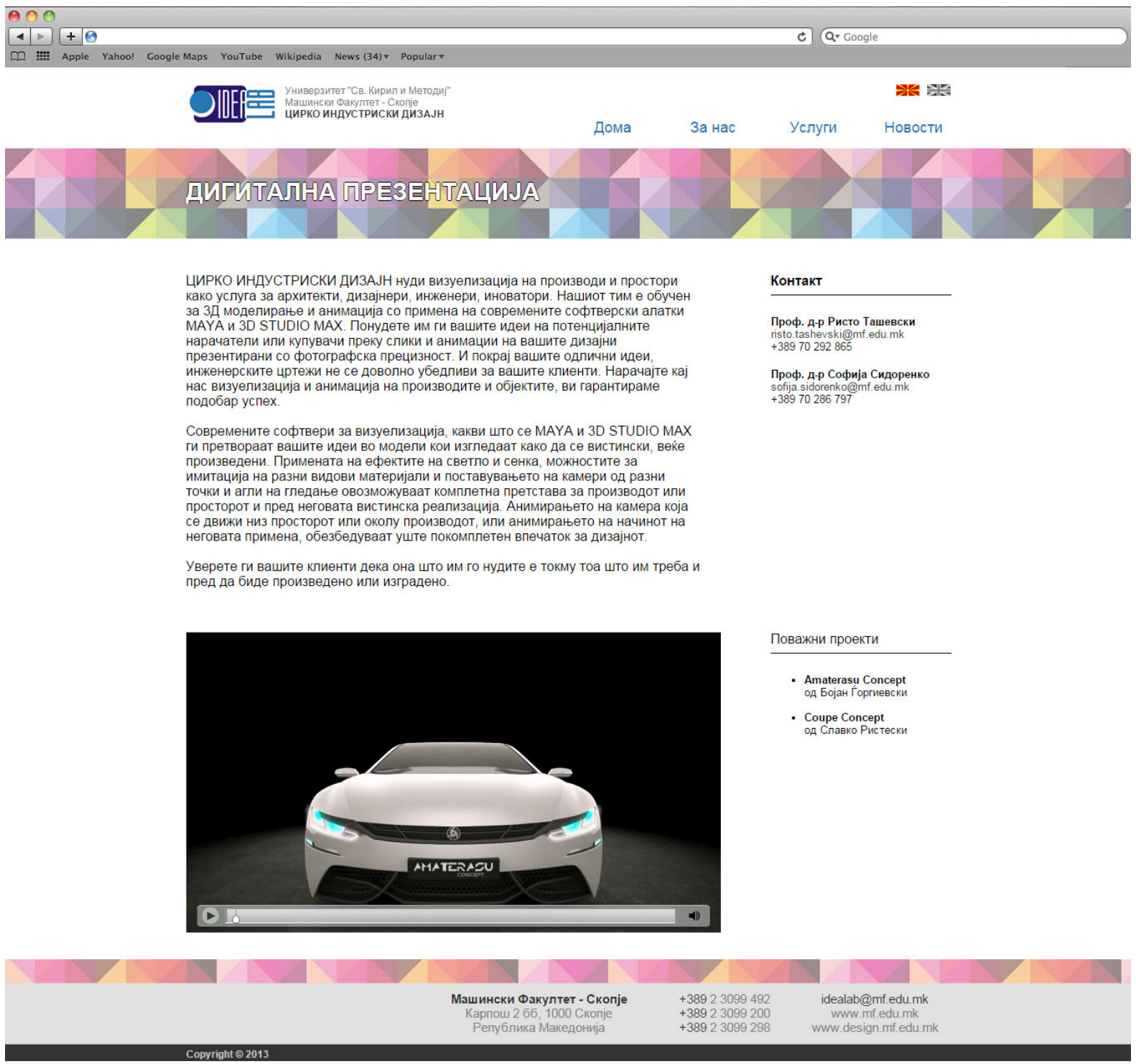

Слика 69 - Типска веб страница („Дигитална презентација“) на ЦиРКО-ИНД (целосен приказ) 


\subsection{2 Веб локација на лабораторијата за калибрација на сила и момент на сила}

Поради подобра структурираност на податоците и полесна манипулација со истите беше одлучено да се преработи и постоечката веб локација на лабораторијата за калибрација на сила и момент на сила ${ }^{57}$, која претходно беше изработена како дипломска работа од студентка на насоката индустриски дизајн. И во овој случај не настана драстичен редизајн на изгледот, туку најмногу на структурата на веб локацијата и на веб страниците кои ја сочинуваат. Меѓутоа, потребно беше одново да се постави целата веб локација, заради големиот број непотребни содржини кои беа оставени на сервер страната на веб локацијата. Откако беа извлечени и организирани потребните содржини, се премина на создавање на нови CSS датотеки со цел да се намали употребата на графички датотеки за копчињата, позадината и некои други елементи. Во новата веб локација употребата на графички датотеки е сведена на неопходниот минимум, а со тоа е многукратно намалено времето на вчитување на страниците од целата веб локација. Понатаму, беше додадена сосема нова галерија на почетната страница и функционална Google мапа на страницата за контакт (наместо само слика како што беше на претходната веб локација).

\footnotetext{
${ }^{57}$ www.callab.mf.edu.mk
} 


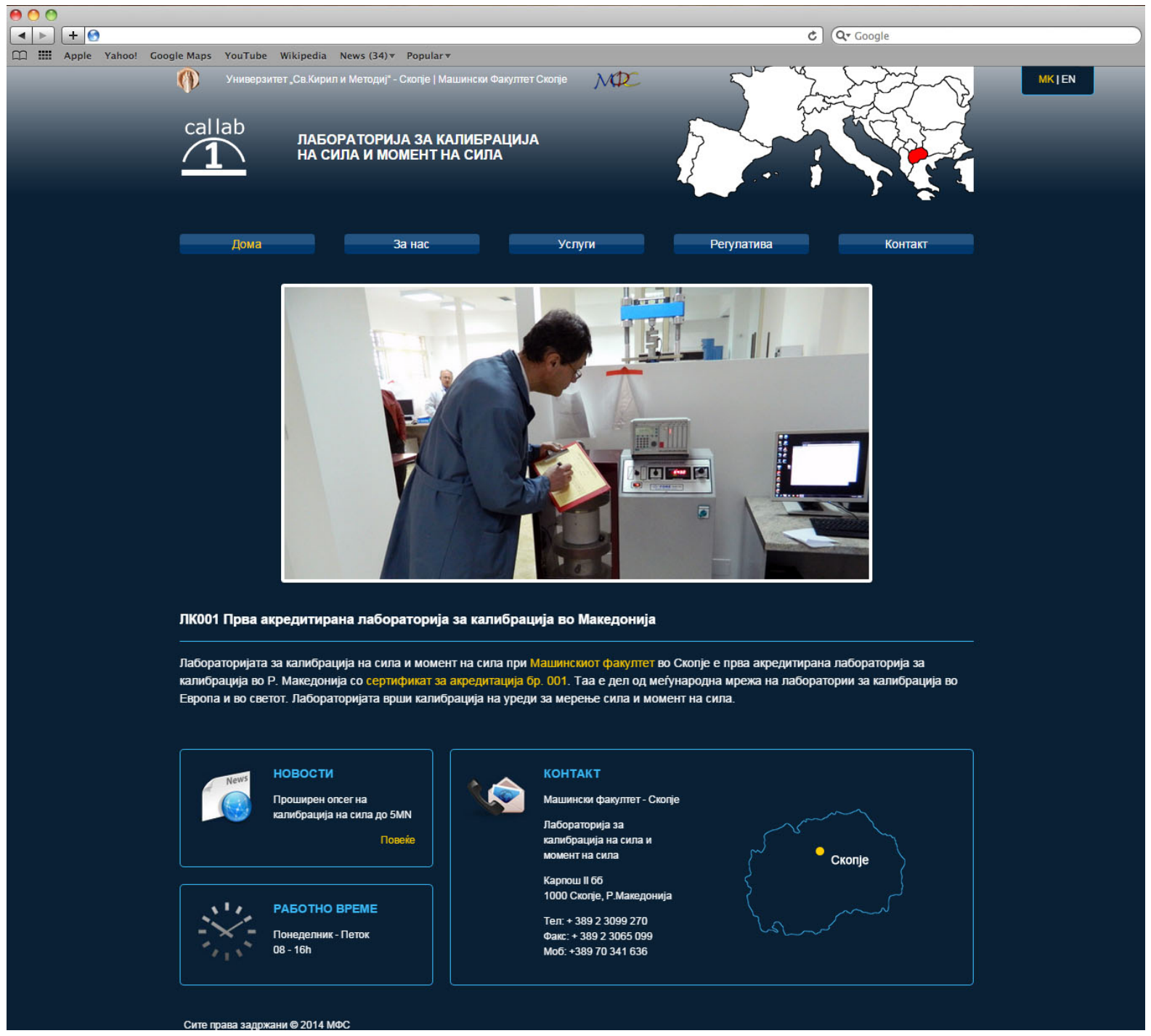

Слика 70 - Почетна веб страница на Лабораторијата за калибрација на сила и момент на сила (целосен приказ) 


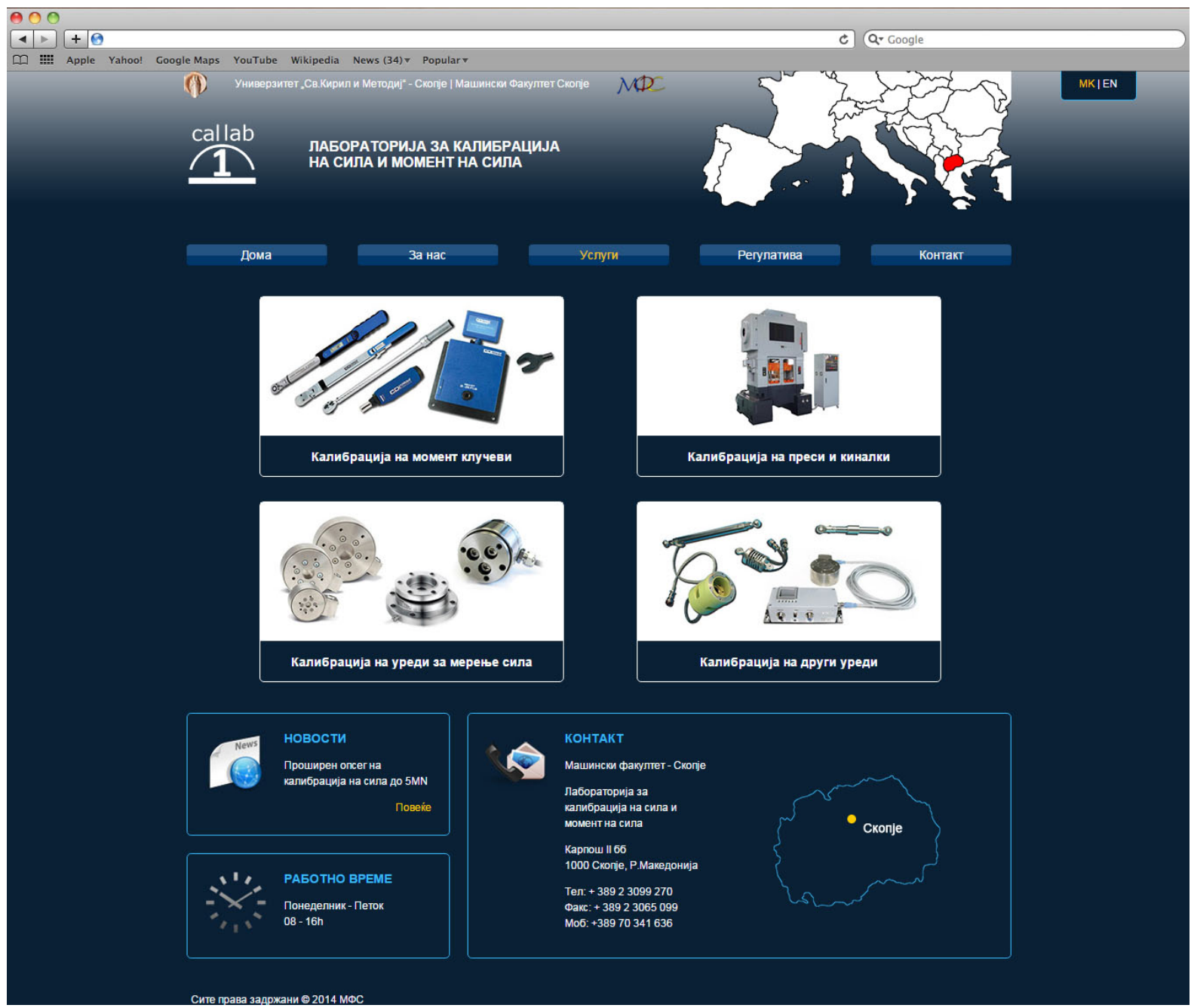

Слика 71 - Типска веб страница (,Услуги“) на Лабораторијата за калибрација на сила и момент на сила (целосен приказ) 


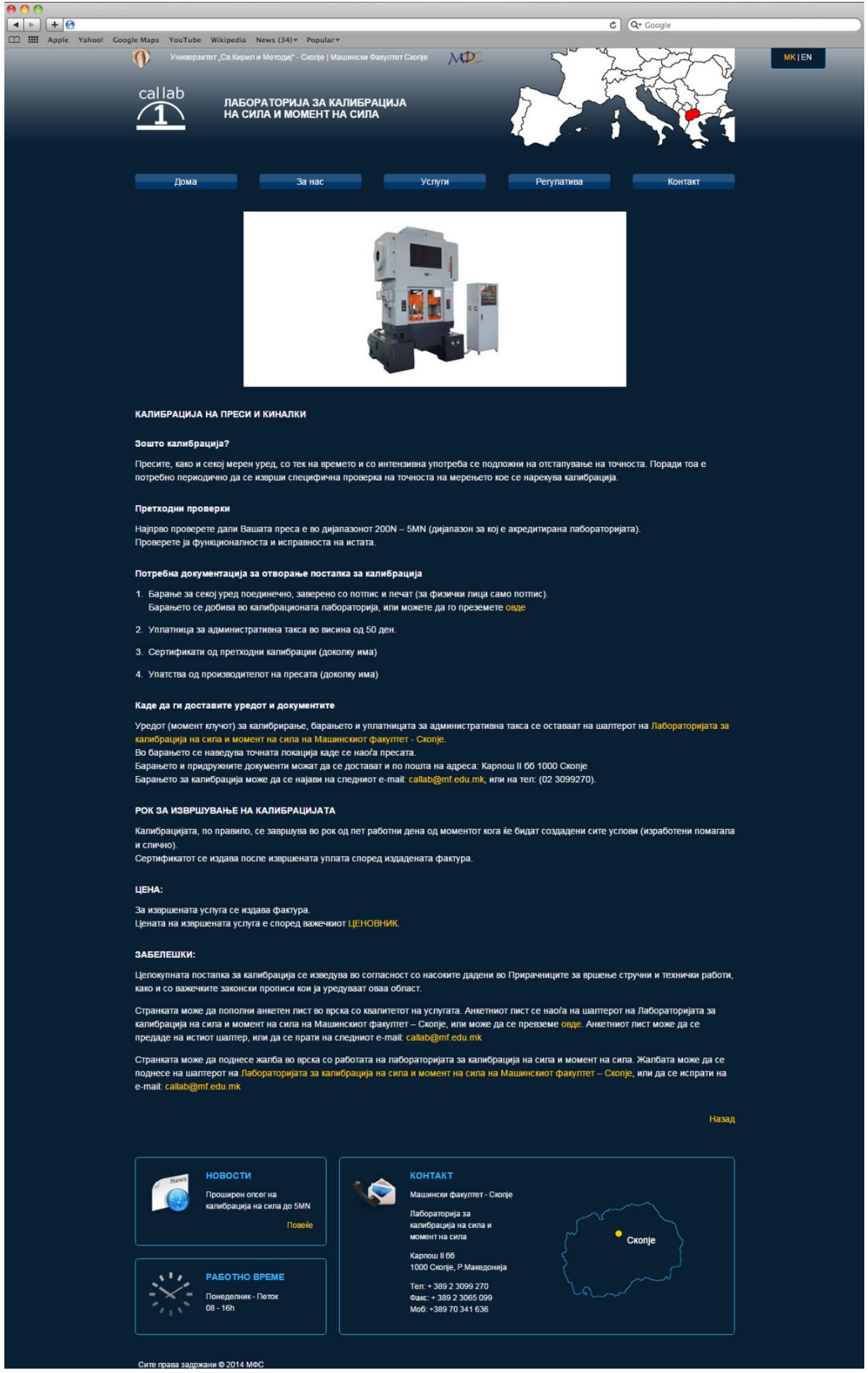

Слика 72 - Типска веб страница („Калибрација на преси и киналки“) на Лабораторијата за калибрација на сила и момент на сила (целосен приказ) 


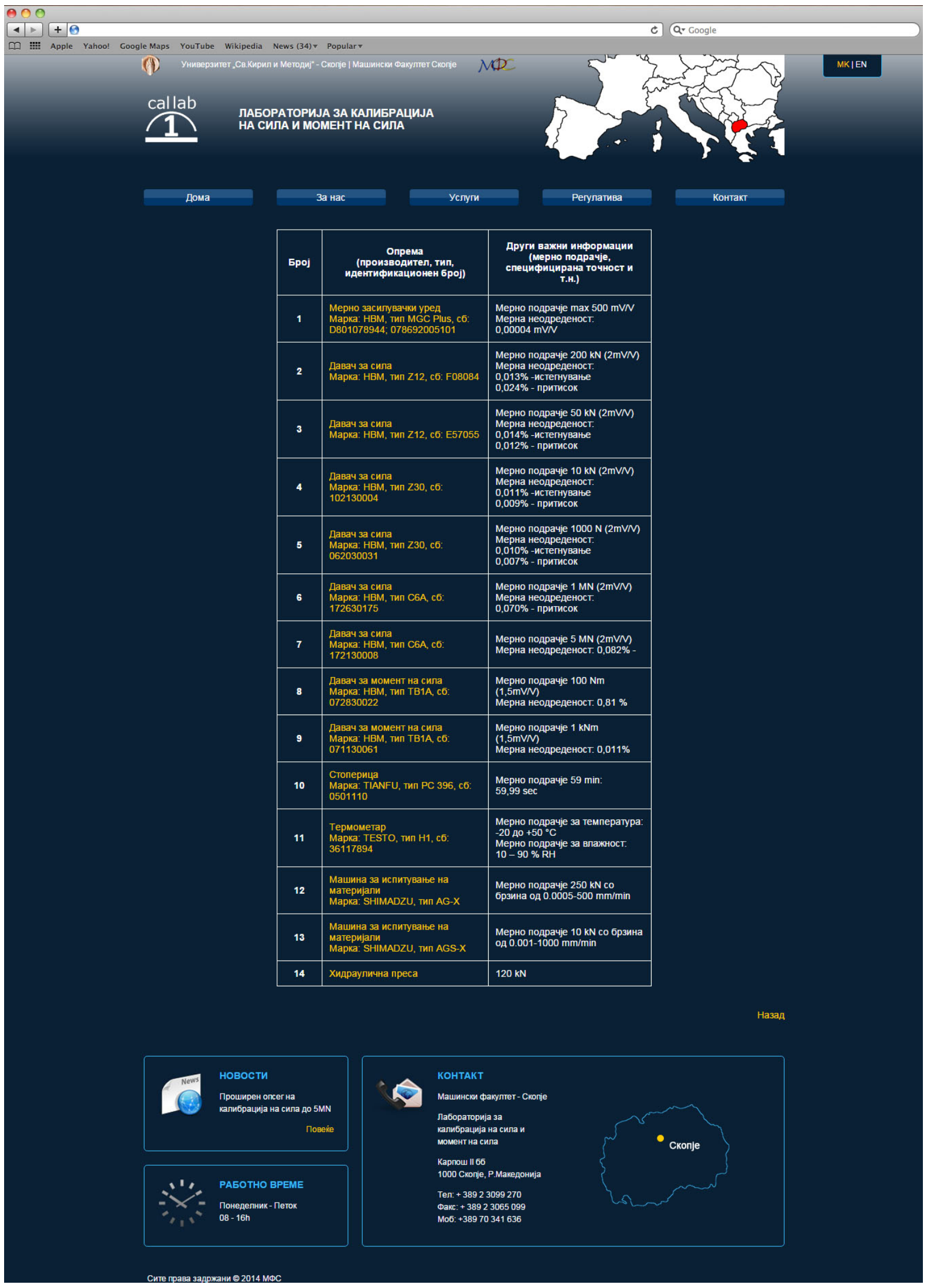

Слика 73 - Типска веб страница („Опрема“) на Лабораторијата за калибрација на сила и момент на сила (целосен приказ) 


\subsection{3 Веб локација на лабораторијата за калибрација на сила и момент на сила}

Акредитирањето на лабораторијата за тестирање на механички карактеристики, машини и возила од страна на ЦИРКО ДООЕЛ во почетокот на 2015 година ја наметна потребата за креирање соодветна веб локација во релативно краток временски период.

Заради конзистентност во дизајнот, особено заради тоа што се работи лаборатории кои нудат услуги во рамките на ЦИРКО ДООЕЛ, беше одлучено дизајнот на новата веб локација за лабораторијата за тестирање на механички карактеристики, машини и возила ${ }^{58}$ да биде во склад со дизајнот на веб локацијата на лабораторијата за калибрација на сила и момент на сила. Меѓутоа, во овој случај најголем акцент беше ставен на читливоста на содржината и намалувањето на заморот на очите. Заради тоа избрана е неутрална позадина и темна боја на текст. Дополнително, заради сѐ поголемата употреба на мобилните уреди за прегледување на веб локации и самиот факт што за прв пат се создава веб локација за оваа лабораторија, при изработката е применет прилагодлив веб дизајн.

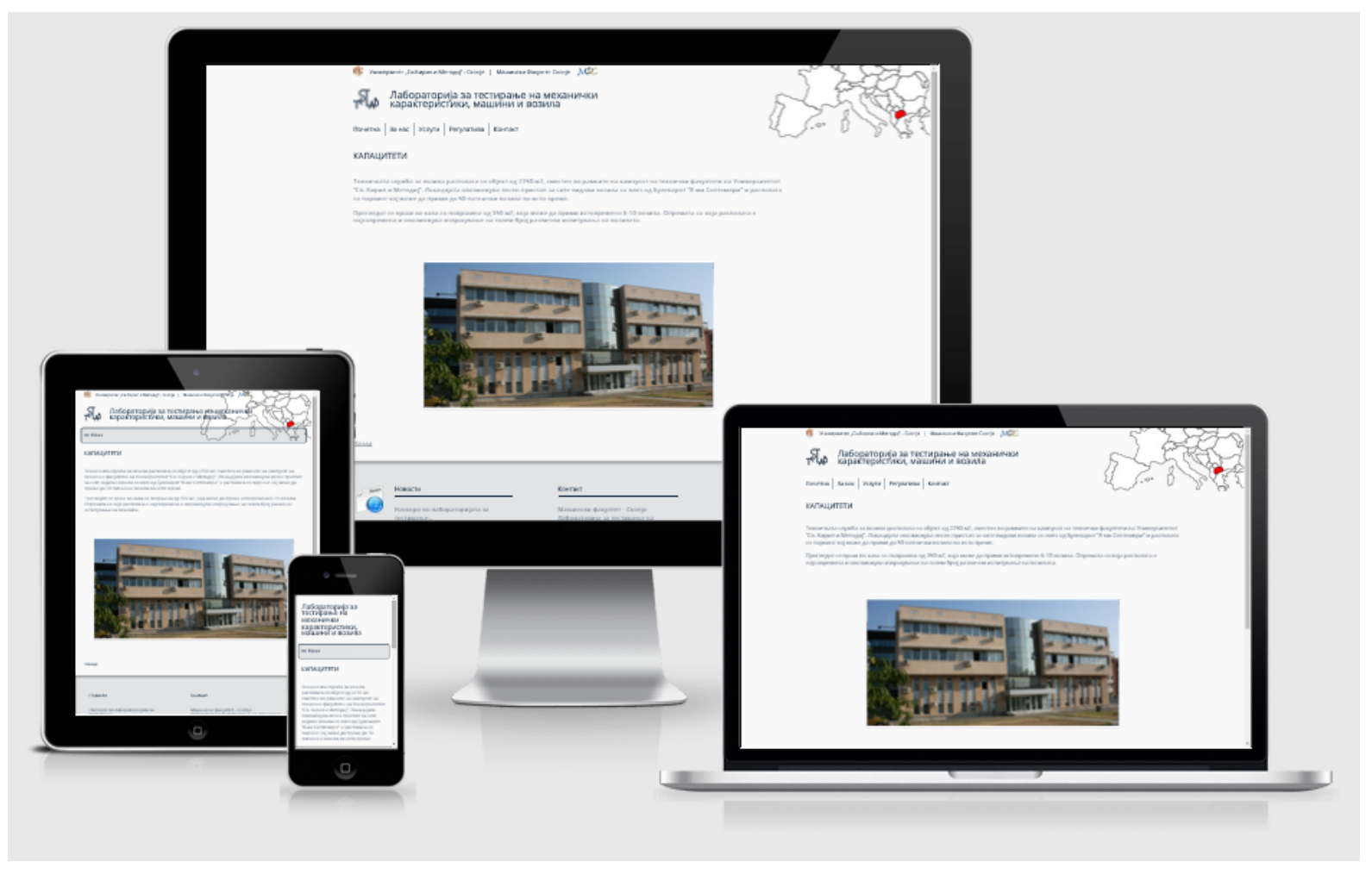

\footnotetext{
${ }^{58}$ www.testlab.mf.edu.mk
} 

и возила (приказ на прилагодлив веб дизајн)

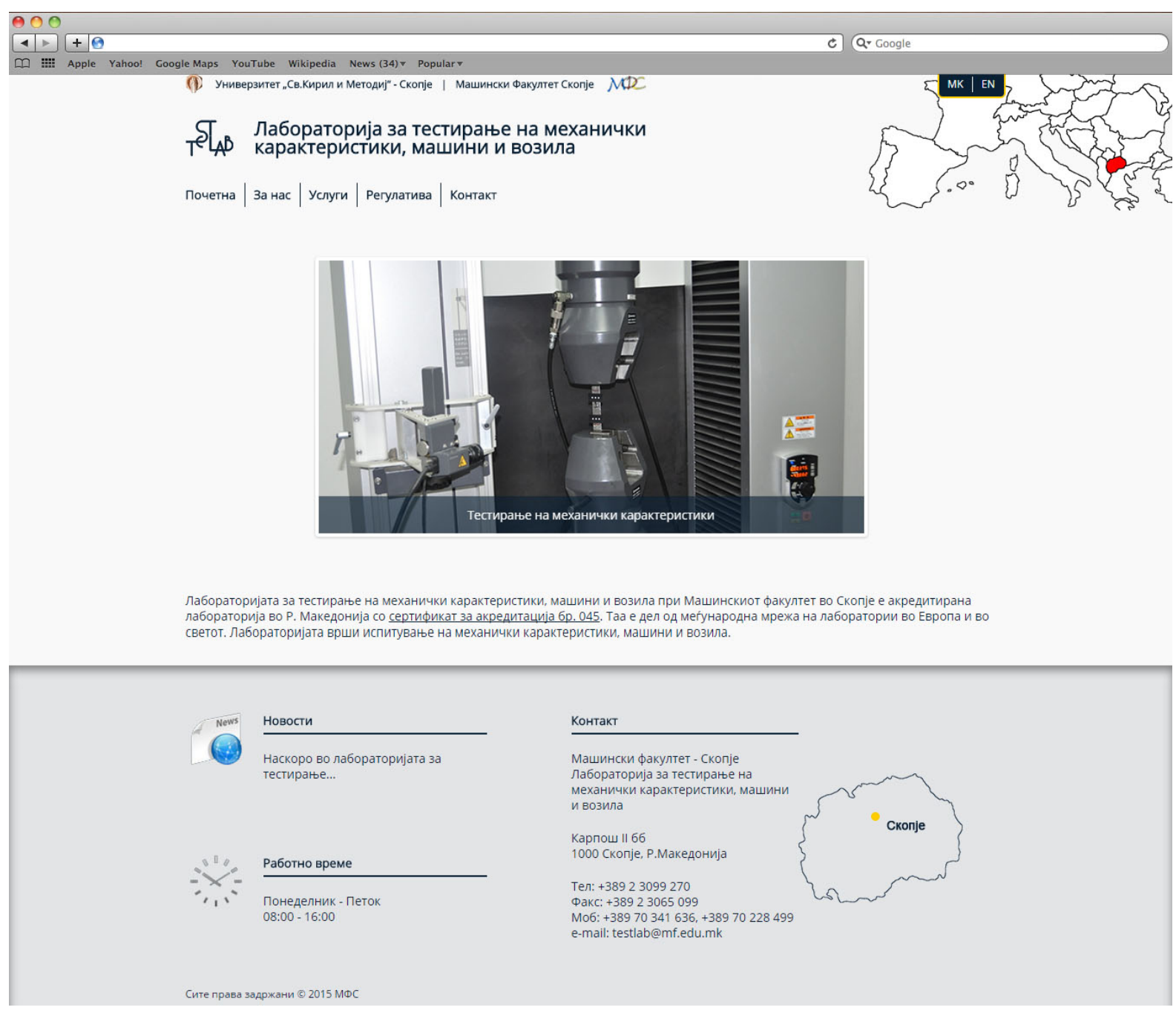

Слика 75 - Почетна веб страница на Лабораторијата за тестирање на механички карактеристики, машини и возила (целосен приказ) 


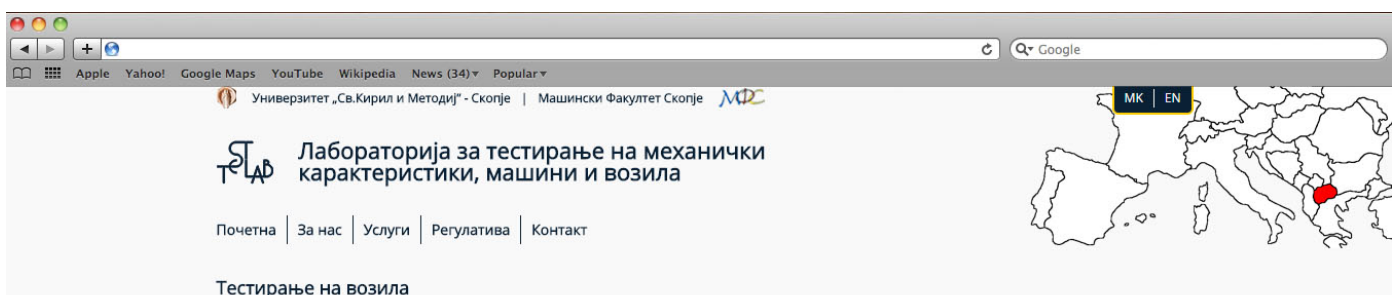

Тестирање на возила

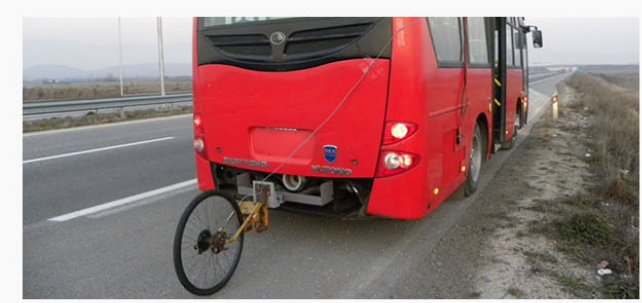

Лабораторијата за тестирање на механички карактеристики, машини и возила, во делот на тестирање на возила спроведува тестови на Ладераторијата за тестирање на механички карактеристики, машини и возила, во делот на тестирање на возила спроведува тестови на возилата, нивните составни делови, системи и самостојни технички единици, согласно методологија дадена во одделни пропиии, како и согласно методологија по барање од, или усогласена со нарачател.

Посебна карактеристика на лабораторијата е кадровско - техничкиот капацитет да прави експертизи поврзани со сложени откази на возилата, заштита од преоптоварување, снимање на работните оптоварувања, определување на оптимални и гранични режими на (2)

Лабораторијата има развиено сериозен капацитет и за современите методи на виртуелни тестирањ
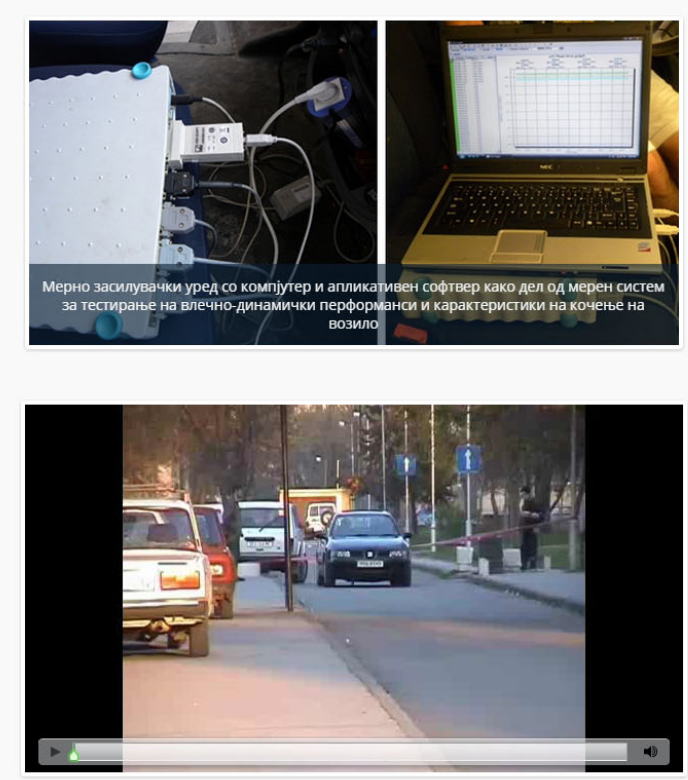

Назад

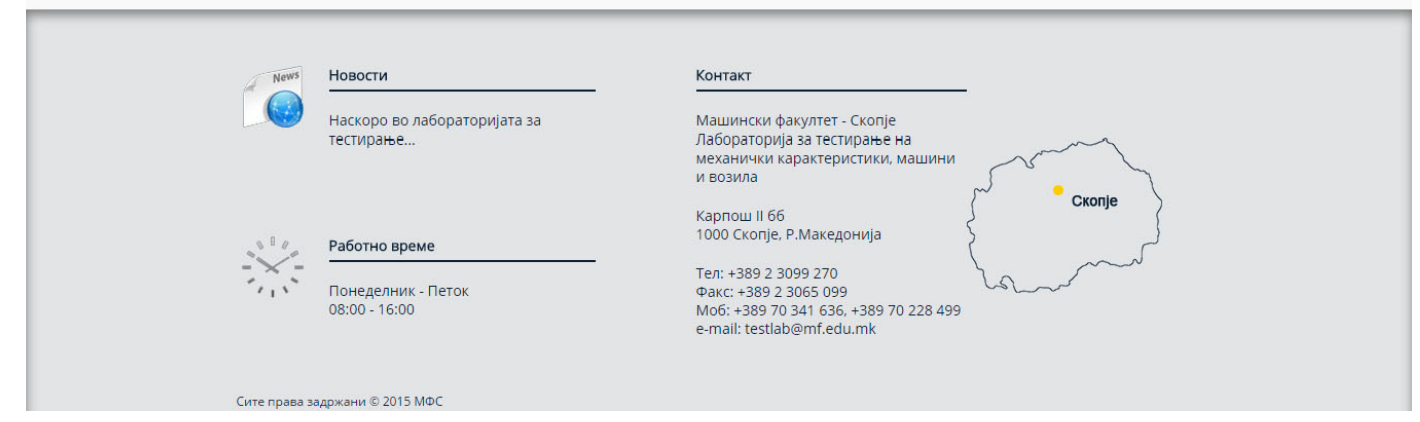

Слика 76 - Типска веб страница (,Тестирање на возила") на Лабораторијата за тестирање на механички карактеристики, машини и возила (целосен приказ) 


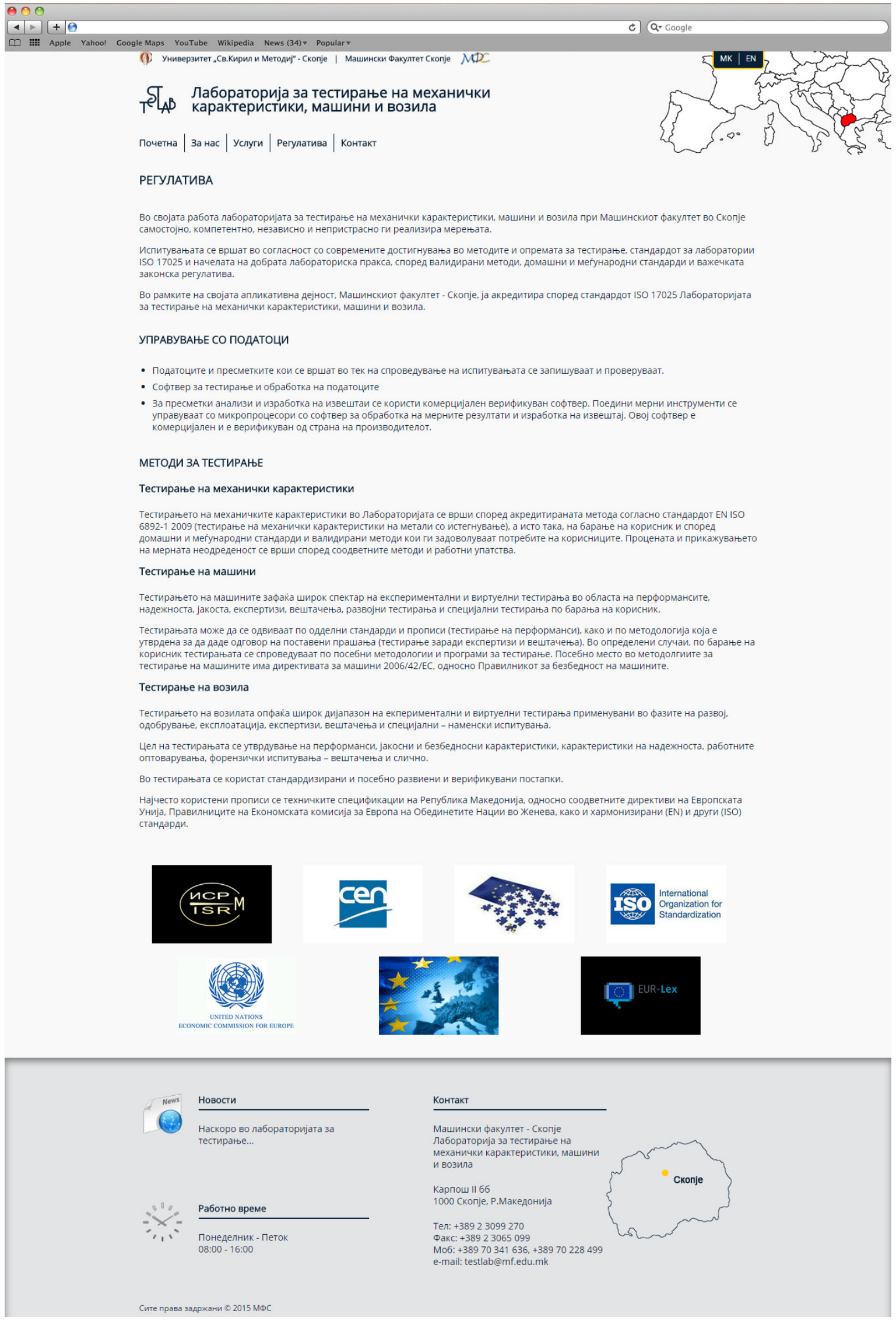

Слика 77 - Типска веб страница („Регулатива“) на Лабораторијата за тестирање на механички карактеристики, машини и возила (целосен приказ) 


\subsection{4 Веб локација на техничката служба за возила}

Последна веб локација која беше редизајнирана, а воедно е и најстарата веб локација од секторите на цИРКО ДООЕЛ е веб локацијата на техничката служба за возила ${ }^{59}$. Станува збор за една поголема веб локација во споредба со останатите од веб порталот на ЦИРКО ДООЕЛ, која е посетувана од повеќе различни групи корисници и заради тоа имаше потреба од тријазичност на содржините. Првичниот редизајн беше изработен во рамките на мојата дипломска работа, меѓутоа, се појави потреба од одредени измени, пред сѐ, поради поминатото време во кое самиот развој на информатичката технологија во областа на веб дизајнот беше веќе доста напреднат. Беше неопходна преработка на веб локацијата со примена на прилагодлив веб дизајн. Направените измени особено се видливи во делот на навигацијата, која сега има поедноставен изглед, но зголемена функционалност (за соодветна употреба кај мобилните уреди). Кај претходната верзија боите јасно го истакнуваа веќе утврдениот бренд идентитет на техничката служба за возила, поради што беше неопходно да биде соодветно применет и во редизајнот.

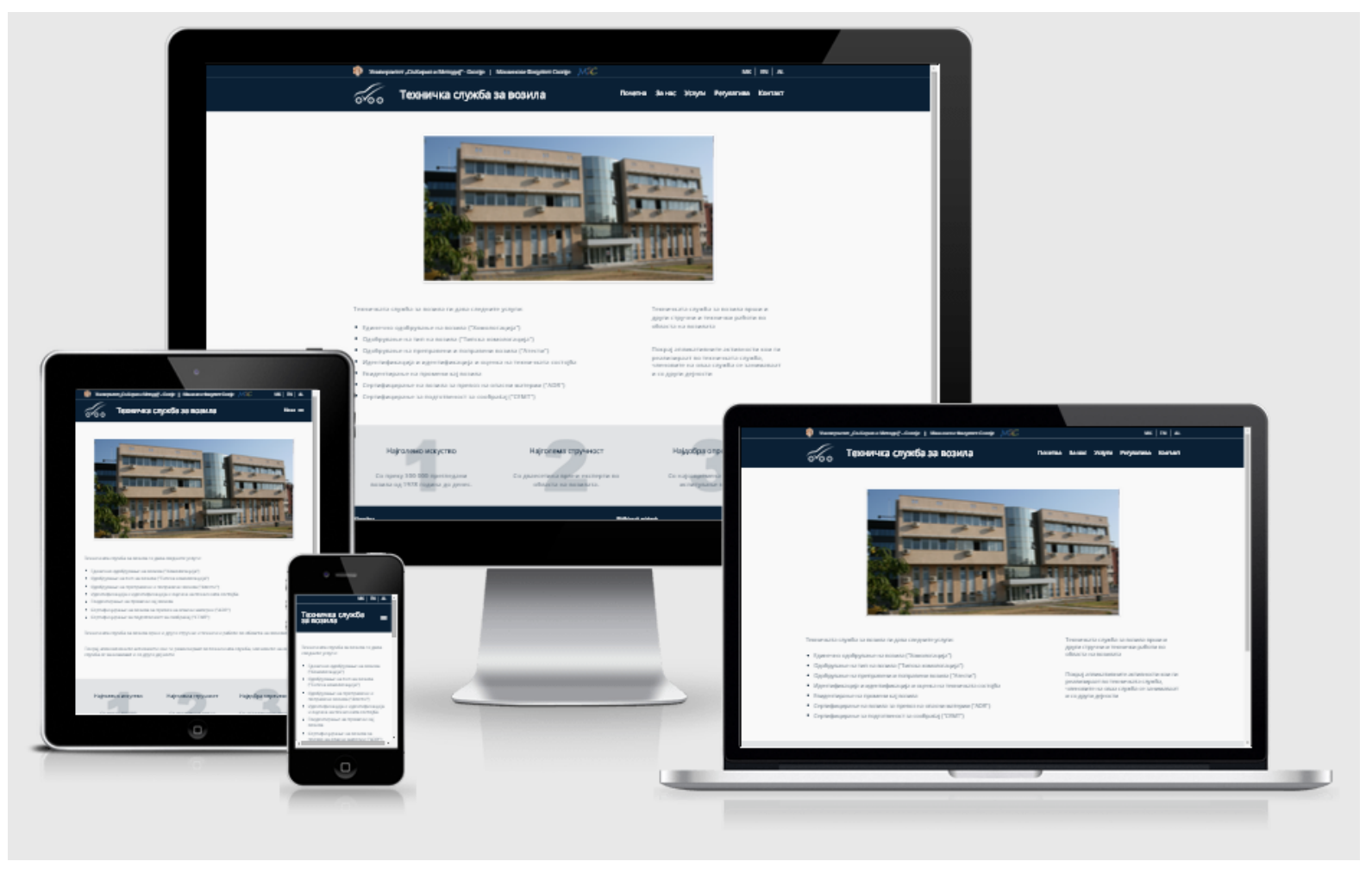

Слика 78 - Веб локација на Техничката служба за возила (приказ на прилагодлив веб дизајн)

\footnotetext{
${ }^{59}$ www.vozila.mf.edu.mk
} 

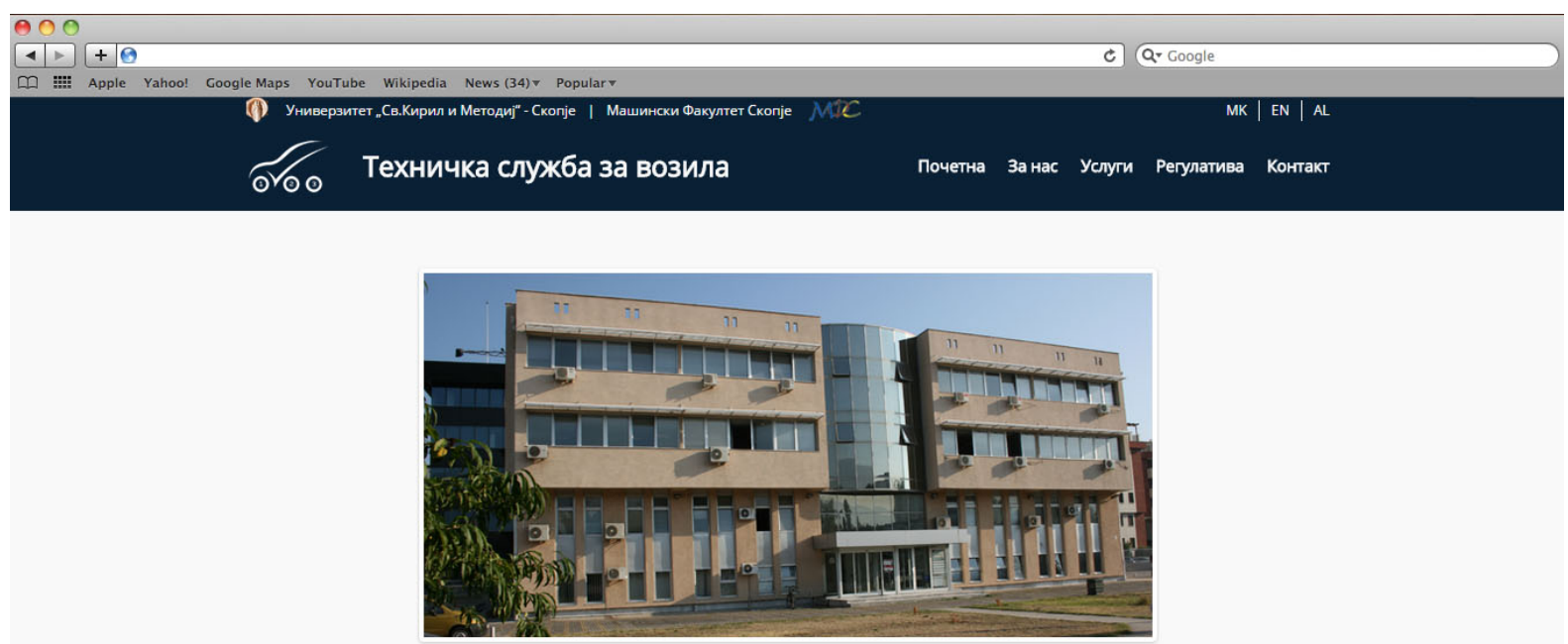

Техничката служба за возила ги дава следните услуги:

- Единечно одобрување на возила ("Хомологација")

- Одобрување на тип на возила ("Типска хомологација")

- Одобрување на преправени и поправени возила ("Атести")

- идентификација и идентификација и оценка на техничката состојба

- Евидентирање на промени кај возила

- Сертифицирање на возила за превоз на опасни материи ("ADR")

- Сертифицирање за подготвеност за сообраќaj ("СЕмт")
Техничката служба за возила врши и други стручни и технички работи во областа на возилата

Покрај апликативните активности кои ги реализираат во техничката служба, членовите на оваа служба се занимаваат и со други дејности

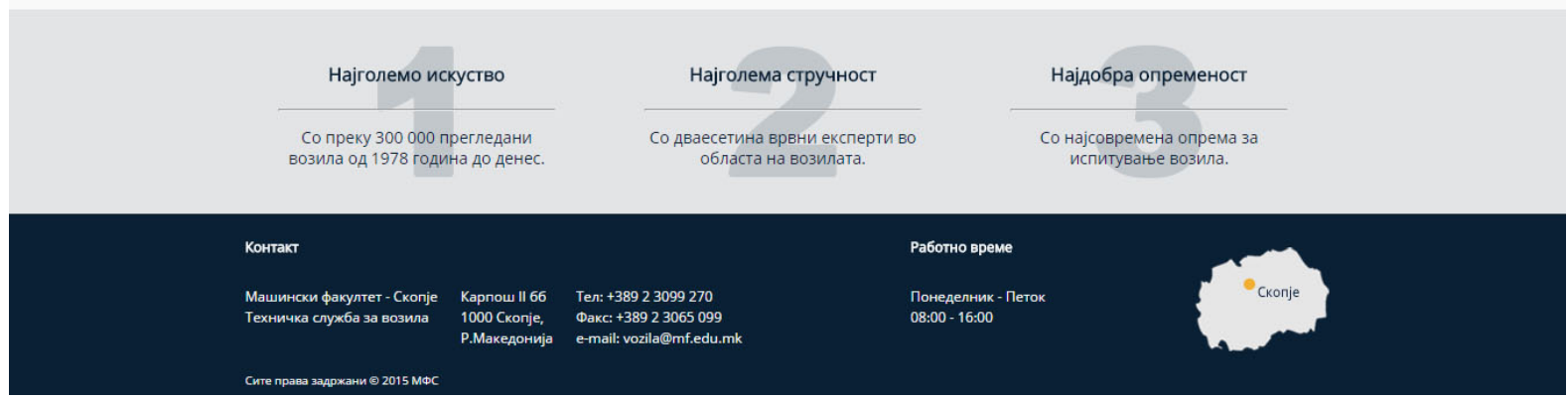

Слика 79 - Почетна веб страница на Техничката служба за возила (целосен приказ) 


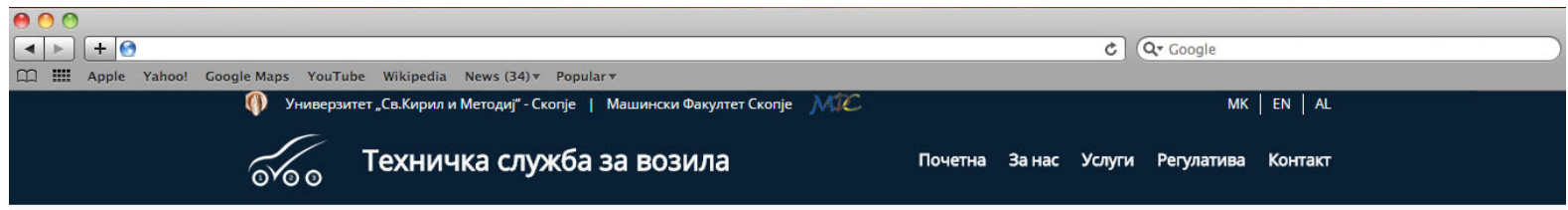

3A HAC

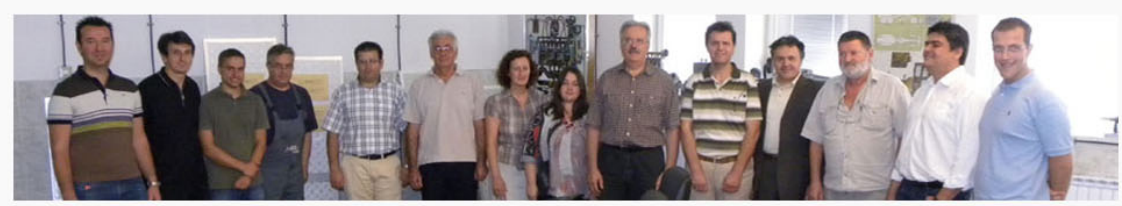

НАША ВИЗИЈА

Мегуународно распознатливо инспекциско тело во областа на машинството.

НАША МИСИЈА

Вршење на инспекција:

- според прописите, домашните и меѓународните стандарди:

- со примена на најновите достигнувања во методите и опремата за контрола:

- согласно со потребите и барањата на корисниците на услугите.

НАША ПОЛИТИКА ЗА КВАЛИТЕТ

целосно исполнување на барањата на корисниците со почитување на законската регулатива и стандардите:

- висок квалитет на секоја инспекција, за секој корисник

- реализација на инспекциската дејност без финансиски и политички влијанија

- применување, одржување и подобрување на системот за управување со

- однос со корисниците и Институтот за акредитација на Република Македонија базиран на взаемна доверба и почитување:

- осигурување на независноста и непристрасноста на сите членови на инспекциското тело, како и непостоењето на конфликт на интереси кај нив:

- постојано подобрување на квалитетот на инспекциите со усовршување на кадарот и воведување на нови методи и опрема за инспекција:

- соработка и размена на искуства со други слични тела од областа: - осигурување на доверливост на информациите добиени од корисниците и
Историјат

Техничката служба за возила своите активности ги отпочна паралелно со почнувањ раните 70-ти гонини о ХХ

Повеќе...

Дејности

Покрај апликативните активности кои ги реализираат во техничката служба служба се занимаваат

- наставна

- научно-истражувачка

- применети истражувања

- обуки и други тренинг активности

Повеќe...

Персонал

Персоналот на техничката служба го сочинуваат 15 лица со просечно искуство во областа од 10 години.

Повеќк...

Капацитети

Техничката служба за возила располага со објект од 2250 м2, сместен во рамките Универзитетот "Св. Кирил и Методиі".

Повеќе...

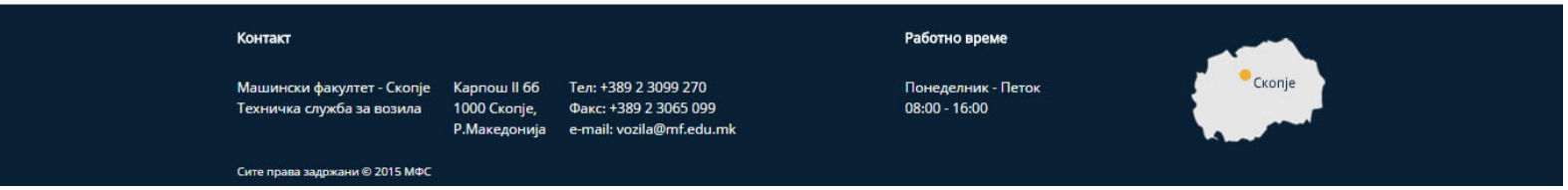

Слика 80 - Типска веб страница (,за нас“) на Техничката служба за возила (целосен приказ) 


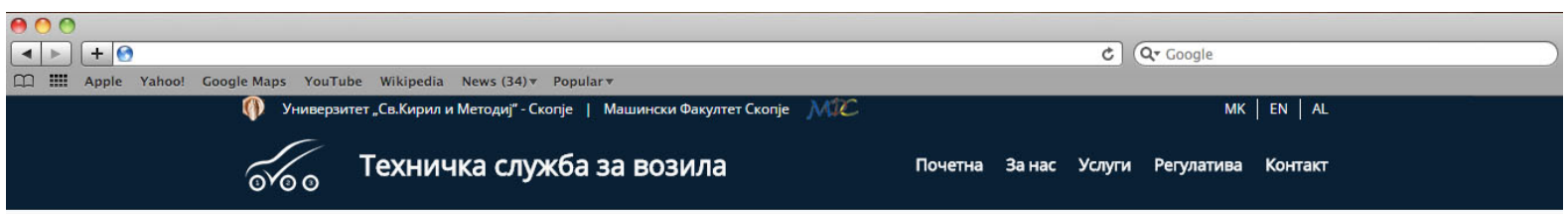

ЕДИНЕЧНО ОДОБРУВАҢЕ НА ВОЗИЛО ("ХОМОЛОГАЦИЈА")

Постапката Единечно одобрување ("хомологација") се спроведува во следните случаи:

- При увоз на возила (нови и половни):

- Единечно произведени возила (приколки и сл.)

- Возила преправени пред прва регистрација во Р. Македонија

1. за возило за кое типот не е одобрен во согласност со хармонизираните прописи за ЕУ одобрување на тип, ниту постои одобрение на типот во Република Македонија, а за кое се исполнети барањата согласно одредбите на Законот за возила и прописите донесени врз негова основа.

2. за уникатно возило, за возило за специјална намена, кое, како и за возило во последната фаза од повеќефазно одобрување за возилата опфатени со Правилникот за единечно одобрување на возила (Службен весник на Република Македонија бр. 16/2010) и неговите измени и дополнувања.

3. за возило чиј што тип е одобрен во согласност со хармонизираните прописи за

ЕУ одобрување на тип, или постои одобрение на типот во Република Македонија, но истото не било регистрирано, а е преправено, односно на возилото била извршена промена која:

- ги опфаќа податоците кои се евидентираат во постапката за регистрација на возилото:

- бара промена на категоријата на возилото:

влијае на одобрените составни делови, системи и самостојни технички единици, односно

- влијае или може да влијае на безбедноста на возилото
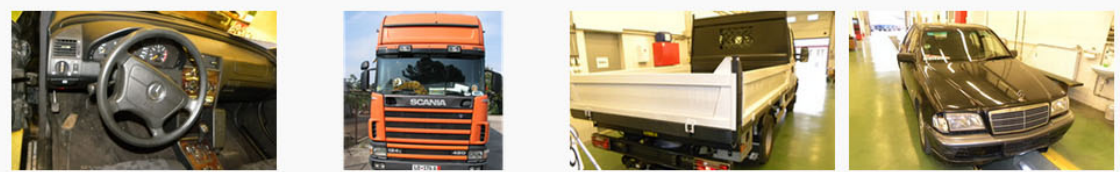

ПОСТАПКА:

- Возилото и приложената документација се прегледуваат и странката се известува за натамошните фази во постапката и начинот на кој ке бидеинформирана за превземањето на готовите документи. Странката се информира за начинот на плаќање за извршената Услуга. ЦЕНОВНИК

- Доколку врз основа на извршениот преглед на возилото од постапката се констатира дека постои целосна усогласеност со барањата за одобрување, Техничката служба до органот за одобрување, Биро за метрологија, поднесува извештај во кој се потврдува дека единечно прегледаното возило ги исполнува пропишаните барања.

- Во спротивно, доколку констатира дека возилото не ги исполнува пропишаните барања, техничката служба до органот за одобрување доставува известување за прекинување на постапката во кое се наведени причините за прекинување. Известување за одобрување доставува известување за прекинување на постапката во кое
прекинување на постапката се доставува и до подносителот на барањето.

- Врз основа на добиено одобрение за единечно возило издадено од органот за одобрување, Техничката служба на барателот му издава документ "Потврда за сообразност за единечно одобрено возило"

- Потврдата за сообразност на единечно одобрено возило се предава при регистрацијата на возилото

- Одобрението за единечно возило се чува со возилото.

\section{ЗАБЕЛЕШКА:}

Целокупната постапка за одобрување на возила се изведува во согласност со насоките дадени во Прирачниците за вршење стручни и технички работи, како и со важечките законски прописи кои ја уредуваат оваа област.

Странката м
просторија.

Странката може да поднесе жалба во врска со работата на техничката служба.

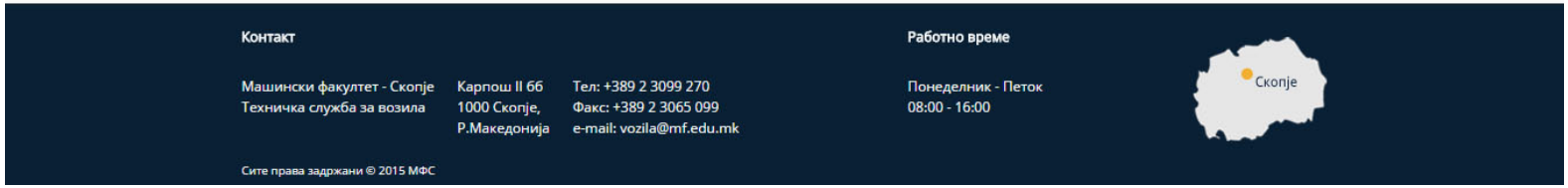

Слика 81 - Типска веб страница („Хомологација“) на Техничката служба за возила (целосен приказ) 


\section{2. Структура на веб локацијата за компанијата ЦИРКО ДООЕЛ Скопје}

Конечно, по извршување на предвидените измени на веб локациите на секторите, се премина на изработка на главната веб локацијаб ${ }^{60}$ на ЦИРКО ДООЕЛ Скопје, која ги поврзува сите нив во еден вид веб портал.

Секогаш при веб дизајнирањето треба да се започне со креирање на структура на веб локацијата. Најдобар начин за претставување на структурата е дијаграм на кој прегледно може да се забележи бројот и распоредот на страниците, како и нивното поврзување.

Од дијаграмот прикажан понатаму може да се забележи дека е предвидено веб локацијата да се состои од четири главни страници, кои во себе имаат неколку сегменти. Меѓутоа, заради потребата од олеснето движење низ содржините на самата веб локација со лизгање преку екранот на допир при користење на мобилни уреди, беше неопходно истата да биде креирана во вид на една долга веб страница која има повеќе секции.

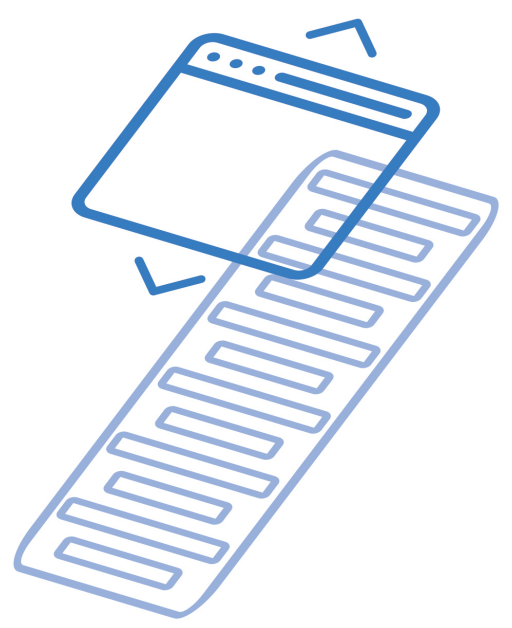

Слика 82 - Шематски приказ на веб локација соединета во една (голема) веб страница

\footnotetext{
${ }^{60}$ www.cirko.mk
} 


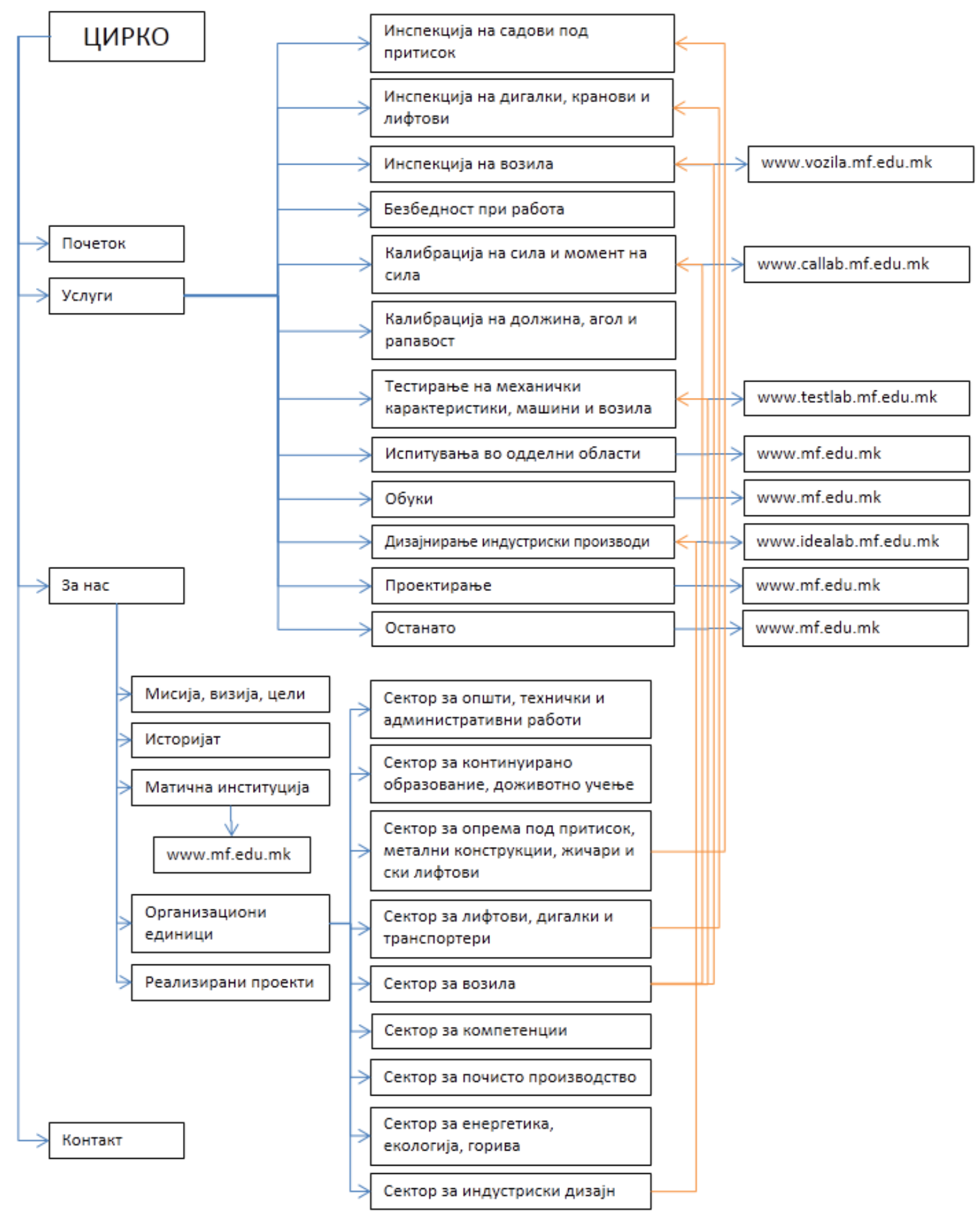

Слика 83 - Дијаграм на структурата на веб локацијата на компанијата ЦИРКО ДООЕЛ Скопје 


\section{3. Дефинирање на потребите и барањата кои се очекува да ги исполни веб локацијата на ЦИРКО ДООЕЛ Скопје}

Врз основа на извршените истражувања во претходните поглавја, согласно сознанијата за факторите кои влијаат врз дизајнот на веб страниците, излечени се следните заклучоци во врска со барањата и условите кои треба да ги исполни дизајнот на веб локацијата на Центарот за истражувања, развој и континуирано образование:

- Правилна примена на Гешталт принципите, со цел подобро уредување на содржините и воспоставување визуелна хиерархија

- Визуелно разграничување на секциите кои ја составуваат веб страницата, на пример преку употреба на различна обоеност на позадината

- Конзистентност во уредувањето на содржините во сите секции на веб страницата

- Употреба на бои кои го истакнуваат корпоративниот идентитет на компанијата и се во координација со останатите веб локации кои се дел од ЦИРКО

- Употреба на неутрални бои за позадина за да не се оптоваруваат очите на посетителите

- Употреба на тип на фонт со изглед и големина на карактери кој е едноставен за препознавање и следствено за читање преку различните мобилни уреди

- Соодветно димензионирање на копчиња за корисници на мобилни уреди

- Прикажување на содржините на начин кој е поддржан од најголемиот дел прегледници

- Умерена употреба на графички елементи, за да се постави акцент на текстуалната содржина и да се истакне професионалноста

- Фиксирање на навигацијата во горниот дел заради поедноставно движење низ страницата

- Поставување впечатливи содржини над преклопот

- Овозможување клиентот по своја желба да добие повеќе детали за посакуваните содржини (услуги), наместо прикажување на огромна количина содржина одеднаш 
Како приоритетен услов при дизајнирањето на веб локацијата на ЦИРКО ДООЕЛ беше нагласена примената на прилагодлив веб дизајн, не само заради актуелниот тренд, туку и заради реално сѐ поголемата употреба на мобилните уреди за прегледување веб локации. Во овој момент Интернет корисниците се инертни во однос на употребата на мобилни апликации за прегледување содржини од мобилни уреди, така што употребата на прилагодлив веб дизајн беше единствено прифатлива.

Иако станува збор за пристап агностичен на уреди, треба да се испита како би се прикажувала веб локацијата на некои покарактеристични резолуции на мобилни телефони, бидејќи тие се поексплоатирани од таблетите во моментов. Според корисниците, следен аспект на кој што треба да се посвети внимание при дизајнирањето на прилагодливи веб страници е распоредот на содржините, бидејќ можноста брзо и едноставно да ги најдат потребните информации им е од огромно значење. Во однос на програмирањето, најмногу внимание треба да се посвети веб локацијата правилно да се прикажува на прегледникот Google Chrome, затоа што најголем дел од испитаниците најчесто го користат токму овој прегледник.

По извршената анализа на предностите и недостатоците на конкурентските веб локации, согледувањето на барањата на посетителите и очекувањата на нарачателот на веб локацијата, изработени се неколку концепти за изгледот на веб локацијата на ЦИРКО ДООЕЛ - СКопје. 


\section{4. Предлог концепти за веб локацијата за компанијата ЦИРКО ДООЕЛ}

\section{Скопје}
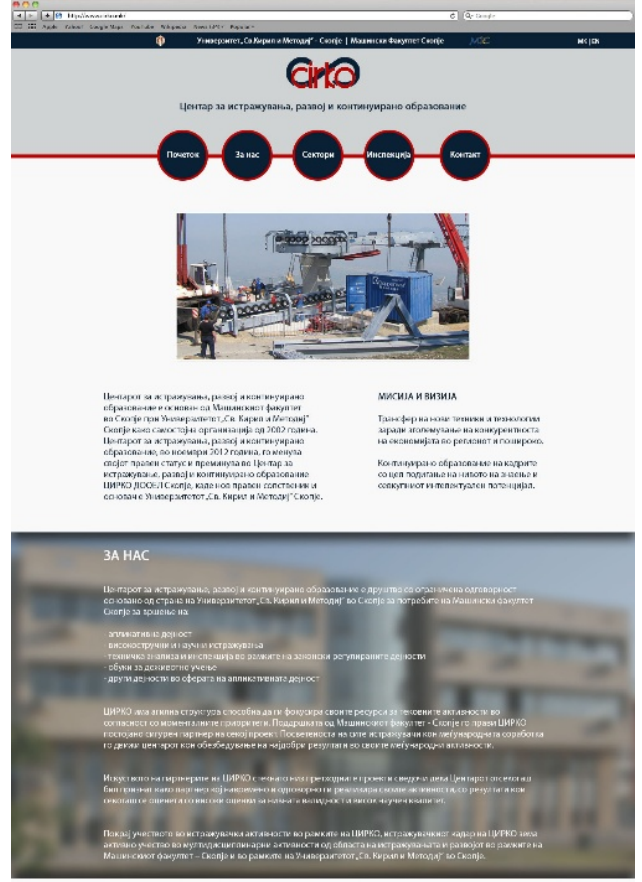

СЕКТОРИ
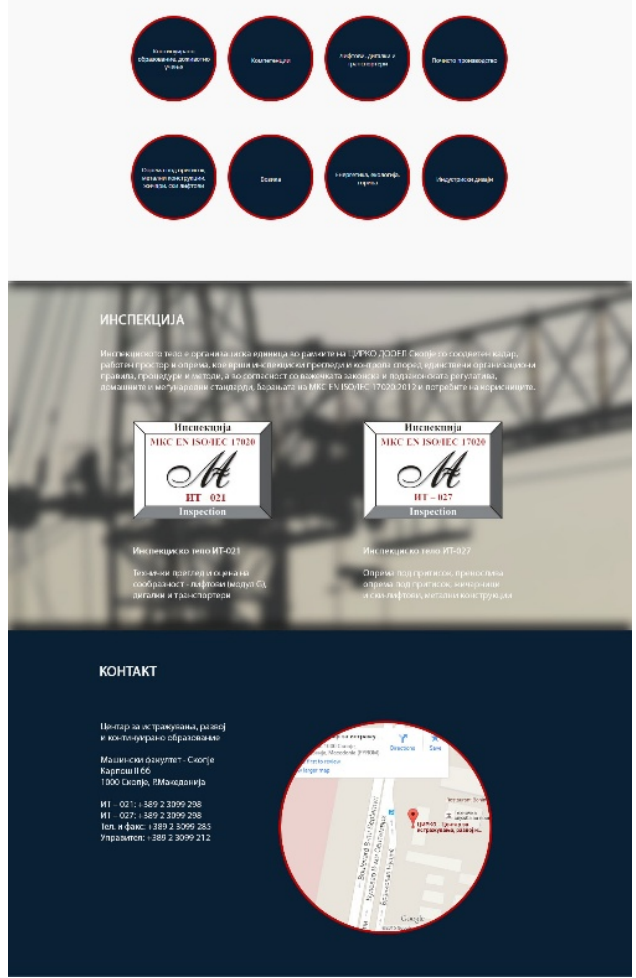

Слика 84 - Кониепт бр.1 (иелосен приказ)

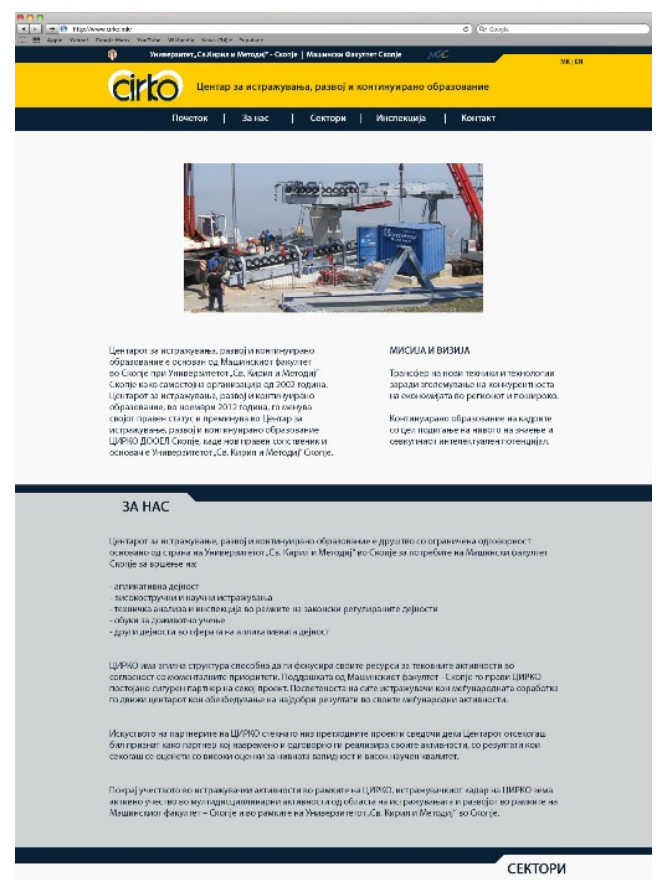

画 居

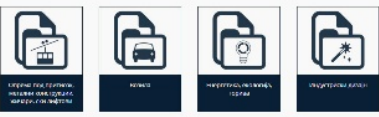

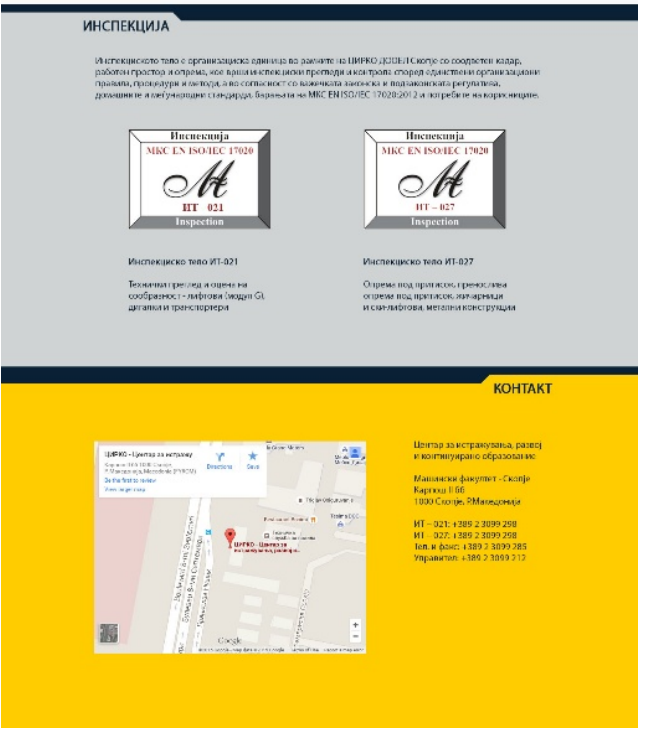

Слика 85 - Концепт бр.2 (целосен приказ) 
При дизајнирањето на првиот концепт најзначајно беше влијанието на трендот на поставување слики со висока резолуција како позадина на некои сегменти на веб страниците, така што мислев дека добро се вклопува и со идејата за веб страницата на ЦИРКО. Меѓутоа, за да се истакне подобро содржината и да не се придава премногу значење на содржините во сликите, истите ги заматив. Дополнително на тоа, вметнав и елементи и копчиња со кружен облик, што исто така во последно време е тренд во интерфејс дизајнот.

Вториот концепт на кратко може да се опише како рамен дизајн со мали футуристички детали. Тој делува доста сериозно и доста ја истакнува прикажаната содржина, пред сѐ затоа што нема многу графика која може да му го одземе вниманието на посетителот.

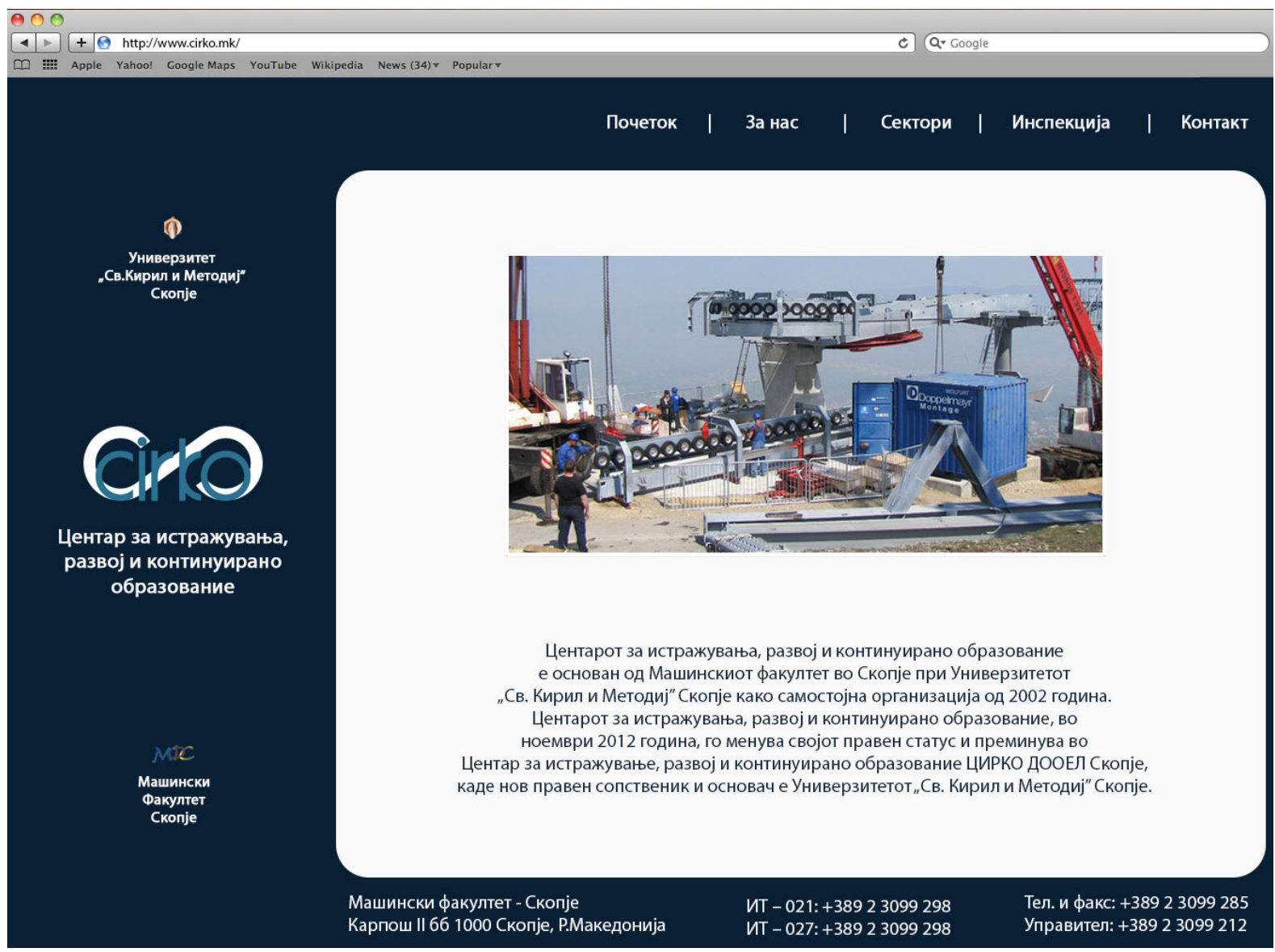

Слика 86 - Концепт бр.3, почетна страница (целосен приказ) 


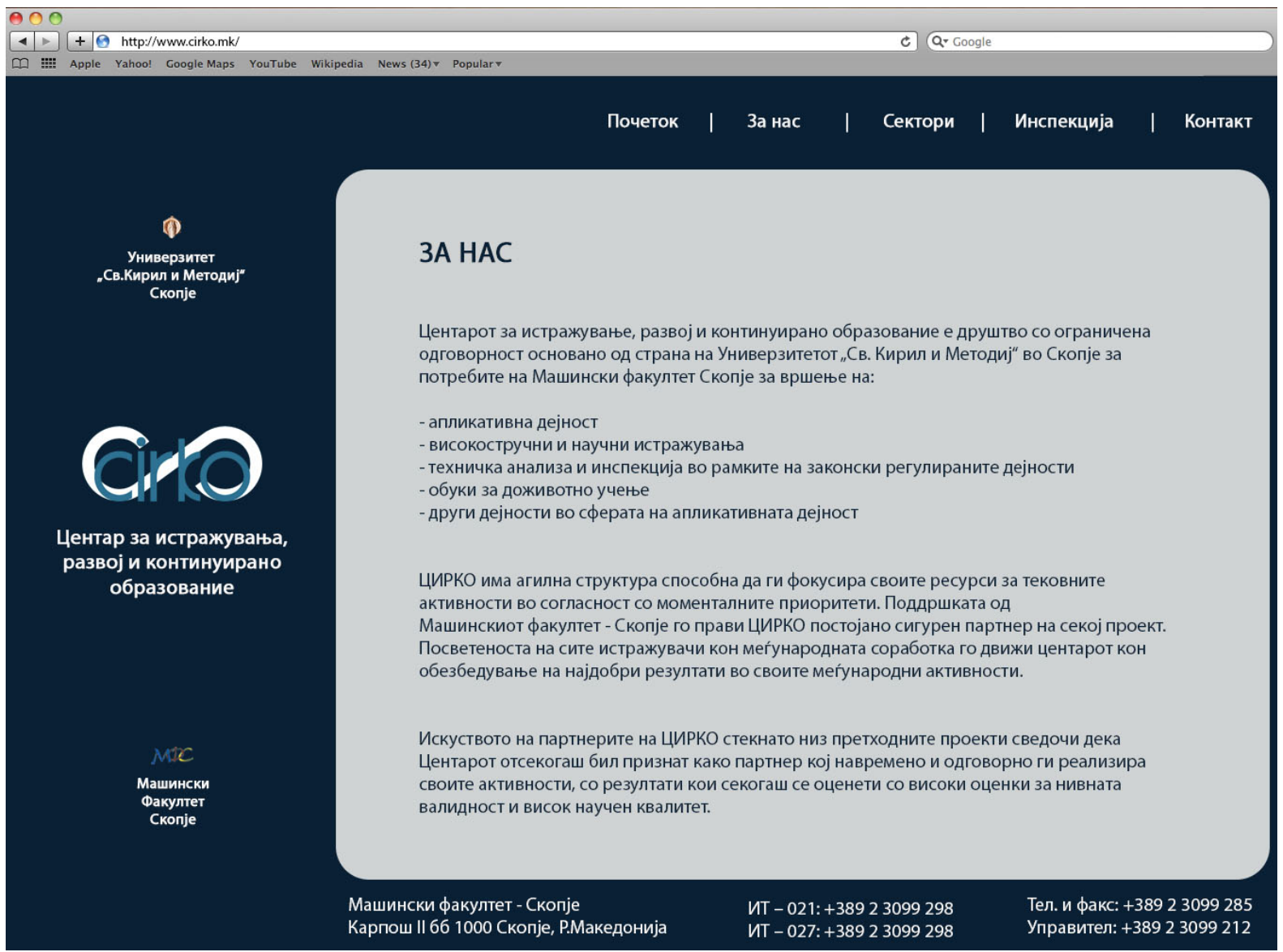

Слика 87 - Концепт бр.3, типска страница (целосен приказ)

Кај третиот концепт сакав да постигнам нешто што во моментот е ретко, а може да се каже и несекојдневно - хоризонтално движење по веб страницата. Единствен добро познат пример за овој дизајнерски пристап се веб страниците на локацијата MySpace. Но, освен тоа вметнав и рамка околу содржината, за да се добие изглед кој асоцира на веб апликација.

Ефектот на паралакса беше водечка идеја во четвртиот концепт. Повторно со помош на заматена позадина во комбинација со прозирна позадина на елементите во преден план се долови илузијата на тродимензионалност во дводимензионалниот простор. Исто така, сакав да го доловам Metro дизајнот кој го воспостави компанијата Microsoft преку дизајнот на своите интерфејси. Меѓутоа, заради зголемената употреба на овој дизајн сакав да направам нешто малку поразлично, па ги направив правоаголните модули со заоблени рабови и не ја исполнив нивната позадината со боја. 


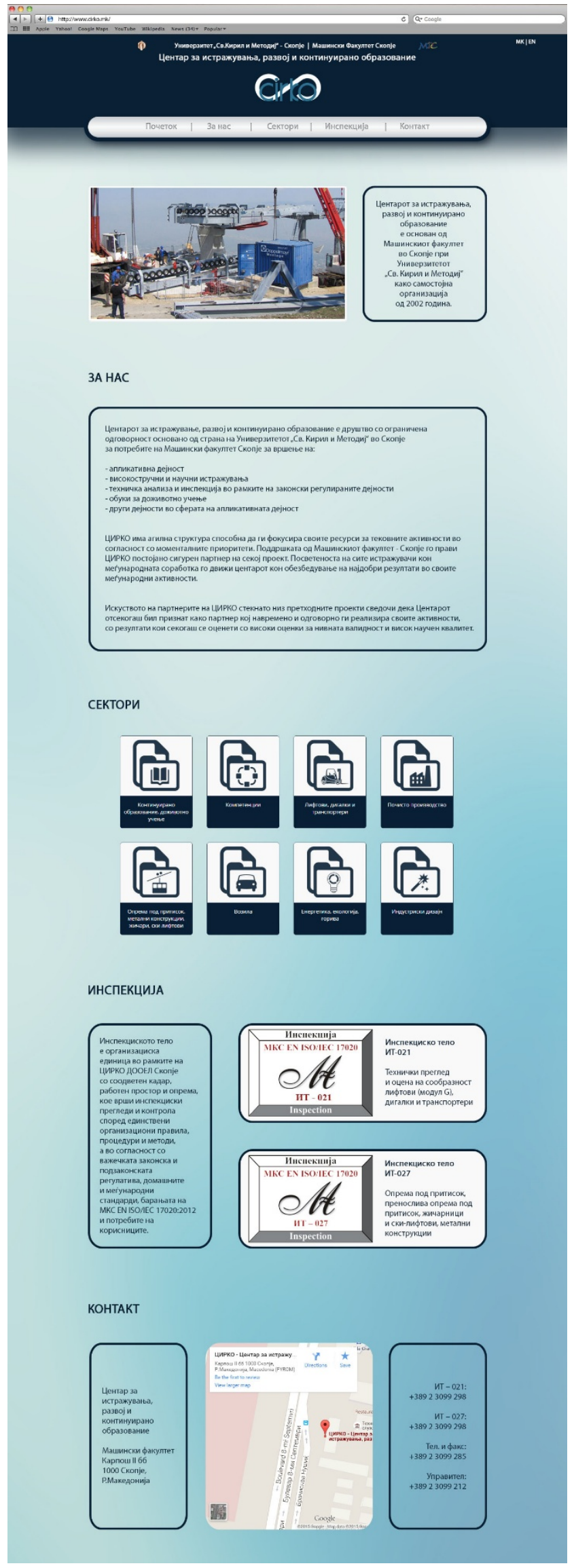

Слика 88 - Концепт бр.4 (целосен приказ) 


\section{7. Презентација на конечниот дизајн на веб локацијата и промотивниот материјал за цИРКО ДООЕЛ Скопје}

\section{1. Избран концепт за веб локацијата за компанијата цИРКО ДООЕЛ Скопје}

Постојат повеќе причини зошто е избран концептот кој е прикажан на следните слики. Но, пред сѐ, тој е избран заради сериозниот изглед, што доликува на еден центар за трансфер на технологии. Рамниот дизајн беше употребен не само заради тоа што е актуелен тренд, туку и заради потребата да се постави фокусот врз самата содржина која е прикажана на веб страницата.

Распоредот на содржината и комбинацијата на бои се следна причина зошто е избран овој концепт. Тие комуницираат сталоженост, доверба и професионалност. Дополнително, јасно е прикажана припадноста и единството со веб локациите на секторите, што е најзабележливо во горниот дел (банерот) на страницата.

Понатаму, исклучително важна беше можноста корисникот лесно да пристапи до посакуваната содржина. Бидејќи станува збор за само една голема веб страница која ја сочинува целата веб локација, освен промислено искористување на расположливиот простор на екранот, неопходно потребен беше дизајн во кој има фиксирана навигација во горниот дел на екранот. Целта на ова беше да се намали потребата за движење сѐ до врвот на страницата или општо потребата да се лута низ страницата, само за да се пристапи кон некоја друга посакувана секција. Следствено, со ова се намали и заморот на меморијата на корисникот да го помни редоследот на секциите.

Компактноста на менито и присуството на елементи кои по потреба се експандираат (за да ја прикажат содржината која ја содржат во себе) дополнително ја олеснија одлуката за избор на овој концепт. 


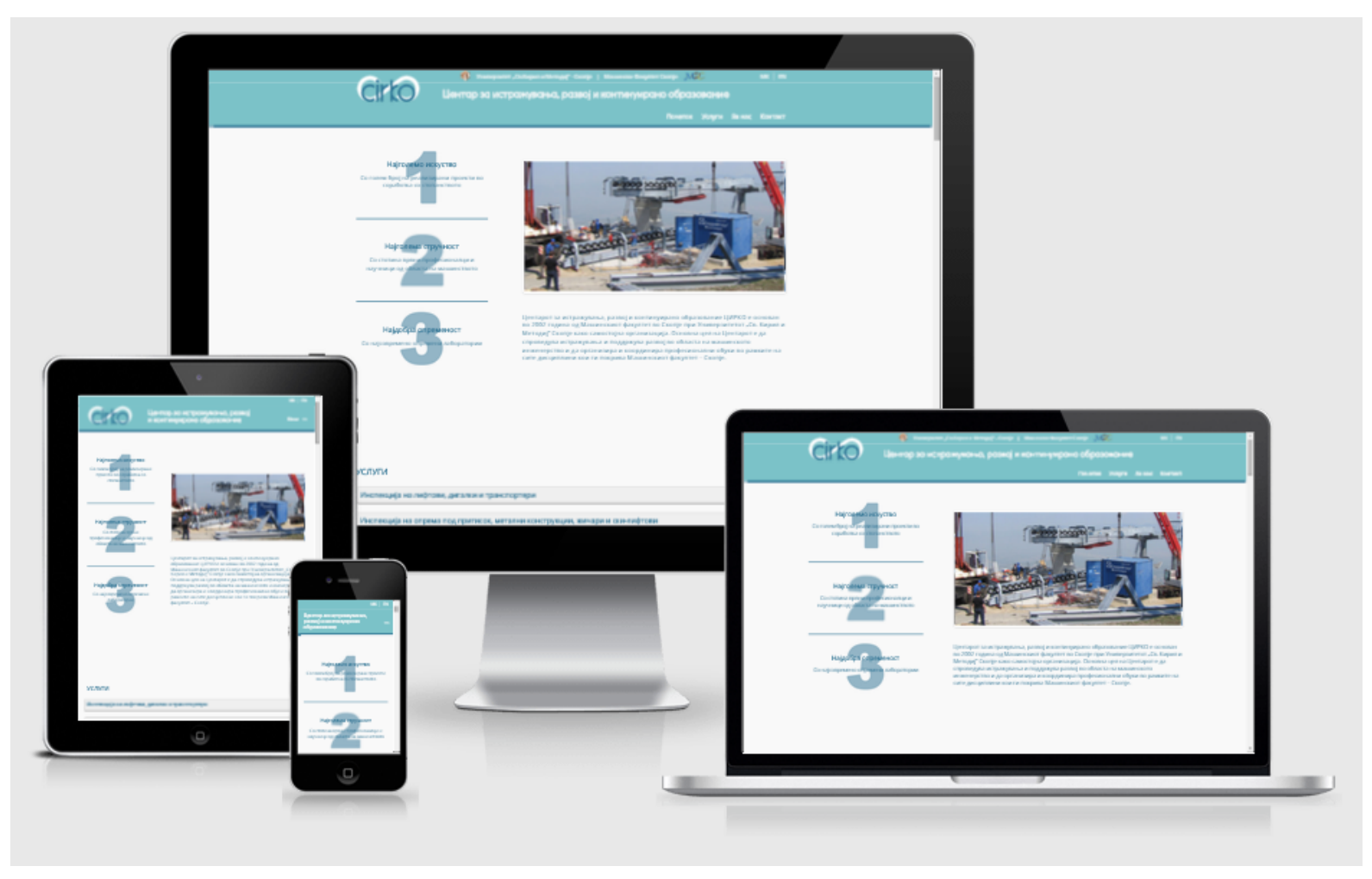

Слика 89 - Веб локација на ЦИРКО ДООЕЛ Скопје (приказ на прилагодлив веб дизајн)

Во однос на пристапот при програмирањето на прилагодливиот веб дизајн, применив Mobile First пристап. При тоа најнапред се поставени стиловите наменети за мобилните телефони, а потоа истите се надградени за да се добие изгледот на останатите уреди (соодветно). Дополнително, поставив скрипта која го спречува вчитувањето на слики само во верзијата за мобилни телефони заради остварување помал Интернет сообраќај кога се употребува мобилна конекција. Со тоа повеќекратно е зголемена брзината на вчитување на страницата и намалена е потребата од хардверски ресурси (или воопшто компоненти со високи перформанси) на мобилните телефони. Се обидов да извршам оптимизација за пребарувачите (Search Engine Optimization - SEO), со поставување дополнителни мета ознаки. Комбинацијата на пристапот во кодирањето и организирањето на веб локацијата овозможи редуцирано количество неопходен код, поголема контрола при уредувањето на изгледот на страниците, поедноставна промена на елементите (пред се на сликите) т.е. поедноставна одржливост на локацијата итн. 


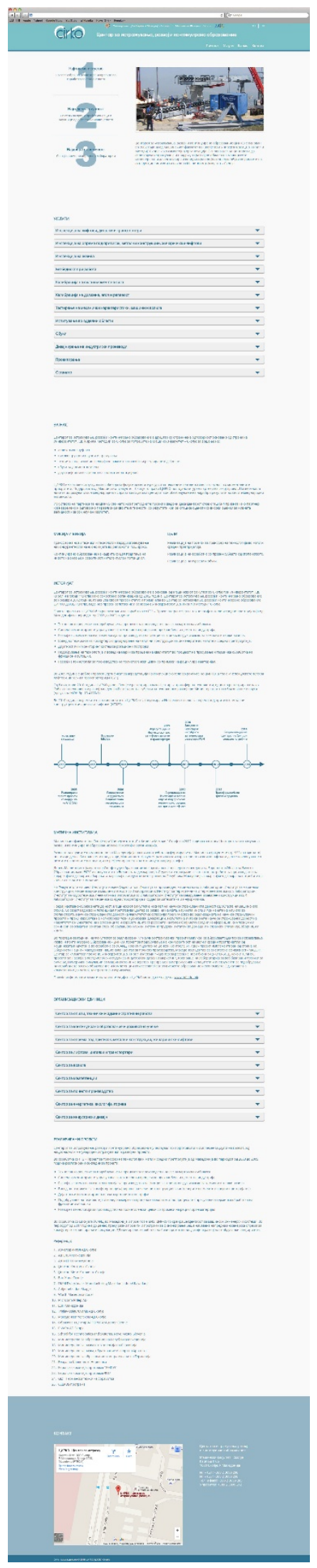

Слика 90 - Веб локација на ЦИРКО ДООЕЛ Скопје (целосен приказ) 

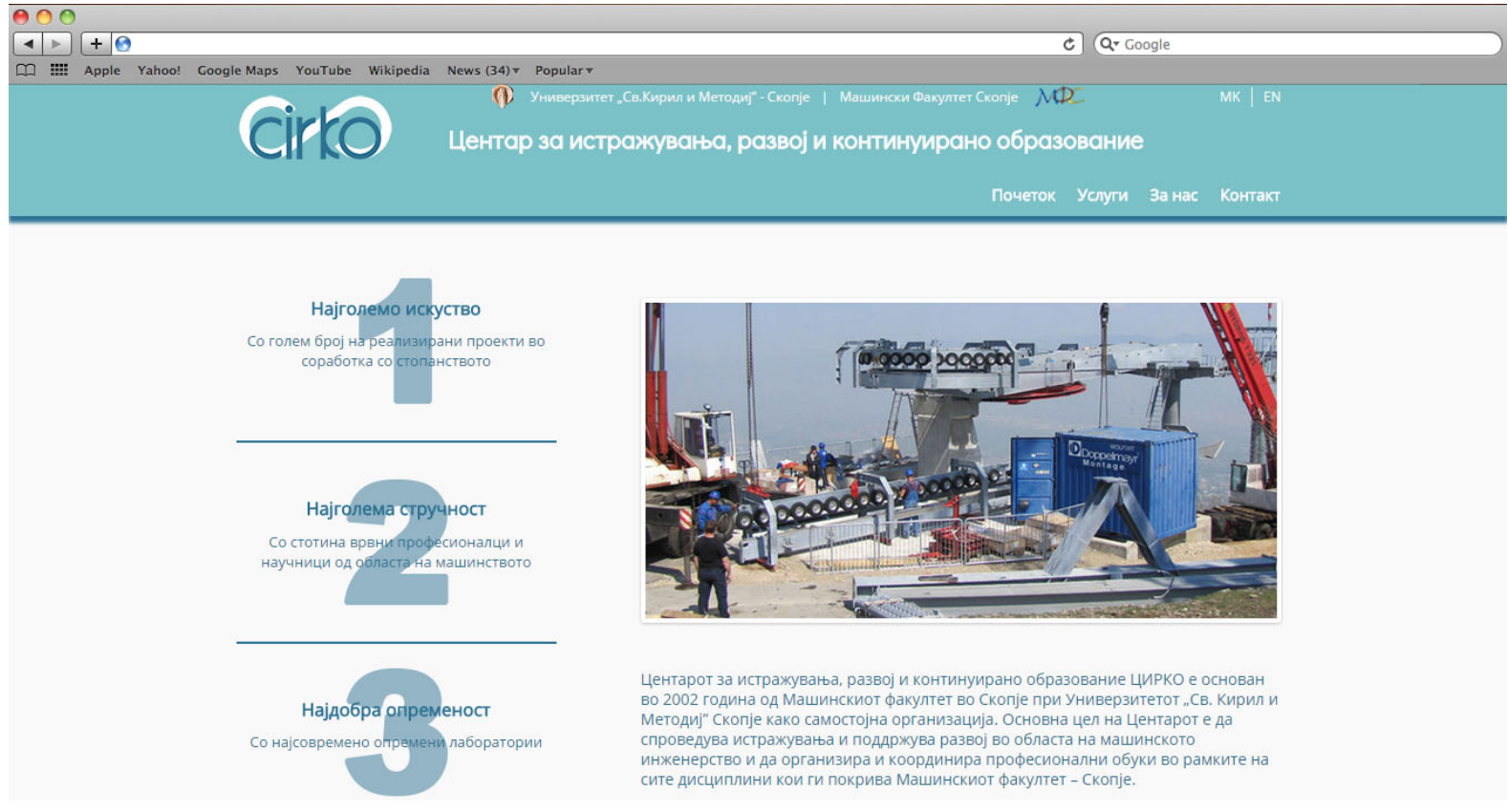

Центарот за истражувања, развој и континуирано образование циРко е основан

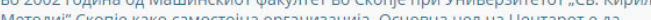
спроведува истражувана и поднржува развој во областа на машинското

инженерство и да организира и координира професионални обуки во рамките на сите дисциплини кои ги покрива Машинскиот факултет - Скопје.

Слика 91 - Почетна секција на веб локацијата на ЦИРКО ДООЕЛ Скопје (приказ до преклоп)

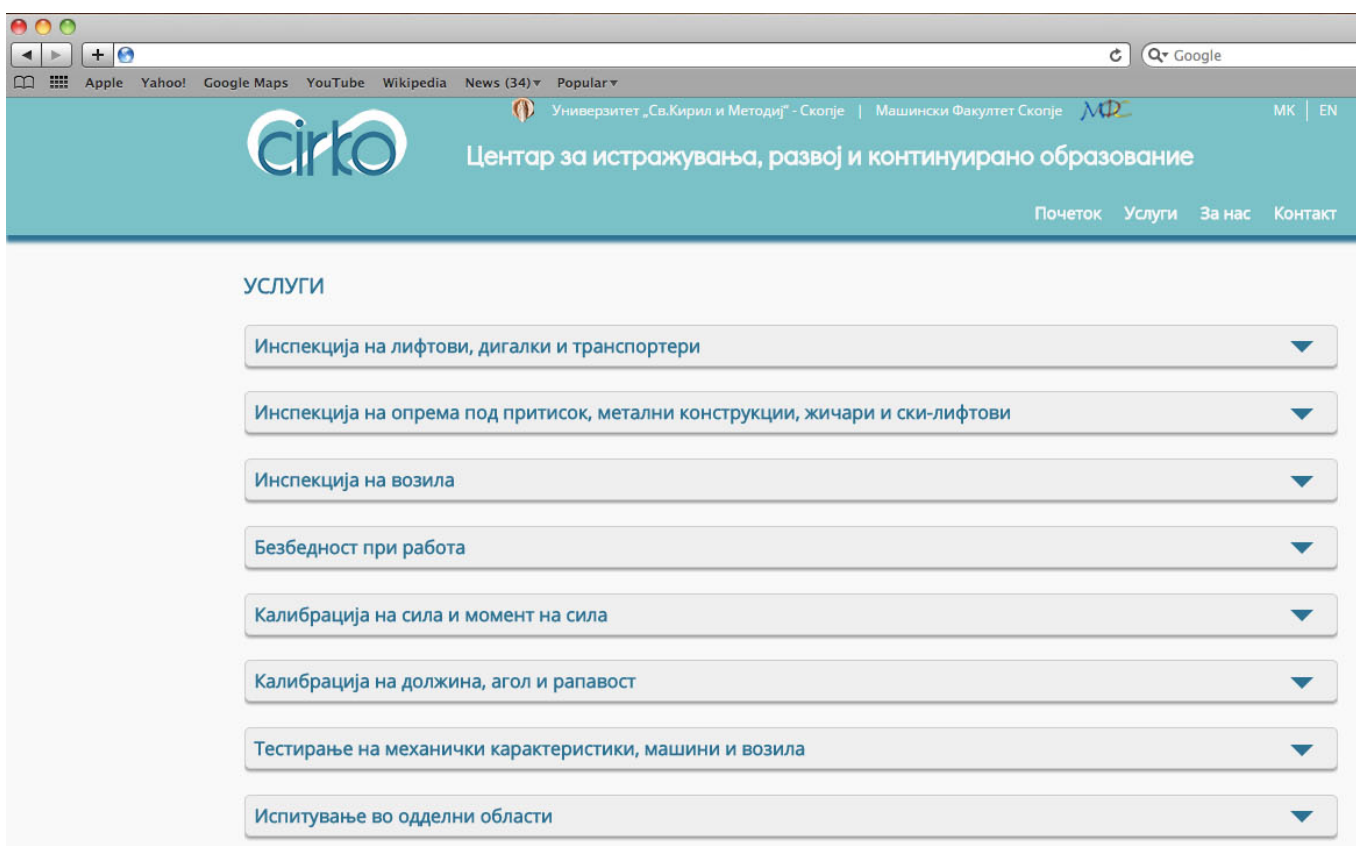

Слика 92 - Секција „Услуги“ на веб локацијата на ЦИРКО ДООЕЛ Скопје (приказ до преклоп) 


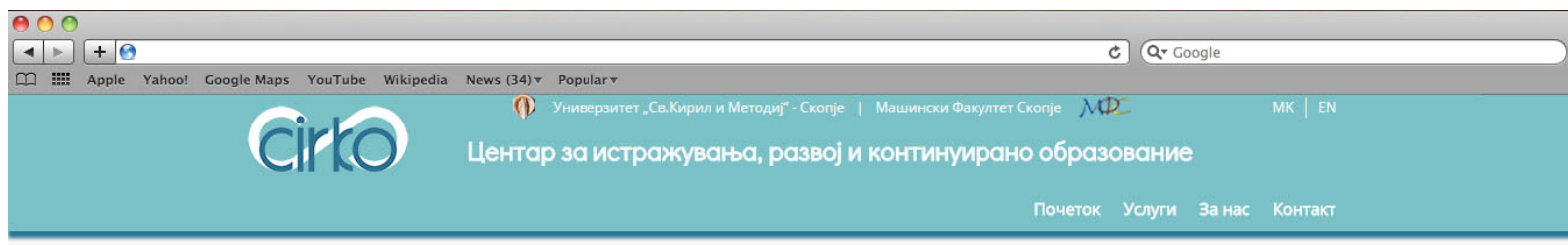

3A HAC

Центарот за истражување, развој и континуирано образование е друштво со ограничена одговорност основано од страна на

Универзитетот „Св. Кирил и Методиі" во Скопје за потребите на Машински факултет - Скопје за вршење на:

- апликативна дејност

- високостручни и научни истражувања

- техничка анализа и инспекција во рамките на законски регулираните дејности

- обуки за доживотно учење

- други дејности во сферата на апликативната дејност

ЦИРКО има агилна структура способна да ги фокусира своите ресурси за тековните активности во согласност со моменталните

приоритети. Поддршката од Машинскиот факултет - Скопје го прави ЦИРКО постојано сигурен партнер на секој проект. Посветеноста на сите истражувачи кон меѓународната соработка го движи центарот кон обезбедување на најдобри резултати во своите мегуународни активности.

Искуството на партнерите на ЦИРКО стекнато низ претходните проекти сведочи дека Центарот отсекогаш бил признат како партнер кој навремено и одговорно ги реализира своите активности, со резултати кои секогаш се оценети со високи оценки за нивната

Слика 93 - Почетен сегмент од секција „За нас“ на веб локацијата на ЦИРКО ДООЕЛ Скопје (приказ до преклоп)
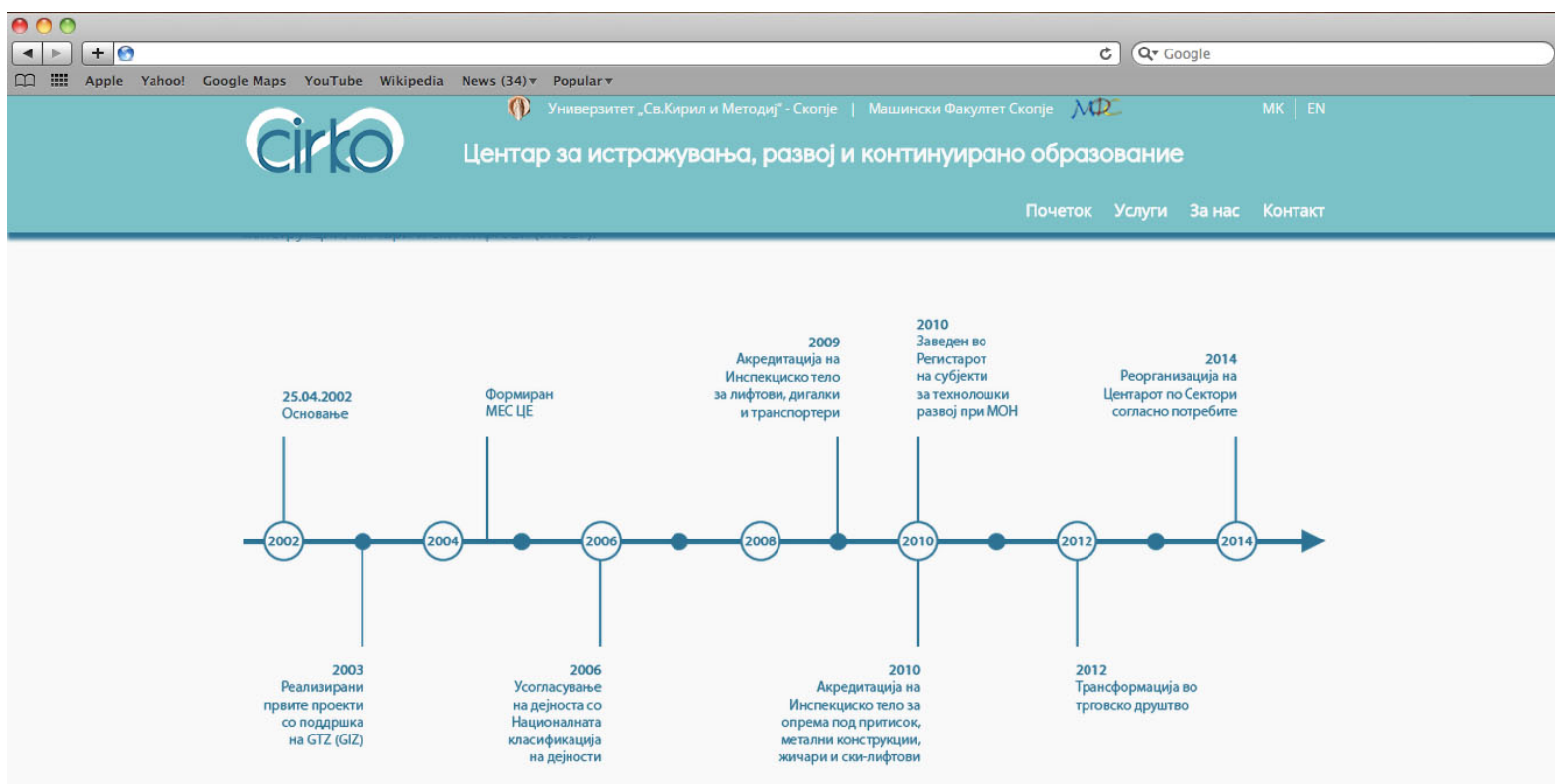

Слика 94 - Сегмент „Историјат“ од секција „За нас“ на веб локацијата на ЦИРКО ДООЕЛ Скопје (приказ до преклоп) 


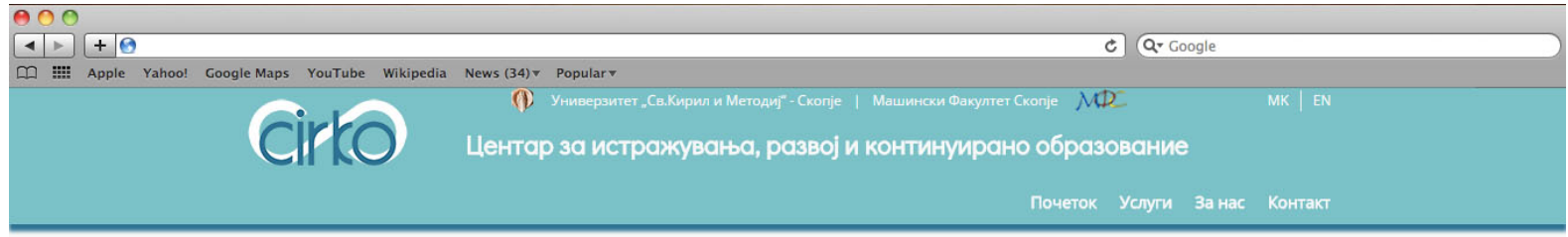

ОРГАНИЗАЦИОНИ ЕДИНИЦИ

$\begin{array}{ll}\text { Сектор за општи, технички и административни работи } & \boldsymbol{\nabla} \\ \text { Сектор за континуирано образование и доживотно учење }\end{array}$

Секторот за континуирано образование и доживотно учење организира семинари, обуки, тренинг, работилници, курсеви за

професионано иконтинуирано образование за потребите на правни и физички, оица, како и за дејноста од останатите сектори во циРКО.

Сектор за опрема под притисок, метални конструкции, жичари и ски-лифтови

Сектор за лифтови, дигалки и транспортери

Сектор за возила

Слика 95 - Сегмент „Организациони единици“ од секција „За нас“ на веб локацијата на ЦИРКО ДООЕЛ Скопје (приказ до преклоп)

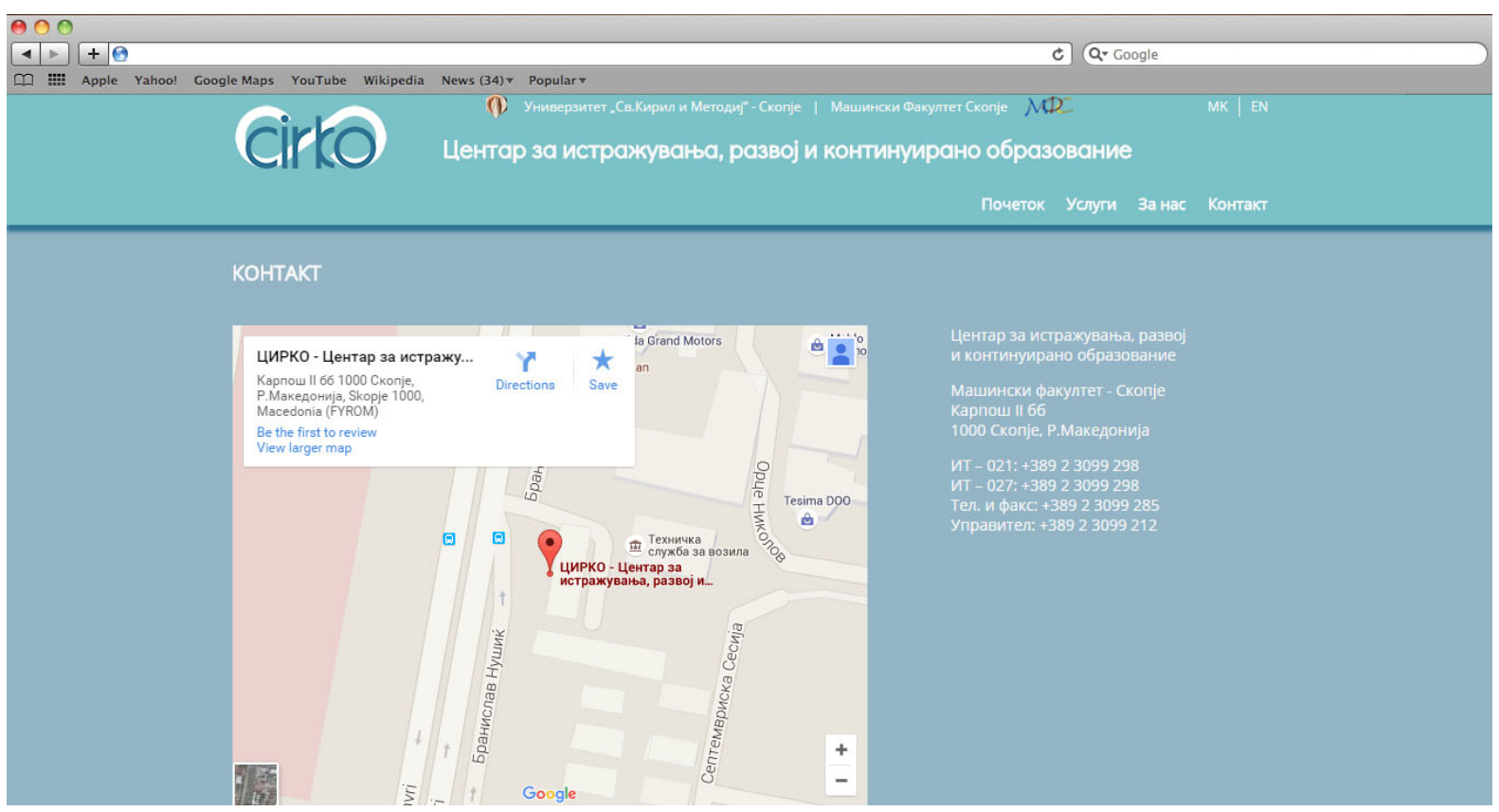

Слика 96 - Секција „Контакт“ на веб локацијата на ЦИРКО ДООЕЛ Скопје (приказ до преклоп) 
Конечно, доколку се разгледа идејата дека во сите случаи не е потребно фокусот да се постави исклучиво на естетиката, туку позначајно е да се подобри функционалноста и организираноста на веб локацијата. Заради тоа што станува збор за само една голема веб страница која ја сочинува целата веб локација, има помалку датотеки кои ја сочинуваат истата. Ова е доста позитивно и тоа од повеќе аспекти, но најзначајна е прегледната организираност на сервер страна, што директно имплицира олеснето натамошно одржување. На крај, особено важна за истакнување е практичноста од примената на прилагодливиот веб дизајн при опслужувањето повеќе уреди истовремено. 


\section{2. Предлог концепти за промотивниот материјал за компанијата ЦИРКО ДООЕЛ СКОпје}

Врз основа на информациите добиени од претходно спроведеното истражување, може несомнено да се заклучи дека во денешно време промоцијата на Интернет просторот е еден од клучните аспекти кој придонесува кон зголемување на препознатливоста и успехот на една компанија. Најпопуларен медиум кој луѓето го користат за да стекнат одредена информација е токму Интернетот. Освен што е најкористен за стекнување одредени потребни информации, Интернетот им остава и најголем впечаток на луѓето во однос на информирање за постоењето на некој производ или услуга. Според ова, слободно може да се заклучи дека најефективно промотивно решение би било рекламирањето на Интернет страниците (пр. преку веб банери). Дополнително, заради тоа што мнозинството од испитаниците се изјасниле дека најголемиот дел од своето време го поминуваат на веб страници кои се со информативни или забавни содржини, сметам дека промотивните активности најнапред треба да бидат насочени кон таквиот тип на веб локации.

При одлучувањето каде да им биде извршена одредена услуга, на најголеми број испитаници пресуден им е квалитетот при извршувањето на услугата. Затоа, при составувањето на содржините наменети за промоција, потребно е да се стави акцент на квалитетот при извршувањето на услугата и компетентноста на кадарот кој ја извршува услугата. Тоа може да се постигне на најразлични начини, но сметам дека е најефективно преку прикажување разни акредитации, сведоштва на клиенти и мултимедијални материјали од завршени проекти. Исто така, поради фактот што дури 89,47\% од испитаниците не се запознаени со поимот „центар за трансфер на технологии“, од исклучителна важност е паралелно со промовирањето да се подигне и свесноста т.е. да се запознаат луѓето со намената на ЦИРКО.

Првиот тип од промотивните решенија се во дигитална форма - анимирани веб банери. Првиот концепт од нив пред сѐ е наменет за поставување од десната страна на веб страницата која е од интерес. Во себе содржи четири сцени, кои се менуваат со поспоро темпо (3000ms), заради количината на текст која ја содржат. За разлика од ова, вториот концепт нема естетски ограничувања во однос на поставувањето, заради 
дизајнот. Исто така, тој е со пократки пораки и се менува со поголема брзина (1500ms), што е дополнително корисно бидејќи содржи повеќе сцени. Кај последното решение прикажувањето на информациите е графички ориентирано. Со ова решение подобро се објаснува улогата на центарот за трансфер на технологии и се изнесуваат акредитациите што помага за зголемување на довербата на идните корисници на услуги.

Вториот тип од промотивните решенија се во печатена форма. Креирав неколку варијанти на вертикален леток со А4 големина, бидејќи летокот овозможува на релативно мал простор да се прикажат доста информации. Кај сите промотивни материјали припадноста кон субјектот кој се промовира, ЦИРКО ДООЕЛ Скопје, дополнително е истакната преку искористените бои. 


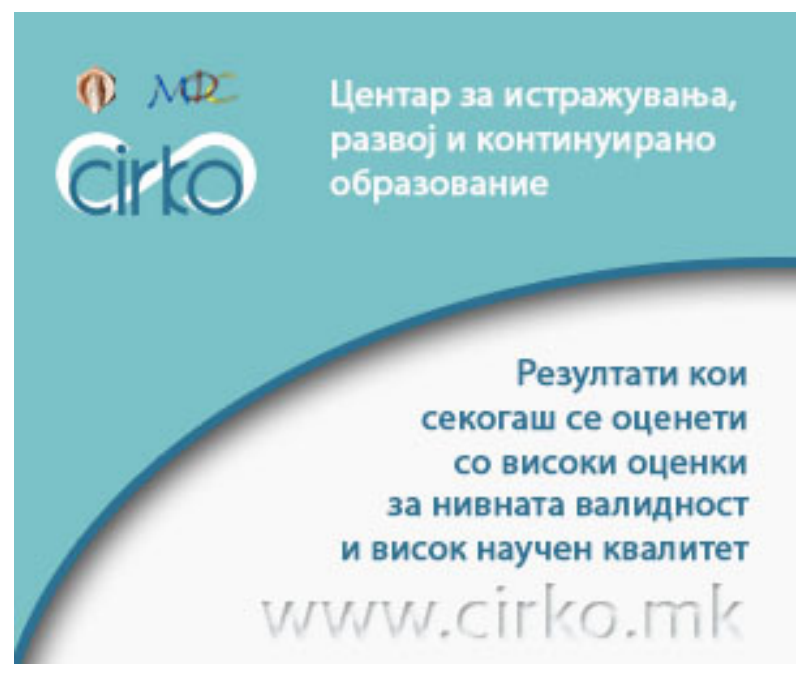

Слика 97 - Сцена од концептот за банер бр.1

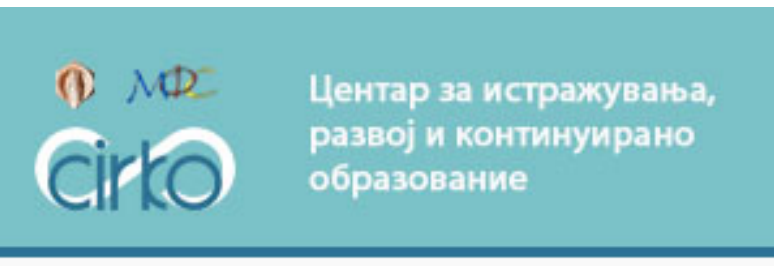

Кога Ви е потребна врвна услуга, ЦИРКО е Вашето решение.

\section{www.cirko.mk}

Слика 98 - Сцена од концептот за банер бр.2

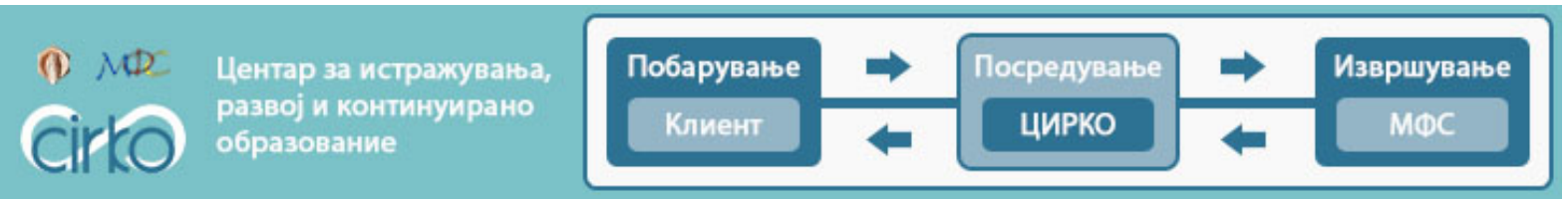

Слика 99 - Сцена од концептот за банер бр.3 


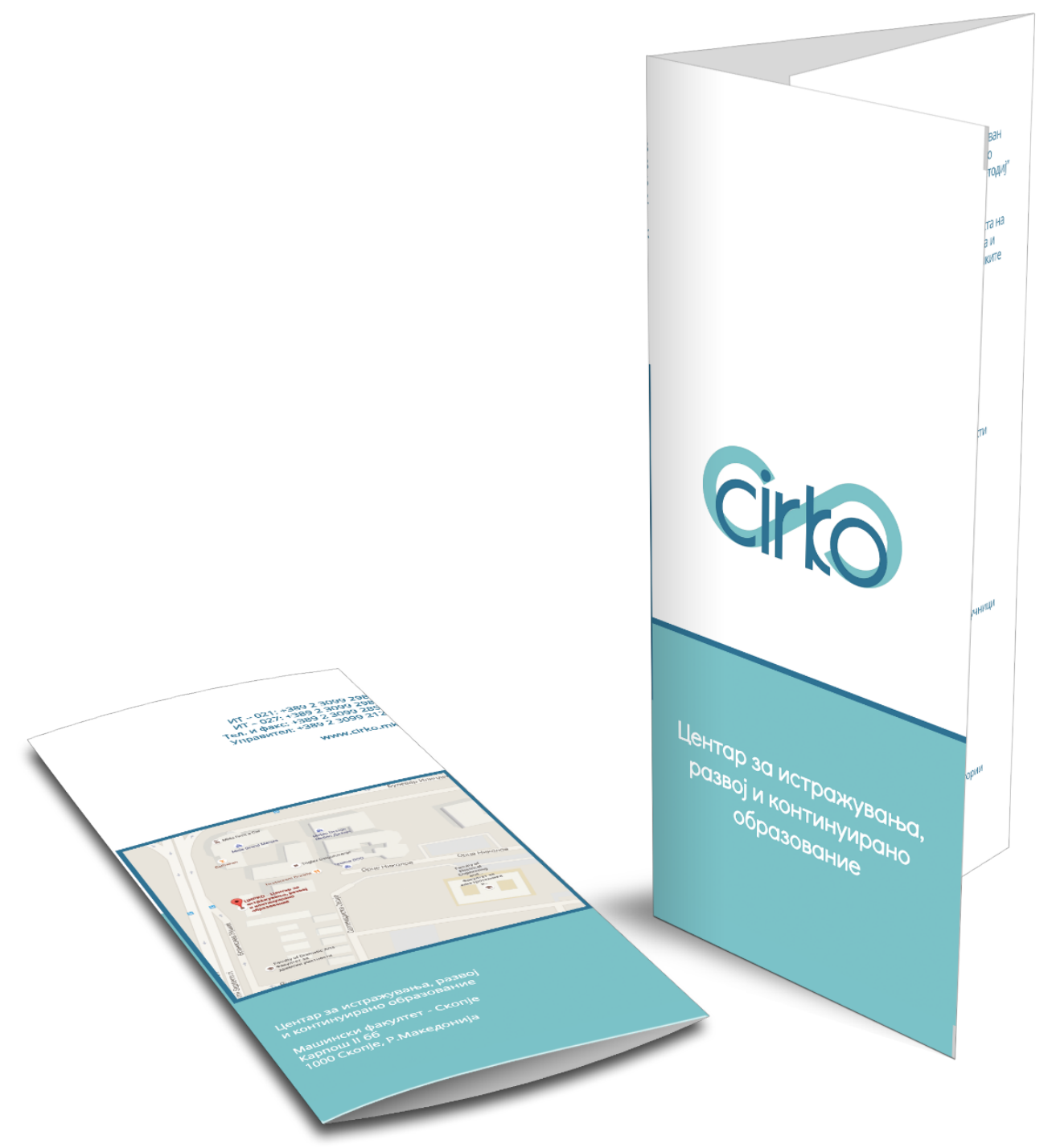

Слика 100 - Варијанта бр.1 за надворешноста на концептот за леток 


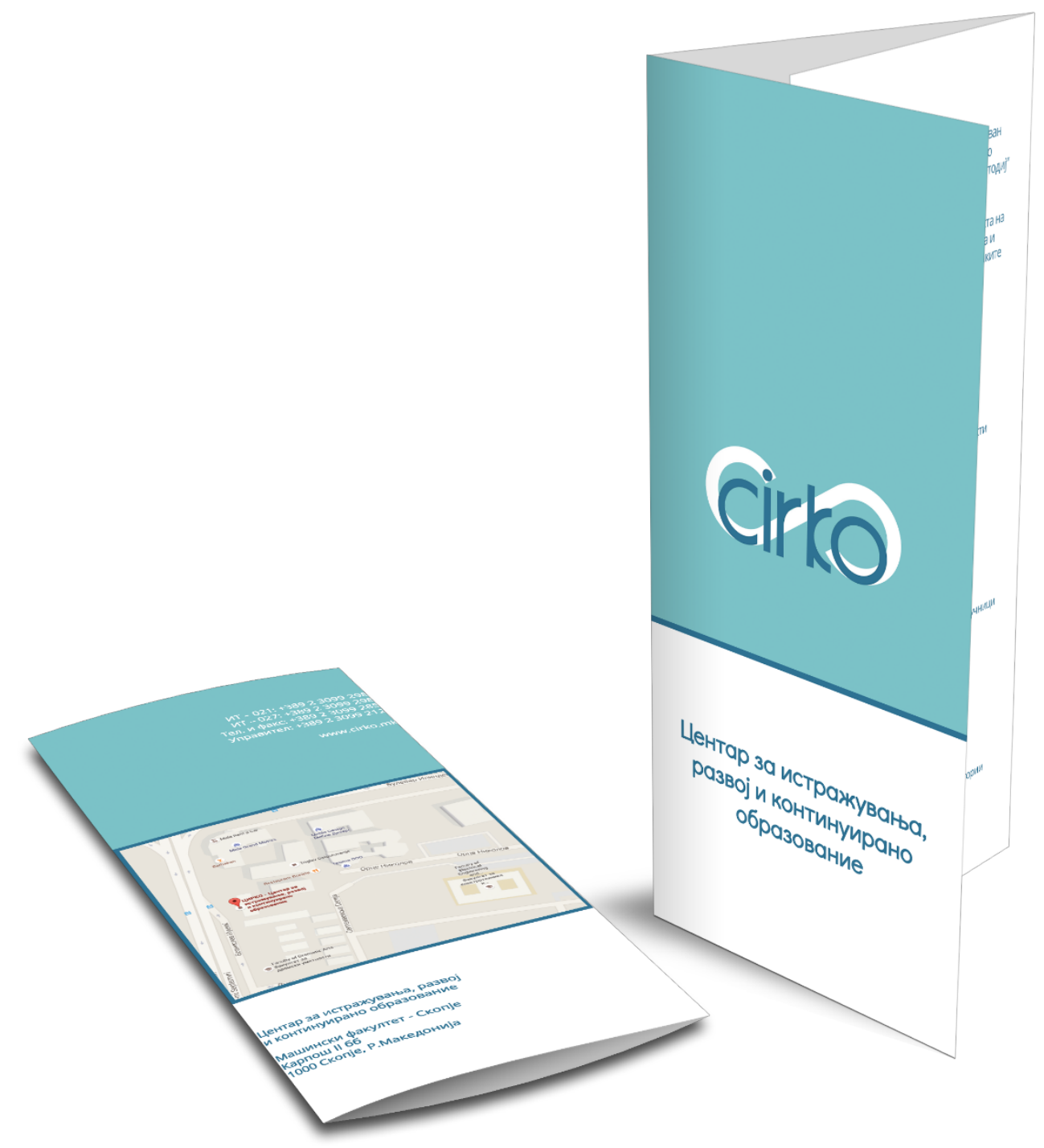

Слика 101 - Варијанта бр.2 за надворешноста на концептот за леток 


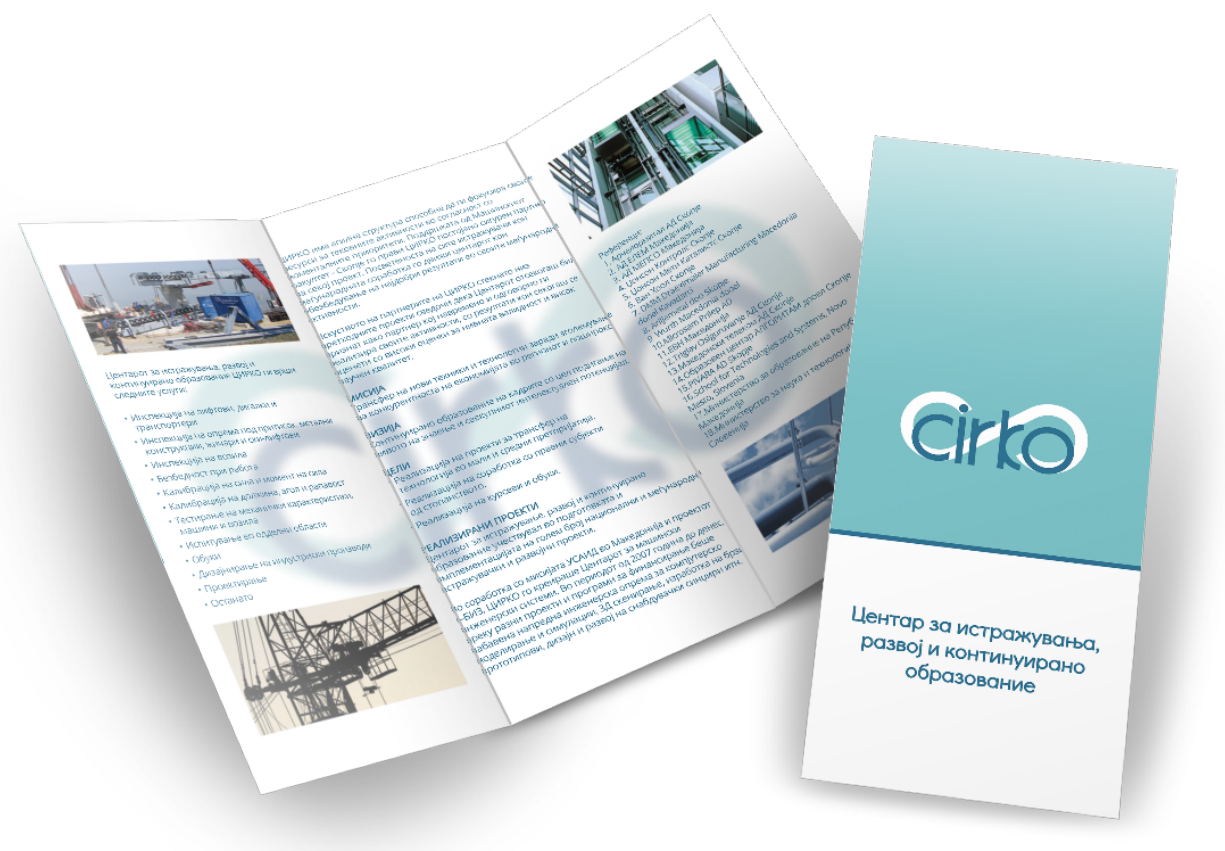

Слика 102 - Варијанта бр.1 за внатрешноста на концептот за леток 


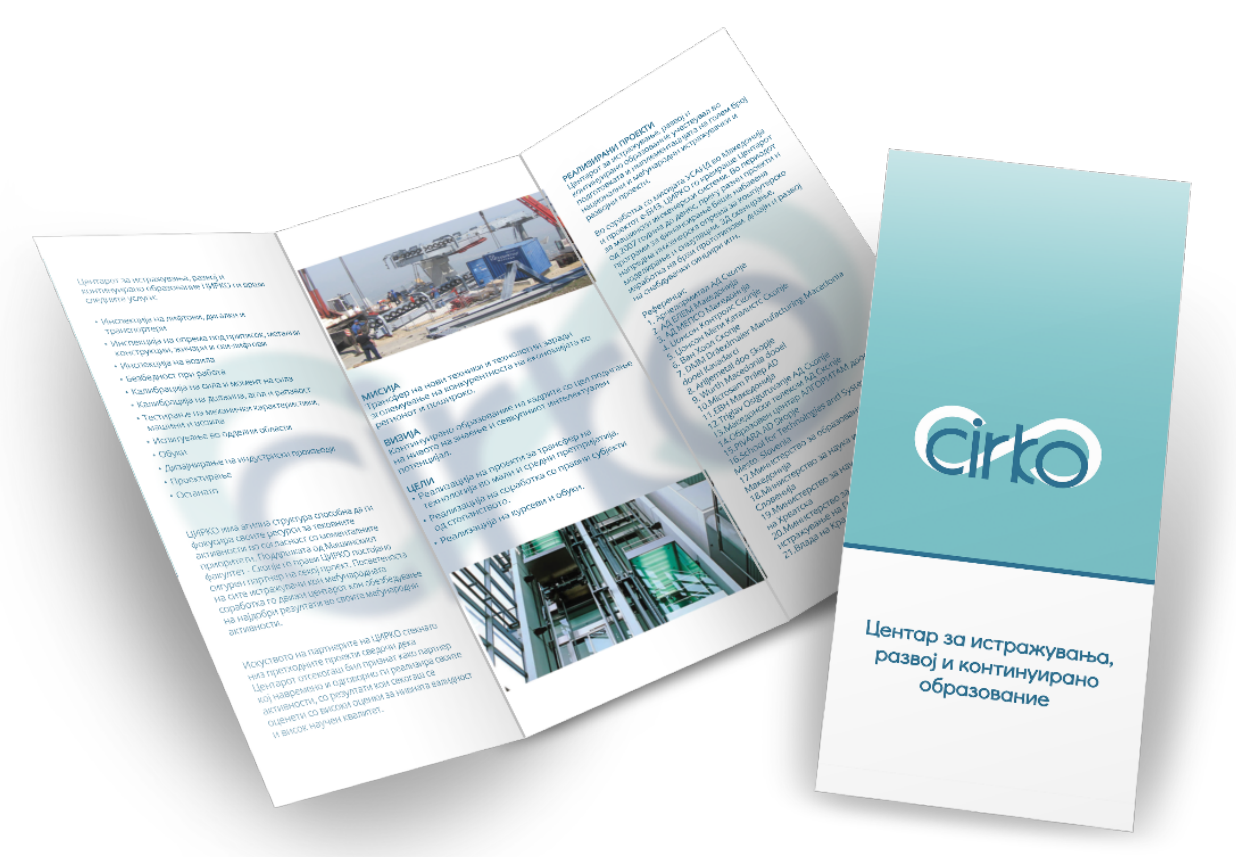

Слика 103 - Варијанта бр.2 за внатрешноста на концептот за леток 


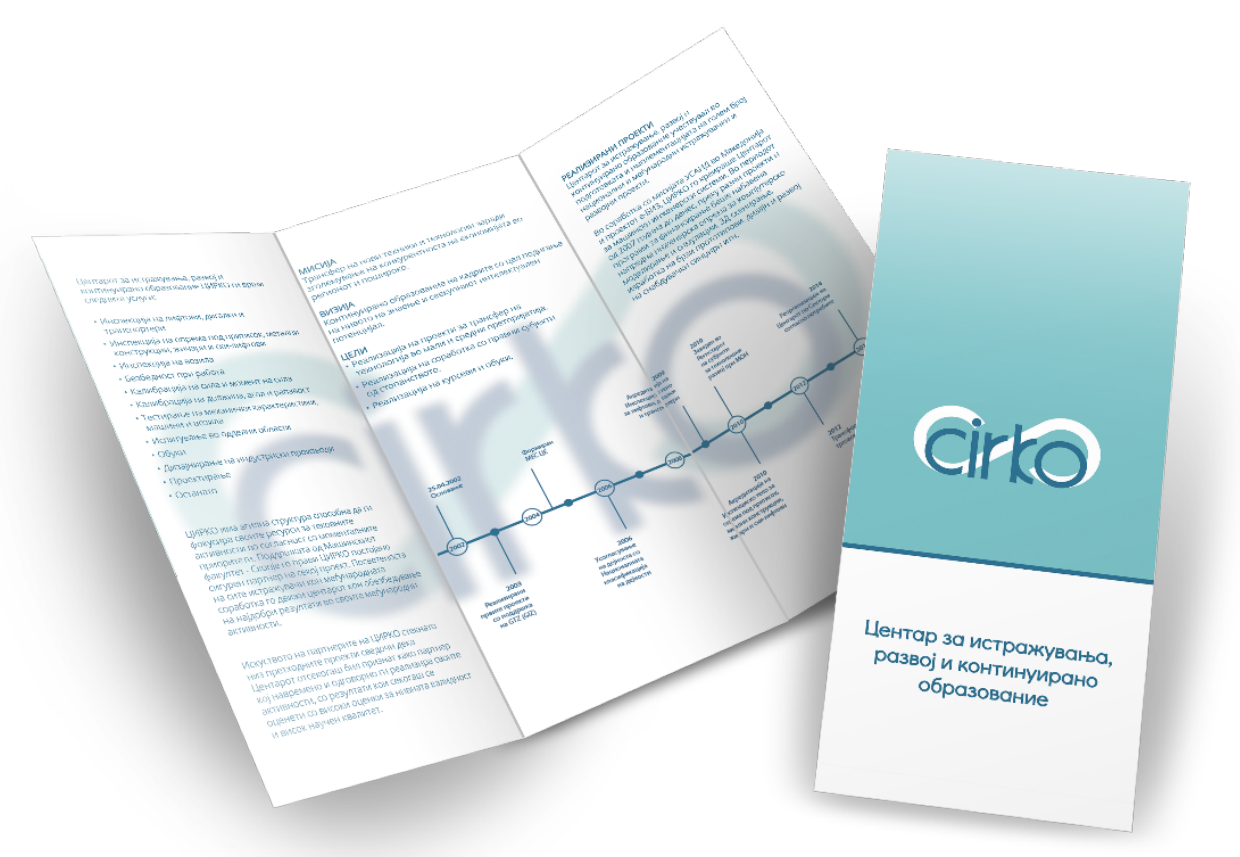

Слика 104 - Варијанта бр.3 за внатрешноста на концептот за леток 


\section{8. Заклучок}

Интернетот, како и сите останати области на информатичката технологија, се развива со доста забрзано темпо и целиот тој развоен процес е далеку од стагнација. Со појавата на прилагодливиот веб дизајн отпочна една нова ера во веб развојот и нормално во самиот веб дизајн. Очекувам дека уште долго време ќе биде имплементиран како стандардна практика, заради практичноста и повеќето предности кои ги нуди, но најмногу заради независноста од типот на уреди (и различните големини на екрани) кои допрва ќе се појавуваат на пазарот. Кога ова ќе се дополни со примена на рамен дизајн, по мое мислење се добива модерна дизајн комбинација која во голем дел не зависи од идните трендови. Тоа овозможува релативно безгрижно опстојување на една веб локација и дава доволен простор за навремена реакција кон нешто радикално ново. Дополнително, правилната примена на горе опишаните ергономски и перцептивни фактори, гарантира (повеќекратно) подобрено корисничко искуство. Понатаму, со помош на спроведените истражувања се доби појасна претстава за тоа какви се навиките на Интернет корисниците, кои се нивните преференции и како можат подобро да се исполнат нивните потреби и барања во однос на веб локацијата. Исто така, се откри и кој е најсоодветниот метод кој треба да се примени за да се создаде ефективна промоција.

Од овие причини, изработената веб локација се очекува да обезбеди подобра посетеност од потенцијалните корисници на услугите на ЦИРКО ДООЕЛ Скопје. Со тоа ќe ce овозможи постигнување на главната цел - подобра национална и интернационална видливост и достапност на компанијата. Квалитетниот естетски и функционален дизајн на веб локацијата, се очекува на потенцијалните коминтенти на услугите на компанијата да им обезбеди лесен и брз пристап до бараните информации.

Целокупните резултати од оваа магистерска тема дадоа придонес во унапредувањето на корпоративниот идентитет на ЦИРКО ДООЕЛ Скопје, со што се подобри нејзината видливост во јавноста и во деловниот свет во областа која ја покрива. 


\section{9. Користена литература}

1. M. MacDonald, Creating a Website: The Missing Manual, Third Edition, O'Reilly Media, Inc., Sebastopol, CA, USA, 2011.

2. M. Boulton, A Practical Guide to Designing for the Web, Mark Boulton Design Ltd., Penarth, UK, 2009.

3. J. Beaird, The Principles of Beautiful Web Design, SitePoint Pty. Ltd., Australia, 2007.

4. J. Johnson, Designing with the mind in mind, Morgan Kaufmann Publishers, Burlington, MA, USA, 2010.

5. G. Salvendy, Handbook of Human Factors and Ergonomics, Fourth Edition, John Wiley \& Sons, Inc., Hoboken, NJ, USA, 2012.

6. C. D. Wickens, J. Lee, Y. D. Liu, S. Gordon-Becker, Introduction to Human Factors Engineering, Second Edition, Prentice-Hall, Upper Saddle River, NJ, USA, 2004.

7. H. Liao, Y. Guo, A. Savoy, G. Salvendy, Content Preparation Guidelines for the Web and Information Appliances: Cross-Cultural Comparisons, CRC Press, Boca Raton, FL, USA, 2010.

8. H. Loranger, J. Nielsen, Prioritizing Web Usability, New Riders Press, Berkeley, CA, USA, 2006.

9. J. Nielsen, K. Pernice, Eyetracking web usability, New Riders Press, Berkeley, CA, USA, 2010.

10. S. Weinschenk, 100 Things Every Designer Needs to Know About People, New Riders Press, Berkeley, CA, USA, 2011.

11. E. Marcotte, Responsive Web Design, A Book Apart, New York, New York, 2011.

12. Y. Dong, K. Lee, A Cross-Cultural Comparative Study of Users' Perceptions of a Webpage, International Journal of Design, Vol.2, No.2, 2008.

13. M. W. Newman, J. A. Landay, Sitemaps, Storyboards, and Specifications: A Sketch of Web Site Design Practice, Proceedings of the Symposium on Designing Interactive Systems 2000, Association for Computing Machinery

14. Study: 55 Percent Of Mobile-Search Driven Conversions Happen In One Hour Or Less http://searchengineland.com/study-55-percent-of-mobile-search-drivenconversions-happen-in-one-hour-or-less-151432 
15. Why Google Recommends Responsive Web Design by Cameron Soojian (17.02.2015) http://www.business2community.com/seo/google-recommends-responsive-webdesign-01159920

16. Creating Web Designs that Change to Meet the Needs of the User by Jennifer Kyrnin http://webdesign.about.com/od/layout/a/responsive-design.htm

17. Mobile First Design https://codemyviews.com/blog/mobilefirst

18. The Gutenberg Diagram in Web Design by Mário R. Andrade (09.06.2013) https://medium.com/user-experience-3/the-gutenberg-diagram-in-web-design$\underline{\mathrm{e} 5347 \mathrm{c} 172627}$

19. How Long Do Users Stay on Web Pages by Jakob Nielsen (12.09.2011) http://www.nngroup.com/articles/how-long-do-users-stay-on-web-pages/

20. Typographic Design Patterns and Best Practices by Michael Martin (20.08.2009) http://www.smashingmagazine.com/2009/08/20/typographic-design-survey-bestpractices-from-the-best-blogs/

21. Touch Target Sizes by Luke Wroblewski (04.05.2010) http://www.lukew.com/ff/entry.asp?1085

22. World Internet Users Statistics http://www.internetworldstats.com/stats.htm

23. StatCounter Global Stats http://gs.statcounter.com/

24. Државен завод за статистика - Информатичко општество http://www.stat.gov.mk/OblastOpsto.aspx?id=27 